\begin{tabular}{|l|l|l|}
\hline ENGINEERING CHANGE NOTICE & Pago 1 of 2 & 657431 \\
\hline
\end{tabular}

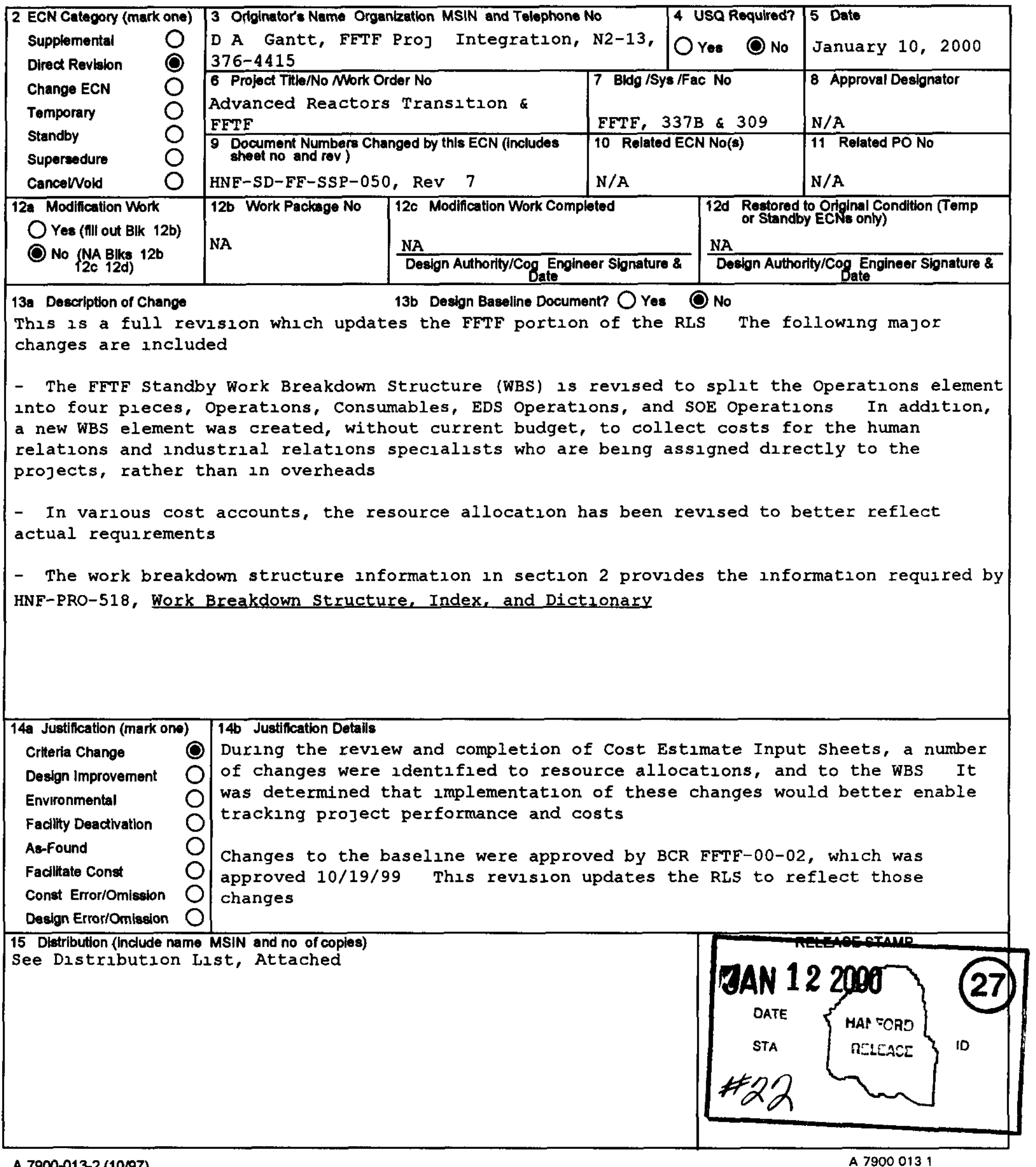


ENGINEERING CHANGE NOTICE

16 Design Verifcation Required

O Yes

No
17 Cost Impact

ENGINEERING

Additional $\mathrm{O} s$

Savings $\bigcirc$ s \begin{tabular}{l|l} 
Page 2 of 2 & 2 \\
\hline
\end{tabular}

18 Schedule Impact (days)

Improvement $O$

Delay

19 Change Impact Review Indicate the related documents (other than the engineering documents identified on Side 1) that will be affected by the change described in Block 13 Enter the afiected document number in Block 20

$\begin{array}{llll}\text { SDDIDD } & \square & \text { Seismic/Stress Analysis } & \square \\ \text { Functional Design Criteria } & \square & \text { Stress/Design Report } & \square \\ \text { Operating Specification } & \square & \text { Interface Control Drawing } & \square \\ \text { Criticality Specification } & \square & \text { Callbration Procedure } \\ \text { Conceptual Design Report } & \square & \text { Installation Procedure } & \square \\ \text { Equipment Spec } & \square & \text { Maintenance Procedure } & \square \\ \text { Const Spec } & \square & \text { Engineering Procedure } & \square \\ \text { Procurement Spec } & \square & \text { Operating Instruction } & \square \\ \text { Vendor Iniormation } & \square & \text { Operating Procedure } & \square \\ \text { OM Manual } & \square & \text { Operational Safety Requirement } & \square \\ \text { FSAR/SAR } & \square & \text { IEFD Drawing } & \square \\ \text { Safety Equipment List } & \square & \text { Cell Arrangement Drawing } & \square \\ \text { Radiation Work Permit } & \square & \text { Essential Material Specification } & \square \\ \text { Environmental Impact Statement } & \square & \text { Fac Proc Samp Schedule } & \square \\ \text { Environmental Report } & \square & \text { Inspection Plan } \\ \text { Environmental Permit } & \square & \text { Inventory Adjustment Request } & \square\end{array}$

Tank Calibration Manual Health Physics Procedure Spares Multiple Unit Listing Test Procedures/Specification Component Index ASME Coded Item Human Factor Consideration Computer Soltware

Electric Circult Schedule ICRS Procedure Process Control Manual/Plan Process Flow Chart Purchase Requisition Tickler File

Other Affected Documents (NOTE Documents listed bolow will not be revised by this ECN) Signatures below indicate that the signing organization has been notified of other affected documents listed below

None

21 Approvals

\section{Signature}

Date

Design Authority

$\operatorname{Cog}$ Eng $D \quad A \quad$ Gantt QA

Safety

Environ

Other

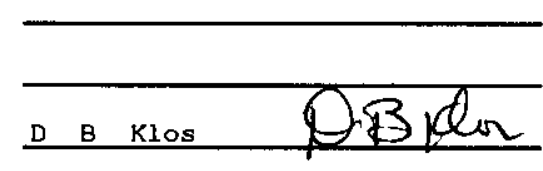

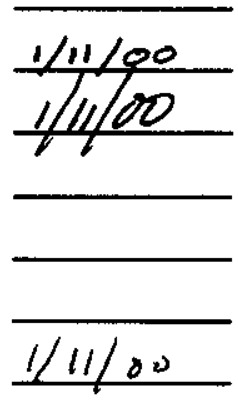

Design Agent

PE

QA

Safety

Design

Environ

Other

\section{DEPARTMENT OF ENERGY}

Signature or a Control Number that tracks the Approval Signature

\section{ADDITIONAL}




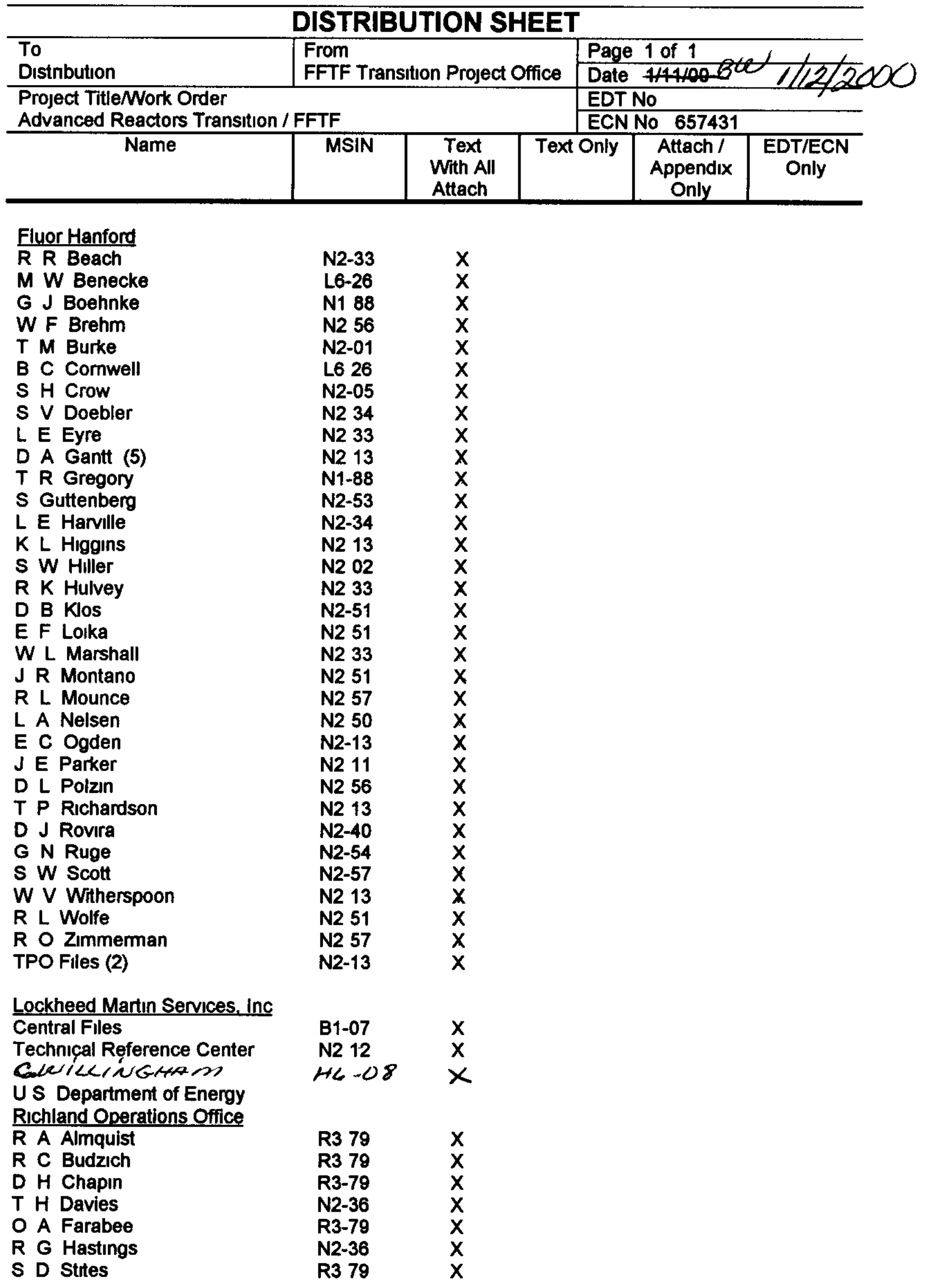




\title{
ADVANCED REACTORS TRANSITION PROGRAM RESOURCE LOADED SCHEDULE
}

\author{
D $\mathbf{A}$ Gantt
}

Fluor Hanford

Richland WA 99352

U S Department of Energy Contract DE-AC06-96RL13200

$\begin{array}{llll}\text { EDT/ECN } & \text { ECN } 657431 & \text { UC N/A } & \\ \text { Org Code } & \text { 1C400 } & \text { Charge Code } & 101559 \\ \text { B\&R Code } & \text { AF79 } & \text { Total Pages } & 200\end{array}$

Key Words

Resource, Loaded, Schedule, FFTF, RLS, Legacles, PRTR

Abstract The Advanced Reactors Transition (ART) Resource Loaded Schedule (RLS) provides a cost and schedule baseline for managing the project elements within the ART Program The Fast Flux Test Facility (FFTF) activities are delineated through the end of FY 2000, assuming continued standby The Nuclear Energy (NE) Legacies and Plutonium Recycle Test Reactor (PRTR) activites are delineated through the end of the deactivation process This revision reflects the 19 Oct 1999 baseline

TRADEMARK DISCLAIMER Reference herein to any specific commercial product process or service by trade name trademark manufacturer or otherwise does not necessarily constitute or imply the endorsement recommendation or favoring by the United States Government or any agency thereof or lts contractors or subcontractors

Printed in the United States of America To obtain copies of this document contact Document Control Services P O Box 950 Mailstop H6-08 Richland WA 99352 Phone (509) 3722420 Fax (509) 376-4989

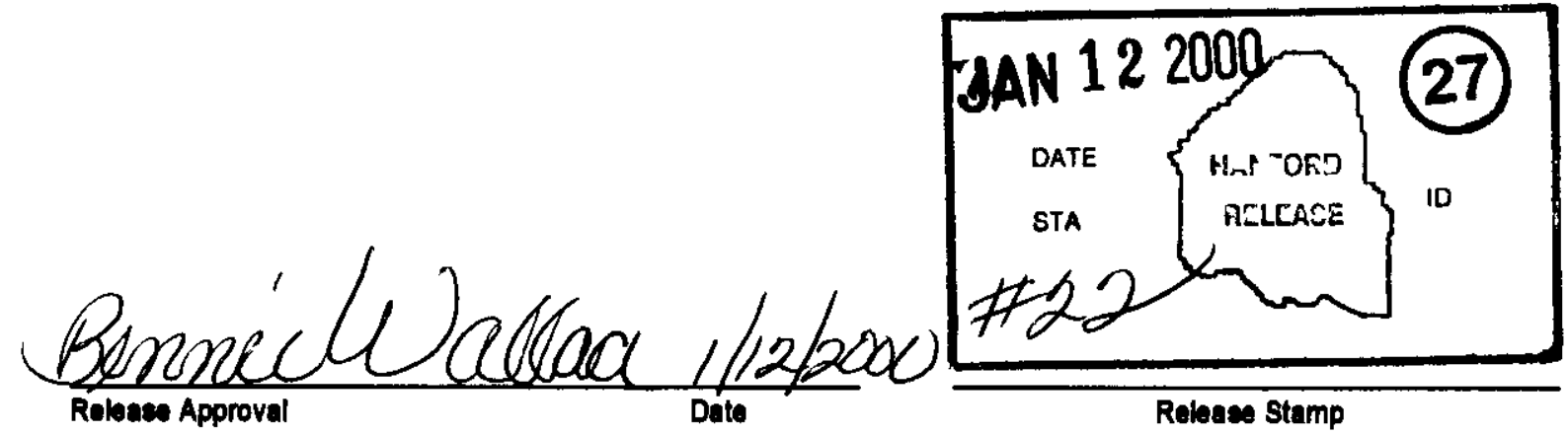


(2) Title

Advanced Reactors Transition Program Resource Loaded Schedule

\section{Change Control Record}

(3) Revision

( 17$)$

1

2

3

4

5

6

7

8

(7)
(4) Description of Change Replace Add and Delete Pages

Engineerıng Data Transmuttal \# 608179

Total Revision of Document per Engineering Change Notice (ECN) \#616242

Total Revision per ECN 624688

Total Revision per ECN 637801

Total Revision per ECN 642518

Total Revision per ECN 644777

Total Revision per ECN 652201

Total Revision per ECN 652210

Revised FFTF Work Breakdown structure and resource allocations ECN 657431
Authorized for Release

\begin{tabular}{l|ll} 
(5) Cog Engr & (6) Cog Mgr Date
\end{tabular}

TR Gregory $\quad$ R $K$ Hulvey

\begin{tabular}{l|ll} 
TR Gregory & $R$ & $K$ \\
\end{tabular}

$10 / 31 / 94$

\begin{tabular}{l|ll} 
SH Crow & R $K$ Hulvey
\end{tabular} $10 / 30 / 95$

\begin{tabular}{l|l} 
DA Gantt & R $K$ Hulvey
\end{tabular}

$9 / 27 / 96$

\begin{tabular}{l|l} 
RR Beach & R K Hulvey
\end{tabular}

\begin{tabular}{l|lrr} 
& & \multicolumn{6}{c}{$6 / 24 / 97$} \\
WW Bowen & $R$ & $K$ & $\begin{array}{r}\text { Hulvey } \\
10 / 31 / 97\end{array}$
\end{tabular}

\begin{tabular}{l|ll} 
DA Gantt & $R \quad K \quad$ Hulvey
\end{tabular}

$1 / 13 / 99$

\begin{tabular}{l|ll} 
DA Gantt & R $K$ Hulvey
\end{tabular}

DA Gantt

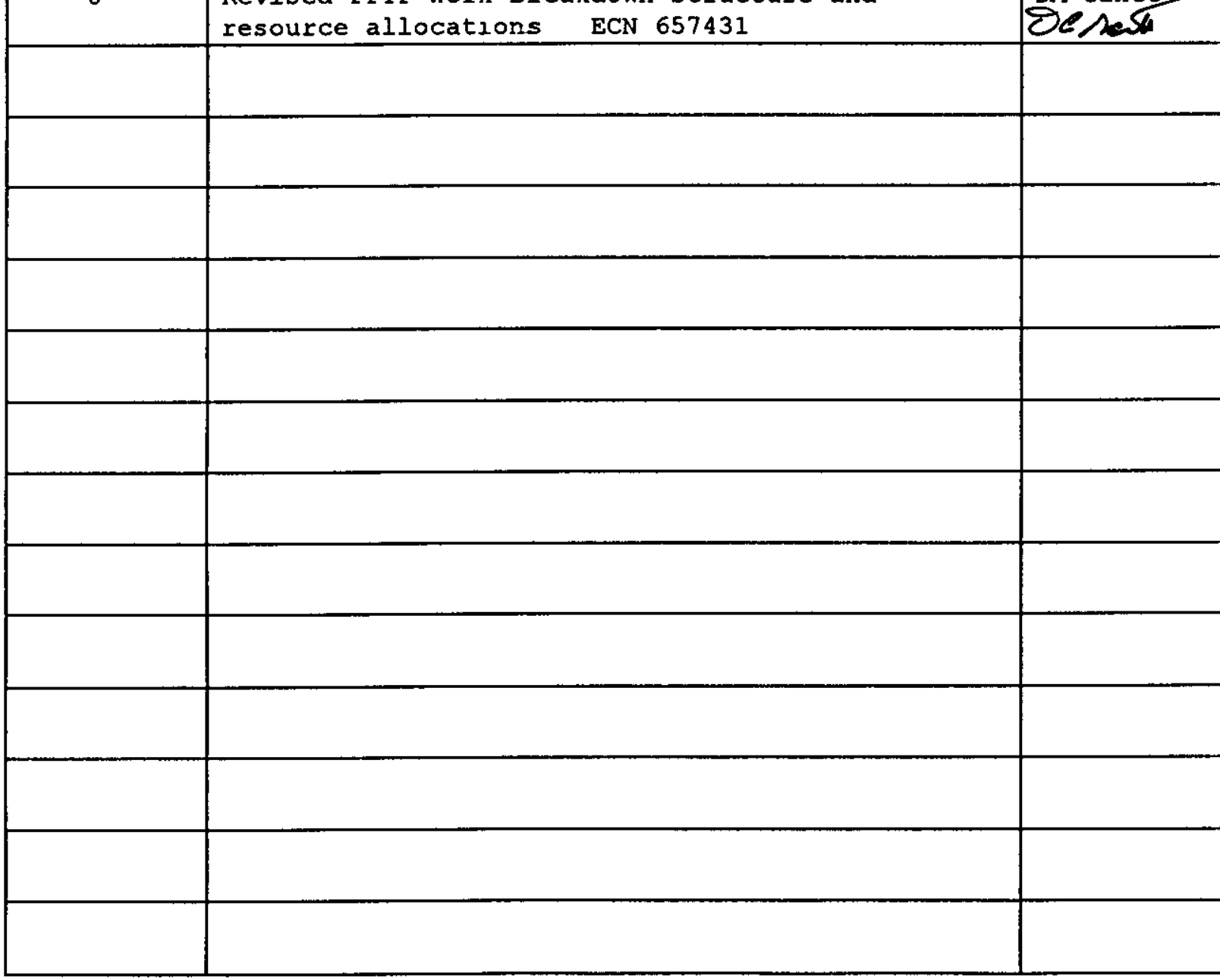




\section{RELEASE AUTHORIZATION}

\section{Document}

Number HNF-SD-FF-SSP-050 REV 8

\section{Document}

Title

ADVANCED REACTORS TRANSITION PROGRAM RESOURCE LOADED

SCHEDULE

This document, reviewed in accordance with

DOE Order 241 1, "Scientific and Technical

Information Management," and DOE G 241 1-1,

"Guide to the Management of Scientific and

Technical Information," does not contain

classified or sensitıve unclassified information

and is

\section{APPROVED FOR PUBLIC RELEASE}
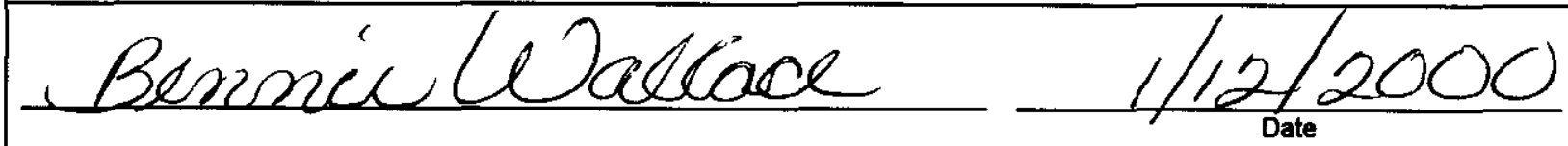

Lockheed Martin Services, Inc

Document Control / Information Clearance

Reviewed for Applied Technology Business Sensitive Classified Copyrighted, Export Controlled Patent Personal/Private Proprietary Protected CRADA Yrademark Unclassified Controlled Nuclear Information

LEGAL DISCLAIMER This report was prepared as an account of work sponsored by an agency of the United States Government Nelther the Unlted States Government nor any agency thereof not any of their employees nor any of their contractors subcontractors or their employees makes any warranty express or implied or assumes any legal llability or responsibility for the accuracy completeness, or any third party $s$ use or the results of such use of any information, apparatus product or process disclosed or represents that its use would not infringe privately owned rights Reference herein to any specific commerclal product process or service by trade name trademark manufacturer or otherwise does not necessarily constitute or imply its endorsement recommendation or favoring by the United States Government or any agency thereof of its contractors or subcontractors The views and opinions of authors expressed herein do not necessarily state or reflect those of the United States Government or any agency thereof This report has been reproduced from the best available copy Printed in the United States of America 


\section{TABLE OF CONTENTS}

10 EXECUTIVE SUMMARY 1

11 Mission 1

12 Scope 1

13 Work Breakdown Structure $\quad 2$

14 Schedule 2

15 Cost Summary 2

20 TECHNICAL BASELINE

21 Mission 11

22 Scope 11

23 Assumptions $\quad 12$

24 Work Breakdown Structure 13

30 SCHEDULE BASELINE

31 Master Schedule $\quad 69$

32 Milestones $\quad 69$

40 COSTS $\quad 73$

41 Cost Detall $\quad 73$

42 Cost Baselıne $\quad 73$

43 Budget Authority $\quad 73$

44 Planned Staffing $\quad 73$

50 RESOURCE LOADED SCHEDULE BASIS $\quad 79$

51 Methodology and Historical Basis $\quad 79$

52 Basıc Data and Estımate Backup Sheets $\quad 79$

53 Cost Estımate Reviews $\quad 80$

60 BASELINE CHANGE CONTROL

70 REFERENCES $\quad 83$

A SCHEDULES $\quad 85$

B USAGE AND COSTS 
FIGURES

11 Advanced Reactors Transition (RL TP11) Work Breakdown Structure 3

12 FFTF Work Breakdown Structure 4

13 NE Legacies Summary Schedule $\quad 5$

14 PRTR/309 Bullding Summary Schedule $\quad 6$

15 FFTF Standby Summary Schedule $\quad 7$

16 RL Level Milestones $\quad 8$

21 Advanced Reactors Transition (RL TP11) Work Breakdown Structure 14

22 FFTF Work Breakdown Structure $\quad 15$

\section{TABLES}

11 ART (RL-TP11) Lifecycle Costs by Fiscal Year 9

12 FFTF Costs by Fiscal Year $\quad 10$

21 Responsibility Assignment Matrxx $\quad 67$

31 Active Milestones $\quad 70$

32 TPA Milestones Pending Change Request Approval $\quad 71$

41 ART (RL TP11) Lifecycle Costs by Fiscal Year $\quad 74$

42 FFTF Costs by Fiscal Year $\quad 75$

43 PHMC Fee Allocation $\quad 75$

44 FY 2000 Cost Baselıne $\quad 76$

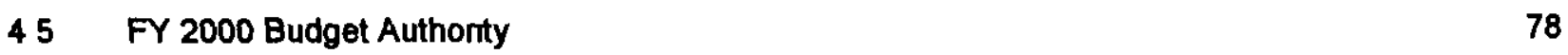




\section{EXECUTIVE SUMMARY}

\section{Mission}

The Advanced Reactors Transition (ART) Program has two missions One funded by DOE EM Is to transition assigned surplus facilities to a safe and compliant low-cost stable deactivated condition (requinng mıımal survellance and maıntenance) pending eventual reuse or D\&D Facilities to be transitioned include the 309 Building / Plutonium Recycle Test Reactor (PRTR) and Nuclear Energy Legacy facilities This mission is funded through the Environmental Management (EM) Project Baselıne Summary (PBS) RL-TP11 "Advanced Reactors Transition "

The second mission funded through budget requests submitted to the Office of Nuclear Energy Science and Technology (DOE-NE) is maintaining the Fast Flux Test Facility (FFTF) the Fuels and Matenais Examınation Facility (FMEF) and affiliated 400 Area buldings in a safe and compliant standby condition This mission is to preserve the condition of the plant hardware software and personnel in a manner not to preclude a plant restart

\section{Scope}

This revision of the Resource Loaded Schedule (RLS) is based upon the technical scope in the latest revision of the following project and management plans

$$
\begin{aligned}
& \text { Fast Flux Test Facility Standby Plan (Reference 1) } \\
& \text { Hanford Site Sodium Management Plan (Reference 2) } \\
& 309 \text { Building Transition Plan (Reference 4) }
\end{aligned}
$$

The technical scope cost and schedule baseline is also in agreement with the concurrent revision to the ART Fiscal Year (FY) 2000 Multr-Year Work Plan (MVWP) which is avallable in an electronic version (only) on the Hanford Local Area Network within the Hanford Data Integrator (HANDI) application

\section{Life Cycle}

Transitioning the 309 Building to a safe and compliant low-cost stable deactivated condition requires that the faclity be charactenzed through survey sampling and analysis hazardous matenals must be removed or stabilized a structurally sound building envelop must be established and the conditions must be documented to support future decontamination and disposal This work will be accomplished on an area by area basis At the conclusion of this process the building will be turned over to the environmental restoration contractor

Deactivation of the Nuclear Energy Legacy facilities requires that the alkali metals sodium and sodium-potassium (NaK) alloy be removed from the various test and development systems which were located around the site At the end of FY 1999 all of this sodium and NaK had been removed and the test systems deactivated except for those in the 300 Area 337 Bulding High Bay

The Fast Flux Test Facility is in standby pending a decision on potential future mission options In this state maintenance will be performed to ensure the availability of the facility to accomplish any assigned mission including shutdown in a tımely cost effective manner

\section{Execution Year}

All assigned facilities will be maintained in a safe and compliant state through appropnate survellance and maintenance activities 
The 309 Building deactivation activities in FY 2000 will be limited by funding constraints The principal activity will be to begin the clean out of the Fuel Transfer Pit

In the NE Legacy facilities cleaning of the two tanks previously removed from 221-T will continue using the moist nitrogen vapor process

The FFTF standby activities will focus on the following

- Maintaining the "health of the facility through the performance of appropnate preventive and corrective maintenance actions

- Preparing the redesign of the Solid Waste Cask to satısfy all applicable fuel handling requirements

- Acceptance testıng of the Closed Loop Ex-vessel Machıne (CLEM) new computer control system

- Installing the upgraded control system for the IEM Cell sodium removal system

- Venfying the capability to implement Y2K contingency plans

- Providıng technical support for the Programmatıc Environmental Impact Statement process

\section{Work Breakdown Structure}

The two missions have independent work breakdown structures as shown in Figures 11 and 12

\section{Schedule}

The detalled schedules are shown in Appendix A However pictonal summanes of the subproject schedules are included in this section

\section{NE Legacies}

The NE Legacies schedule is depicted in Figure 13

\section{PRTR/309 Building}

The PRTR/309 Building schedule is depicted in Figure 14

\section{FFTF}

The FFTF FY 1999 and 2000 standby schedule is depicted in Figure 15 The reparr/upgrade of fuel handing equipment is shown to its completion

\section{RL Milestones}

Figure 16 identıfies all of the active RL milestones being pursued in FY 2000 TPA milestones which are the subject of pending change requests are identified in Section 30 but are not included in the FY 2000 baseline because of the FFTF being placed in Standby

\section{Cost Summary}

Lifecycle costs for NE Legacies and PRTR/309 Building are identified in Table 11 This table also includes FY 1997 and FY 1998 EM funded costs for the FFTF These are included for completeness of the Advanced Reactors Transition Project Baseline Summary (PBS RL-TP11) lifecycle costs

FFTF standby costs are planned for FY 2000 only and total $\$ 41812 \mathrm{~K}$ In addition laundry charges of \$98K are paid directly by RL hoidback of appropnated project funds These values are also presented in Table 12 A more detailed breakdown of the FFTF costs is provided in section 4 Costs beyond FY 2000 will be determined based on mission direction 


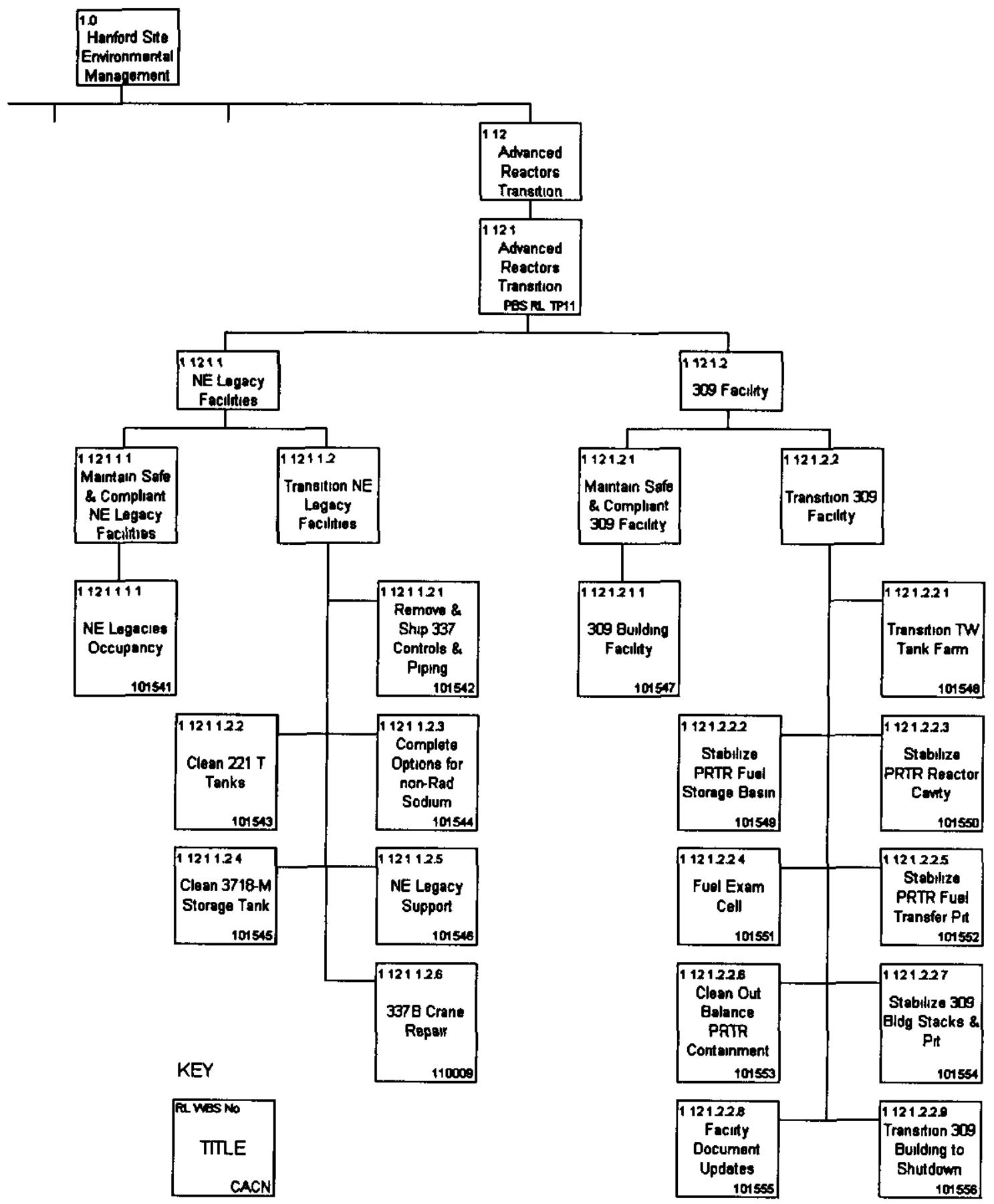

Figure 11 Advanced Reactors Transition (RL-TP11) Work Breakdown Structure 


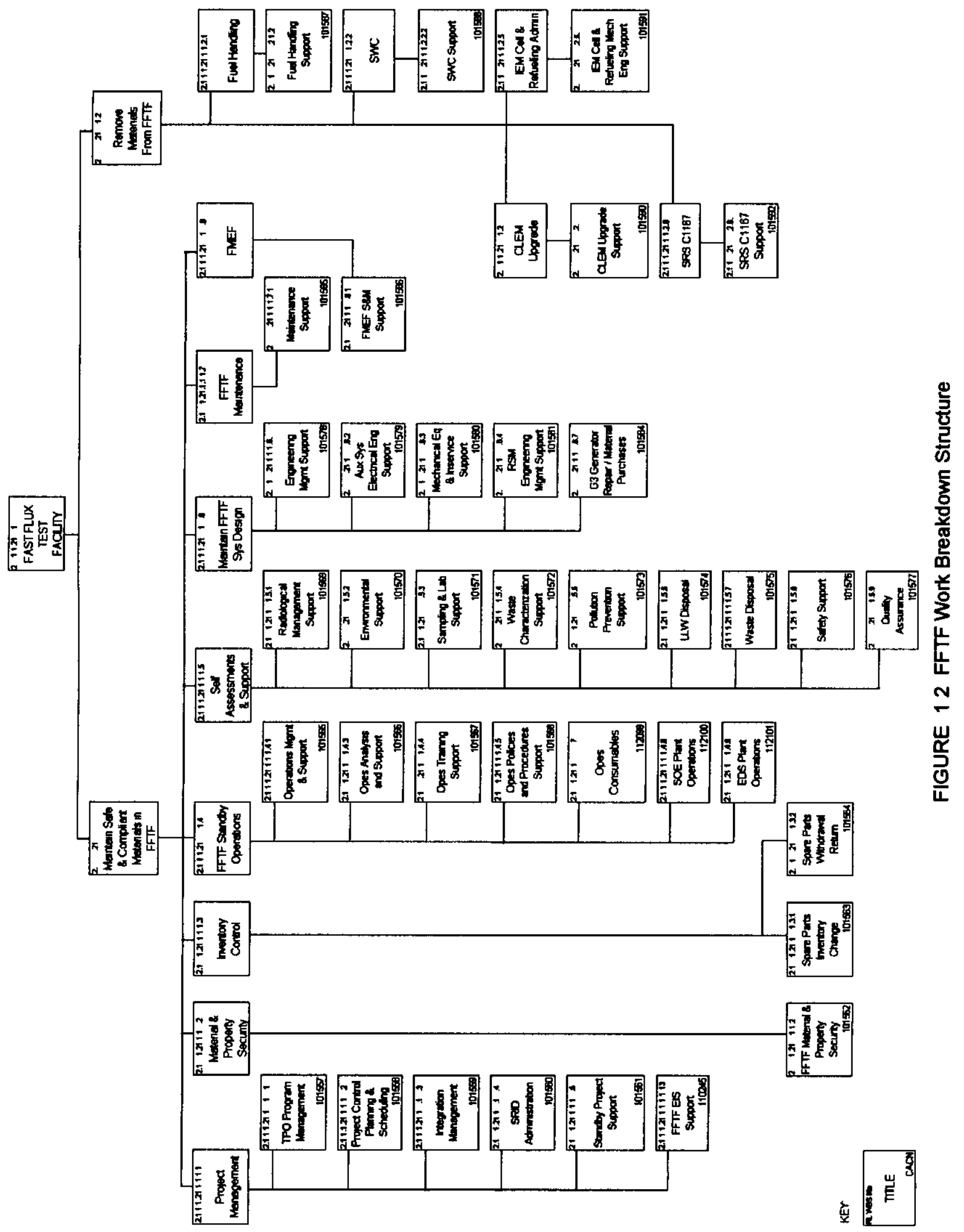




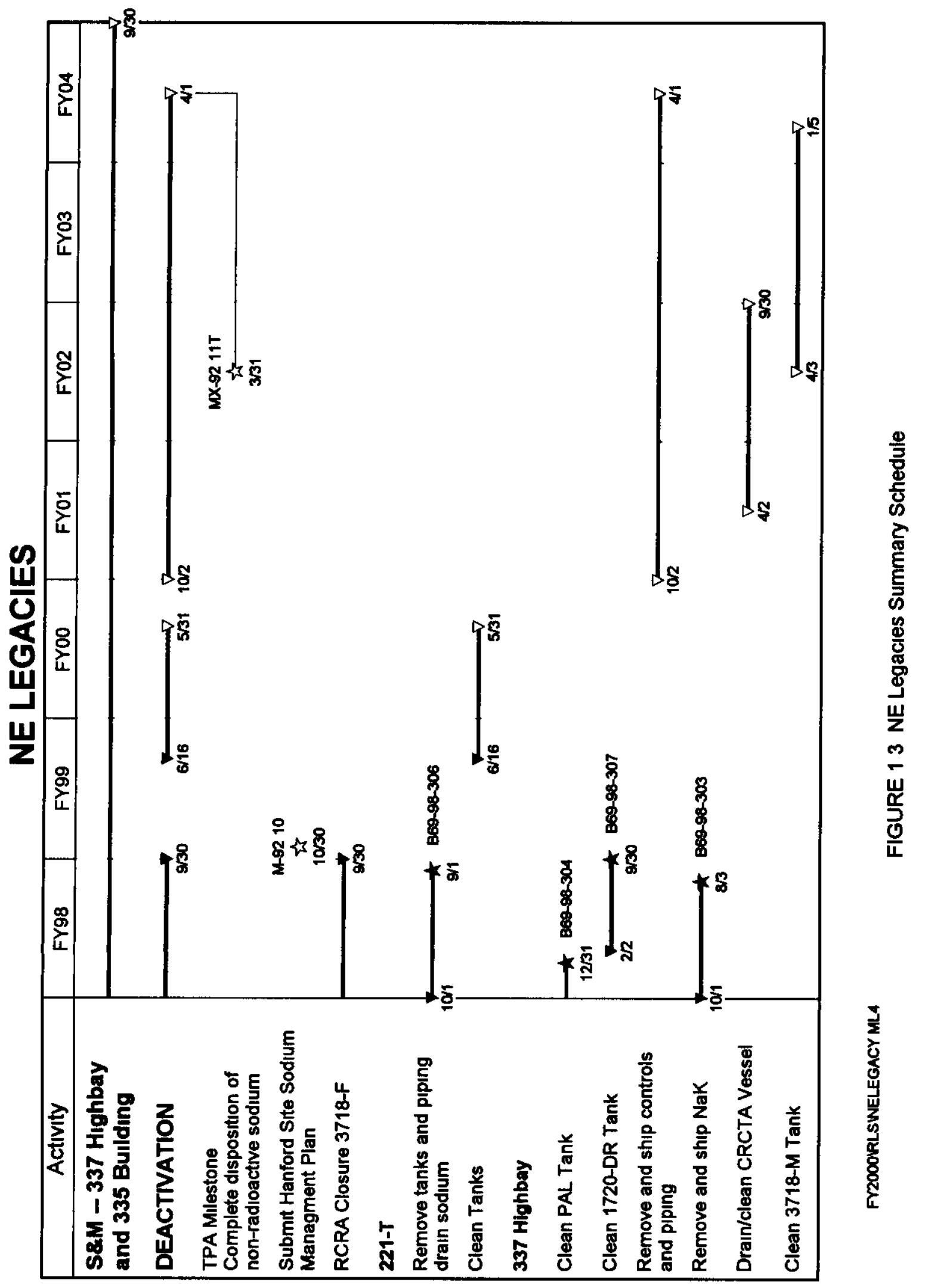


HNF SD-FF-SSP-050

Rev 8 Page 6

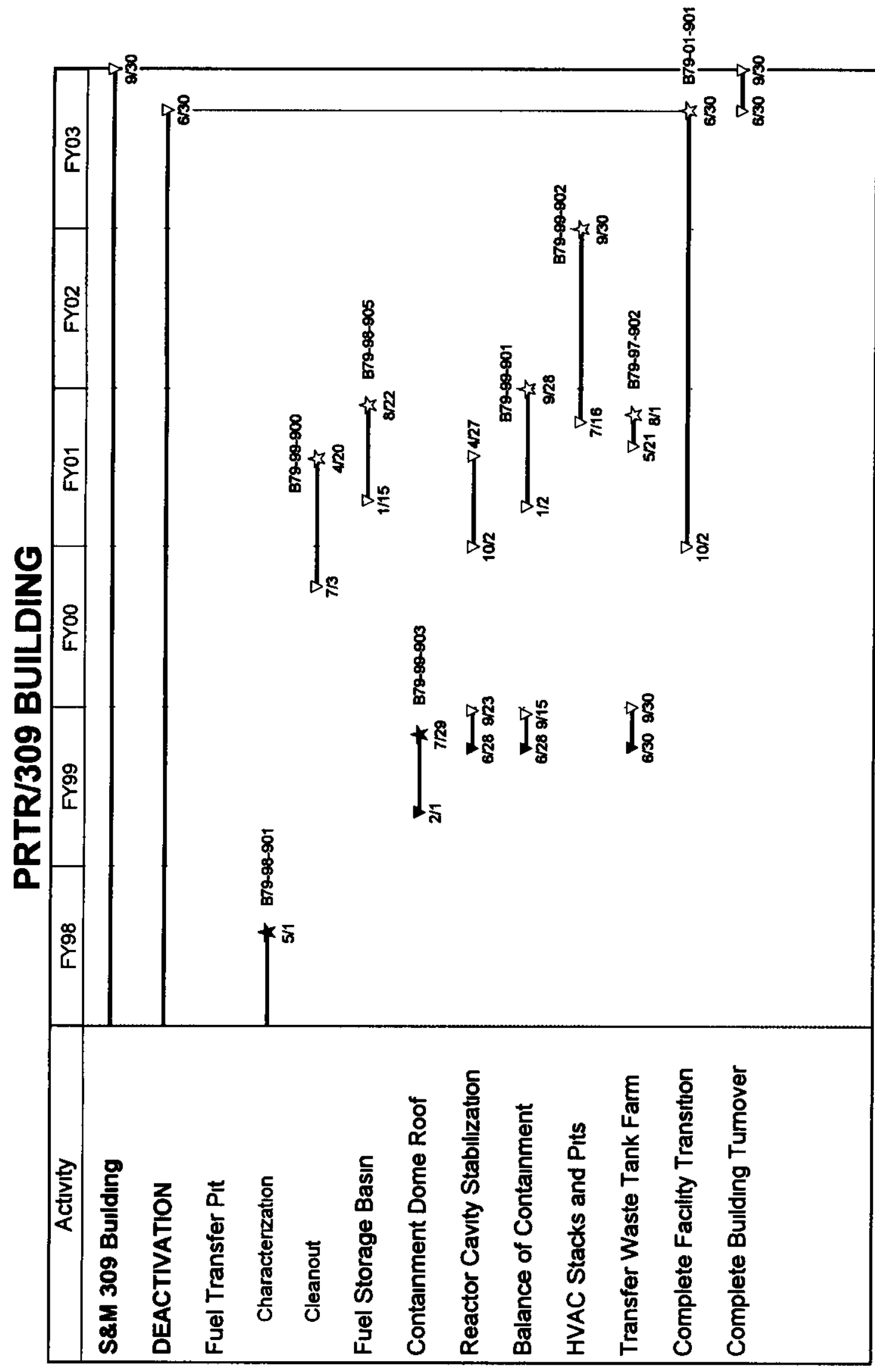

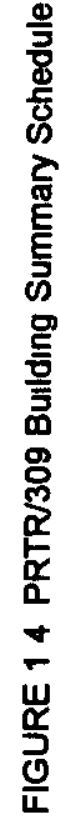


HNF SD-FF SSP-050

Rev 8 Page 7

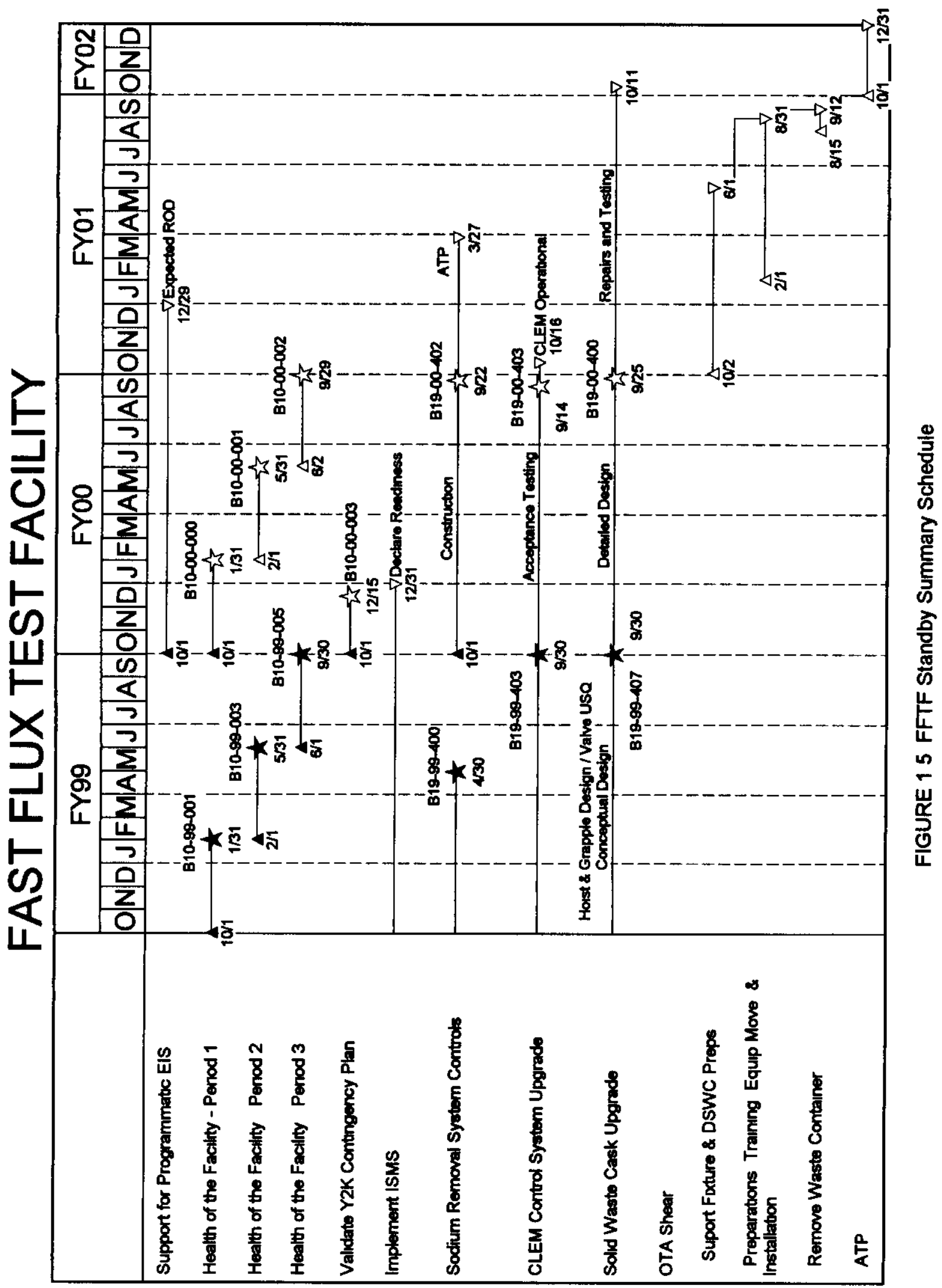


HNF-SD-FF-SSP 050

Rev 8 Page 8

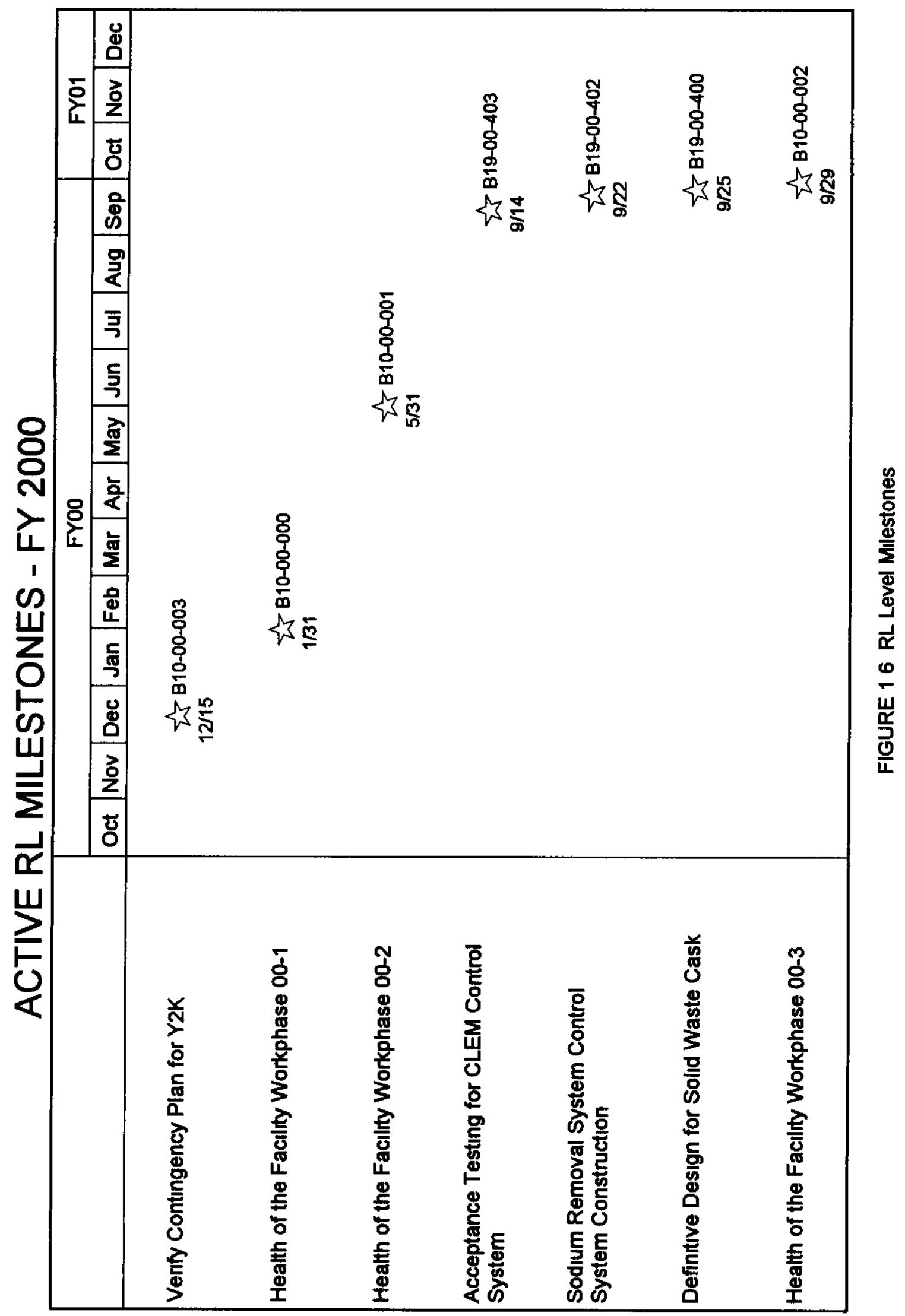




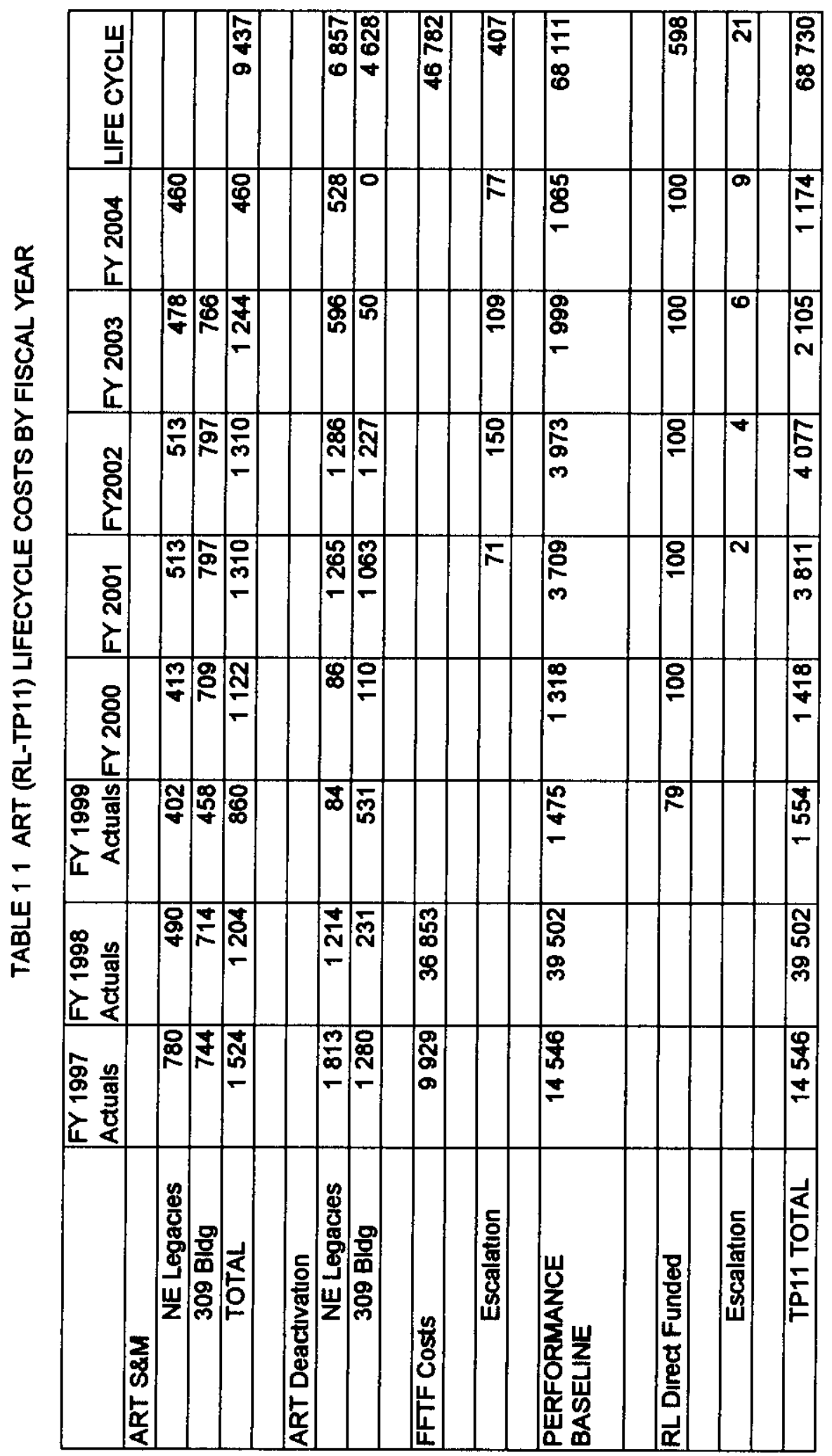


HNF SD-FF-SSP-050

Rev 8 Page 10

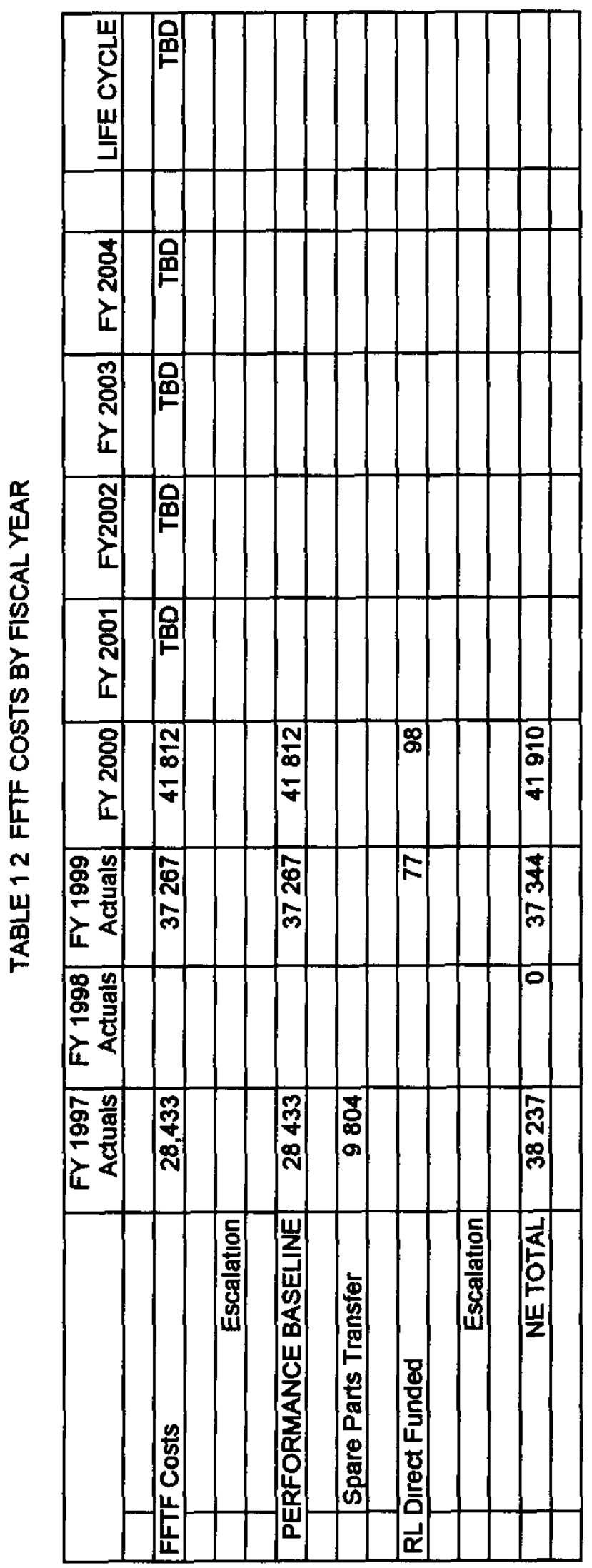




\title{
21 Mission
}

The Advanced Reactors Transition (ART) Program has two missions One funded by DOE EM is to transition assigned, surplus facilities to a safe and compliant, low cost stable deactivated condition (requiring minimal survellance and maintenance) pending eventual reuse or D\&D Facilities to be transitioned include the 309 Buldıng / Plutonıum Recycle Test Reactor (PRTR) and Nuclear Energy Legacy facilities This mission is funded through the Environmental Management (EM) Project Baselıne Summary (PBS) RL-TP11 Advanced Reactors Transition

The second mission funded through the Office of Nuclear Energy Science and Technology (DOE NE) is maintainıng the Fast Flux Test Faclity (FFTF) the Fuels and Matenals Examınatıon Facility (FMEF) and affiliated $\mathbf{4 0 0}$ Area buildings in a safe and compliant standby condition This mission is to preserve the condition of the plant hardware software and personnel in a manner not to preclude a plant restant

\section{Background}

The Secretary of Energy announced a decision on January 151997 (Reference 6) directıng that the FFTF is to be maintained in a standby condition to permit the U S Department of Energy (DOE) to make a decision on whether the facility should play a future role in the DOE dual track tntıum production strategy A decision was announced in March 1999 that the FFTF would not be included in the tntium mission options However an additional study was directed to further evaluate alternative missions to produce medical and other isotopes On August 181999 the Secretary of Energy announced that an EIS would be developed to consider the operation of the FFTF for isotope production Notice of the intent to conduct a programmatic EIS was published in the Federal Register on September 151999

Direction to implement the FFTF Standby Program was provided from the DOE RIchland Operations Office (RL) by Reference 7 and forwanded by the Project Hanford Management Contractor for action by Reference 8 The previous DOE directives (Reference 9 and Reference 10) regarding the shutdown of the FFTF are deferred by this decision

The FFTF Standby Plan (Reference 1) defines the implementatıon of the DOE standby directives by the FFTF The pnor FFTF Stabilization Project Plan (Reference 11) has been placed on hold and was superseded by the issuance of the Standby Plan

\section{Scope}

This revision of the RLS is based upon the technical scope in the latest revision of the following project and management plans

\author{
Fast Flux Test Facilty Standby Plan (Reference 1) \\ Hanford Site Sodıum Management Plan (Reference 2) \\ 309 Buıldıng Transition Plan (Reference 4)
}

The technical scope cost and schedule baseline is also in agreement with the concurrent revision to the ART FIscal Year (FY 2000 Multt-Year Work Plan (MWWP)

\section{NE Legacies}

The Nuclear Energy Legacy subproject will disposition the alkalı metal test loops which were utilized in the development of liquid metal reactor systems technology This subproject has been in progress since 1995 when Environmental Assessment Disposition of Alkalı Metal Test Loops Hanford Site Richland Washington DOE/EA-0987 was Issued 
Remaining scope to be accomplished is

- Drain and clean the Composite Reactor Component Test Activity (CRCTA) which contains an estımated 2800 gallons of sodium

- Clean the two previously drained sodium tanks from 221-T

- Clean the previously draıned $3718-\mathrm{M}$ sodium storage tank

- Clean the NaK residuals from the cold trap cooling system

- Disposition sodium wetted piping and components such as valves from 337B based on the FFTF mission decision

- Remove and disposition the 337B Highbay cold trap

NE Legacy objectives in FY 2000 are

- Provide survellance and maıntenance of the 337B Hıghbay $3718 \mathrm{M}$ storage tank building and 335 Bullding

- Clean the two previously draıned sodium tanks from $221 \mathrm{~T}$

\section{Buildıng/PRTR}

The 309 Buildıng/PRTR subproject will stabilize the facilty and configure it to require minımum survellance and maintenance pending final decommissioning and demoition This will involve sampling and charactenzation of the facility removal and disposal of hazardous matenals and stabilization of residual contaminants Specific activities remaining to be completed include

- Stabilize the Transfer Waste Tanks and associated equipment

- Stabilize the fuel storage basin

- Stabilize the PRTR reactor cavity

- Stabilize the fuel transfer pit

- Clean out the balance of the containment

- Stabilize the HVAC stack and fitter pit

- Upgrade the roof on the office/shop sections of the building to a sound condition

- Complete turnover documentation and files

309 Buildıng/PRTR objectives for FY 2000 are

- Perform surveillance and maintenance of the 309 Buildıng

- Initrate cleanout and stabilization of the fuel transfer pit

\section{FFTF}

The FFTF being in a standby condition has only the current year scope defined The life cycle scope will be determined based on the DOE record of decision expected in December 2000

Near term FFTF objectives include

- Maıntain the health of the facility by performıng scheduled preventive maintenance and priontized corrective maintenance

- Restore on-site back up AC power generation capability

- Complete the design for the Solıd Waste Cask (SWC) repair Restore the SWC to operable status in FY 2001

- Complete CLEM control system upgrade acceptance testıng field work

- Complete the installation of upgrades to the Sodium Removal System controls control panel C 1167

- Support the DOE Programmatic Environmental Impact Statement (PEIS) process by providing requested planning information

\section{Assumptions}

- The FFTF will remain in standby throughout FY 2000 Should the DOE issue a mission decision necessary changes will be implemented by BCR

- Tr-Party Agreement (TPA) milestones related to the FFTF have been placed in abeyance per approved TPA Change Request M-81-98-01 This change was approved August 241999 and will be implemented by the project by BCR 
- The Hanford Site sodium related TPA milestones will be placed in abeyance also, per pending TPA change request

\section{Work Breakdown Structure}

The separate budgeting processes for the two missions result in two separate and independent work breakdown structures The NE Legacies and the 309 Building/PRTR being EM activities are a part of the Hanford Site Environmental Management work breakdown structure 10 The FFTF scope being budgeted from DOE-NE is classified as "work for others" and is therefore grouped as a part of the 20 work breakdown structure

Figure 21 shows the EM work scope under PBS RL-TP11

Figure 22 shows the FFTF Work Breakdown Structure startıng at the FFTF level 2010101210101 The levels above FFTF are

\begin{tabular}{|l|l|}
\hline 2 & Work for Others \\
\hline 201 & Headquarters (HQ) \\
\hline 20101 & PHMC \\
\hline 2010101 & BWHC \\
\hline 201010121 & Non-EM \\
\hline 20101012101 & FFTF Project \\
\hline
\end{tabular}

241 Work Breakdown Structure Dictionary Each level of the work breakdown structures owned by ART is defined in the pages following the Work Breakdown Structure figures

242 Responsibility Assignment Matrux

Table 2-1 designates the manager responsible for each element of the work breakdown structure 


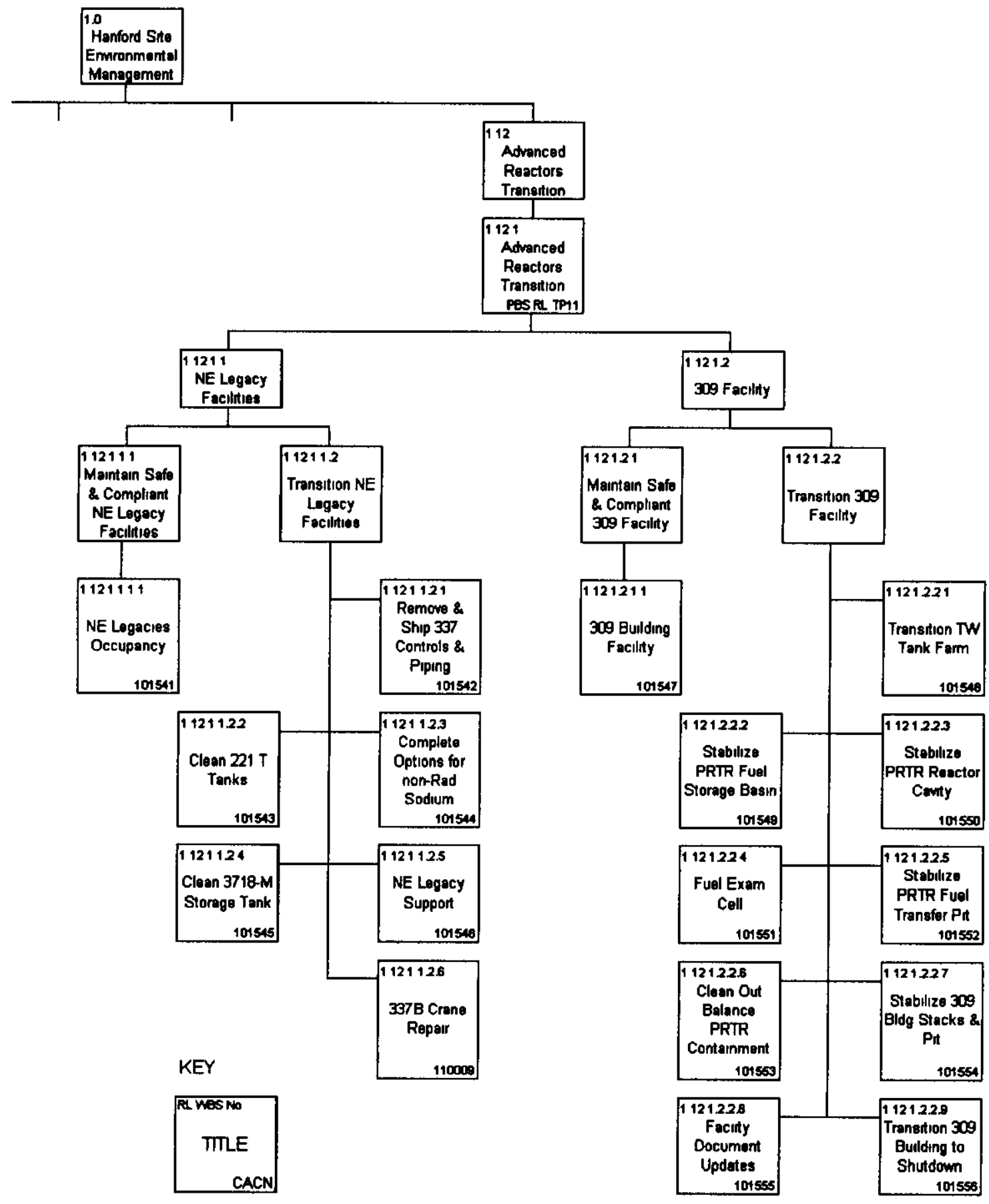

Figure 21 Advanced Reactors Transition (RL-TP11) Work Breakdown Structure 


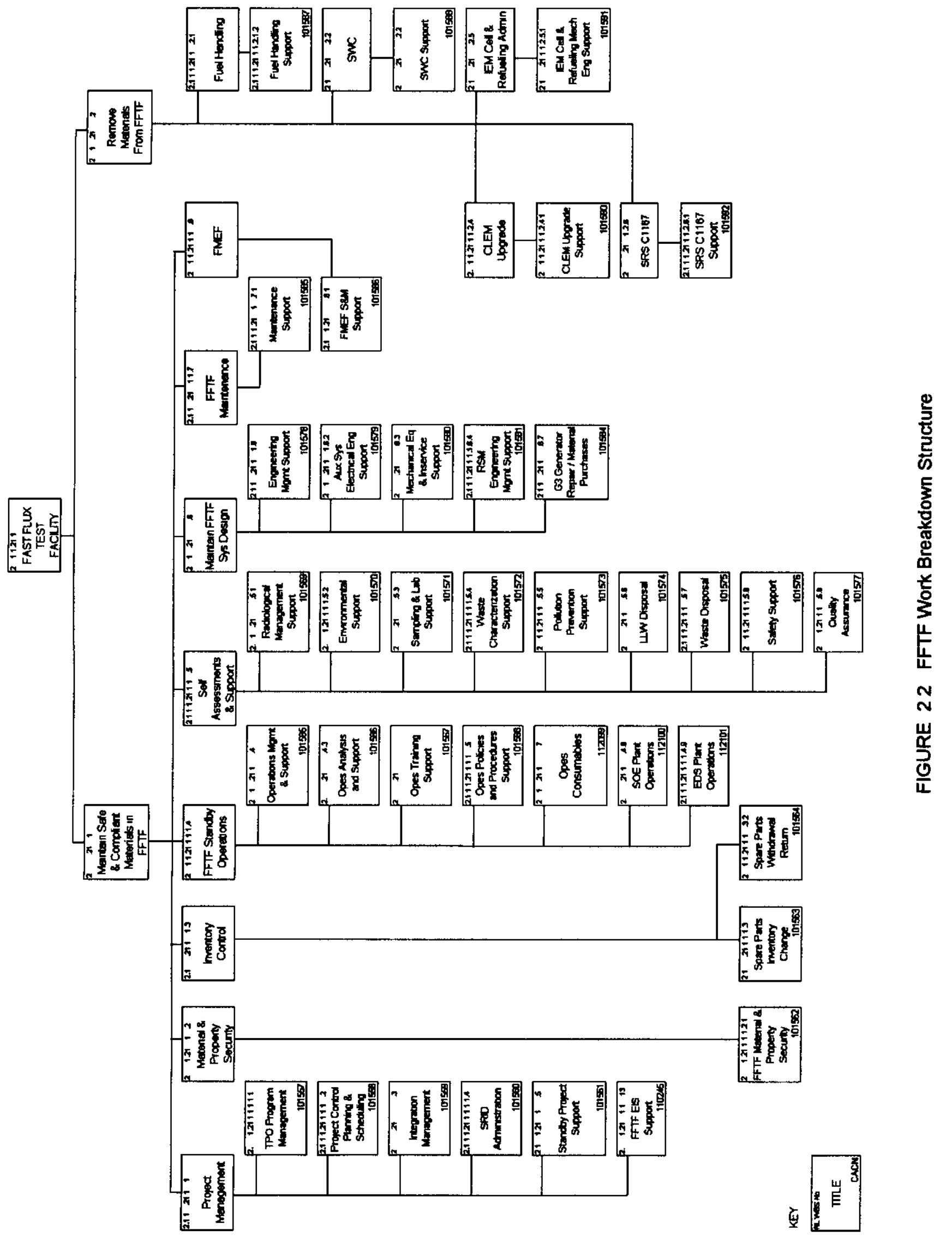




\section{Hanford Site Work Breakdown Structure Dictionary Advanced Reactors Transition WBS 112}

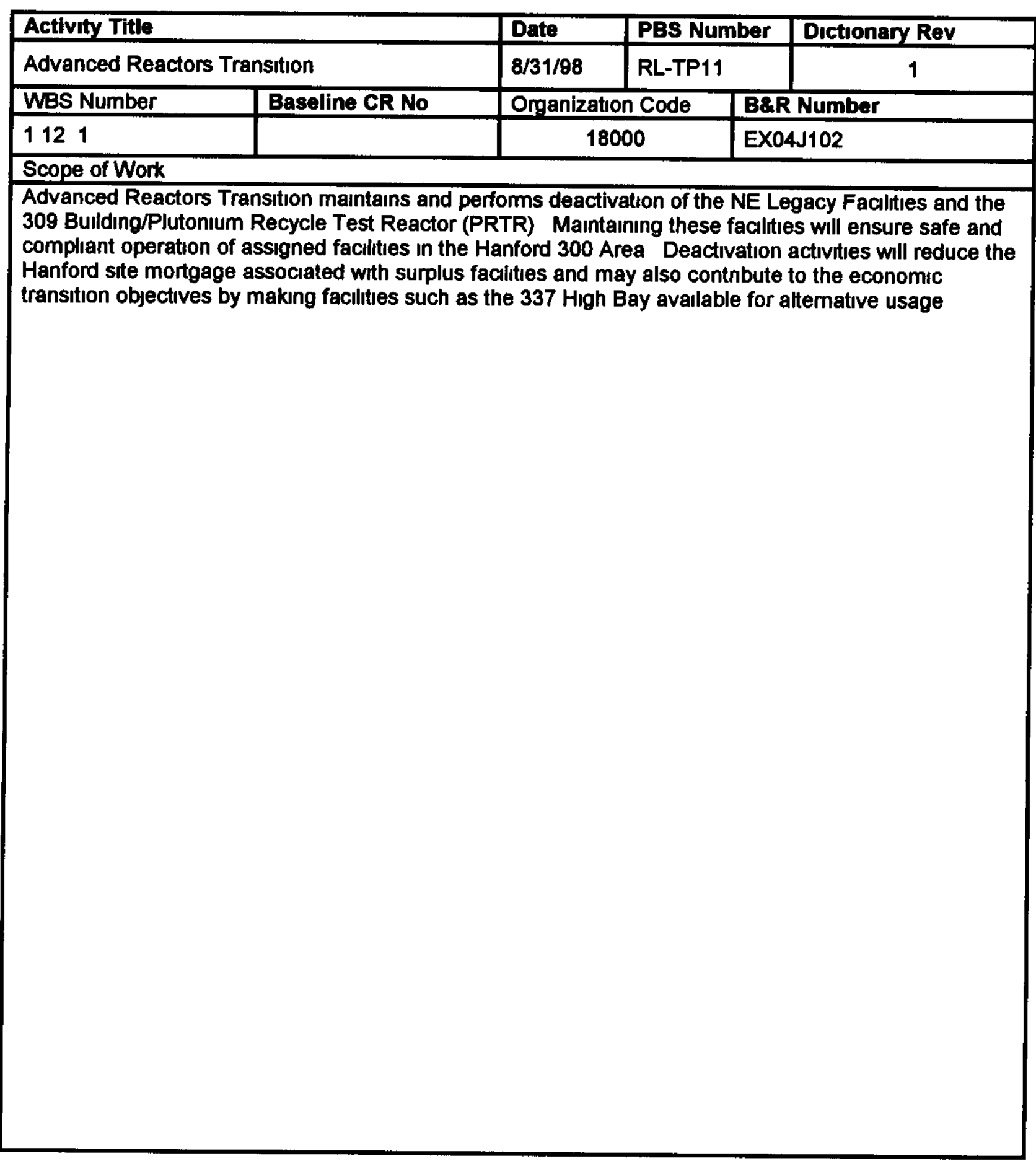




\section{Hanford Site Work Breakdown Structure Dictionary Advanced Reactors Transition WBS 112}

\begin{tabular}{|l|l|l|l|l|}
\hline \multicolumn{2}{|l|}{ Activity Title } & Date & PBS Number & Dictıonary Rev \\
\hline NE Legacy Facilitıes & $8 / 31 / 98$ & RL-TP11 & 0 \\
\hline WBS Number & Baseline CR No & Organızatıon Code & B\&R Number \\
\hline 11211 & & \multicolumn{2}{|c|}{18200} & EX04J102 \\
\hline
\end{tabular}

Scope of Work

Maintain and perform deactivation of the NE Legacy Facilities These faciities used in the development of sodium system technology for design and operation of the Fast Flux Test Facklity include the 335 Builing the $3718 \mathrm{M}$ Building and the 337 High Bay all located in the southeast section of the 300 Area

Sodium test systems in the 335 Building have been dismantled and the facility is being used for storage and staging of matenals and equipment associated with the NE Legacy Facilities The 3718M

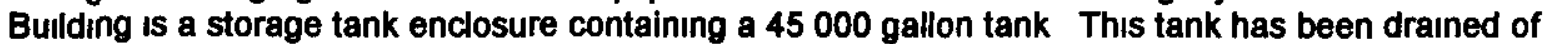
the bulk sodium and is held under inert gas blanket pending final cleaning of sodium residuals The 337 High Bay contains a developmental sodium test loop and partial FFTF reactor vessel mock up contaınıng an estımated $\mathbf{2} \mathbf{8 0 0}$ gallons of metallic sodium 


\section{Hanford Site Work Breakdown Structure Dictionary Advanced Reactors Transition \\ WBS 112}

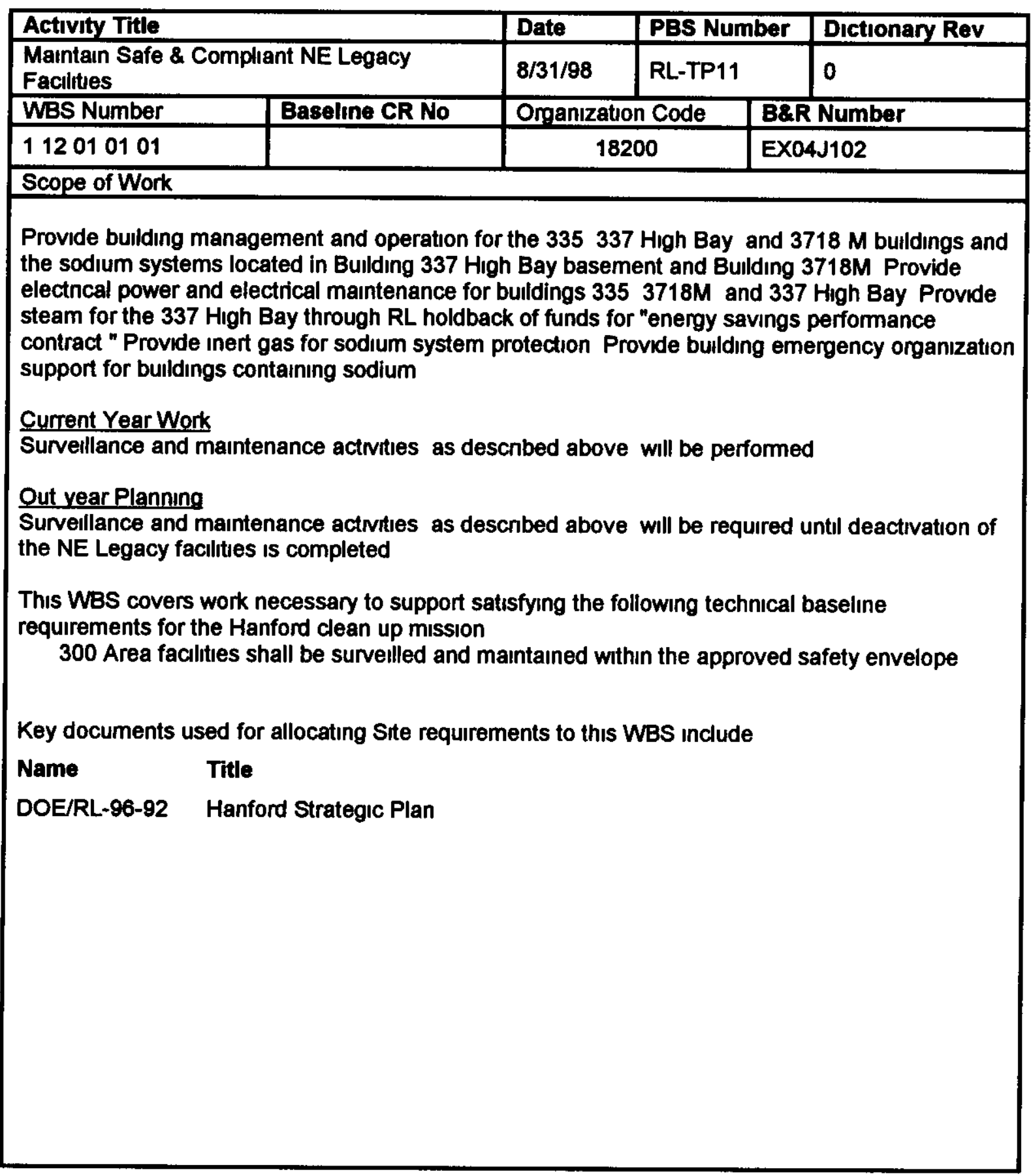




\section{Control Account Dictionary Advanced Reactors Transition WBS 112}

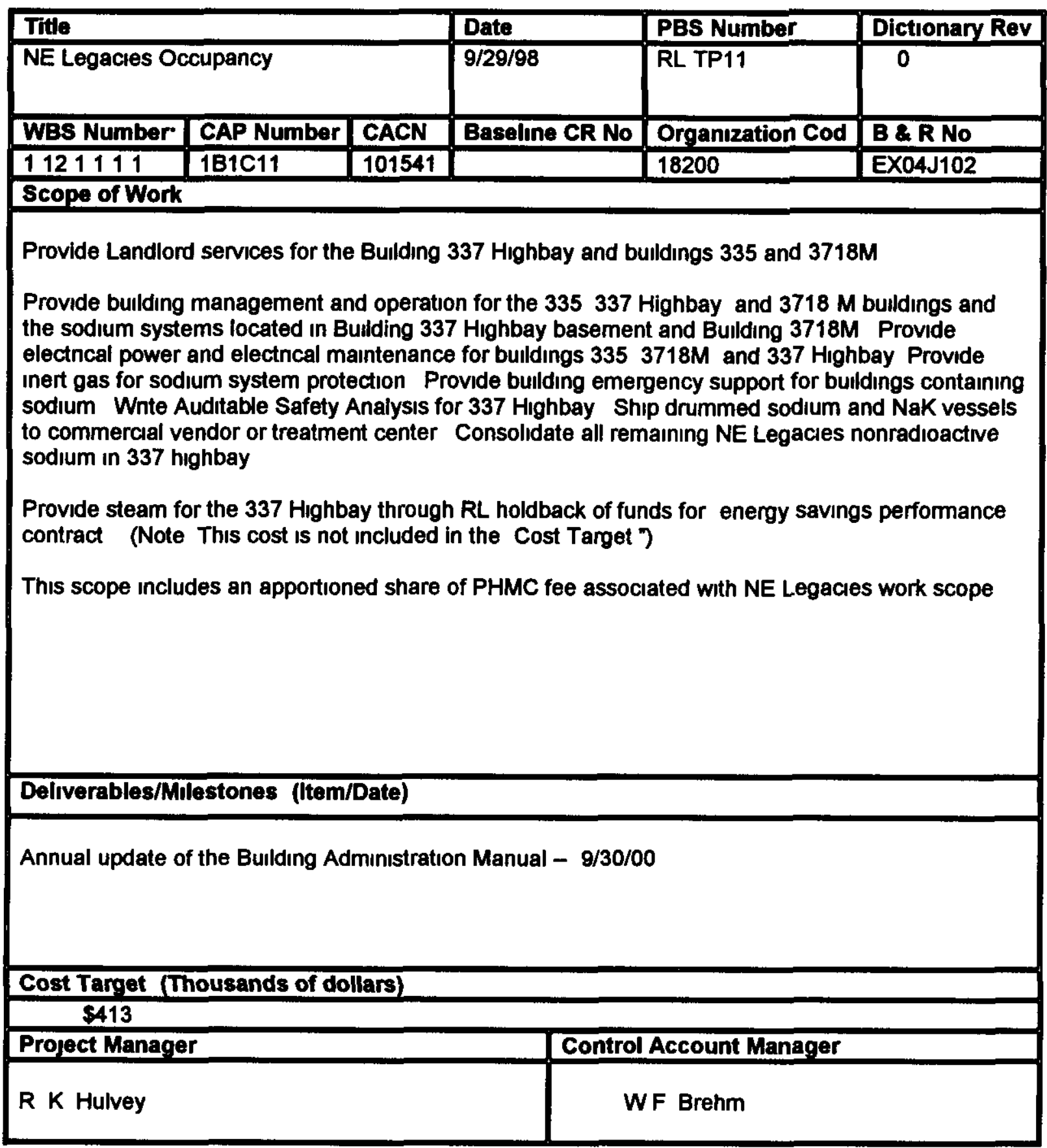




\section{Hanford Site Work Breakdown Structure Dictionary Advanced Reactors Transition} WBS 112

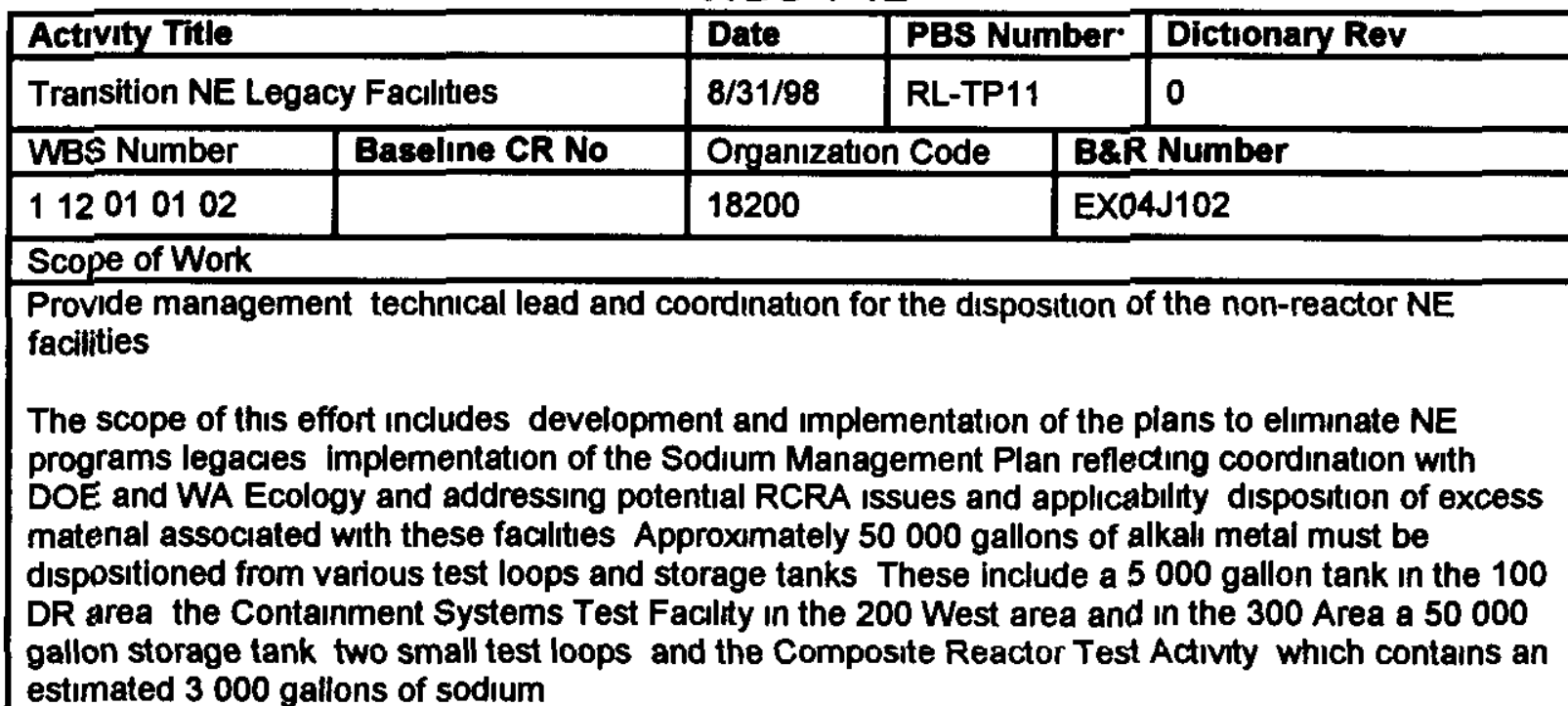
estımated 3000 gallons of sodium

\section{Current Year Work}

Only about 3000 gallons of this sodium remains to be dispositioned and all of it is in the 337-B high bay or the 3718-M drain tank Dunng FY 2000 the residual sodium will be cleaned from the $221 \mathrm{~T}$ storage tanks and the sodium wetting station The systems will be established in a safe laid-up condition pending pnonty to complete cleanout of the Composite Reactor Component Test Activity and the associated pipıng and the 3718-M drain tank residuals

Out vear Planning

The High Temperature Sodium Facility including the Composite Reactor Component Test Activity (CRCTA) its cold trap and interconnecting piping must be dispositioned The piping will be removed cut up packaged and shipped off site for disposal The CRCTA vessel will be drained if necessary before it and the 3718-M storage tank are cleaned in place to remove sodium residuals The cold trap will be removed and dispositioned This work is estımated to require about 3-1/2 years to complete

This WBS covers work necessary to support satısfying the following technical baselıne requirements for the Hanford clean up mission

- Disposal of Alkalı Metal Test Loops will comply with DOE/EA-0987

High cost surplus facikities and systems shall be transitioned to a low cost stable deactivated condition

Facilities and systems shall be made avallable for other uses

Complete acquisition of new facilities modification of existing facities and/or modification of planned facilities necessary for the storage treatment/processing and disposal of Hanford Site Sodıum (Na) [Due Date TBD]

- TPA Milestone M 92-10 Submit Hanford Site sodium project management plan (PMP) to Ecology pursuant to agreement action plan section 115 [Due Date October 1998]

Complete disposition options for all Hanford non radioactive sodium [Due Date 3/31/2002] Key documents used for allocating Site requirements to this WBS include Name Title

DOE/EA-0987

DOE/EIS-0222D

Comprehensive

DOE/RL-89-10 Hanford Federal Facility Agreement and Consent Order (Tn Party Agreement) Revision 5 Hanford Strategic Plan 


\section{Control Account Dictionary \\ Advanced Reactors Transition WBS 112}

\begin{tabular}{|c|c|c|}
\hline Titile & PBS Number & Dictionary Rov \\
\hline Clean 221-T Tanks & RL-TP11 & 0 \\
\hline CAP Number CACN & 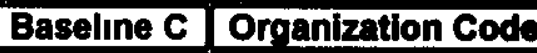 & EER No \\
\hline \begin{tabular}{|l|l|}
$1 \mathrm{~B} 1 \mathrm{C} 22$ & 101543 \\
\end{tabular} & 18200 & EX04 102 \\
\hline \multicolumn{3}{|l|}{ Scope of Work } \\
\hline \multicolumn{3}{|c|}{$\begin{array}{l}\text { This scope relates to two sodium storage tanks previously removed from 221-T } \\
\text { Bulding during deactivation of the Containment Systems Test Facility The bulk } \\
\text { sodium has been drained from these tanks and shipped off site }\end{array}$} \\
\hline \multicolumn{3}{|c|}{$\begin{array}{l}\text { Clean the sodium residuals from the two tanks using the moist nitrogen vapor } \\
\text { process Concentrated caustic will be removed and used as product The final rinse } \\
\text { water will be sampled and verified acceptable for disposal through the } 300 \text { Area } \\
\text { process sewer }\end{array}$} \\
\hline \multicolumn{3}{|c|}{ The two tanks will be empty, clean, and in condition for excess or reuse } \\
\hline \multicolumn{3}{|l|}{ Deliverables/Milestones (item/Date) } \\
\hline \multicolumn{3}{|c|}{ The two tanks will be empty, clean, and in condition for excess or reuse } \\
\hline \multicolumn{3}{|l|}{ Cost Tarpet (Thousands of dollars) } \\
\hline \multicolumn{3}{|l|}{$\$ 86$} \\
\hline Project Manager & Control Account Manager & \\
\hline $\mathrm{R} \mathrm{K}$ Hulvey & WF Brehm & \\
\hline
\end{tabular}




\section{Hanford Site Work Breakdown Structure Dictionary Advanced Reactors Transition WBS 112}

\begin{tabular}{|c|c|c|c|c|}
\hline \multicolumn{2}{|l|}{ Activity Thle } & Date & PB8 Number: & Dictionary Rov \\
\hline \multicolumn{2}{|l|}{309 Facility } & $8 / 31 / 98$ & RL-TP11 & 0 \\
\hline WBS Number & Baseline CR No & \multicolumn{2}{|c|}{ Organization Code } & BRR Number \\
\hline 11212 & & \multicolumn{2}{|c|}{19100} & EX04J102 \\
\hline \multicolumn{5}{|l|}{ Scope of Work } \\
\hline \multicolumn{5}{|c|}{$\begin{array}{l}\text { The PRTR/309 Building work scope includes the surveillance and operation of the facility subject to } \\
\text { DOE Onders and federal codes for radiological facilities The deactivation and compliance activities } \\
\text { prepare the building for acceptance by EM-40 for long-term survellance and maintenance pending } \\
\text { decontamination and decommissioning Activities will dispose of equipment, components and } \\
\text { waste products associated with the PRTR reactor systems including all nonessential systems (e g } \\
\text { heating ventilating and air conditioning (HVAC) electrical distribution monitoring and fiuid) which } \\
\text { will be shutdown and drained or de-energized The process laboratory, and office areas of the } \\
\text { facilly will be secured to convert the facility to a minimum safe S\&M condition for turnover to an } \\
\text { ERC for long-term interim surveillance preparatory to a final D\&D phase }\end{array}$} \\
\hline
\end{tabular}




\section{Hanford Site Work Breakdown Structure Dictionary Advanced Reactors Transition WBS 112}

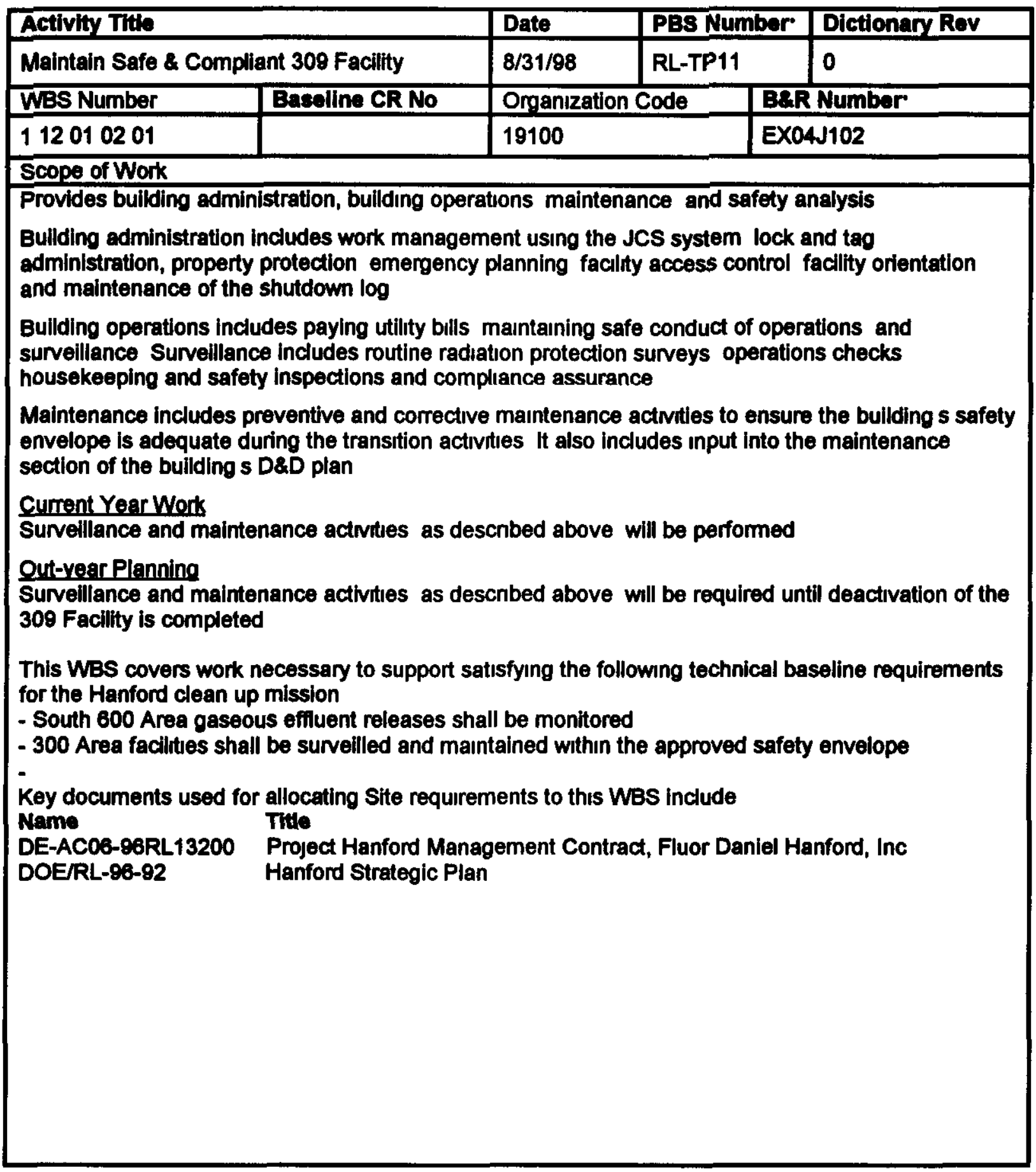




\section{Control Account Dictionary \\ Advanced Reactors Transition \\ WBS 112}

\begin{tabular}{|c|c|c|}
\hline Titie & Date & Dictionary Re \\
\hline 309 BUILDING FACILITY & 9/29/98 & RL-TP11 \\
\hline CAP Number CACN & Baseline CR No & Organization Code: B \& R No \\
\hline \begin{tabular}{|l|l} 
1B1D01 & 101547 \\
\end{tabular} & & \begin{tabular}{l|l}
19100 & EX04J102 \\
\end{tabular} \\
\hline \multicolumn{3}{|l|}{ Scope of Work } \\
\hline \multicolumn{3}{|c|}{$\begin{array}{l}\text { S\&M activities include building administration building operations maintenance and safety analysis } \\
\text { Building administration consists of work management using the Job Control System (JCS) lock and } \\
\text { tag administration property protection emergency planning facility access control personnel training } \\
\text { and facility orientation } \\
\text { Building operations consists of utility assessments, management assessments, procedure } \\
\text { maintenance maintaining safe conduct of operations, and surveillance Surveillance includes routine } \\
\text { radiation protection surveys operations checks, housekeeping and safety inspections exhaust stack } \\
\text { periodic confirmatory sampling and compliance assurance } \\
\text { Maintenance includes preventive and corrective maintenance actwities to ensure the building's safety } \\
\text { envelope is adequate during the transition activities It also includes input into the maintenance } \\
\text { section of the building's D\&D plan } \\
\text { This scope includes an apportioned share of PHMC fee associated with PRTR work scope }\end{array}$} \\
\hline \multicolumn{3}{|l|}{ Deliverables/Milestones (item/Date) } \\
\hline \multicolumn{3}{|l|}{ No discrete deliverables } \\
\hline \multicolumn{3}{|l|}{ Cost Tarret (Thousands of dollars) } \\
\hline \multicolumn{3}{|l|}{$\$ 709$} \\
\hline Project Manager & Control Acc & Ount Manager \\
\hline R K Hulvey & I L Metcalf & \\
\hline
\end{tabular}




\section{Hanford Site Work Breakdown Structure Dictionary Advanced Reactors Transition WBS 112}

\begin{tabular}{|c|c|c|c|c|}
\hline \multicolumn{2}{|l|}{ Activity Title } & Date & PBS Number & Dictionary Rev \\
\hline \multicolumn{2}{|l|}{ Transition 309 Facility } & $8 / 31 / 98$ & RL-TP11 & 0 \\
\hline WBS Number & Baseline CR No & \multicolumn{2}{|c|}{ Organization Code } & BRR Number \\
\hline 112122 & & \multicolumn{2}{|l|}{19100} & EX04J102 \\
\hline \multicolumn{5}{|l|}{ Scope of Work } \\
\hline \multicolumn{5}{|c|}{$\begin{array}{l}\text { Deactivation activities to be accomplished inciude disposition of the underground emergency diesel } \\
\text { fuel oil tank, characterize, cleanout and stabilize the Transfer Waste Tank ferm, the Rupture Loop } \\
\text { Annex, the Fuel Storage Basin the Fuel Examination Cell the Fuel Transfer Basin and Fuel } \\
\text { Transfer Pht, the PRTR reactor cavity and the containment building configure surveillance lighting, } \\
\text { replace the H\&V system HEPA filters charactenze clean out and shutdown the 309-PRTR stack } \\
\text { disconnect and cap sanitary and process sewer lines remove asbestos bearing coatings from the } \\
\text { extemal surface of the dome and stabilize other friable asbestos materials and upgrade the roof on } \\
\text { other parts of the building Completion reports will be prepared for key activities }\end{array}$} \\
\hline \multirow{2}{*}{\multicolumn{5}{|c|}{$\begin{array}{l}\text { The facility Safety Basis document will be formatted in the Auditable Safety Analysis style to be } \\
\text { consistent with the graded approach philosophy of a radiological faclity rather than a nuclear facility } \\
\text { Current Year Work } \\
309 \text { Building efforts in FY } 2000 \text { will focus on clean out of the Reactor Cavity and beginning clean-out } \\
\text { of the Fuel Transfer Pit The " } 309 \text { Facilty Deactivation and Decommisioning Criteria Completion } \\
\text { Check Lists "WHC-SD-NEL-RD-001 will be maintained current with the ERC as progress continues } \\
\text { toward final deactivation and tumover }\end{array}$}} \\
\hline & & & & \\
\hline \multicolumn{5}{|c|}{$\begin{array}{l}\text { Out-year Planning } \\
\text { Clean out, characterization and stabilization will contınue on an area-by-area basis This is } \\
\text { scheduled to complete the transition checklist for tumover to the ERC in another 3-years }\end{array}$} \\
\hline \multicolumn{5}{|c|}{$\begin{array}{l}\text { This WBS covers work necessary to support satisfyıng the following technical baseline requirements } \\
\text { for the Hanford clean up mission } \\
\text { - High cost surplus facilities and systems shall be transitioned to a low cost stable deactivated } \\
\text { condition } \\
\text { - Facilities and systems shall be made available for other uses } \\
\text { - Facilities shall be transitioned to the survellance and mantenance phase when no longer required } \\
\text { to support the site mission } \\
\text { - The Contractor shall safely and efficiently manage the deactivation of the } 309 \text { Building and } \\
\text { associated facilities in the } 300 \text { Area whose mission was the space power program The program will } \\
\text { disposition nuclear material in these facilities As the material is removed, each facility will be } \\
\text { deactivated to reduce risk and attain the lowest surveillance and maintenance cost to a condition } \\
\text { ready for disposition } \\
\text { - The contractor shall clean-up the nuclear waste and stabilize the } 309 \text { Building and surrounding } \\
\text { area such that the closure of the } 309 \text { Building can be accomplished }\end{array}$} \\
\hline \multicolumn{5}{|l|}{$\begin{array}{l}\text { Key documents used for } \\
\text { Name } \\
\text { DE-AC08-96RL13200 } \\
\text { DOE/EIS-0222D } \\
\text { DOE/RL-96-92 }\end{array}$} \\
\hline
\end{tabular}




\section{Control Account Dictionary Advanced Reactors Transition WBS 112}

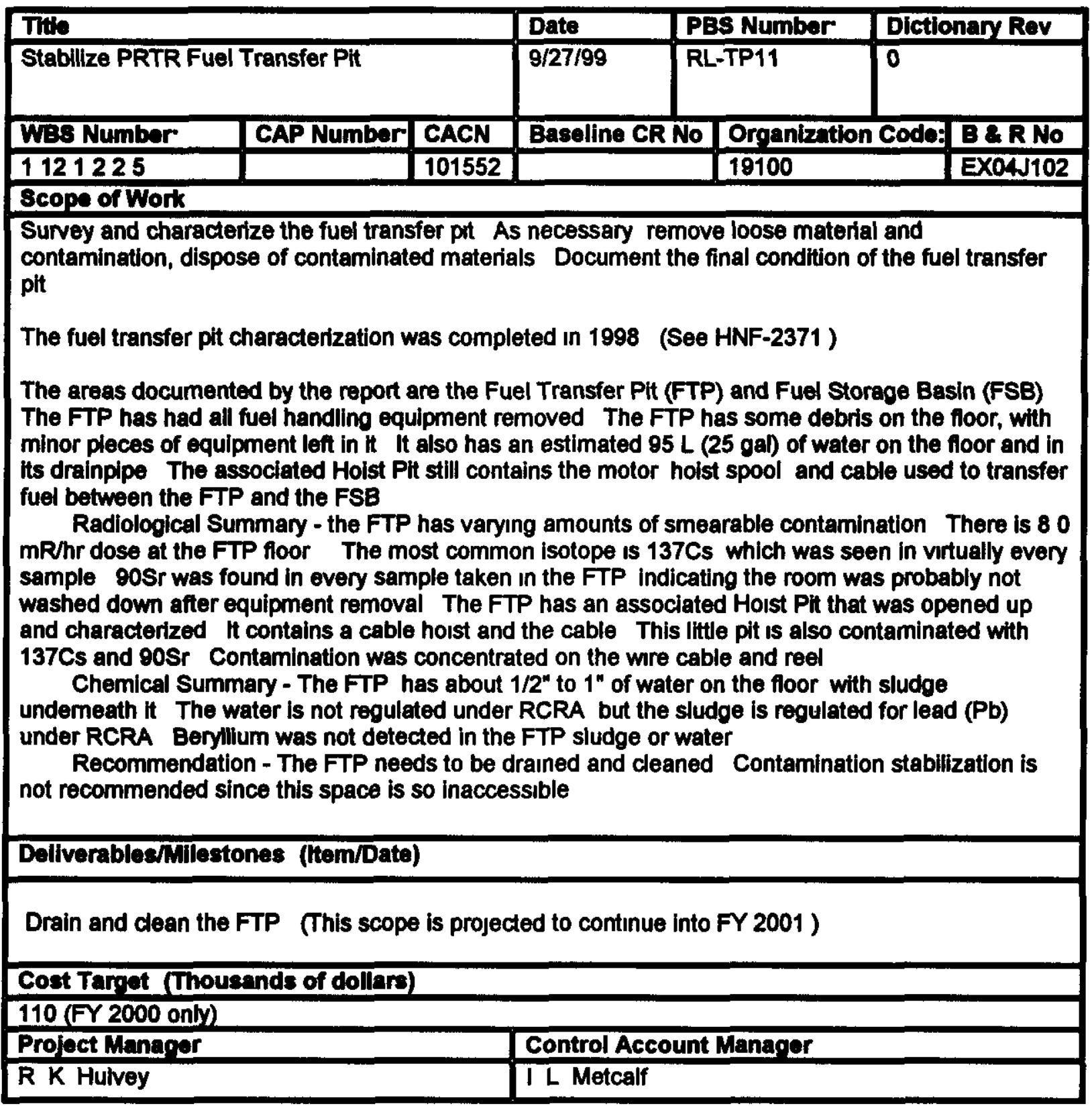




\section{Hanford Site Work Breakdown Structure Dictionary FFTF Project \\ WBS 20101012101}

\begin{tabular}{|l|l|l|l|c|}
\hline Activity Title & Date & PBS Number & Dictionary Rev \\
\hline FFTF Project & $8 / 31 / 98$ & MS01 & 0 \\
\hline WBS Number & Baselline CR No & Organization Code & BeR Number \\
\hline 20101012101 & & \multicolumn{2}{|c|}{18000} & AF79 \\
\hline Scope of Work & & \multicolumn{3}{|l}{} \\
\hline
\end{tabular}

The Fast Flux Test Facility (FFTF) Project is responsible to maintain the FFTF and support facilities in a safe and compliant condition The condition of the plant hardware software and personnel will be preserved in a manner not to preclude a plant restart

Maintain the Fast Flux Test Facility and associated facilities in a standby condition while an evaluation is conducted of any future role that the facility might have in the Department's isotope production strategies

The survellance and maintenance (S\&M) of facilities and plant systems will be performed to comply with federal and state safety requirements In the standby condition, S\&M of the FFTF shall have additional objectives to ensure that there is (a) no degradation of key plant systems, (b) retention of the authorization basis and configuration control (c) maintenance of key staffing, qualifications and training

In addition deactivation activities contunue consistent with maintaining standby such as cleaning and storing of spent fuel and other reactor components maintaining equipment required for deactivation and completing the planning necessary to resume an orderly transition to shutdown (if appropriate ) 


\section{Hanford Site Work Breakdown Structure Dictıonary FFTF Project \\ WBS 20101012101}

\begin{tabular}{|c|c|c|c|c|}
\hline \multicolumn{2}{|l|}{ Activity Title } & Date & PBS Number & Dictionary Rev \\
\hline \multicolumn{2}{|l|}{ FFTF } & $8 / 31 / 98$ & MS01 & 0 \\
\hline WBS Number & Baseline CR No & \multicolumn{2}{|c|}{ Organization Code } & BAR Number \\
\hline 2010101210101 & & \multicolumn{2}{|c|}{18000} & AF79 \\
\hline \multicolumn{5}{|l|}{ Scope of Work } \\
\hline \multicolumn{5}{|c|}{$\begin{array}{l}\text { The Fast Flux Test Facility (FFTF) located in the } 400 \text { Area includes the FFTF reactor facility the } \\
\text { Fuels and Materials Examination Facilly (FMEF) and supporting facilities Work included in this } \\
\text { scope includes maintaining safe and complaint material (control of nuclear materials) and removing } \\
\text { nuclear materials from the FFTF }\end{array}$} \\
\hline \multicolumn{5}{|c|}{$\begin{array}{l}\text { Once the FFTF has completed any future operational mission and is directed to be shutdown, } \\
\text { additional activitles, consistent with the "post-operations" phase of the lifecycle will be performed } \\
\text { These activities will include the functions of maintaining safe and compliant facilities and transitioning } \\
\text { the FFTF to a shutdown condition }\end{array}$} \\
\hline
\end{tabular}


HNF-SD-FF-SSP-050

Rev 8, Page 29

\section{Hanford Site Work Breakdown Structure Dictionary FFTF Project \\ WBS 20101012101}

\begin{tabular}{|l|l|l|l|c|}
\hline Activity Title & Date & PBS Number & Dictionary Rev \\
\hline \multicolumn{2}{|l|}{ Maintain Safe \& Compliant Materials in FFTF } & $8 / 31 / 98$ & MS01 & \multicolumn{1}{|c|}{0} \\
\hline WBS Number & Baseline CR No & Organization Code & BeR Number \\
\hline 201010121010101 & & \multicolumn{2}{|c|}{18000} & AF79 \\
\hline Scope of Work & & \multicolumn{3}{|l}{} \\
\hline
\end{tabular}

This WBS maintains the Fast Flux Test Facility and associated facilities in a standby condition while an evaluation is conducted of any future role that the facility might have in the Department's isotope production strategy

The surveillance and maintenance (S\&M) of facilties and plant systems will be performed to comply with foderal and state safety requirements Activities will include required project planning and management operation and monitoring of plant systems and components monitoring of regulated effluent streams safeguarding nuclear materials maintainıng the design of the FFTF plant systems and components, and maintaining equipment and systems operational In the standby condition, S\&M of the FFTF shall have additional objectives to ensure that there is (a) no degradation of key plant systems (b) retention of the authonzation basis and configuration control (c) mantenance of key staffing qualifications and training

Program planning activities include the preparation of budget documents program plans and schedules Performance to these plans and schedules will be montored and managed

Support will be provided to the preparer of the Environmental Impact Statement for operation of the Fast Flux Test Facility

Current Year Work

Surveillance and maintenance activities as described above, will be performed

Out-vear Planning

TBD Out-year activities will be determıned based on the assigned mission

This WBS covers work necessary to support satısfying the following technical baseline requirements for the Hanford clean up mission

- Spent fuels (light water reactor) shall be moved from the 400 Area interim storage to the Central Plateau Interim Storage

$-$

Key documents used for allocating Site requirements to this WBS include.

Name

DOE/RL-96-92 Hanford Strategic Plan 


\section{Control Account Dictionary \\ Advanced Reactors Transition \\ Fast Flux Test Facility \\ WBS 2010101210101}

\begin{tabular}{|c|c|c|}
\hline The & PEs Number & Dictionary Rov \\
\hline TPO Program Management & RL-MS01 & 0 \\
\hline CAP Number CACN & Baseline CR No Organization C & ode' B \& R No \\
\hline 21112111111 & 18300 & AF79 \\
\hline \multicolumn{3}{|l|}{ Scope of Work } \\
\hline \multicolumn{3}{|c|}{$\begin{array}{l}\text { Provide overall management direction and administrative/clerical support for the ART/FFTF program } \\
\text { management efforts This includes all financial activitles, planning and scheduling special studies, } \\
\text { reviews etc for ART/FFTF the contractor and RL Provide onsite and offsite training to meet } \\
\text { requirements for current job assignments for the TPO staff As directed provide oversight and } \\
\text { integration of the Integrated Safety Management (ISM) System Plan at FFTF support special safety } \\
\text { initiatives related to ISM } \\
\text { Administer the project s Safety First Program and Safety Improvement Plan } \\
\text { Provide the FFTF portion of the PHMC award fee pool administer the ART Performance Expectation } \\
\text { Plan } \\
\text { Provide weekly project status reports } \\
\text { Provide funding for the WMH core group responsible for corrective action management tracking }\end{array}$} \\
\hline \multicolumn{3}{|c|}{ Deliverables/Milestones (Item/Date) } \\
\hline \multicolumn{3}{|c|}{$\begin{array}{l}\text { Issue weekly project status reports } \\
\text { Conduct monthly program performance review meetings } \\
\text { Issue quartenty reports on the project s Safety First Program and Safety Improvement Plan } \\
\text { Conduct monthly reviews of TPO training status, maintain training delinquencies at zero }\end{array}$} \\
\hline \multicolumn{3}{|c|}{ Cost Tarret (Thousands of dollars) } \\
\hline \multicolumn{3}{|l|}{$\$ 3,196$} \\
\hline Program Manarer & Control Account Manager & \\
\hline $\mathbf{R}$ K Hulvey & R K Hulvey & \\
\hline
\end{tabular}




\section{Control Account Dictionary \\ Advanced Reactors Transition}

Fast Flux Test Facility

WBS 2010101210101

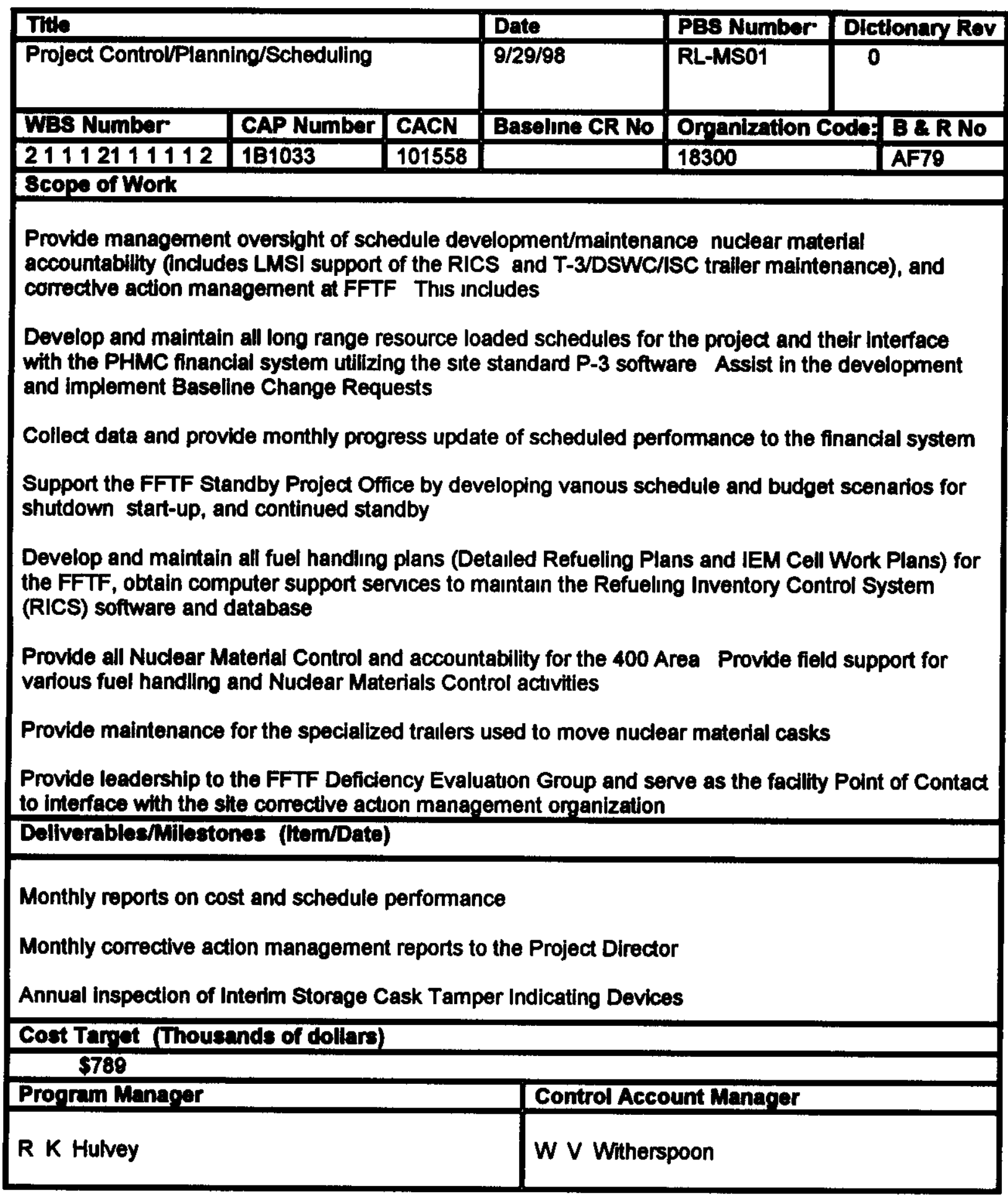




\section{Control Account Dictionary \\ Advanced Reactors Transition \\ Fast Flux Test Facility \\ WBS 2010101210101}

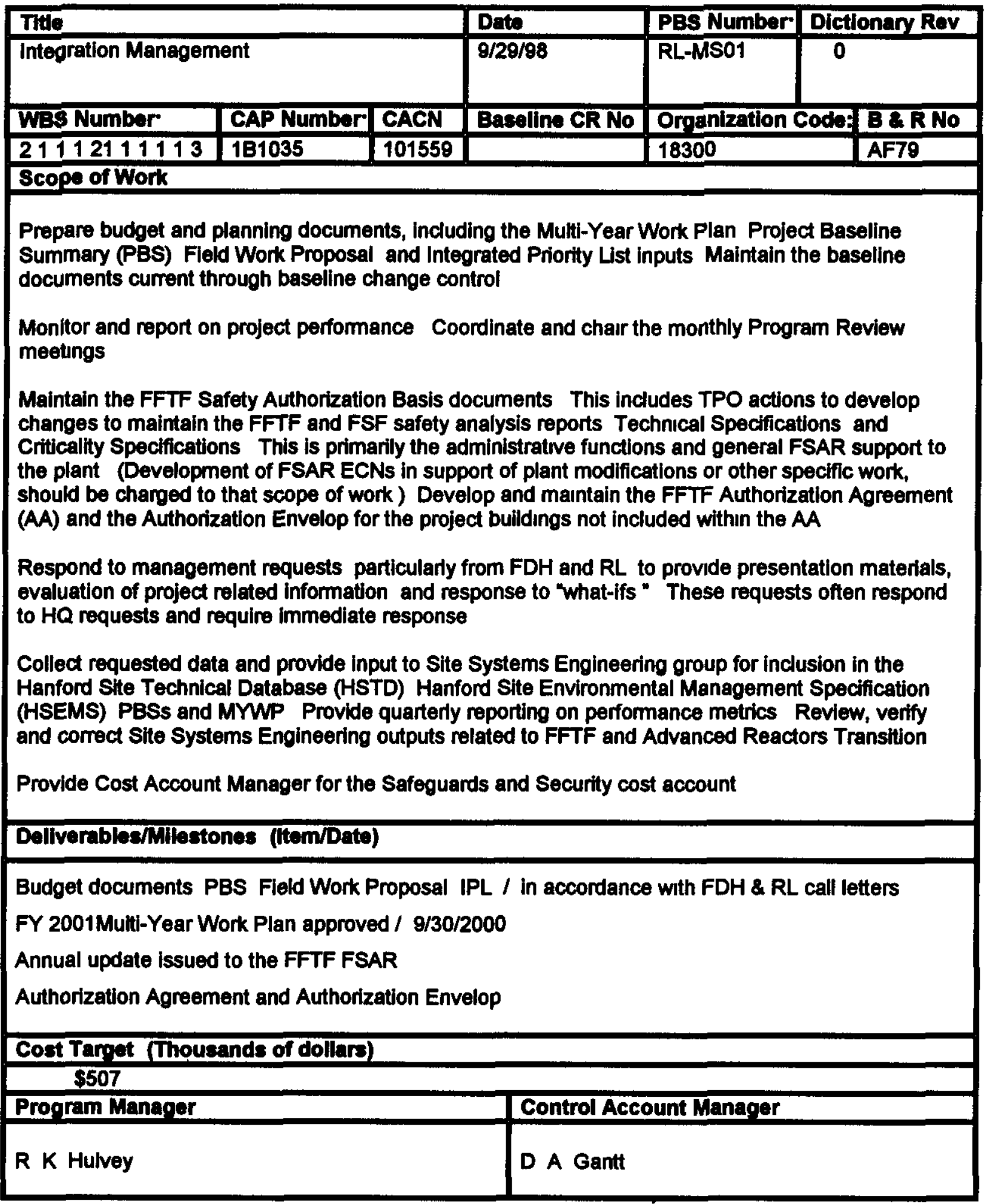




\section{Control Account Dictionary \\ Advanced Reactors Transition \\ Fast Flux Test Facility \\ WBS 2010101210101}

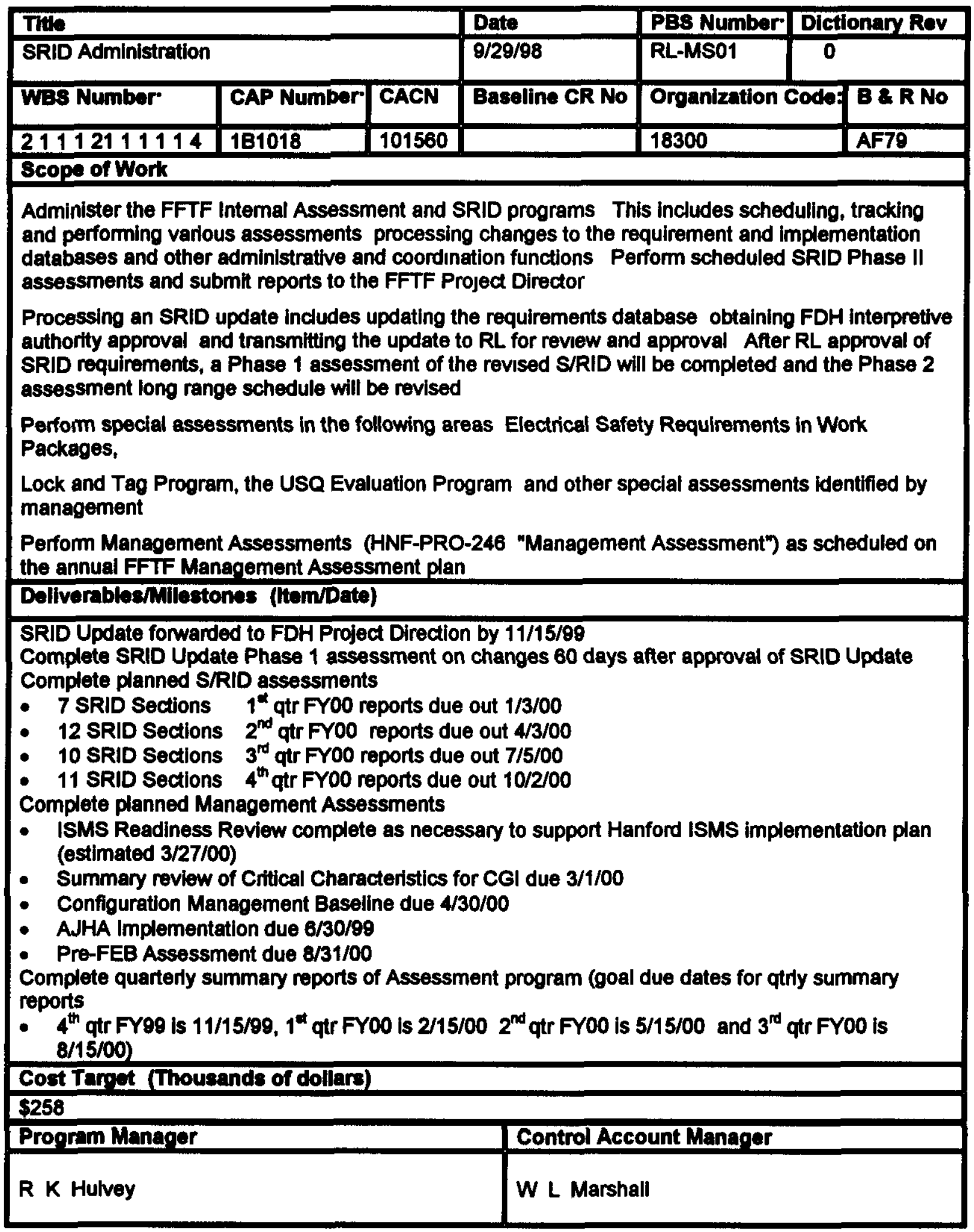




\section{Control Account Dictionary \\ Advanced Reactors Transition \\ Fast Flux Test Facility \\ WBS 2010101210101}

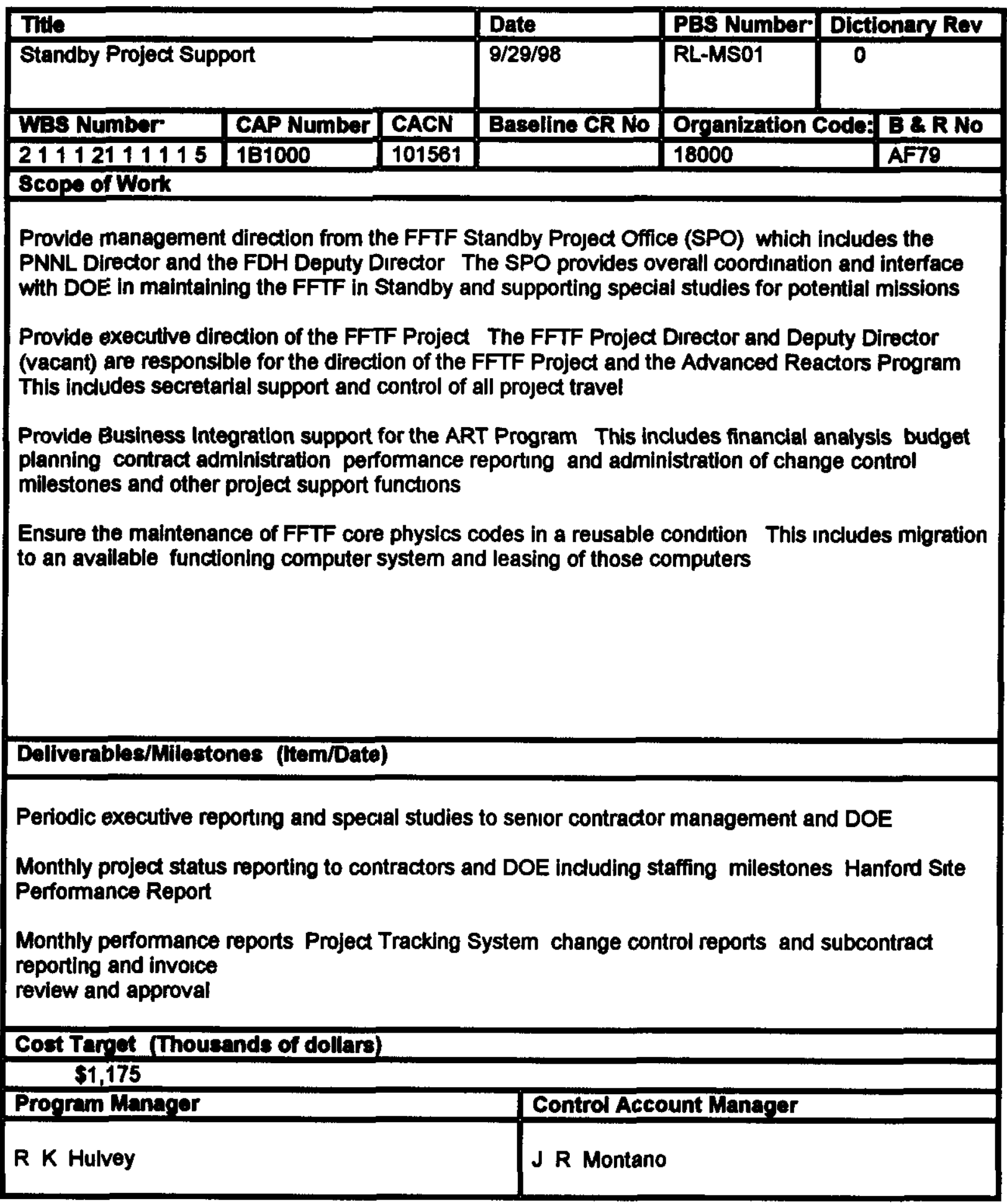


Control Account Dictionary

Advanced Reactors Transition

Fast Flux Test Facility

WBS 2010101210101

\begin{tabular}{|c|c|c|c|c|c|}
\hline \multicolumn{3}{|l|}{ Tithe } & Date & PBS Number & Dictionary Rev \\
\hline \multicolumn{3}{|c|}{ Human/Industrial Relations } & $10 / 15 / 99$ & RL-MS01 & 0 \\
\hline WB8 Number & CAP Number & CACN & Baseline CR No & Organization C & de: B\&R No \\
\hline $2111211111 \mathrm{~T}$ & $1 B 1034$ & 111910 & & 18000 & AF79 \\
\hline
\end{tabular}

Provide project human relations personnel services Provide Industrial Relations support to the FFTF project to resolve issues which may anse with bargaining unit personnel

NOTE The full scope of this work has not yet been defined and a budget has not been established This WBS Element and $\mathrm{CaCN}$ have been established to collect costs while the effects of the contractor reorganization are determined

\section{Deliverables/Milestones (Item/Date)}

No discrete deliverables

\section{Cost Tarpet (Thousands of dollars)}

$$
\text { so }
$$

Program Manager

Control Account Managor

R K Hulvey

J R Montano 


\section{Control Account Dictionary \\ Advanced Reactors Transition \\ Fast Flux Test Facility \\ WBS 2010101210101}

\begin{tabular}{|c|c|c|}
\hline Tite & Date & PBS Number Dictionany Rev \\
\hline FFTF EIS Support & $9 / 29 / 98$ & \begin{tabular}{|l|l} 
RL-MS01 & 0
\end{tabular} \\
\hline \begin{tabular}{l|l} 
WBS Number & CAP Number CACN \\
\end{tabular} & Baseline CR No & Organization Code: B \& R No \\
\hline \begin{tabular}{|l|l|l|}
211121111113 & 1B1009 & 110245 \\
\end{tabular} & & \begin{tabular}{l|l}
18300 & AF79 \\
\end{tabular} \\
\hline \multicolumn{3}{|l|}{ Scope of Work } \\
\hline \multicolumn{3}{|c|}{$\begin{array}{l}\text { Provide response to requests from the PEIS preparer for information regarding the FFTF as } \\
\text { necessary } \\
\text { The full scope of this WBS Element will be evaluated and controlled once the PEIS scope and FFTF } \\
\text { support requirements are defined }\end{array}$} \\
\hline \multicolumn{3}{|l|}{ Deliverables/Milestones (item/Date) } \\
\hline \multicolumn{3}{|l|}{ Not defined } \\
\hline \multicolumn{3}{|l|}{ Cost Taryet (Thousands of dollars) } \\
\hline \multicolumn{3}{|l|}{$\$ 320$} \\
\hline Program Manager & \multicolumn{2}{|c|}{ Control Account Manager } \\
\hline R K Hulvey & \multicolumn{2}{|l|}{ T M Burke } \\
\hline
\end{tabular}




\section{Control Account Dictionary \\ Advanced Reactors Transition \\ Fast Flux Test Facility \\ WBS 2010101210101}

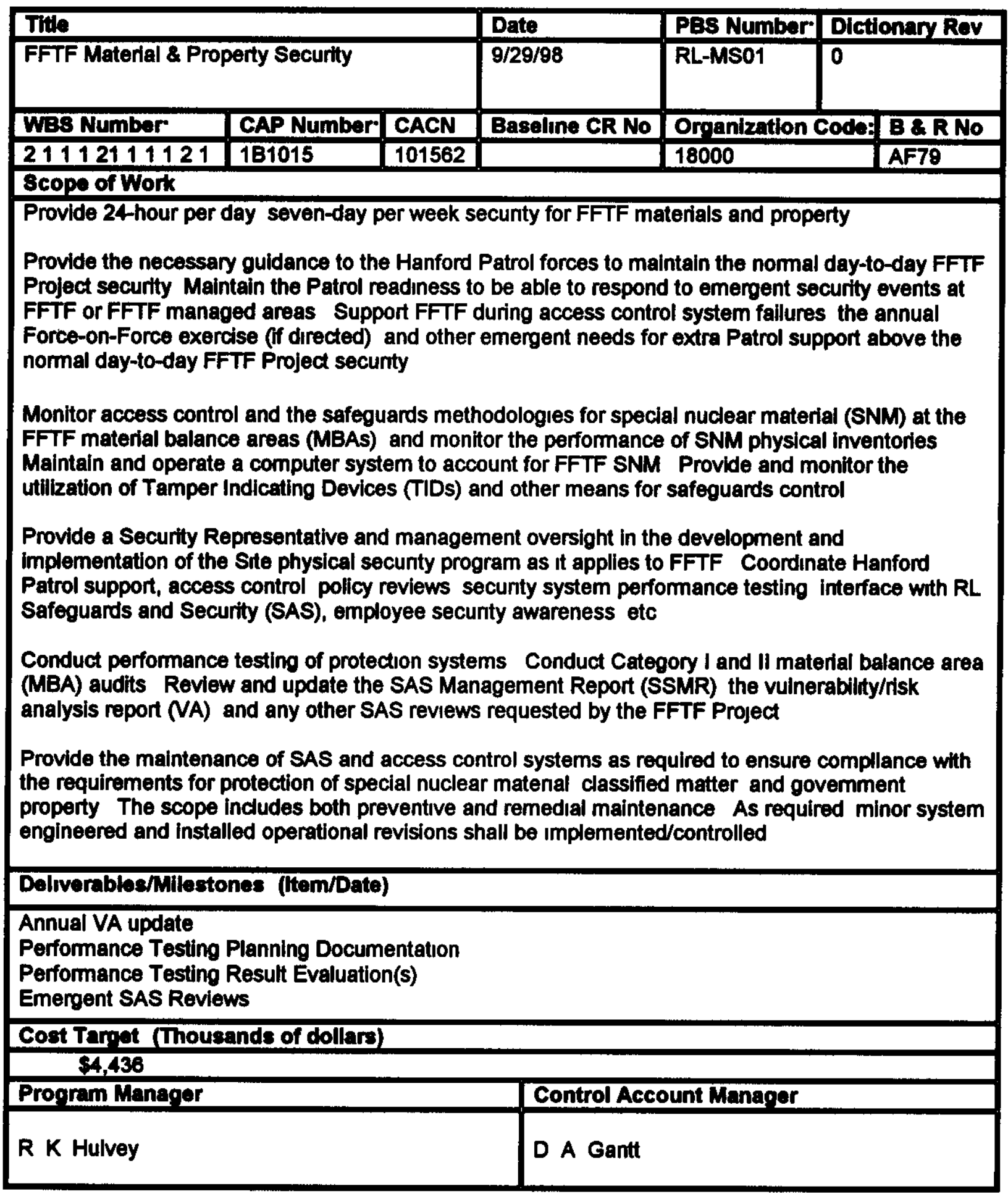




\section{Control Account Dictionary}

Advanced Reactors Transition

Fast Flux Test Facility

WBS 2010101210101

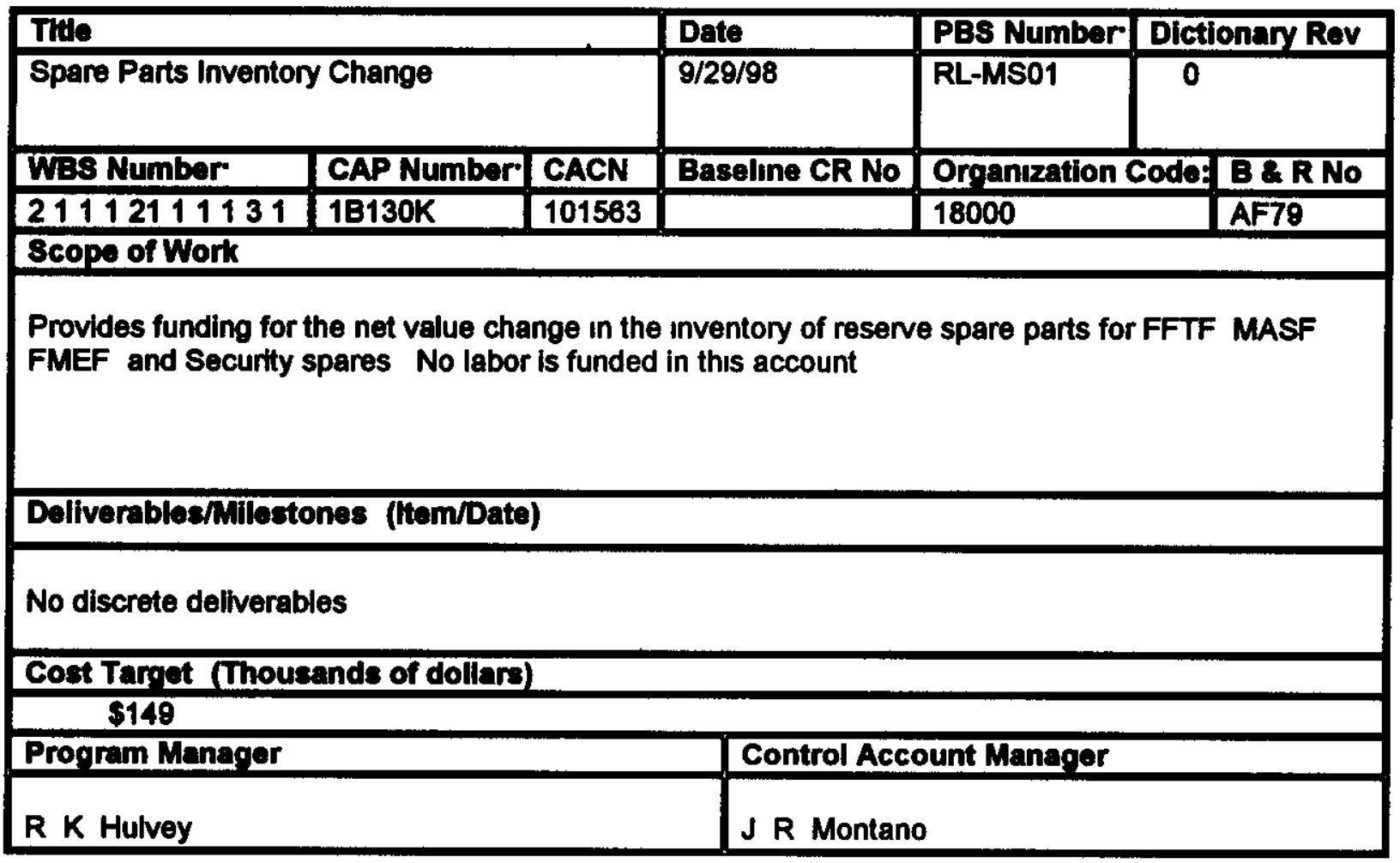

\begin{tabular}{|c|c|c|}
\hline Title & Date & PBS Number Dictionary Rev \\
\hline Spare Parts Withdrawal / Returns & 9/29/98 & \begin{tabular}{|l|l} 
RL-MS01 & 0 \\
\end{tabular} \\
\hline \begin{tabular}{l|l} 
WBS Number & CAP Number \\
\end{tabular} & Baseline CR No & \begin{tabular}{|l|l} 
Organization Code B \& R No \\
\end{tabular} \\
\hline \begin{tabular}{|l|l|l}
21112111132 & $1 B 130 L$ & 101564 \\
\end{tabular} & & \begin{tabular}{|l|l|}
18000 & AF79 \\
\end{tabular} \\
\hline \multicolumn{3}{|l|}{ Scope of Work } \\
\hline \multicolumn{3}{|c|}{$\begin{array}{l}\text { Provide funding for the net Inventory Change due to adjustments excessing loss and write-offs in } \\
\text { the inventory and reserve sub-accounts at FFTF MASF FMEF and Securtty spares No labor is } \\
\text { funded in this account }\end{array}$} \\
\hline \multicolumn{3}{|c|}{ Deliverables/Milestones (Item/Date) } \\
\hline \multicolumn{3}{|l|}{ No discrete deliverables } \\
\hline \multicolumn{3}{|l|}{ Cost Tarpot (Thousands of dollars) } \\
\hline \multicolumn{3}{|l|}{$\$ 71$} \\
\hline Program Manager & \multicolumn{2}{|c|}{ Control Account Manager } \\
\hline R K Hulvey & \multicolumn{2}{|c|}{ J R Montano } \\
\hline
\end{tabular}




\section{Control Account Dictionary Advanced Reactors Transition \\ Fast Flux Test Facility \\ WBS 2010101210101}

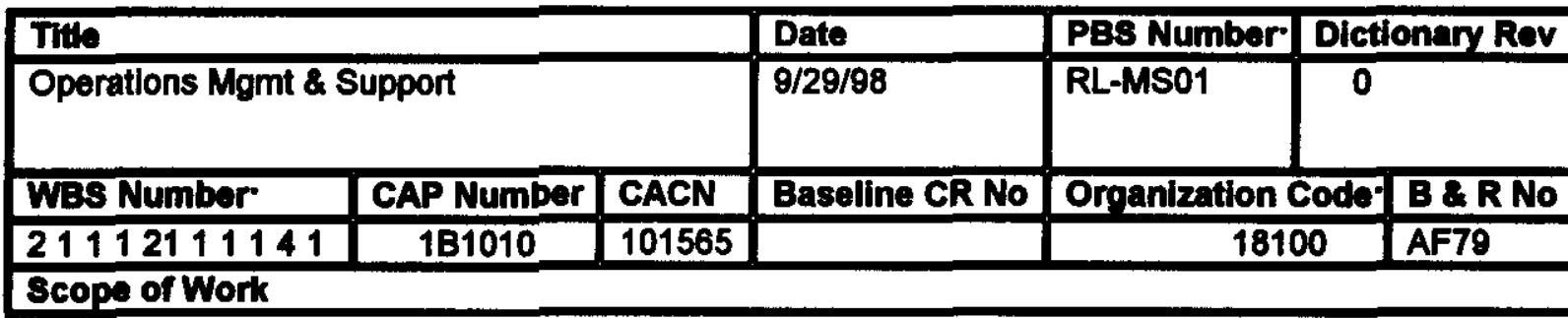

Provide program management of the FFTF Operations (Ops) group, which includes nuclear operators examination and decontamination services (EDS) operators and stationary operating engineers (SOE) Conduct general activities including staff meetings safety meetings daily reports, etc

Provide Ops staff general training including HGET PIC Radıation Worker, etc and faclity specific training including watchstation qualificatıon new hıre traınıng ERT training and operations drills

Provide around-the-clock seven-day per week operation of FFTF plant systems and equipment and emergency responder capability Perform log takıng Conduct of Operatıons Assessments tickle file items SC/EC surveillances housekeeping tours FS performance and safety equipment checks

Provide Lock and Tag control, Jumper/Lffed Lead control and qualified plant personnel to support the Work Control Center Perform special Operations Projects as assigned by the management team

\section{Deliverables/Milestones (item/Date)}

Conduct 10 Operations drills per month

Support completion of workphase 00-1 Health of the Facility workscope, RL milestone B10-00-000 / 1/31/00

Support completion of workphase 00-2 "Health of the Facillty" workscope, RL milestone B10-00-001 $15 / 31 / 00$

Support completion of workphase 00-3 "Health of the Facility" workscope, RL milestone B10-00-002 1 9/29/00

\section{Cost Tanyet (Thousands of dollars)}

$$
\$ 8,055
$$




\section{Control Account Dictionary Advanced Reactors Transition \\ Fast Flux Test Facility \\ WBS 2010101210101}

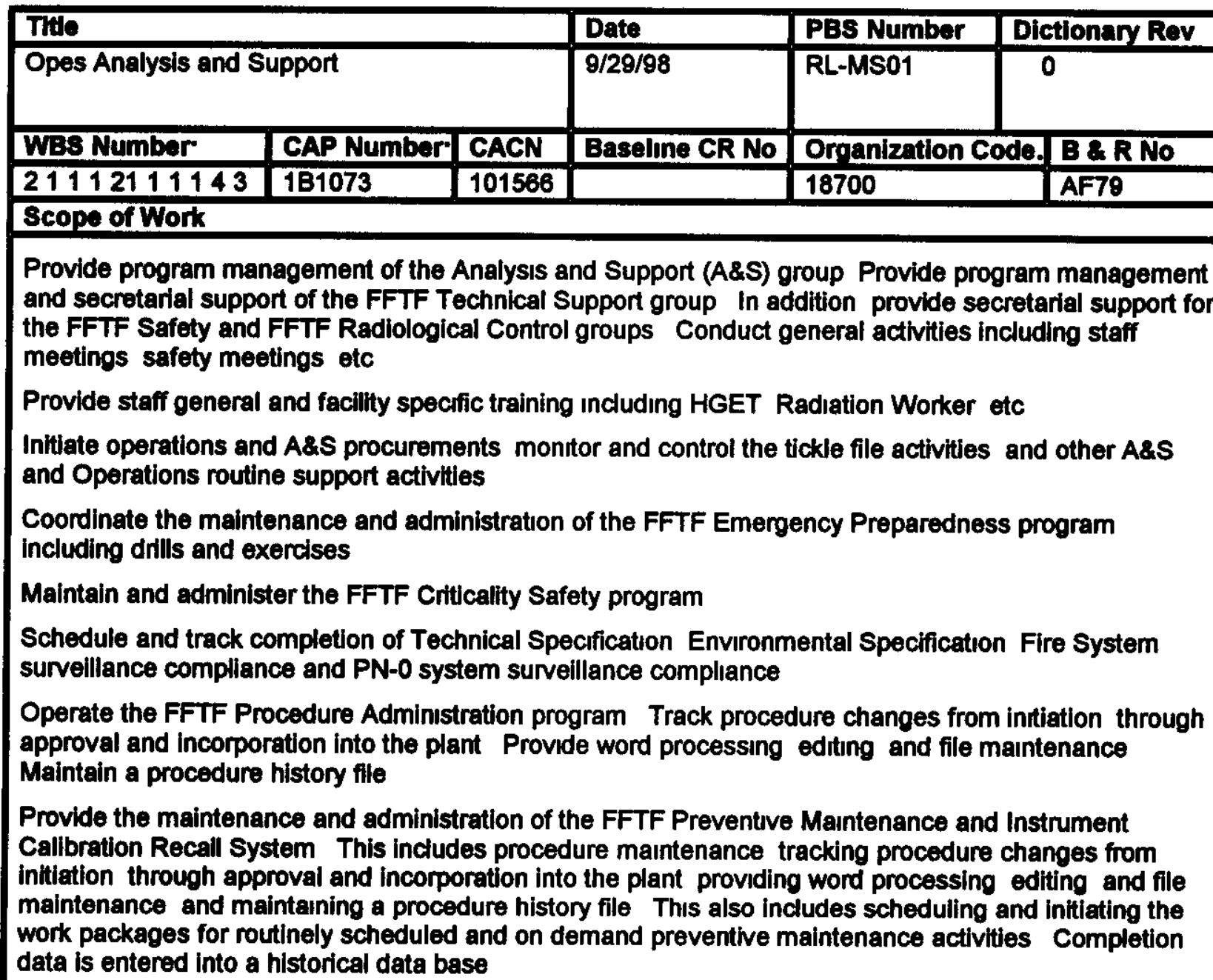


HNF-SD-FF-SSP-050

Rev 8, Page 41

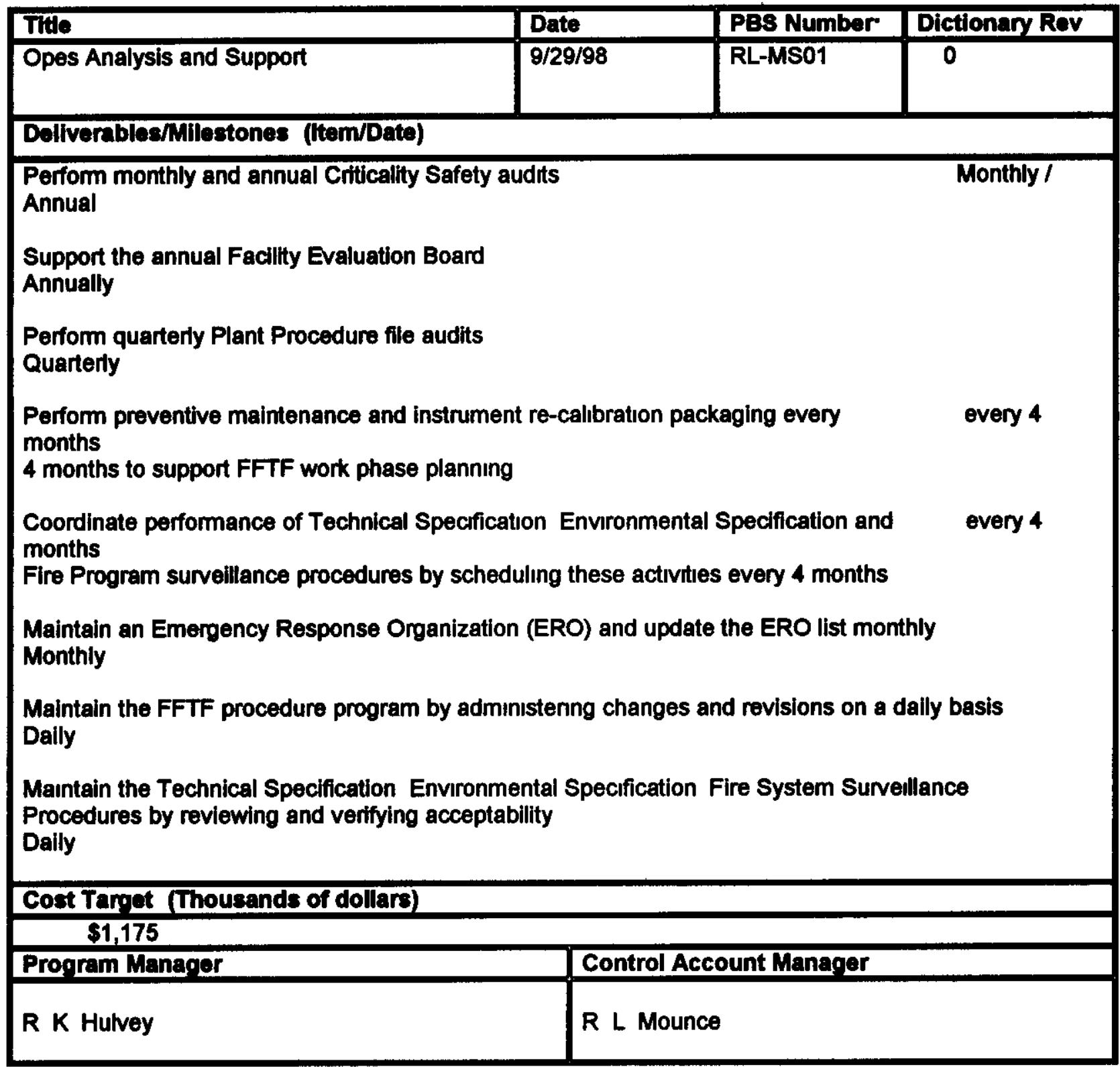




\section{Control Account Dictionary \\ Advanced Reactors Transition}

Fast Flux Test Facility

WBS 2010101210101

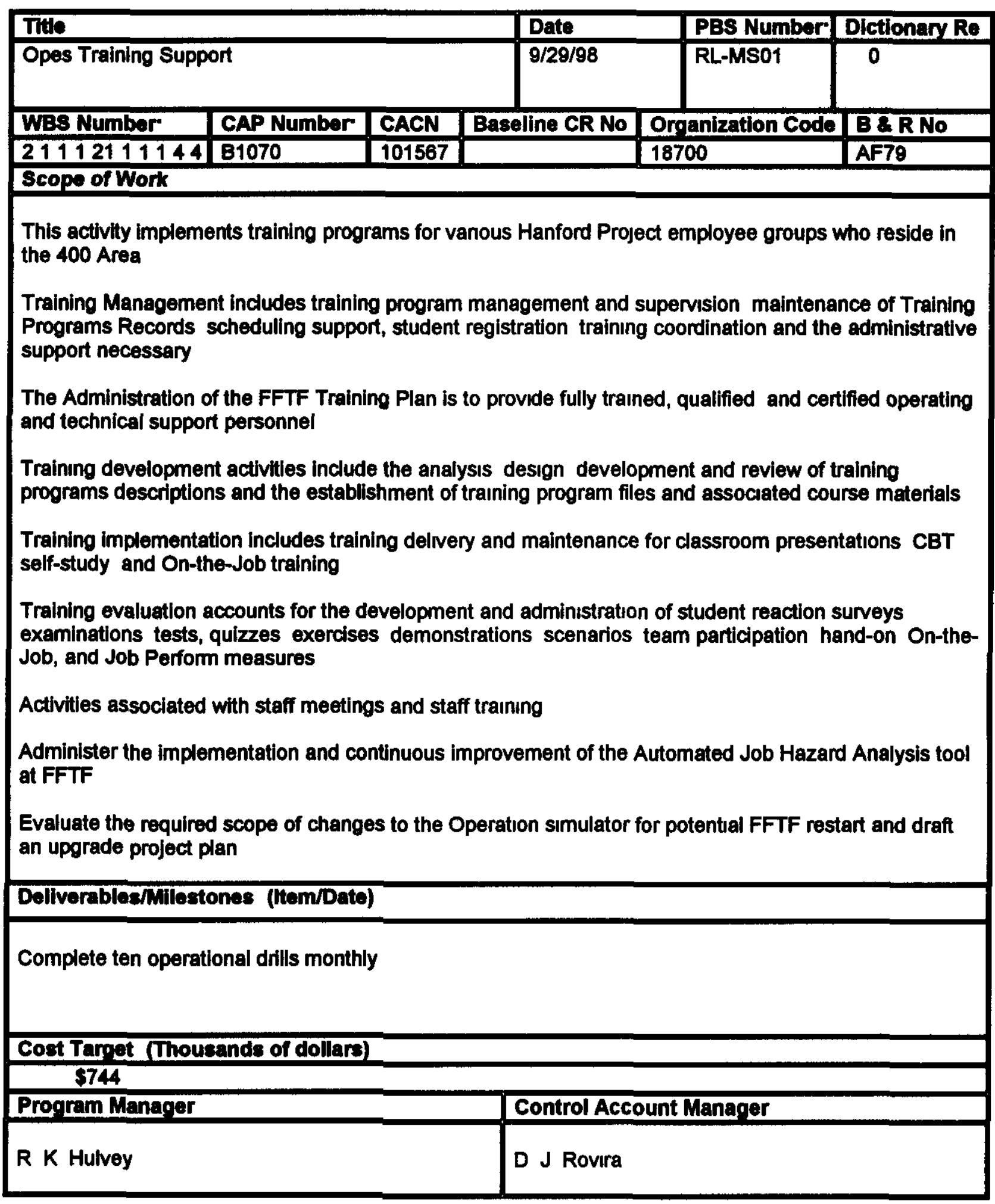




\section{Control Account Dictionary \\ Advanced Reactors Transition \\ Fast Flux Test Facility \\ WBS 2010101210101}

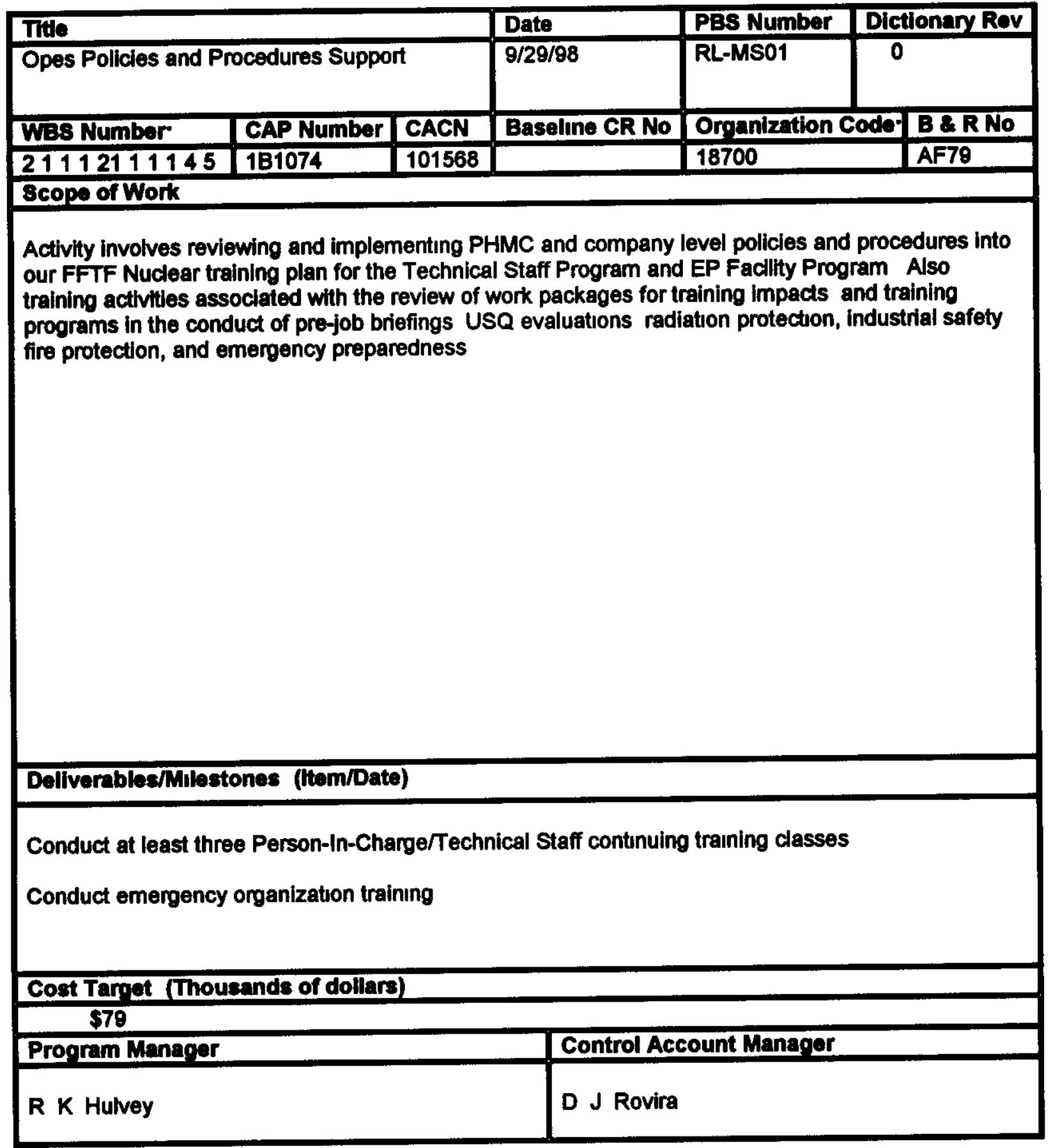




\section{Control Account Dictionary}

Advanced Reactors Transition

Fast Flux Test Facility

WBS 2010101210101

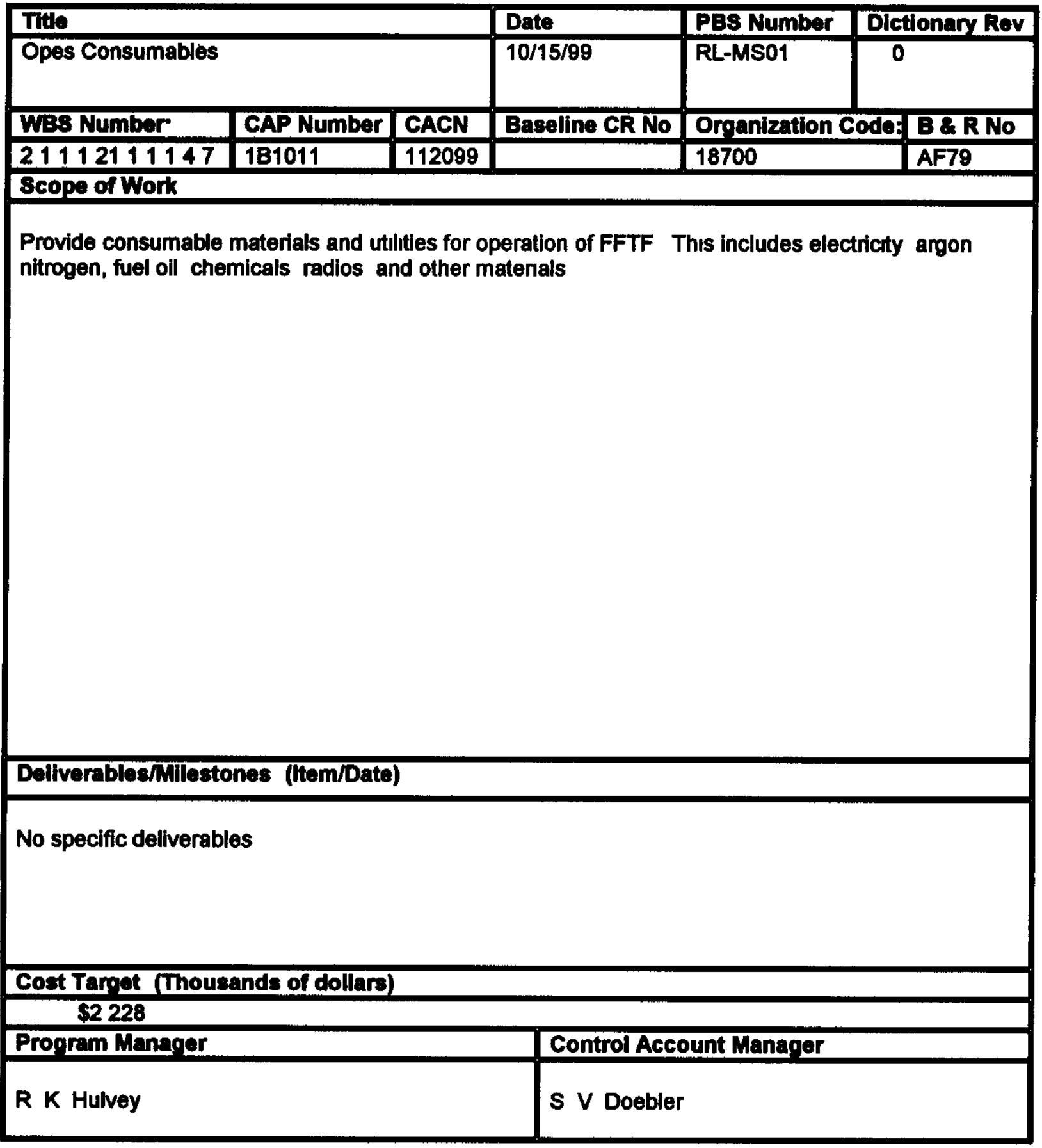




\section{Control Account Dictionary Advanced Reactors Transition \\ Fast Flux Test Facility WBS 2010101210101}

\begin{tabular}{|c|c|c|c|c|c|}
\hline \multicolumn{3}{|l|}{ Tite } & Date & PBs Number & Dictionary Rov \\
\hline \multicolumn{3}{|l|}{ SOE Plant Operations } & 9/29/98 & RL-MS01 & 0 \\
\hline WBS Number: & CAP Number: & CACN & Baseline CR No & Organization C & ode. B \& R No \\
\hline 21112141148 & $1 \mathrm{B1012}$ & 112100 & & 18700 & AF79 \\
\hline
\end{tabular}

Provide program management of the statıonary operating engineers (SOE) Conduct general activities including staff meetings safety meetings dally reports, etc

Provide SOE staff general training including HGET PIC Radiation Worker etc and facility specific training including watchstation qualification new hire training and operations drills

Provide around-the-clock seven-day per week operation of FFTF plant systems and equipment and emergency responder capability Perform log takıng Conduct of Operatıons Assessments tickle file items FC surveillances housekeeping tours and safety equipment checks Landlord Facility Operations

Provide Lock and Tag control, Jumper/Lfted Lead control and Landlord Confined Space Management Perform special Operations Projects as assigned by the management team

Deliverables/Milestones (Item/Date)

There are no discrete deliverables

Cost Tarpet (Thousands of dollars)

$\$ 714$

\begin{tabular}{l|l} 
Program Manager & Control Account Manager \\
\hline
\end{tabular}

R K Hulvey

S V Doebler 


\section{Control Account Dictionary \\ Advanced Reactors Transition \\ Fast Flux Test Facility \\ WBS 2010101210101}

\begin{tabular}{|c|c|c|}
\hline Thite & Date & PBS Number \\
\hline EDS Plant Operations & $10 / 15 / 99$ & RL-MS01 \\
\hline WBS Number $\quad$ CAP Number CACN & Baseline CR No & Organization Code. B \& R No \\
\hline \begin{tabular}{|l|l|l|l|l|l|l|l|l|}
2111211149 & 181013 & 1101 \\
\end{tabular} & & \begin{tabular}{|l|l}
18700 & AF79 \\
\end{tabular} \\
\hline \multicolumn{3}{|l|}{ Scope of Work } \\
\hline \multicolumn{3}{|c|}{$\begin{array}{l}\text { Provide program management of the FFTF examination and decontamination services (EDS) } \\
\text { operators Conduct general activities including staff meetings, safety meetings daily reports etc } \\
\text { Provide EDS Ops staff general training including HGET PIC, Radiation Worker etc and facility } \\
\text { specific training including watchstation qualification new hire training ERT training and operations } \\
\text { drills } \\
\text { Perform log taking Conduct of Operations Assessments tickle file items, SC/EC surveillances, } \\
\text { housekeeping tours FS performance and safety equipment checks } \\
\text { Provide Lock and Tag control, and qualified EDS personnel to support the Work Control Center } \\
\text { Perform special Operations Projects as assigned by the management team }\end{array}$} \\
\hline \multicolumn{3}{|l|}{ Deliverables/Millestones (Item/Date) } \\
\hline \multicolumn{3}{|l|}{ No discrete deliverables } \\
\hline \multicolumn{3}{|l|}{ Cost Tarret (Thousands of dollars) } \\
\hline \multicolumn{3}{|l|}{$\$ 503$} \\
\hline Program Manager & \multicolumn{2}{|c|}{ Control Account Manager } \\
\hline R K Hulvey & \multicolumn{2}{|l|}{ S V Doebler } \\
\hline
\end{tabular}




\section{Control Account Dictionary \\ Advanced Reactors Transition \\ Fast Flux Test Facility \\ WBS 2010101210101}

\begin{tabular}{|c|c|c|c|c|c|}
\hline Thite & & & Date & PBS Number & Dictionary Rev \\
\hline Radiological Manag & nent Support & & $9 / 29 / 98$ & RL-MS01 & 0 \\
\hline WBS Number & CAP Number & CACN & Baseline CR No & Organization C & de' B \& R No \\
\hline 21112111151 & 181045 & 101569 & & 18500 & AF79 \\
\hline
\end{tabular}

Provide program management of the 400 Area Radiological Control group Conduct general activities including staff meetings safety meetıngs monthly reports etc

Complete staff general and facility specific tranıng includıng HGET Radiation Worker DOE Radiological Control Technician training specialized training through HAMMER otc

Track and trend performance data including radıological problem reports and radiation survey reports Provide management oversight of radiological controls operations Support the 400 Area ALARA and Pollution Prevention Council Perform radiological controls SRIDs assessments Complete verification and validation of revised 10 CFR 835 requirements

Perform required radiological surveys on a routine daly weekly monthly, and as required basis to support the operation and maintenance activities of the FFTF Provide line support for procedure and work instruction development to ensure proper implementation of radıological controls participate in AJHA development as required Provide special Radıologıcal Work Permits when required Provide radiological support for work evolutions

Provide calibrated portable radiological monitonng instrumentation to support FFTF operations and maintenance activitles (Calibrations are normally performed by PNNL under contract Waste Management Northwest provides radiological shipping records for shipment of sources to PNNL for calibration )

Deliverables/Millestones (tiem/Date)

Complete routine health physics surveillances

\begin{tabular}{|l|l|}
\hline Cost Target (Thousands of dollars) \\
\hline S989 & Control Account Manager \\
\hline Program Manager & L A Nelsen \\
\hline R K Hulvey & \\
\hline
\end{tabular}


HNF-SD-FF-SSP-050

Rev 8, Page 48

\section{Control Account Dictıonary \\ Advanced Reactors Transition \\ Fast Flux Test Facility \\ WBS 2010101210101}

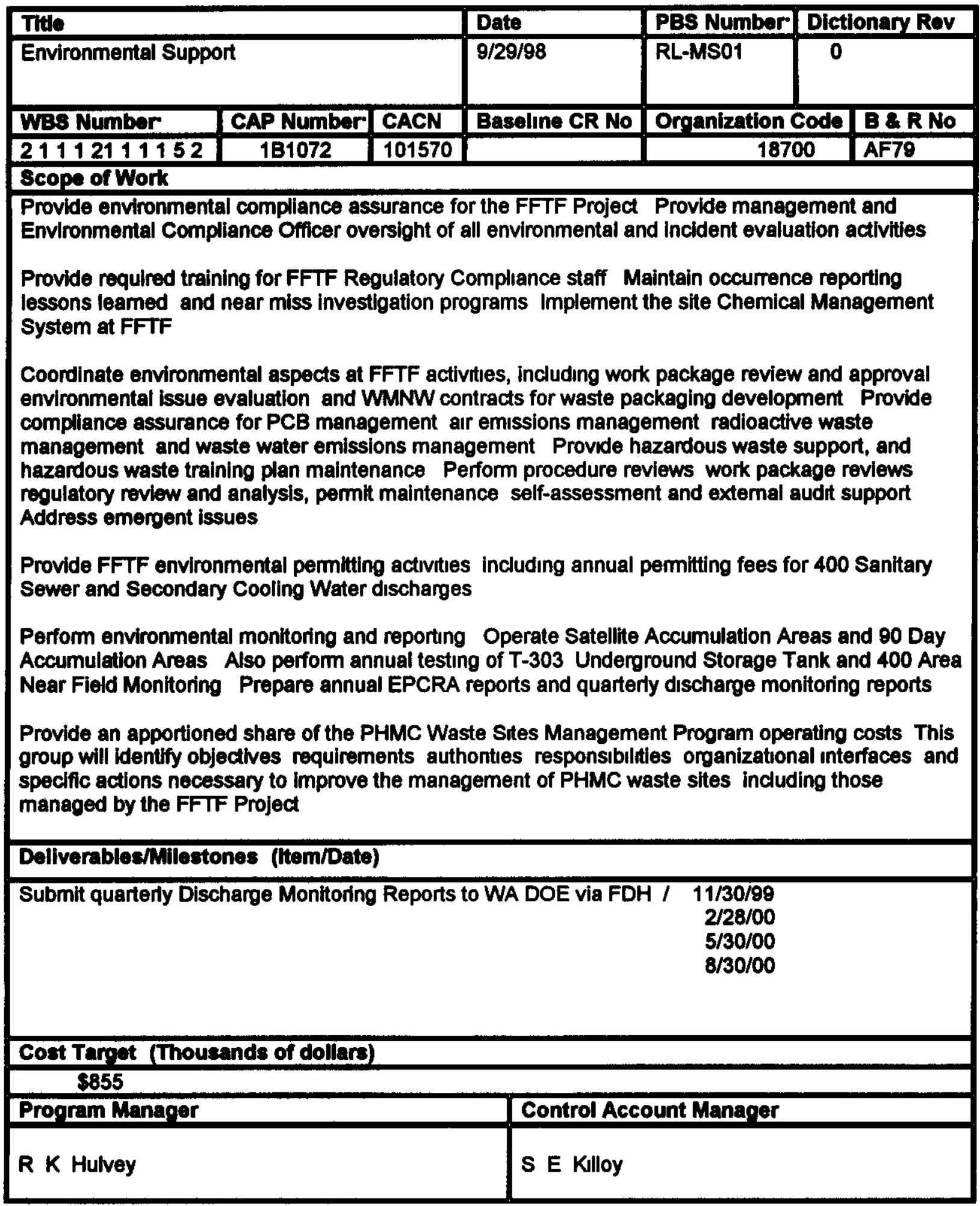




\section{Control Account Dictionary}

Advanced Reactors Transition

Fast Flux Test Facility

WBS 2010101210101

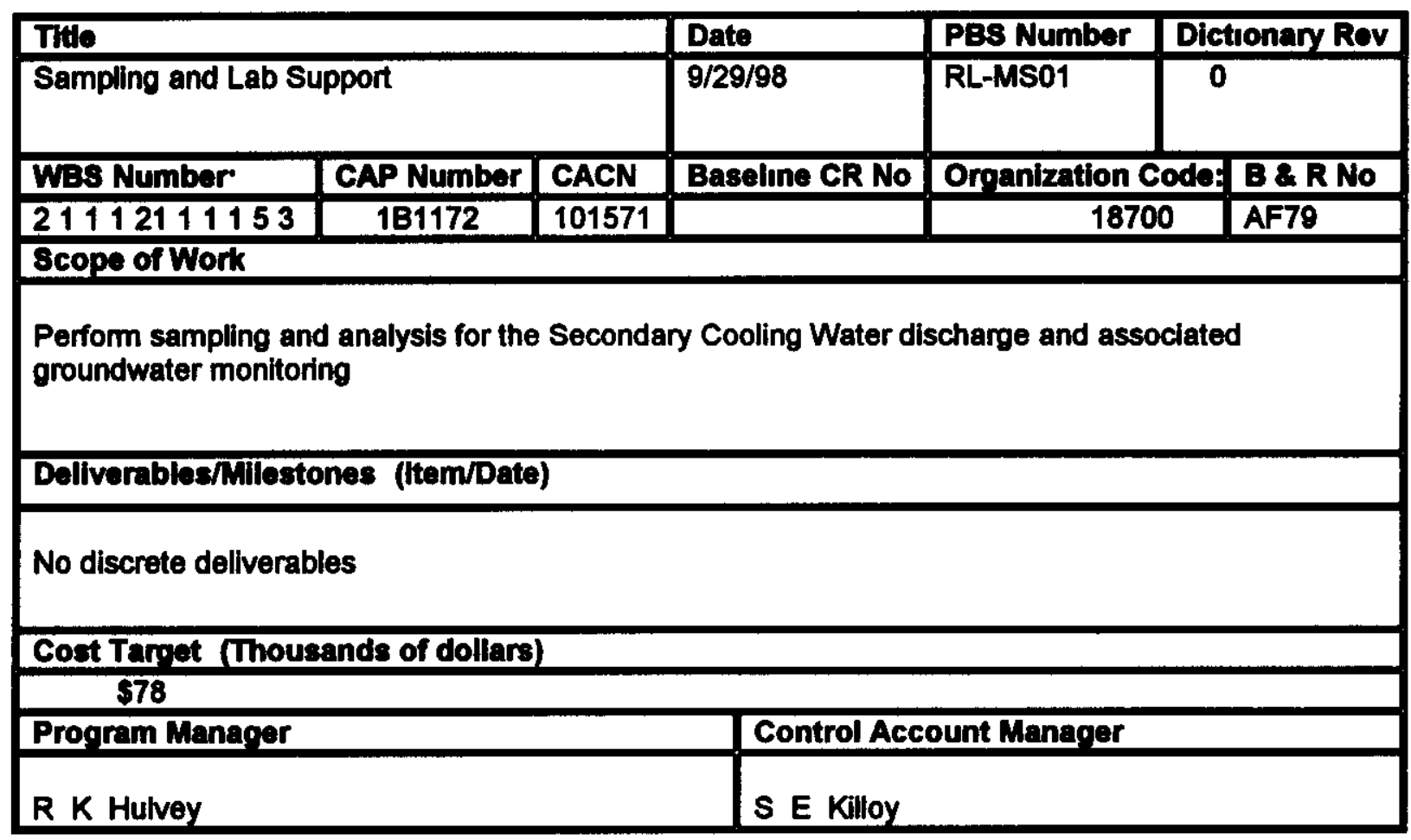

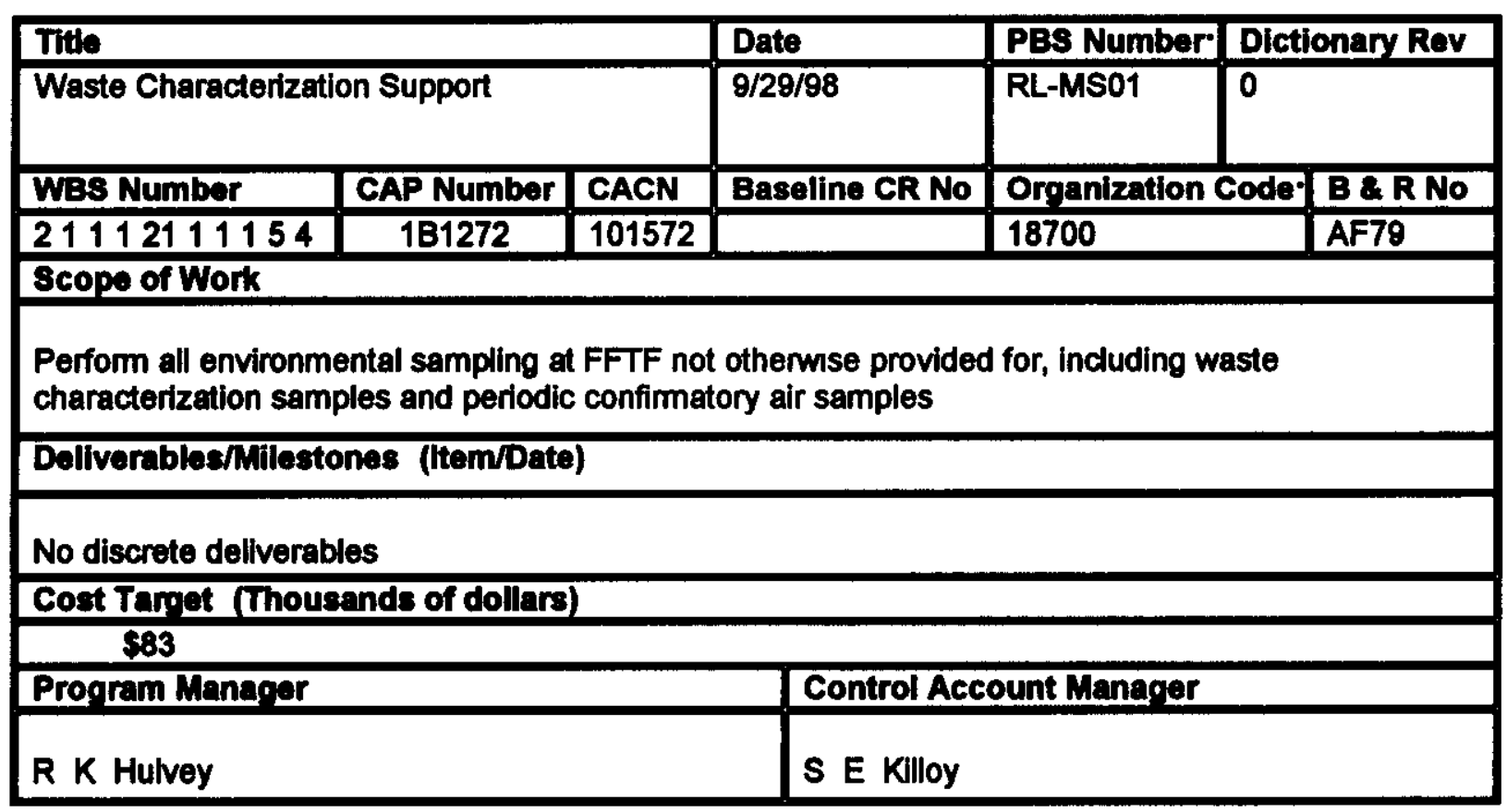




\section{Control Account Dictionary \\ Advanced Reactors Transition \\ Fast Flux Test Facility \\ WBS 2010101210101}

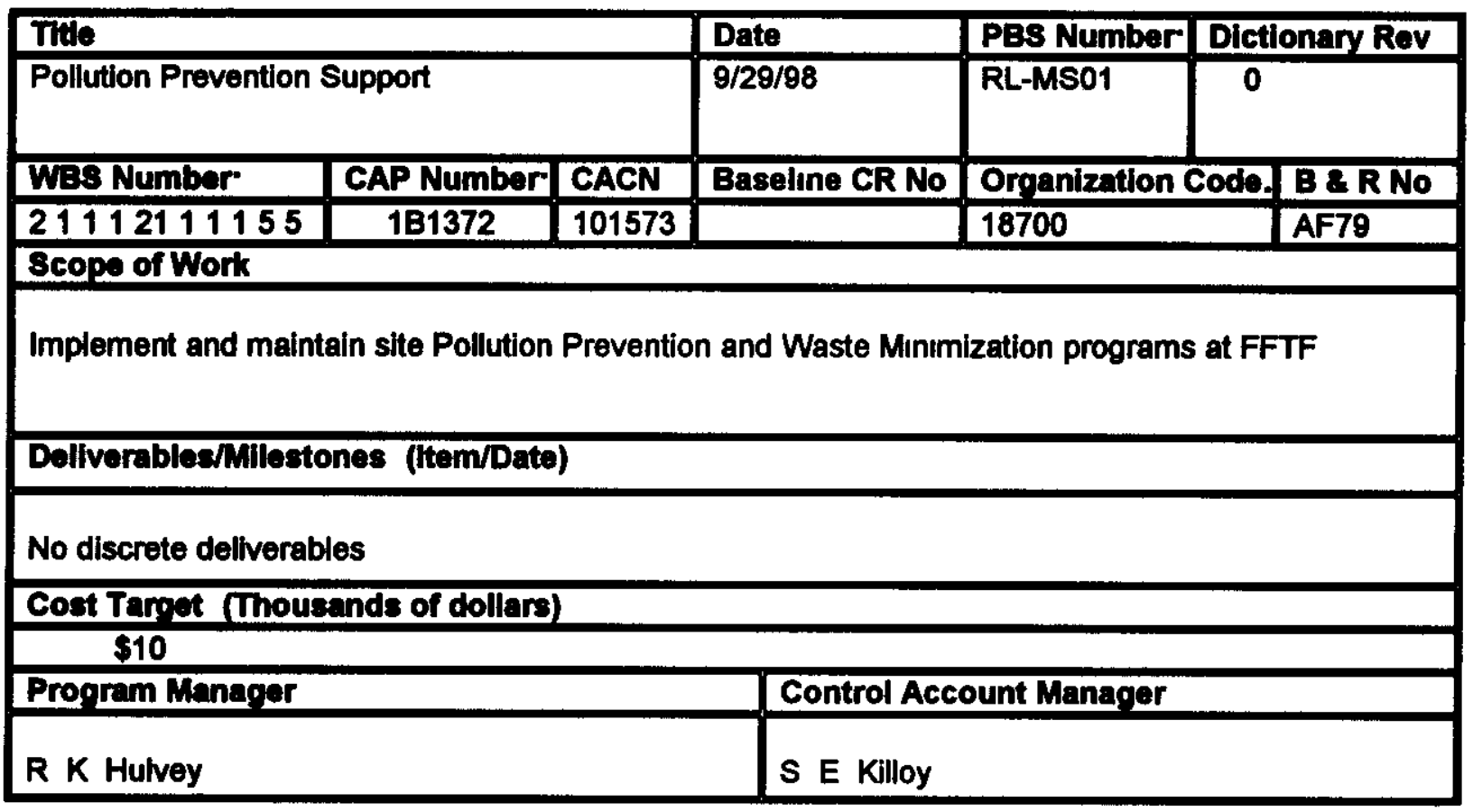

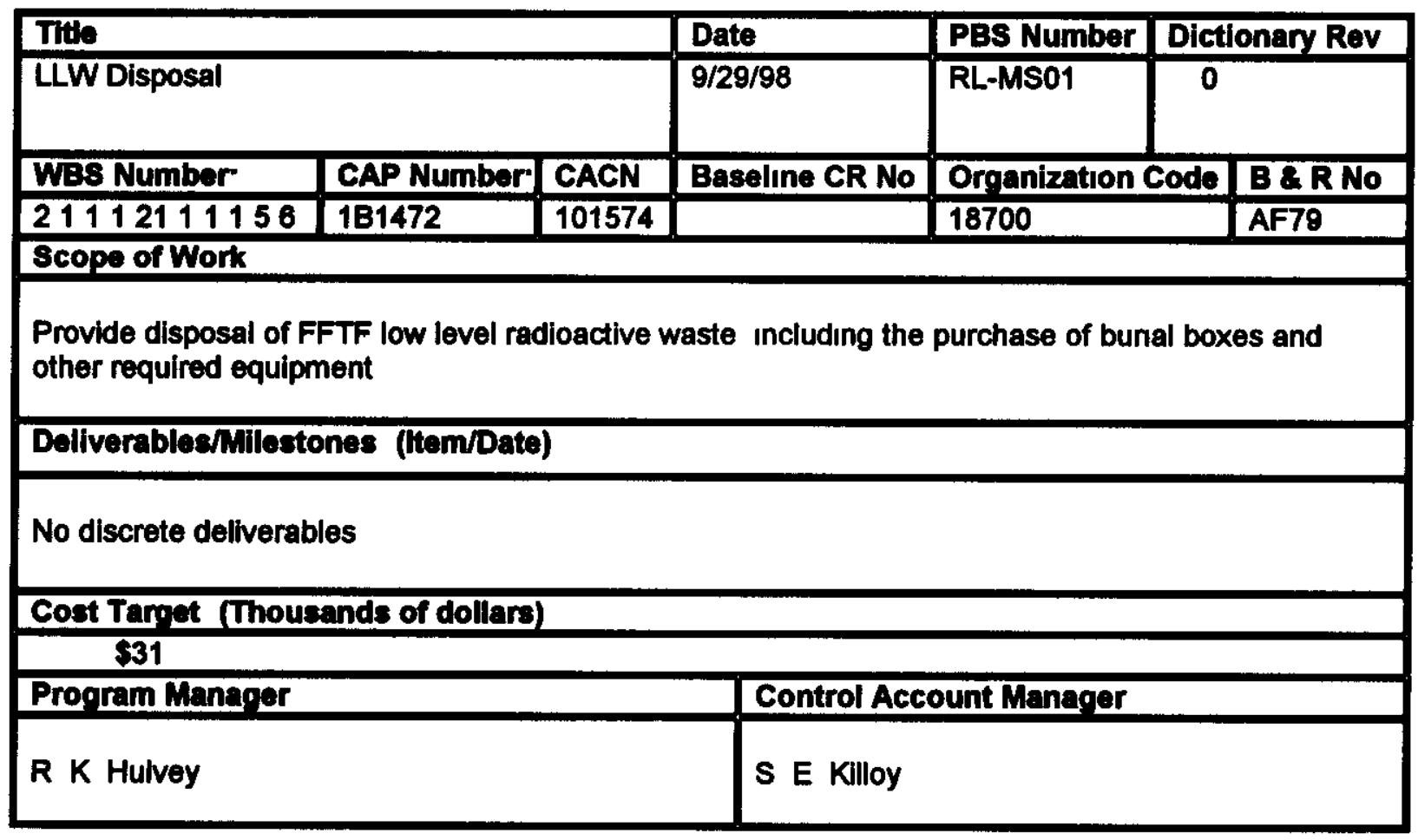




\section{Control Account Dictionary \\ Advanced Reactors Transition}

Fast Flux Test Facility

WBS 2010101210101

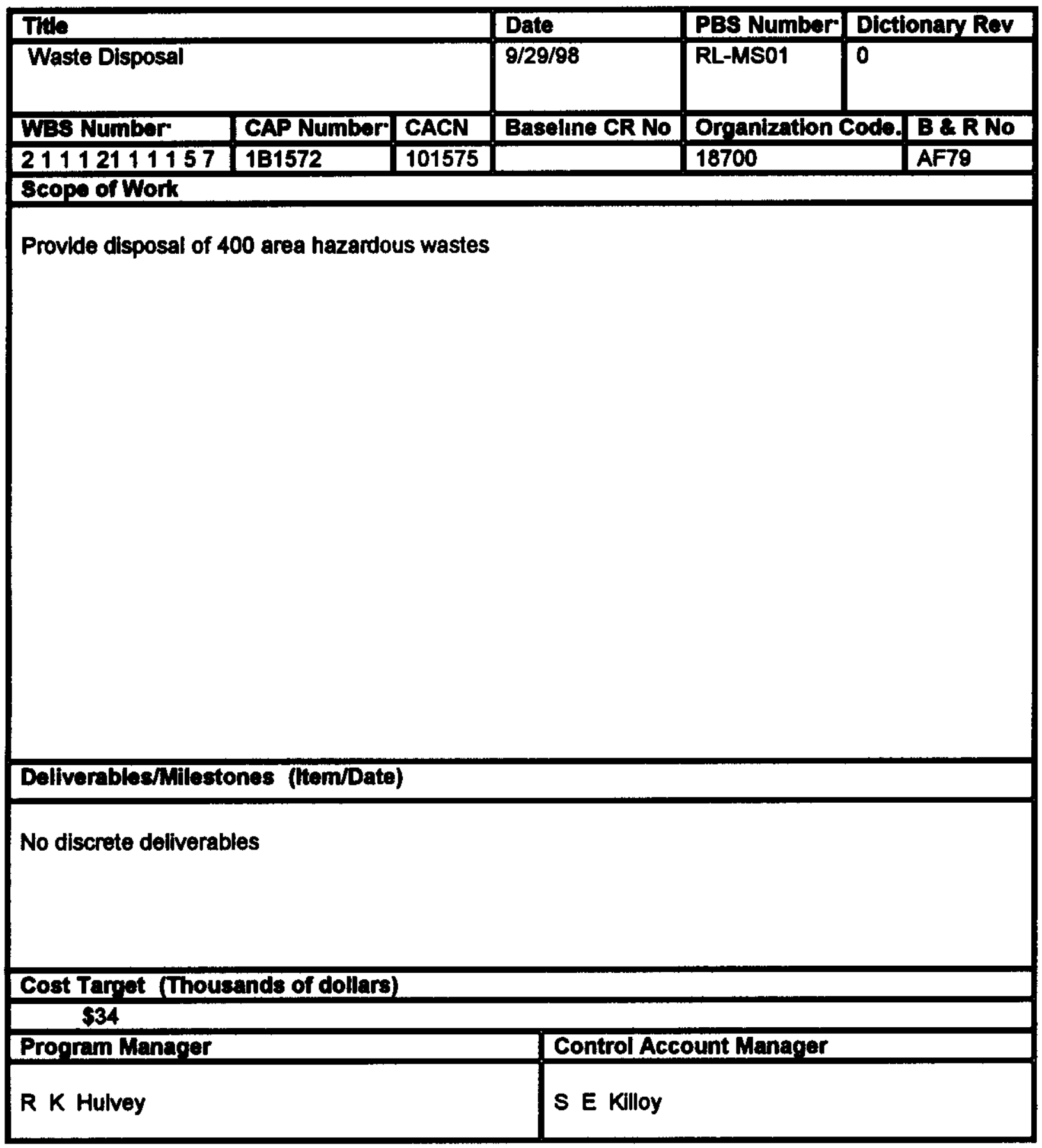




\section{Control Account Dictionary Advanced Reactors Transition \\ Fast Flux Test Facility \\ WBS 2010101210101}

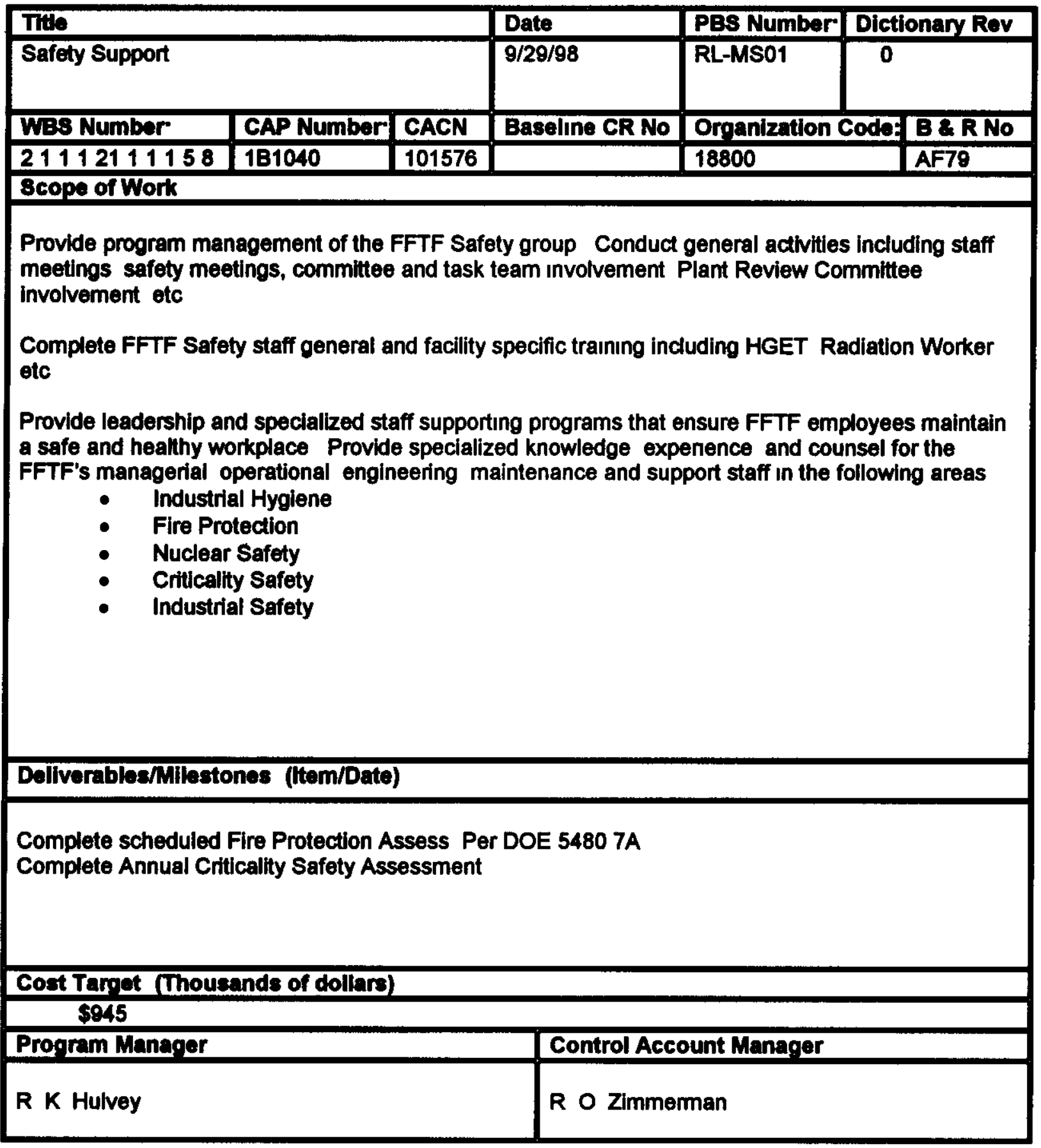




\section{Control Account Dictionary Advanced Reactors Transition \\ Fast Flux Test Facility WBS 2010101210101}

\begin{tabular}{|c|c|c|c|c|c|}
\hline \multirow{2}{*}{\multicolumn{3}{|c|}{$\begin{array}{l}\text { Titie } \\
\text { Quality Assurance }\end{array}$}} & Date & PBS Number & Dictionary Rev \\
\hline & & & $9 / 29 / 98$ & RL-MS01 & 0 \\
\hline WBs Number & CAP Number & CACN & Baseline CR No & \multicolumn{2}{|c|}{ Organization Code: B \& R No } \\
\hline 21112111159 & $1 \mathrm{~B} 1040$ & 101577 & & 18400 & AF79 \\
\hline
\end{tabular}

Provide program management of the FFTF Quality Assurance group Conduct general activities including staff meetings safety meetıngs Plant Review Committee involvement etc

Complete FFTF QA staff general and faclity specific traıning including HGET Radiation Worker, etc

Provide leadership and specialized Quality Assurance/Quality Control support to the FFTF staff for compliance with the QA rule and Quality Assurance program This includes self assessments training, document review and inspection activities

Review and approve quality affectıng FFTF operatıng procedures work packages and material procurements

Conduct self assessments of FFTF performance

Perform inspections of quality affecting maintenance and modification activities in the FFTF

Deliverables/Milestones (Item/Date)

Conduct 24 survellances to determine areas for improvement and to assess compliance with the requirements imposed on the facility

Cost Tarret (Thousands of dollars) $\$ 502$

Program Manager Control Account Manager

R K Hulvey

R O Zimmerman 


\section{Control Account Dictionary Advanced Reactors Transition \\ Fast Flux Test Facility \\ WBS 2010101210101}

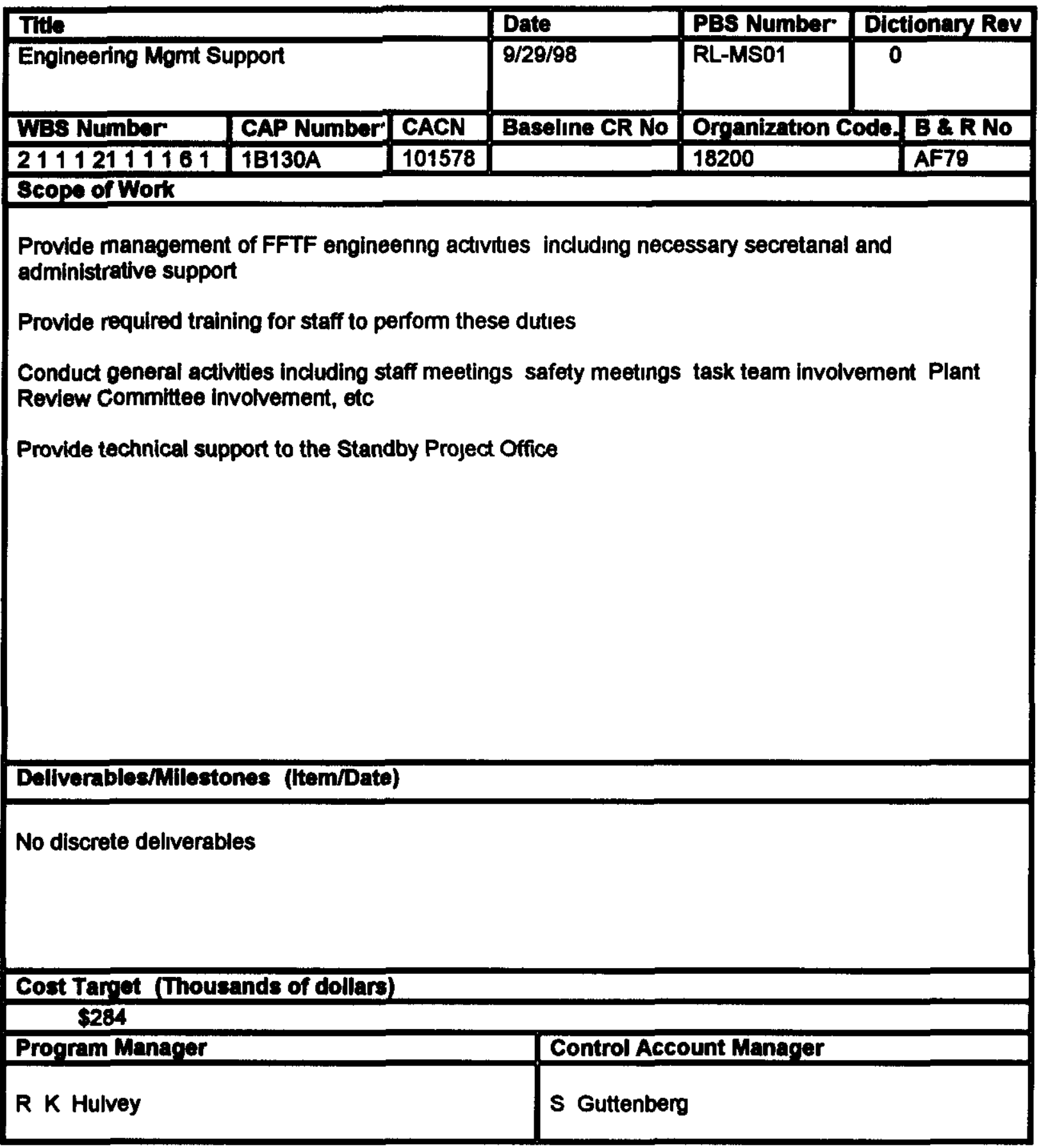




\section{Control Account Dictionary Advanced Reactors Transition \\ Fast Flux Test Facility \\ WBS 2010101210101}

\begin{tabular}{|c|c|c|}
\hline The & Date & PBS Number' Dictionary Rov \\
\hline Aux Sys Electrical Eng Support & 9/29/98 & RL-MS01 \\
\hline CAP Number CACN & Baseline CR No & Organization Code. B \& R No \\
\hline 21112111162 & & \begin{tabular}{|l|l}
18200 & AF79 \\
\end{tabular} \\
\hline \multicolumn{3}{|l|}{ Scope of Work } \\
\hline \multirow{2}{*}{\multicolumn{3}{|c|}{$\begin{array}{l}\text { Provide program management of the FFTF Auxiliary Systems Electrical Engineering (ASEE) group } \\
\text { ASEE is responsible for providing engineenng support for Over } 110 \text { systems for FFTF Plant MASF, } \\
400 \text { Area Landlord, and FMEF Significant FFTF Plant MASF Landlond, and FMEF systems ASEE } \\
\text { is responsible for are electrical distribution lightıng communications fire protection HVAC sodium } \\
\text { system trace heat sodium level and leak detection inert gas supply and distribution sodium } \\
\text { sampling and monitoring radiation monitoring and plant annunciators } \\
\text { Complete ASEE staff general and facility specific training including HGET PIC Radiation Worker, } \\
\text { Electrical Safety etc }\end{array}$}} \\
\hline & & \\
\hline \multicolumn{3}{|c|}{$\begin{array}{l}\text { Provide cognizant engineer and design authonty support for FFTF preventative maintenance (PM) } \\
\text { activities, including review and revision of PM categories, frequencies and procedures and evaluation } \\
\text { of data obtained from PM activities Provide support to FFTF corrective maintenance activities, } \\
\text { Including preparation of corrective maintenance and modification work packages and ondering of } \\
\text { required materials As required supervise fieldwork (i e Person in Charge activities) Prepare } \\
\text { review and approve FFTF operating procedures related to assigned ASEE systems Support the } \\
\text { achievement of the health of the facility maintenance milestones Conduct general activities } \\
\text { including staff meetings safety meetings monthly reports etc }\end{array}$} \\
\hline \multicolumn{3}{|c|}{$\begin{array}{l}\text { Obtain outside services for maintaining the FFTF communications systems and to provide National } \\
\text { Electrical Code interpretations and inspections }\end{array}$} \\
\hline \multicolumn{3}{|c|}{$\begin{array}{l}\text { Provide secretarial support including preparation and issuance of correspondence and reports } \\
\text { routing and tracking work packages takıng messages scheduling trainıng prepanng monthly } \\
\text { performance data maintaining the engineenng department required reading log and the design } \\
\text { authority matrix, processing modification packages during ECN release and closeout supply } \\
\text { procurement administrative support for other FFTF project groups as required and perform as } \\
\text { project point-of-contact for several PHMC procedures }\end{array}$} \\
\hline \multicolumn{3}{|c|}{ Deliverables/Milestones (ftem/Date) } \\
\hline \multicolumn{3}{|c|}{$\begin{array}{l}\text { Support completion of workphase 00-1 Health of the Facility" workscope, RL milestone B10-00-000 } \\
\text { / } 1 / 31 / 00 \\
\text { Support completion of workphase 00-2 Health of the Facility" workscope RL milestone B10-00-001 } \\
\text { / } 5 / 31 / 00 \\
\text { Support completion of workphase 00-3 Health of the Facilty" workscope RL milestone B10-00-002 } \\
19 / 28 / 00\end{array}$} \\
\hline \multicolumn{3}{|c|}{ Cost Tareet (Thousands of dollars) } \\
\hline \multicolumn{3}{|l|}{$\$ 1,260$} \\
\hline Program Manager & \multicolumn{2}{|c|}{ Control Account Manager } \\
\hline R K Hulvey & \multicolumn{2}{|l|}{ S H Crow } \\
\hline
\end{tabular}




\section{Control Account Dictıonary \\ Advanced Reactors Transition \\ Fast Flux Test Facility \\ WBS 2010101210101}

\begin{tabular}{|c|c|c|}
\hline Titte & Date & PBS Number Dictionary Rev \\
\hline Mechanical Eq \& Inservice Support & $9 / 29 / 98$ & \begin{tabular}{l|l} 
RL-MSO1 & 0
\end{tabular} \\
\hline CAP Number CACN & Baseline CR No & $\begin{array}{l}\text { Organization Code } \mathrm{B} \& \mathrm{R} \text { No } \\
\end{array}$ \\
\hline 21112111163 & & \begin{tabular}{l|l}
18200 & AF79 \\
\end{tabular} \\
\hline \multicolumn{3}{|l|}{ 8cope of Work } \\
\hline \multicolumn{3}{|c|}{$\begin{array}{l}\text { Provide program management of the FFTF Mechanical Engineenng and In-service Inspection (MEII) } \\
\text { group Conduct general activities including staff meetings safety meetings monthly reports etc } \\
\text { Complete MEII staff general and facility specific trainıng including HGET, PIC Radiation Worker etc } \\
\text { Prepare, review and approve FFTF operatıng procedures related to assigned mechanical systems } \\
\text { and in-service inspection } \\
\text { Provide support to FFTF preventative maintenance (PM) and In-service Inspection (SISI) activities } \\
\text { including review and revision of PM categories frequencies and procedures and evaluation of data } \\
\text { obtained from PM and SISI activities Provide support to FFTF corrective maintenance activities } \\
\text { including preparation of corrective maintenance and modification work packages and ordering of } \\
\text { required materials As required supervise fieldwork (i e Person in Charge activities) Support the } \\
\text { achievement of the "health of the facility maintenance milestones } \\
\text { Provide Cognizant Engineer / Design Authority function for assigned systems and components }\end{array}$} \\
\hline \multicolumn{3}{|l|}{ Deliverablea/nilestones (Item/Date) } \\
\hline \multicolumn{3}{|c|}{$\begin{array}{l}\text { Issue Annual SISI report by } 3 / 31 / 00 \\
\text { Support completion of workphase 00-1 Health of the Facilty workscope RL milestone B10-00-000 } \\
\text { / } 1 / 31 / 00 \\
\text { Support completion of workphase } 00-2 \text { Health of the Facility workscope RL milestone B10-00-001 } \\
\text { / } 5 / 31 / 00 \\
\text { Support completion of workphase 00-3 "Health of the Facilty" workscope RL milestone B10-00-002 } \\
/ 9 / 29 / 00\end{array}$} \\
\hline \multicolumn{3}{|l|}{ Cost Tarret (Thousands of dollars) } \\
\hline \multicolumn{3}{|l|}{$\$ 826$} \\
\hline Propram Manager & \multicolumn{2}{|c|}{ Control Account Manager } \\
\hline R K Hulvey & \multicolumn{2}{|l|}{ D L Polzin } \\
\hline
\end{tabular}




\section{Control Account Dictionary Advanced Reactors Transition Fast Flux Test Facility WBS 2010101210101}

\begin{tabular}{|c|c|c|c|c|c|}
\hline Tite & & & Date & PBS Number & Dictionary Rev \\
\hline RSM Engineering $M$ & imt Support & & 9/29/98 & RL-MS01 & 0 \\
\hline WBS Number & CAP Number & CACN & Baseline CR No & Organization & dedo: B \& R No \\
\hline 21112111164 & $1 \mathrm{~B} 1022$ & 101581 & & 18200 & AF79 \\
\hline
\end{tabular}

Provide program management of the FFTF Reactor Systems Mechanical Engıneering (RSME) group Conduct general activities including staff meetıngs safety meetıngs monthly reports etc

Complete RSME staff general and facility specific traınıng including HGET PIC Radiation Worker etc

Provide Cognizant Engineer / Design Authority function for more than fifty assigned systems and components in the FFTF, FMEF MASF and Landlord buildings Support the achievement of the "health of the facility" maintenance milestones Provide support to FFIF preventative maintenance (PM) activities including review and revision of PM categones frequencies and procedures and evaluation of data obtained from PM activities Provide support to FFTF corrective maintenance activities, including preparation of corrective maintenance and modification work packages and ordering of required materials As required supervise field work (i e Person in Charge activities)

Prepare review and approve FFTF operatung procedures related to assigned systems Perform configuration management activities including the maintenance of drawings in accordance with site requirements Prepare review and approve engineenng standands and procedures including maintenance of FFTF Engineering Instructions and participation on the FDH Engineering Leadership Team

Perform engineering studies related to plant restart $e \mathrm{~g}$, sodium and gas sampling processes and liquid effluent treatment options

Deliverables/Milestones (ttem/Date)

Support completion of workphase 00-1 "Health of the Facilty" workscope RL milestone B10-00-000 $/ 1 / 31 / 00$

Support completion of workphase 00-2 Health of the Facility workscope RL milestone B10-00-001 / 5/31/00

Support completion of workphase 00-3 "Health of the Facility workscope RL milestone B10-00-002 1 9/29/00

Cost Tarret (Thousands of dollars)

$\$ 912$

\begin{tabular}{l|l} 
Program Manager & Control Account Managar \\
\hline
\end{tabular}

R K Hulvey

T M Burke 


\section{Control Account Dictionary}

Advanced Reactors Transition

Fast Flux Test Facility

WBS 2010101210101

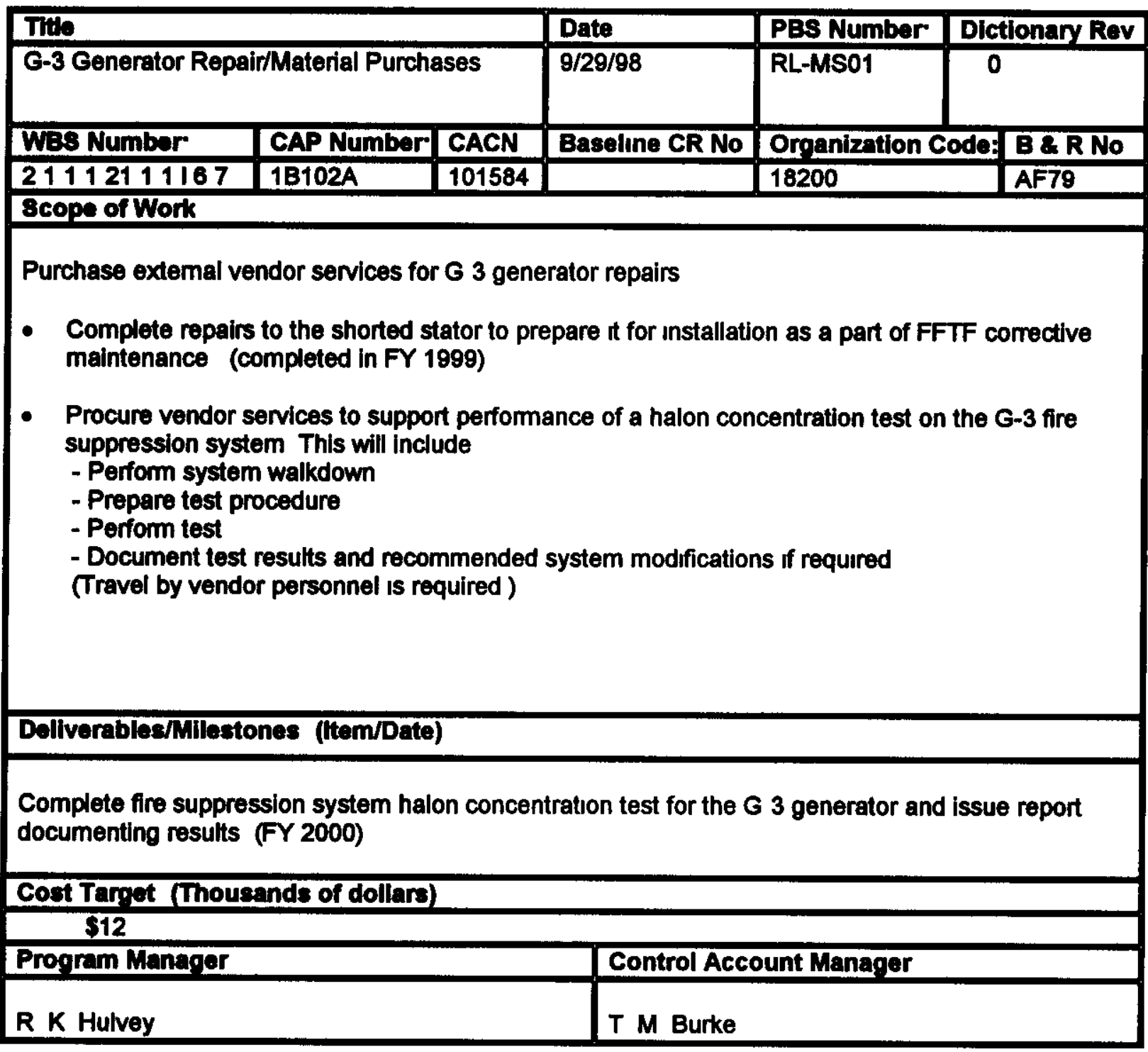




\section{Control Account Dictionary \\ Advanced Reactors Transition \\ Fast Flux Test Facility \\ WBS 2010101210101}

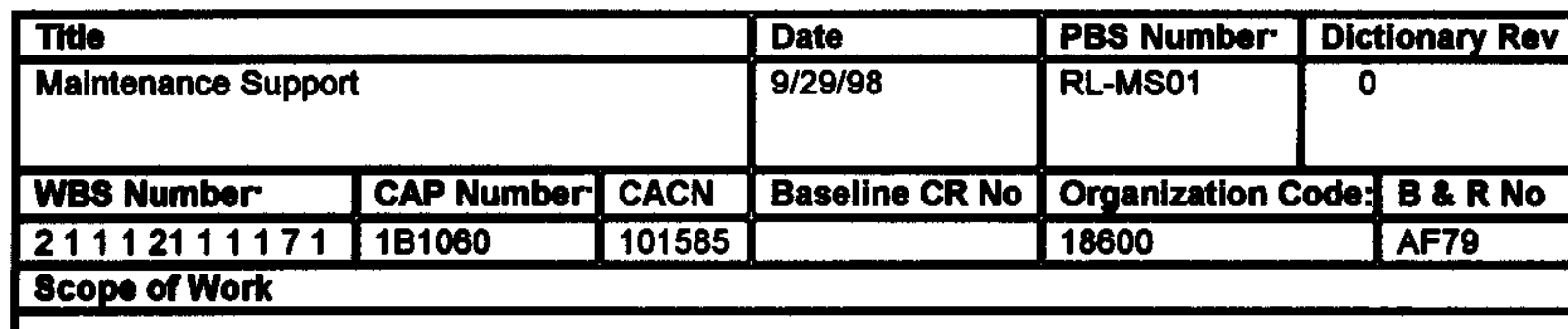

Provide program management of the FFTF Maintenance organization Perform general activities including staff meetings safety meetıngs monthly reports etc

Provide a trained and capable maintenance staff to support the FFTF and associated facilities Complete Maintenance staff general and facility specific trainıng including HGET PIC Radiation Worker etc Complete individual Maintenance staff mandatory technical/safety training $\mathbf{e g}$ medium risk and high risk electrical safety training confined space entry training etc

Plan schedule, manage, and perform surveillance procedures preventive and corrective maintenance for the Fast Flux Test Facility Maintenance and Storage Facility FMEF, and 400 Area support facilities (landlord buildings) Operate the work control center Provide Maintenance Person In Charge (PIC), as necessary to coordinate and direct fieldwork Purchase materials required for preventive and corrective maintenance and for maintenance administration activities

Provide calibrated equipment tools and external services required for performance of maintenance work

Maintain the yard and grounds at FFTF Including landscape maintenance and snow removal

\section{Dellverables/Milestones (item/Date)}

Complete workphase 00-1 Health of the Facility" workscope RL milestone B10-00-000 / 1/31/00

Complete workphase 00-2 "Health of the Facility" workscope RL milestone B10-00-001 / 5/31/00

Complete workphase 00-3 "Health of the Facilty" workscope RL milestone B10-00-002 / 9/29/00

Cost Tarrot (Thousands of dollars)

$\$ 8,609$

Program Managor

Control Account Manager

R K Hulvey

G J Boehnke 


\section{Control Account Dictionary \\ Advanced Reactors Transition \\ Fast Flux Test Facility \\ WBS 2010101210101}

\begin{tabular}{|c|c|c|c|}
\hline \multirow{2}{*}{\multicolumn{2}{|c|}{$\begin{array}{l}\text { Thle } \\
\text { FMEF S\&M Support }\end{array}$}} & \multirow{3}{*}{$\begin{array}{l}\text { Date } \\
\text { 9/29/98 } \\
\text { Baseline CR No }\end{array}$} & \multirow{2}{*}{\begin{tabular}{|c|c} 
PBS Number & Dictlonany Rov \\
RL-MS01 & 0
\end{tabular}} \\
\hline & & & \\
\hline WBs Number & CAP Number CACN & & \begin{tabular}{l|l} 
Organization Code & B \& R No
\end{tabular} \\
\hline 21112111181 & $\begin{array}{ll}1 B 170 A & 101586 \\
\end{array}$ & & \begin{tabular}{r|r|}
18100 & AF79 \\
\end{tabular} \\
\hline \multicolumn{4}{|l|}{ Scope of Work } \\
\hline \multicolumn{4}{|c|}{$\begin{array}{l}\text { Maintain the Fuels and Materials Examination Facility (FMEF) in a safe secure environmentally } \\
\text { compllant shutdown condition Except for leased storage and workshop areas the building is } \\
\text { unoccupied } \\
\text { Maintain the fire detection and suppression systems heatıng system (to prevent freezing of water } \\
\text { systems), and building integrity so as to protect the DOE investment in this facility Perform } \\
\text { necessary preventive and corrective maintenance activities } \\
\text { Receive offsetting income from programs which utilize space for storage or workshop purposes }\end{array}$} \\
\hline \multicolumn{4}{|c|}{ Deliverables/Milestones (item/Date) } \\
\hline \multicolumn{4}{|c|}{ No discrete deliverables } \\
\hline \multicolumn{4}{|c|}{ Cost Tarret (Thousands of dollars) } \\
\hline \multicolumn{4}{|c|}{$\$ 271$} \\
\hline Proqram Manager & & Control Acce & ount Manager \\
\hline R K Hulvey & & S V Doebler & \\
\hline
\end{tabular}


HNF-SD-FF-SSP-050

Rev 8 Page 61

\section{Hanford Site Work Breakdown Structure Dictionary FFTF PROJECT \\ WBS 20101012101}

\begin{tabular}{|c|c|c|c|c|}
\hline \multicolumn{2}{|l|}{ Activity Thite } & Date & PBS Number" & Dictionary Rev \\
\hline \multicolumn{2}{|c|}{ Remove Materials from FFTF } & $8 / 31 / 98$ & MS01 & 0 \\
\hline WBs Number & Baseline CR No & \multicolumn{2}{|c|}{ Organization Code } & BgR Number \\
\hline 201010121010102 & & \multicolumn{2}{|c|}{18000} & AF79 \\
\hline \multicolumn{5}{|c|}{$\begin{array}{l}\text { Scope of Work } \\
\text { This WBS provides those activities necessary for the removal of nuclear materials (unirradiated and } \\
\text { inradiated fueled components) from the FFTF }\end{array}$} \\
\hline \multicolumn{5}{|c|}{$\begin{array}{l}\text { Offload all unusable fueled components from within FFTF and place them in interim storage Offload } \\
\text { unusable nonfueled components from within FFTF and ship them for disposal Activities in these } \\
\text { areas include Oversee the procurement and testing of Interim Storage Casks (ISCs) and Core } \\
\text { Component Casks (CCCS) prepare and approve detalled refueling plans and Interim Examination } \\
\text { and Maintenance Cell (IEMC) and Examination and Decontaminated Services (EDS) work plans, } \\
\text { perform necessary criticality evaluations conduct operational readiness assessments operate and } \\
\text { maintain the refueling equipment provide engineering maintenance and operations support for } \\
\text { component handling, washing, packaging and shipping operations assemble FFTF fuel assembly } \\
\text { data packages preserve FFTF nuclear equipment performance data and documentation }\end{array}$} \\
\hline \multicolumn{5}{|c|}{$\begin{array}{l}\text { Cument Year Work } \\
\text { Efforts will continue to upgrade and restore equipment required for handling FFTF fuel in order to } \\
\text { support rellable operation Specific activities will include completion of upgrades to the Closed Loop } \\
\text { Ex-Vessel Machine (CLEM) and the IEM Cell Sodium Removal System controls Additionally design } \\
\text { development, fabrication, and installation of required upgrades to the Solid Waste Cask will continue } \\
\text { Each of these machines or Systems is necessary to process unirradiated and irradiated fuel for } \\
\text { removal from the FFTF }\end{array}$} \\
\hline \multicolumn{5}{|c|}{$\begin{array}{l}\text { Qut-year Planning } \\
\text { TBD Out-year activities will be detemined based on the assigned mission }\end{array}$} \\
\hline \multicolumn{5}{|c|}{$\begin{array}{l}\text { This WaS covers work necessary to support satisfying the followng technical baseline requirements } \\
\text { for the Hanford clean up mission } \\
\text { - South } 600 \text { Area special nuclear materials shall be moved to the Central Plateau } \\
\text { - } 400 \text { Area uranium shall be interim stored in the } 400 \text { Area } \\
\text { - Nuclear materlals shall be moved from the } 400 \text { Area to the Central Plateau } \\
\text { - } 400 \text { Area Nuclear materials shall be stabilized } \\
\text { - Complete commercial disposition and/or the acquisition of new facilities modification of existing } \\
\text { facllties and/or modification of planned facilities necessary for storage treatmentprocessing and } \\
\text { disposal/disposition of all Hanford Site UU [Due Date } 12 / 31 / 2000] \text { TPA Target Milestone MX-92- } \\
06 T \\
\text { This target date includes all UU located in } 300 \text { Area fuel supply facilities (Uranium dioxide powder } \\
\text { and pellets stored in cans pins assemblies and drums) Uranium trioxide (UO3) powder stored in T- } \\
\text { hoppers adjacent to the U-Plant depleted UO3 stored in } 55 \text { gallon drums in the } 200 \text { West Area and } \\
\text { the } 4713 \text { Building }\end{array}$} \\
\hline \multicolumn{5}{|c|}{$\begin{array}{l}\text { Key documents used for allocating Site requirements to this WBS include } \\
\text { Name } \\
\text { Thtle } \\
\text { DOE/EIS-0222D Drat Hanford Remedial Action Environmental Impact St }\end{array}$} \\
\hline
\end{tabular}




\section{Control Account Dictionary \\ Advanced Reactors Transition \\ Fast Flux Test Facility \\ WBS 2010101210101}

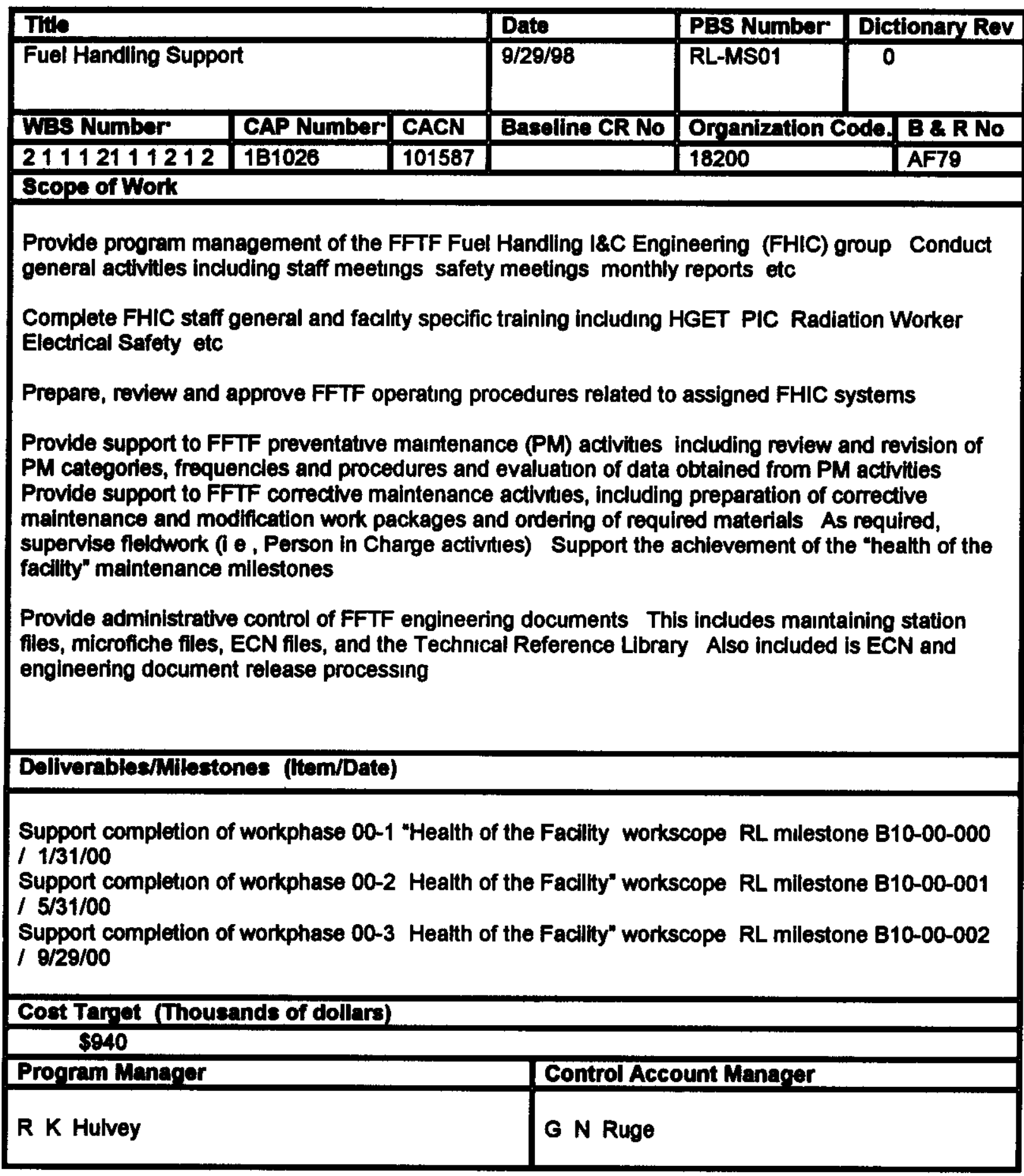




\section{Control Account Dictionary \\ Advanced Reactors Transition \\ Fast Flux Test Facility \\ WBS 2010101210101}

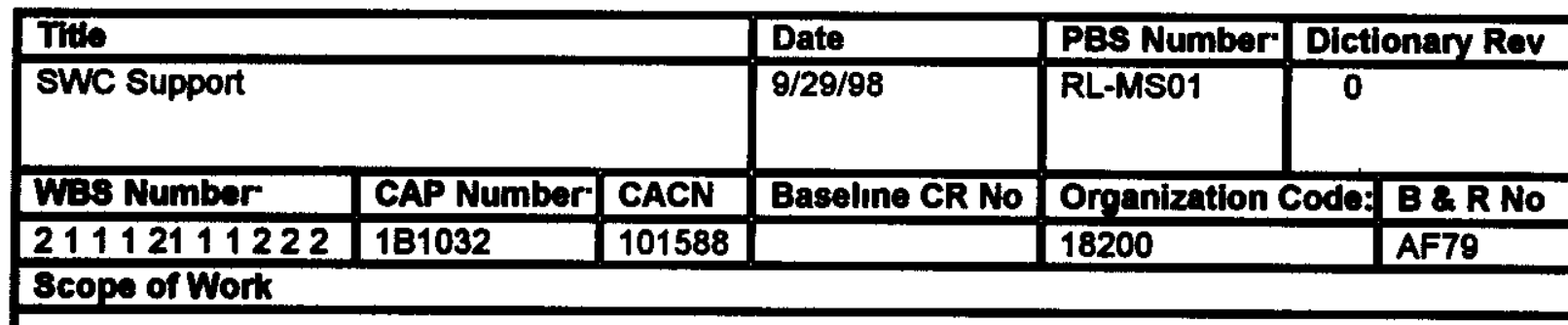

Complete the redesign and repair of the Solid Waste Cask to restore it to an acceptable condition for handling highly radioactlve waste containers and spent nuclear fuel in core component containers

In FY 2000, perform detalled design activities for the Solid Waste Cask (SWC) The cask requires a major upgrade to the hoist, grapple closure valve and its associated electrical control system to allow it to safely handle spent fuel containers and to increase its reliability

Conceptual design activities were completed in FY 1999 and Detailed Design is planned for completion by the end of FY 2000 Procurement fabrication installation and testing activities to support this upgrade will occur in FY 2001 \& FY 2002

This scope includes the engineering and drafting support to perform the design activity and the additional support to perform an independent design review and approval at the completion of detalled design The design effort review and approval are all part of the FY 2000 scope

\section{Deliverables/Milestones (item/Date)}

\section{RL Milestone B19-00-400 Due Date September 252000}

Complete the definitive design for repairs and upgrades to the Solid Waste Cask (SWC) to meet the design requirements for handling spent nuclear fuel This will fully define the scope to restore the grapple and hoist system, which failed as well as to assure an adequate confinement boundary An independent design review will be performed and the final design review report will be issued with a copy provided to RL

\section{Cost Tarpet (Thousands of dollars)}

3978

\begin{tabular}{|l|l}
\hline Program Manager & Control Account Manager \\
\hline
\end{tabular}

R K Hulvey

S W Hiller 


\section{Control Account Dictıonary Advanced Reactors Transition \\ Fast Flux Test Facility WBS 2010101210101}

\begin{tabular}{|c|c|c|}
\hline Thte & Date & Dictionary Rev \\
\hline CLEM Upgrade Support & 9/29/98 & RL-MS01 \\
\hline CAP Number CACN & Baseline CR No & Organization Code. B \& R No \\
\hline \begin{tabular}{|l|l|l|}
21112111241 & $1 B 1027$ & 101590 \\
\end{tabular} & & \begin{tabular}{l|l}
18200 & AF79 \\
\end{tabular} \\
\hline \multicolumn{3}{|l|}{ 8cope of Work } \\
\hline \multicolumn{3}{|c|}{$\begin{array}{l}\text { The computerized controls for the Closed Loop Ex-Vessel Machine (CLEM) are aged and require } \\
\text { replacement to ensure reliable maintainable operation This upgrade will replace the computers } \\
\text { monitors, } 1 / O \text {, and related equipment required to operate the machine rellably }\end{array}$} \\
\hline \multicolumn{3}{|c|}{$\begin{array}{l}\text { During FY } 1999 \text { this task proceeded such that the following tasks were completed resulting in RL } \\
\text { Milestone B19-99-403 being completed } 16 \text { days ahead of schedule } \\
\text { - Definitive design } \\
\text { - Sofware development } \\
\text { - Hardware design review } \\
\text { - Procurement fabrication and field installation of all required hardware }\end{array}$} \\
\hline \multicolumn{3}{|c|}{$\begin{array}{l}\text { During FY } 2000 \text { the following activities will be performed such that CLEM can be retumed to service } \\
\text { early in FY } 2001 \\
\text { - Calibration Grooming \& Alignment testing } \\
\text { - Sottware Design Review } \\
\text { - Acceptance Testing Phase I eg interlock checks and handlıng cold components } \\
\text { - Test Results and Review Team } \\
\text { - Acceptance Testing Phase II, eg handling irradiated fueled components }\end{array}$} \\
\hline \multicolumn{3}{|l|}{ Deliverables/Milestones (item/Date) } \\
\hline \multicolumn{3}{|l|}{$\begin{array}{l}\text { Complete CLEM Software Design Review } \\
\text { Level } 0 \text { Milestone complete by } 2 / 11 / 00\end{array}$} \\
\hline \multicolumn{3}{|c|}{$\begin{array}{l}\text { Complete Phase I Acceptance Testing of the CLEM control system upgrade } \\
\text { Level O Milestone complete by } 6 / 27 / 00\end{array}$} \\
\hline \multicolumn{3}{|c|}{$\begin{array}{l}\text { Complete Phase II Acceptance Testing of the CLEM control system upgrade } \\
\text { RL. Milestone B19-00-403/ } 9-14-00\end{array}$} \\
\hline \multicolumn{3}{|c|}{ Cost Target (Thousands of dollars) } \\
\hline \multicolumn{3}{|l|}{$\$ 400$} \\
\hline Progrem Manarer & \multicolumn{2}{|c|}{ Control Account Manager } \\
\hline R K Hulvey & \multicolumn{2}{|l|}{ G N Ruge } \\
\hline
\end{tabular}




\section{Control Account Dictionary \\ Advanced Reactors Transition}

Fast Flux Test Facility

WBS 2010101210101

\begin{tabular}{|c|c|c|c|c|c|}
\hline \multicolumn{3}{|c|}{ Tithe } & Date & PBS Number & Dictionary Rev \\
\hline \multicolumn{3}{|c|}{ IEM Cell \& Refueling Mech Eng Support } & $9 / 29 / 98$ & RL-MS01 & 0 \\
\hline WBS Numbar & CAP Number & CACN & Baselıne CR No & \multicolumn{2}{|c|}{ Orranization Code B \& R No } \\
\hline 21112111251 & $1 \mathrm{B1028}$ & 101591 & & & AF79 \\
\hline \multicolumn{6}{|c|}{ Scope of Work } \\
\hline \multicolumn{6}{|c|}{$\begin{array}{l}\text { The FFTF IEM Cell \& Refueling Mechanical Engineering (IRME) organization provides Design } \\
\text { Authority/Cognizant Engineering coverage for more than } 30 \text { systems related to reactor refueling and } \\
\text { spent fuel handling and storage Specific system assignments are provided in the Cognizant } \\
\text { Engineer/Design Authority listings The pnmary objective of this WBS element is to maintain those } \\
\text { fuel handllng equipment and systems to support the completion of "health of facility" maintenance } \\
\text { milestones }\end{array}$} \\
\hline \multicolumn{6}{|c|}{$\begin{array}{l}\text { In addition the following activities are provided by this element } \\
\text { - Program management of the IRME group } \\
\text { - Secretarial services for the IRME and RSME engineering groups (2 managers and } 18 \\
\text { engineering staff members) Secretarial duties involve preparation and issuance of } \\
\text { correspondence and reports routing and tracking work packages and procedures taking } \\
\text { messages, scheduling training prepanng monthly reports misc office equipment } \\
\text { procurements, and other administrative requirements } \\
\text { - General drafting support of IRME configuratıon management activities including maintenance } \\
\text { of drawings, incorporating ECNs etc } \\
\text { - Preparation of engineering studies related to restart activities (e g isotope target irradiation } \\
\text { hardware conceptual design inflatable seal replacement evaluation IT bellows replacement } \\
\text { study) as resources allow } \\
\text { Preparation review and approval of FFTF operatıng and maintenance procedures related to } \\
\text { assigned IRME systems } \\
\text { Supervision (PIC) of fieldwork related to systems/equipment IRME is responsible for }\end{array}$} \\
\hline
\end{tabular}

Maintenance activities on fuel handling systems and equipment are based on retaining the potential for a reactor restart while assuring minımal impact to cntical path should a shutdown or restart decision be recelved

Green fuel inventory and IDS siphon breaker testing will be performed in FY 2000

T-3 shipping cask license revision for metal fuel will be supported in FY 2000 per DOE request

ISC and DSWC SARP updates/renewals will be performed as required

Deliverables/Millestones (item/Date)

Support completion of workphase 00-1 Health of the Facility" workscope RL milestone B10-00-000

1 1/31/00

Support completion of workphase 00-2 Health of the Facility workscope RL milestone B10-00-001

$15 / 31 / 00$

Support completion of workphase 00-3 "Health of the Facility" workscope, RL milestone B10-00-002 $18 / 29 / 00$

Cost Tarret (Thousands of dollars)

$\$ 1,038$

\begin{tabular}{l|l} 
Propram Manager & Control Account Manager
\end{tabular}

R K Hulvey

s w Hiller 


\section{Control Account Dictionary \\ Advanced Reactors Transition \\ Fast Flux Test Facility \\ WBS 2010101210101}

\begin{tabular}{|c|c|c|}
\hline Tithe & Date & PBS Number Dictionary Rev \\
\hline SRS C1167 Support & $9 / 29 / 98$ & \begin{tabular}{l|l} 
RL-MS01 & 0
\end{tabular} \\
\hline CAP Number CACN & Baseline CR No & Organization Code B \& R No \\
\hline 21112111261 & & 18200 \\
\hline \multicolumn{3}{|l|}{ Scope of Work } \\
\hline \multicolumn{3}{|c|}{$\begin{array}{l}\text { This overall task will upgrade the Interim Examination and Maintenance (IEM) Cell Sodium Removal } \\
\text { System (SRS) control system panel C-1167 The upgrades will enhance the man-machine interface } \\
\text { the system reliability and maintainability, and the safety of performing mantenance }\end{array}$} \\
\hline \multicolumn{3}{|c|}{$\begin{array}{l}\text { During FY } 1999 \text { this task proceeded such that the following activities were completed } \\
\text { - Definitive hardware design } \\
\text { - Software development } \\
\text { - Design revlew for hardware and software } \\
\text { - Procurement of new hardware, except for computer }\end{array}$} \\
\hline \multicolumn{3}{|c|}{$\begin{array}{l}\text { During FY } 2000 \text { the following activities will be performed } \\
\text { - Software Testing } \\
\text { - Construction, i e, install new control system into existing control console C-1167 } \\
\text { - Prepare Operating Procedures that reflect operation of the upgraded SRS control system } \\
\text { - Perform training on the new SRS control system } \\
\text { - Procure process control computer }\end{array}$} \\
\hline \multicolumn{3}{|c|}{$\begin{array}{l}\text { Complete acceptance testing and return the Sodium Removal System to service (Projected for FY } \\
\text { 2001) }\end{array}$} \\
\hline \multicolumn{3}{|l|}{ Dellverablea/Milestones (Item/Date) } \\
\hline \multirow{2}{*}{\multicolumn{3}{|c|}{$\begin{array}{l}\text { During FY00 construction activities on C-1167 will be performed such that SRS can be returned to } \\
\text { service in FY } 2001 \\
\text { Complete construction/ Installation of new control system for SRS RL Milestone B19-00-402/9-22- } \\
00\end{array}$}} \\
\hline & & \\
\hline \multicolumn{3}{|c|}{ Cost Tarret (Thousands of dollars) } \\
\hline \multicolumn{3}{|l|}{$\$ 356$} \\
\hline Proqram Manager & \multicolumn{2}{|c|}{ Control Account Manager } \\
\hline R K Hulvey & \multicolumn{2}{|l|}{ G N Ruge } \\
\hline
\end{tabular}


TABLE 2-1 RESPONSIBILITY ASSIGNMENT MATRIX

\begin{tabular}{|c|c|c|c|c|}
\hline \multicolumn{5}{|c|}{ ADVANCED REACTORS TRANSITION } \\
\hline WBS No & CaCN & Title & Manager & $\begin{array}{c}\text { FY } 2000 \\
\text { Budget } \\
\text { (\$K) }\end{array}$ \\
\hline 1121 & \multicolumn{2}{|c|}{ ADVANCED REACTORS TRANSITION } & & \\
\hline 112.11 & \multicolumn{2}{|c|}{ NE Legacy Facilities } & & \\
\hline 112111 & \multicolumn{2}{|c|}{ Maintain Safe \& Compliant NE Legacy Facilities } & & \\
\hline 1121111 & 101541 & INE Leqacies Occupancy & W F Brehm & 413 \\
\hline 112.112 & \multicolumn{2}{|c|}{ Transition NE Legacy Facilities } & & \\
\hline 1121121 & 101542 & Temove and Ship 337 Controls \& Piping & WF Brehm & $\overline{0}$ \\
\hline 112112.2 & 101543 & Cloan 221 T Tanks & W F Brehm & 86 \\
\hline 11211.23 & 101544 & Complete Options for Non-Rad Sodium & W F Brehm & 0 \\
\hline 112.11 .24 & 101545 & Ciean $3718-M$ Storage Tank & W F Brehm & 0 \\
\hline 1121125 & 101546 & NE Legacy Support & W F Brohm & $\underline{0}$ \\
\hline 112.1128 & 110000 & 3378 Crane Repair & WF Brehm & 0 \\
\hline 1121.2 & \multicolumn{2}{|c|}{309 Facility } & & \\
\hline 112.121 & \multicolumn{2}{|c|}{ Maintain Safe \& Compliant 309 Bullding } & & \\
\hline 1121211 & 101547 & 309 Bullding Facllity & IL Metcalf & 709 \\
\hline 112122 & \multicolumn{2}{|c|}{ Transition 309 Facility } & & - \\
\hline 1121221 & 101548 & Tranekton TW Tank Farm & I L Metcalf & $\mathbf{0}$ \\
\hline 1121222 & 101549 & Stabllize PRTR Fuel Storage Basin & IL Motcalf & 0 \\
\hline 112.1223 & 101550 & Stabillze PRTR Reactor Cavity & IL Metcalf & $\overline{0}$ \\
\hline 1121224 & 101551 & Fuel Exam Cell & IL Motcalf & 0 \\
\hline 1121225 & 401552 & Stabllke PRTR Fuel Transfer Pit & I L Metcalf & 110 \\
\hline 1121226 & 101553 & Clean Out Balance PRTR Containment & IL Metalf & 0 \\
\hline 11212.27 & 101554 & Strablize 309 Bldg Stacks and Pit & I L Metcalf & $\overline{0}$ \\
\hline 1121228 & 101555 & Fecility Document Updates & IL Motcalf & 0 \\
\hline \multirow[t]{2}{*}{1121220} & 101556 & Transition 309 Building to Shutdown & IL Metcalf & 0 \\
\hline & & & & 1,318 \\
\hline
\end{tabular}


TABLE 2-1 RESPONSIBILITY ASSIGNMENT MATRIX (Cont'd) FAST FLUX TEST FACILITY

\begin{tabular}{|c|c|c|c|c|}
\hline WBS No & $\mathrm{CaCN}$ & Titile & Manager & Budget (SK) \\
\hline 21112111 & \multicolumn{3}{|c|}{ FAST FLUX TEST FACILITY } & \\
\hline 211121411 & \multicolumn{3}{|c|}{ Maintain Safe and Compliant Matenals in FFTF } & \\
\hline 2111211111 & \multicolumn{2}{|c|}{ Project Management } & & \\
\hline 21112111111 & 101557 & TPO Prooram Management & R K Hulvey & 3,198 \\
\hline 2111211111.2 & 101558 & Propect Control, Planning and Schoduling & WV Wherepoon & 789 \\
\hline 21112111113 & 101550 & Interretion Mansgement & D A Gantt & 507 \\
\hline 21112111114 & 101560 & SRID Adminlatration & WL Merehall & 258 \\
\hline 21112111115 & 101561 & Standby Project Support & J R Montano & 1,175 \\
\hline 211121111113 & 110245 & EIS Support & TM Burke & 320 \\
\hline 2.11121111114 & 111910 & Human/nduatrial Relatlons & J R Montano & 0 \\
\hline 2.111211112 & \multicolumn{2}{|c|}{ Material \& Property Secunty } & & \\
\hline 2.11121111 .21 & 101562 & IFFTF Matorial \& Property Security & D A Gantt & 4,436 \\
\hline 2111211113 & \multicolumn{2}{|c|}{ Inventory Control } & & \\
\hline 21112111131 & 101563 & Spare Parte Inventory Change & J R Montano & 149 \\
\hline 21112111132 & 101564 & Sparees Parts Wilhdrawal / Returns & J R Montano & 71 \\
\hline 2111211114 & \multicolumn{3}{|c|}{ FFTF Standby Operations } & \\
\hline 21112111141 & 101565 & TOperntions Mamt \& Support & S V Doobler & 6,055 \\
\hline 21112111143 & 101568 & Opee Analveis and Support & R L Mounce & 1,175 \\
\hline 2.1112111144 & 101567 & Opee Training Support & D J Rovira & 744 \\
\hline 21112111145 & 101568 & Open Pollicies and Procodures Support & D J Rovira & 79 \\
\hline 21112111147 & 112090 & Opes Coneumables & S V Doobler & 2,228 \\
\hline 21112111148 & 112100 & SOE Plant Operations & s V Doobler & 714 \\
\hline 21112111148 & 112101 & EDS Plant Operations & S V Doebler & 503 \\
\hline 2111211115 & \multicolumn{2}{|c|}{ Self Assessments \& Support } & & \\
\hline 21112111151 & 101500 & Redlologlcal Management Support & LA Notian & 989 \\
\hline 21112111152 & 101570 & Environmental Support & SE Klloy & 855 \\
\hline 21112111153 & 101571 & Sampling and Lab Support & SE Klloy & 78 \\
\hline 21112111154 & 101572 & Weeto Characterlzation Support & SE KWloy & 83 \\
\hline 2.1112111155 & 101573 & Pollukion Prevention Support & SE KNlloy & 10 \\
\hline 2.1112111156 & 101574 & LLW Dleoonal & SE KIlloy & 31 \\
\hline 2.1112111157 & 101575 & Weate Dieposal & SE KGHoy & 34 \\
\hline 21112111158 & 101576 & Sefoty Support & R O Zimmorman & 945 \\
\hline 21112111150 & 101577 & Quality Asourance & R O Zlmmerman & 502 \\
\hline 2111211116 & \multicolumn{3}{|c|}{ Maintain FFTF Sys Design } & \\
\hline 21112111181 & 101578 & TEnolncering Momt Support & s Guttenberg & 284 \\
\hline 2.1112111162 & 101579 & Aux Sye Electrical Eng Support & SH Crow & 1,260 \\
\hline 21112111163 & 101580 & Mechanical Eg \& Inservice Support & DL Poken & 820 \\
\hline 21112111164 & 101581 & RSM Engineering Mgmt Support & T M Burke & 012 \\
\hline 21112111167 & 101584 & O, 3 Generator RepairMaterial Purchases & T M Burke & 12 \\
\hline 2111211117 & \multicolumn{3}{|c|}{ FFTF Maintenance } & \\
\hline 21112111171 & 101585 & IMaintenance Support & G J Boehnke & 8,600 \\
\hline 2111211118 & \multicolumn{2}{|l|}{ FMEF } & & \\
\hline 21112111181 & 101586 & FMEF S\&M SUpport & S V Doebler & 271 \\
\hline 211121112 & \multicolumn{3}{|c|}{ Remove Materials from FFTF } & \\
\hline 2111211121 & \multirow{2}{*}{\multicolumn{2}{|c|}{$\begin{array}{l}\text { Fuel Handling } \\
101587 \text { Fuel Handling Support }\end{array}$}} & & \\
\hline 2.11121112 .12 & & & G N Ruge & 940 \\
\hline 2.11121112 .2 & \multicolumn{2}{|l|}{ swc } & & \\
\hline 2.11121112 .22 & 101588 & SwC Support & SW Hiller & 978 \\
\hline 211121112.4 & \multicolumn{2}{|c|}{ CLEM Uparade } & & \\
\hline 2.11121112 .41 & 101500 & CLEM Uporade Support & GN Ruge & 400 \\
\hline 2.141211125 & \multicolumn{2}{|c|}{ IEM Cell \& Refueling Admin } & & \\
\hline 21112111251 & 101591 & IEM Coll \& Rofueling Mech Eng Support & S W Hiller & 1,038 \\
\hline 2111211126 & \multicolumn{2}{|c|}{ SRS C1167 } & & \\
\hline 21112111261 & 101592 & SRS C1167 Support & G N Ruge & 356 \\
\hline & & & & 41,812 \\
\hline
\end{tabular}




\section{Master Schedule}

The Project Baseline Schedule is maıntained in the Pnmavera Project Planner (P3) ${ }^{\text {nt }}$ computer program A printout of this schedule is provided in Appendix A Over the course of the project the P3 schedule will be maintained under baselıne change control in accordance with HNF-PRO-533, Change Control

Summarization of this master schedule is provided in the Project Master Baseline Schedule, which appears in the Fiscal Year 2000 Multt-Year Work Plan Advanced Reactors Transition Program The MYWP can be accessed on the HLAN through Hanford Data Integrator (HANDI) A simplified pictorial representation is presented in Section 1 Executive Summary of this document

\section{Milestones}

Milestones have been established for completion of significant activities in the project schedule Dependent upon the significance of the activity these are assigned as Field Office (FO) RL or contractor $(O)$ level milestones The active milestones are listed in Table 31 in addition a number of milestones related to the Hanford Federal Facility Agreement and Consent Order (Tri-Party Agreement) are assigned to the project but are not being worked due to the DOE direction to maintain the FFTF in standby These milestones are listed in Table 32

Tri-Party Agreement change request M-81 98-01 was approved August 241999 placing the M-81 series of TPA milestones "in abeyance " and changıng the due date for M-20-29A to "TBD " Change M-92-98-01 was approved October 21999 placing the milestones M-92-09 and M-82-10 "in abeyance " These changes will be reflected in the project baselıne by BCR in the near future

\footnotetext{
P3 and Primavera Project Planner are trade names of Primavera Systems Inc
} 
TABLE 31 ACTIVE MILESTONES

\begin{tabular}{|c|c|c|c|c|}
\hline $\begin{array}{l}\text { Millestone } \\
\text { Number }\end{array}$ & $\begin{array}{c}\text { CAM / } \\
\text { Resp. Person }\end{array}$ & Iype & Milestone Description & $\begin{array}{l}\text { Scheduled } \\
\text { Date }\end{array}$ \\
\hline $810-00-004$ & Doebler & 0 & Identified FWS Qualifying Observations Complete & $10 / 14 / 99$ \\
\hline B10-00-005 & Doebler & 0 & Complete 10 Operational Drills & $10 / 31 / 99$ \\
\hline$\overline{B 10-00-006}$ & Doebler & 0 & Complete 10 Operatıonal Drills & $11 / 30 / 99$ \\
\hline B10-00-007 & Killoy & 0 & Quarterly DMR Submittal to Ecology & $11 / 30 / 99$ \\
\hline$B 10-00-003$ & Hanville & $\overline{\mathbf{R L}}$ & Venfy Contingency Plan for Y2K & $12 / 15 / 99$ \\
\hline B10-00-008 & Doebler & 0 & Complete 10 Operatıonal Drills & $12 / 30 / 99$ \\
\hline B10-00-009 & Doebler & 0 & Complete Reference Use Procedure Validation & $12 / 31 / 99$ \\
\hline B10-00-010 & Doebler & 0 & Complete 10 Operational Drills & $01 / 31 / 00$ \\
\hline$B 10-00-000$ & Boehnke & $\mathbf{R L}$ & Health of Facility Workphase $00-1$ & $01 / 31 / 00$ \\
\hline B10-00-011 & Ruge & $\mathbf{0}$ & Complete CLEM Software Design Review & $02 / 11 / 00$ \\
\hline B10-00-013 & Killoy & 0 & Quarterly DMR Submittal to Ecology & $02 / 28 / 00$ \\
\hline$B 10-00-012$ & Doebler & 0 & Complete 10 Operational Dnils & $02 / 28 / 00$ \\
\hline B10-00-015 & Polzın & 0 & Issue Annual SISI Report & $03 / 30 / 00$ \\
\hline$B 10-00-016$ & Griffin & 0 & Declaratıon of Readiness for ISMS Verification & $03 / 30 / 00$ \\
\hline B10-00-014 & Doebler & $\mathbf{0}$ & Complete 10 Operatıonal Donlls & $03 / 31 / 00$ \\
\hline B10-00-017 & Doebler & 0 & Complete 10 Operatıonal Drills & $04 / 30 / 00$ \\
\hline B10-00-018 & Killoy & $\mathbf{0}$ & Quarterly DMR Submittal to Ecology & $05 / 30 / 00$ \\
\hline$B 10-00-019$ & Doebler & 0 & Complete 10 Operatıonal Drills & $05 / 31 / 00$ \\
\hline$\overline{B 10}-00-001$ & Boehnke & $\mathbf{R L}$ & Health of Facility Workphase $00-2$ & $05 / 31 / 00$ \\
\hline B10-00-020 & Ruge & $\mathbf{0}$ & Complete CLEM Phase I Acceptance Testing & $06 / 27 / 00$ \\
\hline$B 10-\overline{00-021}$ & Doebler & 0 & Complete 10 Operatıonal Drills & $06 / 30 / 00$ \\
\hline$\overline{B 10-00-022}$ & Hiller & 0 & $\begin{array}{l}\text { Transmit SWC Design Review Package to Review } \\
\text { Team }\end{array}$ & $07 / 20 / 00$ \\
\hline$B 10-\overline{00-023}$ & Doebler & 0 & Complete 10 Operatıonal Drills & $07 / 31 / 00$ \\
\hline$\overline{B 10-00-024}$ & Killoy & $\overline{0}$ & Quarterly DMR Submittal to Ecology & $08 / 30 / 00$ \\
\hline B10-00-025 & Doebler & 0 & Complete 10 Operational Drills & $08 / 31 / 00$ \\
\hline B19-00-403 & Ruge & $\overline{\mathbf{R L}}$ & Acceptance Testıng for CLEM Control System & $08 / 14 / 00$ \\
\hline$B 19-00-402$ & Ruge & $\overline{\mathbf{R L}}$ & Sodium Removal System Control System Construction & $09 / 22 / 00$ \\
\hline$B 19-00-400$ & Hiller & $\overline{R L}$ & Defintive Design for the Solid Waste Cask & $09 / 25 / 00$ \\
\hline B10-00-002 & Boehnke & $\overline{\mathbf{R L}}$ & Health of Facility Workphase 00-3 & $09 / 29 / 00$ \\
\hline B10-00-028 & Doebler & 0 & Complete 10 Operational Drills & $09 / 30 / 00$ \\
\hline
\end{tabular}




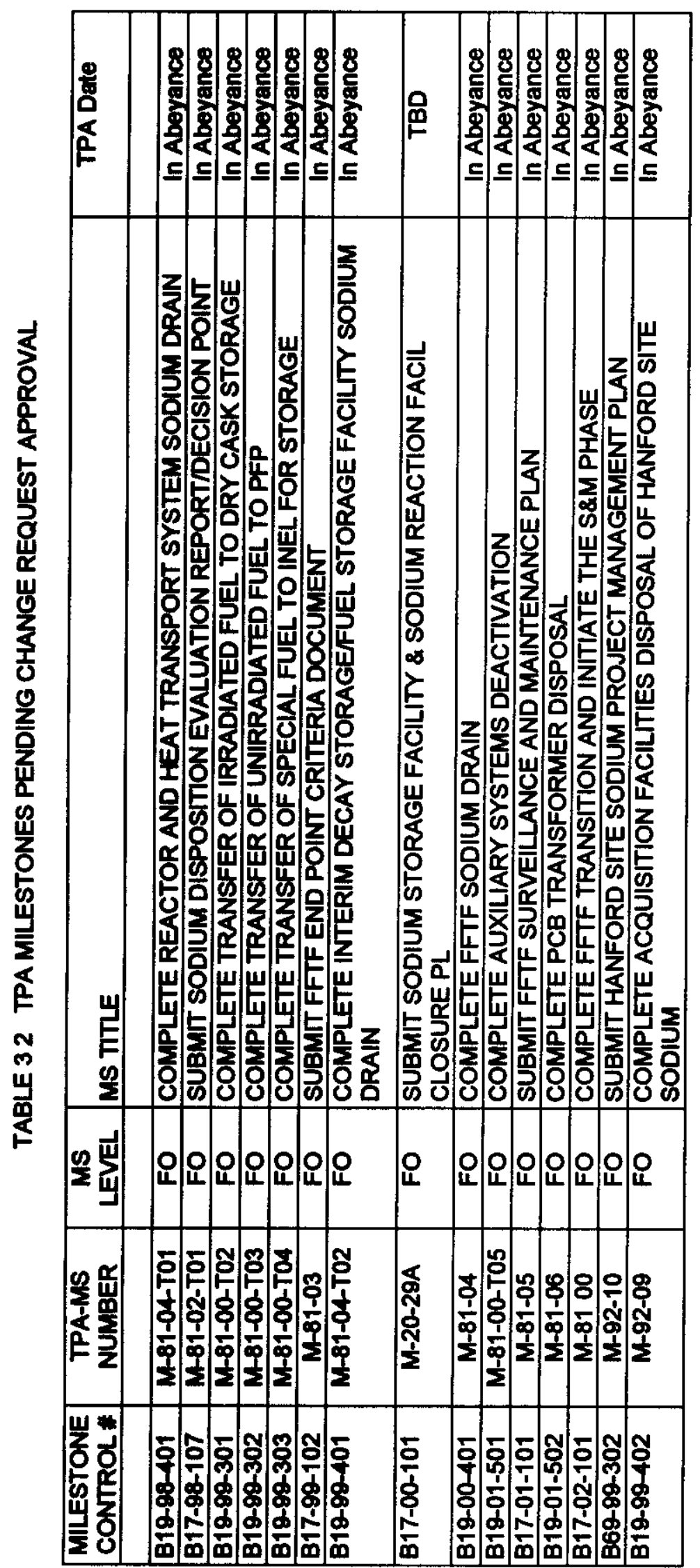


HNF-SD-FF-SSP-050

Rev 8, Page 72

This Page Intentionally Blank 


\section{0 costs}

The Advanced Reactors Transition and FFTF Standby cost estimates have been developed using Activity based Cost (ABC) estimating techniques Dependent upon the task, the estimating basis may be historical, based on best judgement definitive or a combination of these Planning rates and escalation applied to these estimates are consistent with those developed by the Fluor Daniel Hanford Company (FDH) Chief Financial Officer and approved by RL The FFTF Transition Project Office maintains the supportıng information in the 400 Area 4710 Building

\section{Cost Detail}

Cost reports are presented in Appendix B These reports document the budgeted resource usage, the fully burdened resource rate and the resource cost as well as cost subtotals for the various tasks Costs for FFTF WBS 21112111 ) are presented only for the current fiscal year, due to the lack of a defined mission Costs for NE Legacies and PRTR (WBS 112 1) are presented for the life cycle of these projects Costs shown in these reports for FY 2000 are in current year dollars using current rates for FY 2001 and beyond FY 2001 dollars and rates are used Any additional escalation must be accounted for manually

Additional costs paid directly by RL such as FFTF radıological and non-radiological laundry fees and NE Legacy steam expenses are not included in the Appendix B reports

\section{Cost Baseline}

421 Cost Baseline by Year

Table 41 shows the Advanced Reactors Transition cost baselıne by year The FFTF cost baseline has only been established for the current year refer to Table 42

\section{Current Year Cost Baseline}

Table 43 lists the FY 1999 cost baseline for each Cost account Change Number in the ART and FFTF projects The backup detail is provided in Appendix B

\section{Budget Authority}

Table 44 identifies the budget authonty planning basis Final budget authority will be identified in the RL financial plan

\section{Planned Staffing}

The ART planned staffing for NE Legacies and PRTR/309 Building activities is 80 FTE

The FFTF planned staffing is 254 direct staff for FY 2000 with an additional 13 FTE of supporting staff from outside of the FFTF organization The supporting staff FTE may or may not represent a discrete individual These supporting FTE include Protection Technology Hanford exempt, nonexempt and crafts, Dyncorp crafts and custodial support personnel and WMH corrective action management personnel Out-year staffing will be a function of the mission decision 


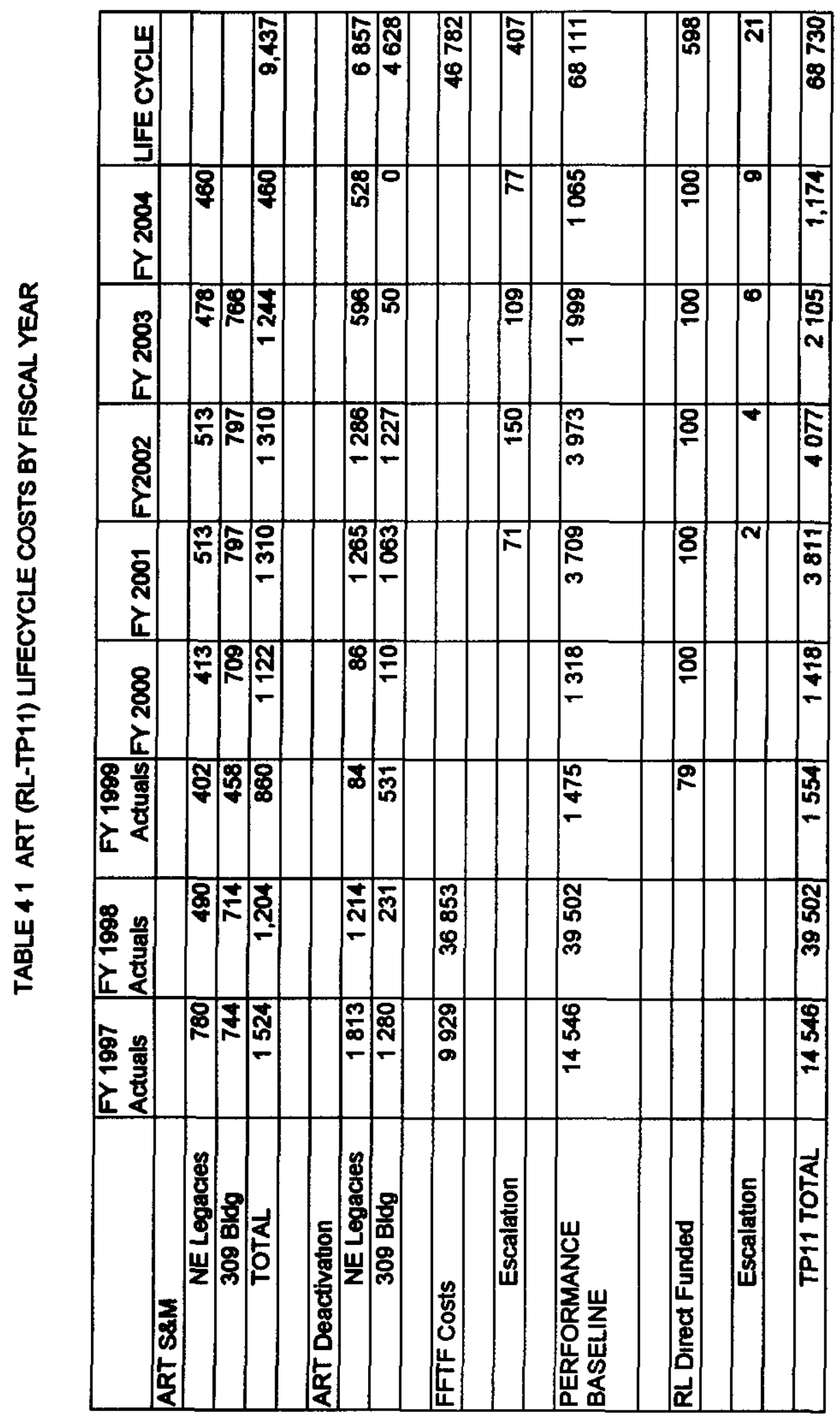


HNF-SD-FF-SSP-050

Rev 8 Page 75
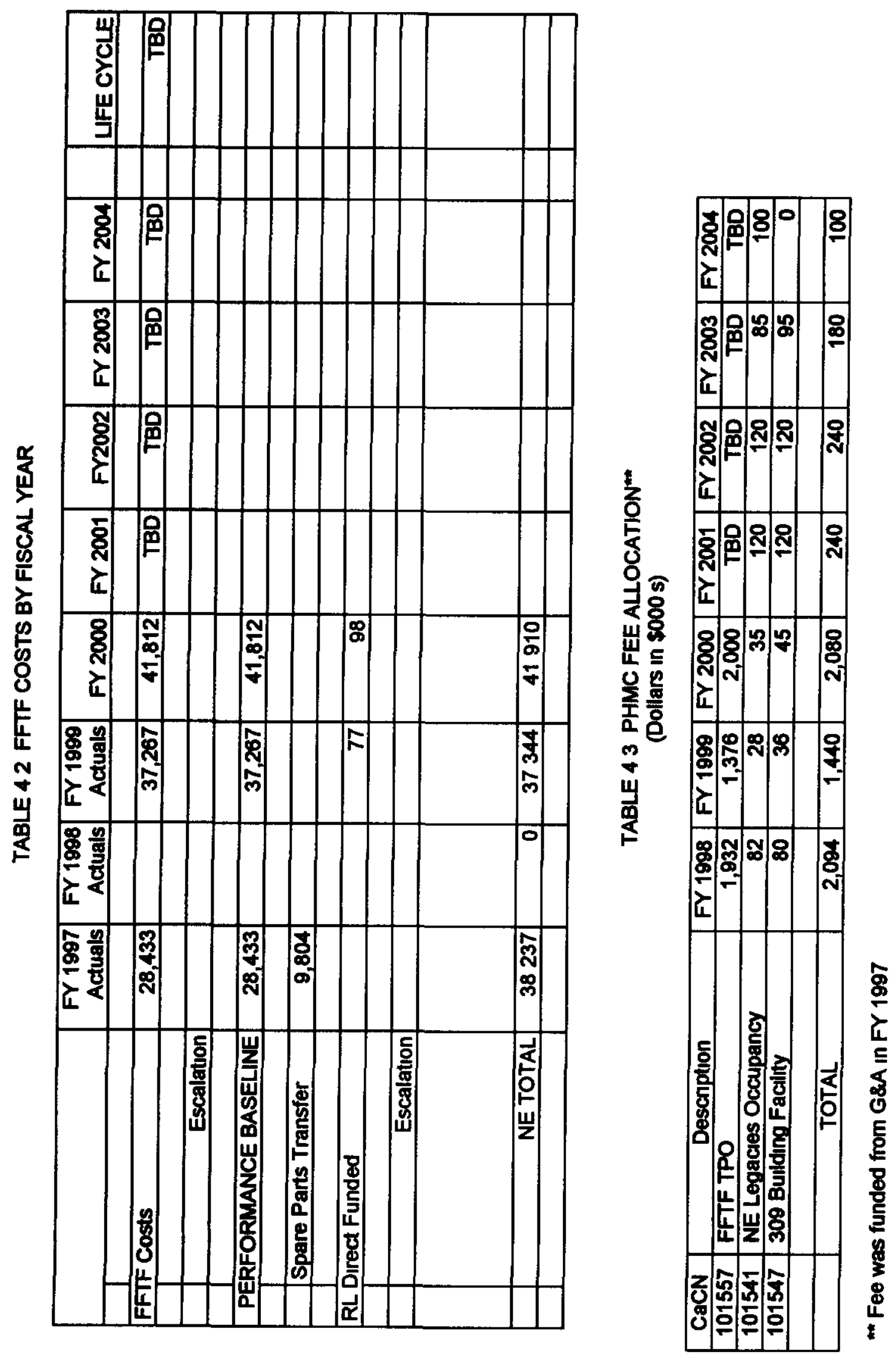
TABLE 44 FY 2000 COST BASELINE

ADVANCED REACTORS TRANSITION

\begin{tabular}{|c|c|c|c|c|}
\hline WBS No & CaCN & Title & Manager & $\begin{array}{c}\text { FY } 2000 \\
\text { Budget } \\
\text { (\$K) }\end{array}$ \\
\hline 1121 & \multicolumn{2}{|c|}{ ADVANCED REACTORS TRANSITION } & & \\
\hline 11211 & \multicolumn{2}{|c|}{ NE Legacy Facilities } & & \\
\hline 112111 & \multicolumn{2}{|c|}{ Maintain Safe \& Compliant NE Legacy Facilities } & & - \\
\hline 1121111 & 101541 & INE Lopacies Occupancy & WF Brohm & 413 \\
\hline 112112 & \multicolumn{2}{|c|}{ Transition NE Legacy Facilities } & & - \\
\hline $1121+21$ & 104542 & TRemove and Ship 337 Controls \& Piping & WF Brchm & $\overline{0}$ \\
\hline 112.1122 & 101543 & Cloan 221 T Tanks & W F Brohm & 86 \\
\hline 11211.23 & 101544 & Complete Options for Non-Rad Sodium & W F Brehm & 0 \\
\hline 11211.24 & 101545 & Clean $3718-M$ Storage Tank & WF Brehm & 0 \\
\hline 112.1125 & 101546 & NE Legacy Support & W F Brehm & 0 \\
\hline \multirow[t]{2}{*}{1121126} & 110000 & 3378 Crane Repair & W F Brchm & $\overline{0}$ \\
\hline & & & & \\
\hline 11212 & \multicolumn{2}{|c|}{309 Facility } & & \\
\hline 112121 & \multicolumn{2}{|c|}{ Maintain Safe \& Compliant 309 Building } & & - \\
\hline 1121211 & 101547 & 309 Building Facillty & I L Motcalf & 709 \\
\hline 112122 & \multicolumn{2}{|c|}{ Transition 309 Facility } & & - \\
\hline 1121221 & 101548 & Transiltion TW Tank Farm & IL Metealf & 0 \\
\hline 112.122 .2 & 101549 & Stabllize PRTR Fuel Storage Badin & I L Metcalf & 0 \\
\hline 112.1223 & 101550 & Stabilize PRTR Reactor Cavity & I L Metalli & 0 \\
\hline 1121224 & 101551 & Fuel Exam Cell & IL Metcalf & 0 \\
\hline 1121225 & 101552 & Stabillze PRTR Fuel Transfer Plt & IL Metealf & 110 \\
\hline 1121226 & 101553 & Cloan Out Balance PRTR Containment & I L Metcalf & 0 \\
\hline 11212.27 & 101554 & Stabilize 309 Bldg Stacks and Pif & TL Metealf & 0 \\
\hline & 101555 & Facilly Document Updates & I L Metcalf & $\overline{0}$ \\
\hline \multirow[t]{2}{*}{1121228} & 101558 & Transition 309 Bullding to Shutdown & I L Metcalf & 0 \\
\hline & & & & 1,318 \\
\hline
\end{tabular}


TABLE 44 FY 2000 COST BASELINE (Cont'd) FAST FLUX TEST FACILITY

\begin{tabular}{|c|c|c|c|c|}
\hline WBS No & $\mathrm{CaCN}$ & Title & Manager & Budoet (SK) \\
\hline 21112111 & \multicolumn{4}{|c|}{ FAST FLUX TEST FACILITY } \\
\hline 2.11121111 & \multicolumn{3}{|c|}{ Maintain Safe and Compliant Matenals in FFTF } & \\
\hline 2.111211111 & \multicolumn{2}{|c|}{ Project Management } & & \\
\hline 21112111111 & 101557 & TPO Prooram Management & R K Hulvoy & 3,180 \\
\hline 2.1112111112 & 101558 & Prolect Control, Planning and Scheduling & W V Witheripoon & 788 \\
\hline 21112111113 & 101550 & Interration Management & DA Gantt & 5 \\
\hline 21112111114 & 101560 & SRID Administration & W L. Merchall & 24 \\
\hline 21112111115 & 101581 & Standby Project Support & JR Montano & 1,1 \\
\hline 2.11121111113 & 110245 & EIS Support & s Guttonberg & 3 \\
\hline 2.11121111114 & 111910 & Human/industrial Relations & $J R$ Montano & \\
\hline 2111211112 & \multicolumn{2}{|c|}{ Material \& Property Secunty } & & \\
\hline 2.1112111121 & 101502 & TFFTF Material \& Property Securtty & D A Gantt & 4,430 \\
\hline 2.111211113 & \multicolumn{2}{|c|}{ Inventon Control } & & \\
\hline 2.1112111131 & 101563 & Spare Parte Inventory Change & JR Montano & 1 \\
\hline 21112111132 & 101564 & Speres Parts Withdrawal / Returns & J R Monteno & \\
\hline 2111211114 & \multicolumn{3}{|c|}{ FFTF Standby Operations } & \\
\hline 21112111141 & 101565 & Operations Mamt \& Support & S V Doobler & 8,0 \\
\hline 21112111143 & 101568 & Opees Analyeis and Support & R L Mounce & 1,17 \\
\hline 21112111144 & 101567 & Opes Training Support & D J Rovire & 74 \\
\hline 21112111145 & 101568 & Opes Pollicies and Procedures Support & DJRovira & \\
\hline 21112111147 & 112000 & Opes Coneumables & S V Doabler & 2,22 \\
\hline 21112111148 & 112100 & SOE Plant Operations & S V Doobler & 71 \\
\hline 2.1112111148 & 112104 & EDS Plant Operations & S V Doebler & 50 \\
\hline 2.111211115 & \multicolumn{2}{|c|}{ Self Assessments \& Support } & & \\
\hline 2.1112111151 & 101500 & Redlological Management Support & L A Nelean & 98 \\
\hline 21112111152 & 101570 & Envlronmental Support & S E KHoy & 85 \\
\hline 21112111153 & 101571 & Sampling and Lab Support & SE Killoy & \\
\hline 21112111154 & 101572 & Wecte Characterization Support & SE Killoy & 8 \\
\hline 21142111155 & 101573 & Pollution Prevention Support & SE Kalloy & \\
\hline 21112111156 & 101574 & LLW Disposal & SE Killoy & \\
\hline 21112111157 & 101575 & Wede Disposal & SE KIlloy & \\
\hline 21112111158 & 101578 & Safcty Support & RO Zimmerman & $\bar{g}$ \\
\hline 21112111159 & 101577 & Quell'y Acsurance & Ro Zimmerman & $\overline{5}$ \\
\hline 2111211416 & \multicolumn{3}{|c|}{ Maintain FFTF Sys Design } & \\
\hline 2.1112191161 & 101578 & Enoinoering Momt Support & S Guttonbarn & \\
\hline 2.1112111162 & 101579 & Aux Sye Electrical Eng Support & S H Crow & 1,2 \\
\hline 21112111183 & 101580 & Mechanical Eq \& Inservice Support & DL Polzin & 8 \\
\hline 21112111164 & 101581 & RSM Engineering Mqm Support & TM Burke & 91 \\
\hline 21112111187 & 101584 & G-3 Generator RepatriMaterial Purchasees & T M Burke & \\
\hline 2111211117 & \multicolumn{3}{|c|}{ FFTF Maintenance } & \\
\hline 21112111171 & 101585 & Maintenance Support & G J Boohnke & 8,606 \\
\hline 2111211118 & \multicolumn{2}{|l|}{ FMEF } & & \\
\hline 21112111181 & 101586 & FMEF S\&M Support & S V Daebler & 27 \\
\hline 211121112 & \multicolumn{3}{|c|}{ Remove Materials from FFTF } & \\
\hline 2111211121 & \multirow{2}{*}{\multicolumn{2}{|c|}{\begin{tabular}{l} 
Fuel Handling \\
101587 \\
\multicolumn{1}{|c|}{ Fuel Handling Support }
\end{tabular}}} & & \\
\hline 21112111212 & & & GNRuge & 9 \\
\hline 2111211122 & \multicolumn{2}{|l|}{ SWC } & & \\
\hline 21112111222 & 101588 & SWC Support & SW Hiller & 97 \\
\hline 2111211124 & \multicolumn{2}{|c|}{ CLEM Uparade } & & \\
\hline 24112111241 & $1015 \% 0$ & CLEM Uporade Support & GN Rupe & 40 \\
\hline 2911211125 & \multirow{2}{*}{\multicolumn{2}{|c|}{$\begin{array}{l}\text { I\& Refueling Admin } \\
\text { IIEM Coll \& Refueling Mech Eng Support }\end{array}$}} & & \\
\hline 21112111251 & & & SW Hilier & $1,03 x$ \\
\hline 2111211126 & \multirow{2}{*}{\multicolumn{2}{|c|}{ SRS C1167 }} & & \\
\hline 21112111261 & & & G N Rune & 356 \\
\hline & & & & \\
\hline
\end{tabular}


Rev 8 Page78

TABLE 45 FY 2000 BUDGET AUTHORITY

\begin{tabular}{|l|r|r|}
\hline Funding Type/Source & \multicolumn{1}{|c|}{ RL-TP11 } & \multicolumn{1}{|c|}{ FFTF } \\
\hline FY 2000 Appropriation (Expected) & $\$ 1,418$ & $\$ 40,000$ \\
\hline RL Hold Back for Direct Funded Support (Expected) & -100 & -98 \\
\hline New Budget Authority & $\$ 1,318$ & $\$ 39,902$ \\
\hline Project Carryover & 0 & $\$ 1,900$ \\
\hline & & $\$ 1,802$ \\
\hline TOTAL PLANNED B/A & $\$ 1,318$ & $\$ 40$ \\
\hline
\end{tabular}




\section{RESOURCE LOADED SCHEDULE BASIS}

The Resource Loaded Schedule (RLS) is the result of a multi-step process The steps involve developing project plans, a work breakdown structure detailed workscope and logic relationships and resource assionments The resulting information was input to the Primavera Project Planner (P3) ${ }^{1}$ computer program This software program is a site wide project management-scheduling standard

\section{Methodology and Historical Basis}

The Initial development of the FFTF Transition Project RLS is described in Reference 13 The RLS has been managed by formal change control since being interfaced with the Hanford Site Financial Data System at the beginning of FY 1995 The NE Legacies and 309 Building activities were added into the RLS as it matured and this workscope was added to the ART Program The RLS became the ART Program RLS in 1995

The RLS continues to be maintained as an activity based document Baseline estimates are periodically reviewed and revised as workscope is better defined and project experience adds to the historical basis Baseline adjustments are documented and entered into the P3 database in the normal course of project development

Cognizant plant personnel for assigned tasks develop estımates These estimates are reviewed and revised on a periodic basis and as new information is developed through changes in guldance or through experience

\section{Basic Data and Estimate Backup Sheets}

The development and maintenance of the RLS is directly supported by a large set of basic data and estimate backup sheets (referred to as backup files) These files document the assumptions resource needs and estimated costs of transition activities The current estimate basis is documented on "Cost Estimate Input Sheets which document the FY 2000 planning basis

Several other types of backup files are available to support this RLS One such group of files is the System Shutdown Assessment Plans for each FFTF system FFTF Engineering developed these plans as the baseline documents for initial input to the RLS and system and component shutdown technical planning The plans are issued as Supporting Documents and are maintained by formal change control These files can be accessed through the FFTF Engineering group

A more recent set of estimate inputs (FY 1997) were entered on Excel spreadsheet task/activity planning and estimating sheets, which provided data electronically into both Project/2, Series $X$ $(P / X)^{2}$ and the Interactive Estimating Software Tool (IEST) data base PIX has subsequently been converted to P3 These estimates were updated again as a part of the fiscal year planning process

The resource estimate and logic file provides a histoncal basis and an estimate basis This file is based upon the System Shutdown Assessment Plans The data was directly input into the PIX software database, from which the resource loaded schedules and cost estimates at the task package level were developed As more knowledge is gained on specific activities the level of detail applied to logic and resource needs can be enhanced These files can be obtained from the FFTF Planning and Scheduling Integratıon group

\footnotetext{
${ }_{1}^{1}$ P3 and Primavera Project Planner are trade names of Pnmavera Systems inc

2 Project/2, Series X (PIX) is a trade name of Project Software \& Development Inc
} 
Other backup files include historical data from the Job Control System-Automated Data Program (e g , corrective and preventive maintenance performance of compliance activities in the areas of operational surveillances, environmental and fire system compliance checks and instrument calibrations) detalled refueling plans IEM Cell work plans past Plan-of-the-Day scheduling meetings and special operational procedures These files can be obtained from the FFTF Planning and Scheduling Integratıon group and FFTF Maıntenance organization

The PRTR/309 Bullding estimates were initially performed by an outside contractor and documented in reference 4 The project management team based upon actual performance during deactivation, has refined these estimates

All changes to the P3 database affecting the program baseline are formally documented using a Baseline Change Request (BCR) form These BCR s which contain a description of the change and justification, also become part of the RLS backup files They can be obtained from the FFTF Planning and Scheduling Integration group

\section{Cost Estimate Reviews}

During the periodic updates of the cost estımate representatıves of the RL project office provide oversight and review Selected portions of the cost estimate have been reviewed as a part of the RL process to validate the budget request process in addition two more complete independent reviews have been conducted

Project Time \& Cost Inc (PT\&C) conducted an independent review of the cost estimate process and results during the time period September 1995 through March 1996 This review focused on the FFTF transition to shutdown costs for the FFTF and also reviewed cost estimates for NE Legacies and 309 Facillty deactivation Recommendations from this review were evaluated and incorporated into the baseline as appropriate

RL Mission Planing Division accompanied by representatives from DOE-HQ office of Nuclear Energy Science and Technology (NE) and Chief Financial Officer (CFO), conducted a review of the FFTF standby cost estimate in November 1999 The review team concluded that the management systems used to develop project budgets and control costs were adequate and the FY 2000 planning estimate was complete and well documented ${ }^{16}$ 


\section{BASELINE CHANGE CONTROL}

Changes to the ART Program cost schedule and technical baselines are managed and controlled in compliance with the RL Project Management System (Reference 14) and HNF-PRO-533 The project plans the RLS and the current ART Program MWWP define the ART baseline The RLS provides project cost and schedule information consistent with the project plans The ART Program NWWP is the authonzing document for implementation of the project plans and the RLS The plans, RLS and MYWP are supporting documents controlled by formal change control via engineering change notice

The following software systems track project baseline information at the site level

Hanford Site Technical Data Base (HSTD) tracks site integration level information from the "Technical Baseline "

P-3 provides the project cost and schedule baseline Baseline and performance information is transferred from this software to PERF performance module and from PERF to the Hanford Data Integration" (HANDI) module PERF and HANDI however are data collection and reporting tools the baseline is maintained in P3 


\section{REFERENCES}

1 HNF-SD-FF-SSP-056, Rev 1 "Fast Flux Test Facality Standby Plan," B\&W Hanford Company January 301998

2 WHC-SD-FF-MP-001 Rev 1, "Hanford Site Sodium Management Plan," Westinghouse Hanford Company September 261995

3 Deleted

4 WHC-SD-SP-SSP-001 Rev 1 "309 Building Transition Plan," Westınghouse Hanford Company, April 28, 1995

5 Hanford Data Integration (Handi) data base "Fiscal Year 2000 Multi-Year Work Plan Advanced Reactors Transition Program " 10/1/99 version

6 DOE Press Release R-97-002 "Energy Department s Hanford Reactor put on 'Hot Standby "' dated January 151997

7 Letter, S A Sieracki, RL to H J Hatch FDH "Contract No DE-AC06-98RL13200 Advanced Reactors Transition (ART) Program Direction " 97-TPD-003 dated January 18 1897

8 Letter L J Olguin FDH to W F Heer BWHC "Contract No DE-AC06-96RL13200 Advanced Reactors Transition (ART) Project Direction " 9751456A R1, dated March 4, 1997

9 Memorandum, D A Dreyfus Actıng Director Office of Nuclear Energy, to J D Wagoner, RL "Commence Fast Flux Test Facility Shutdown (FFTF) Activities " dated December 15 1993

10 Letter, J D Wagoner RL to T M Anderson WHC "Fast Flux Test Facility (FFTF) Shutdown " OTD OAF dated December 151993

11 WHC-SD-FF-SSP-004 Rev 3 "Fast Flux Test Facilty Stabilization Project Plan," B\&W Hanford Company November 151996

12 Deleted

13 WHC-SD-FF-SSP-050, Rev 1 Fast Flux Test Facility Transition Project Resource Loaded Schedule "Westinghouse Hanford Company October 311994

14 DOE 47001 Rev 2 "Project Management System " U S Department of Energy June 2 1992

15 Deleted

16 Letter, Keith A Klein, DOE-RL to Michael L Telson and William D Magwood DOE-HQ FFTF Standby Budget Evaluation Report letter number MPD EJR/00-MPD-005 dated December 16, 1999 
APPENDIX A

SCHEDULES

Project

Page

Advanced Reactors Transition

NE Legacy Facilties

87

309 Busldıng Facılity

88

Fast Flux Test Facility 
HNF SD-FF-SSP-050

Rev 8 Page 86

THIS CHANGE INTENTIONALLY BLANK 


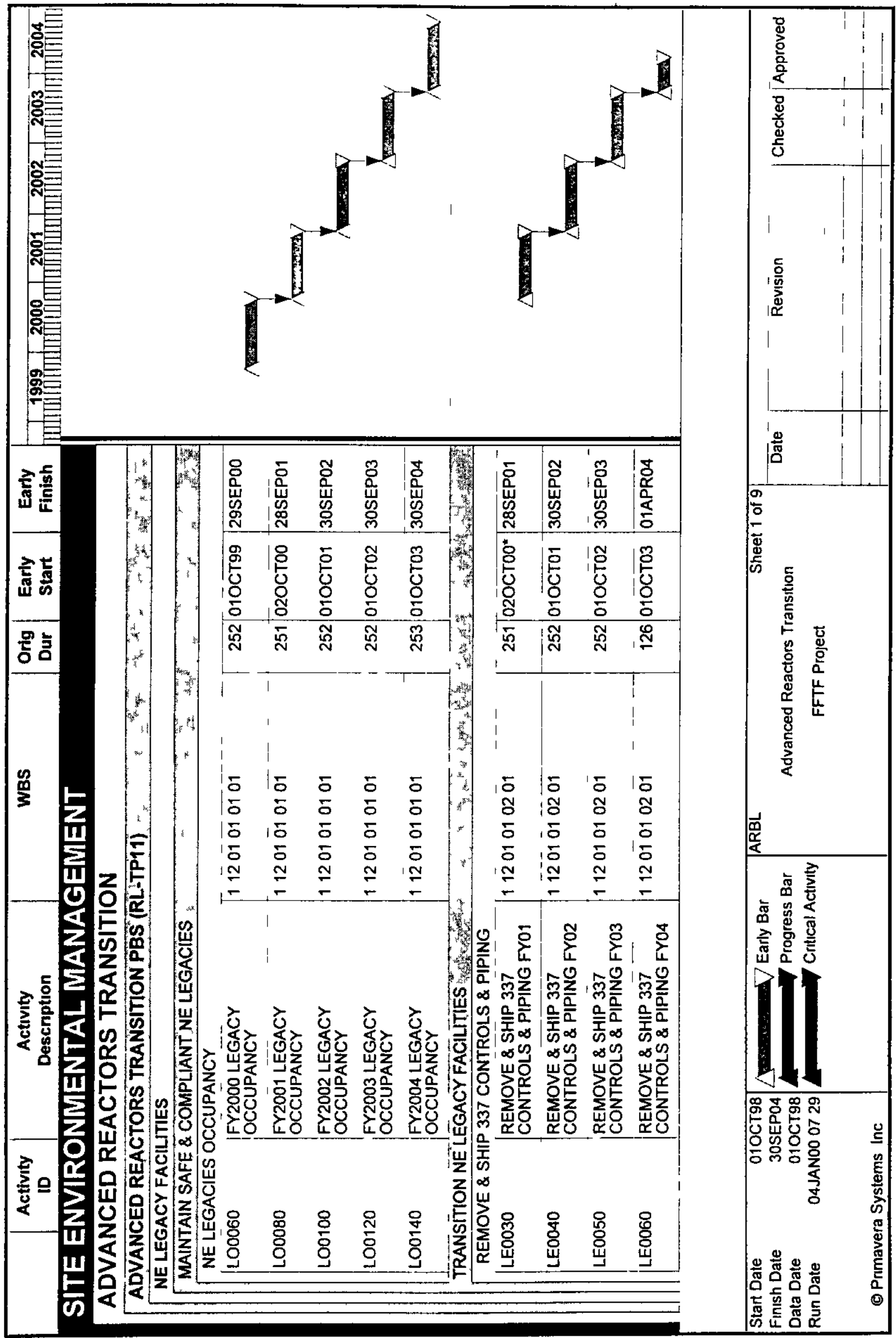




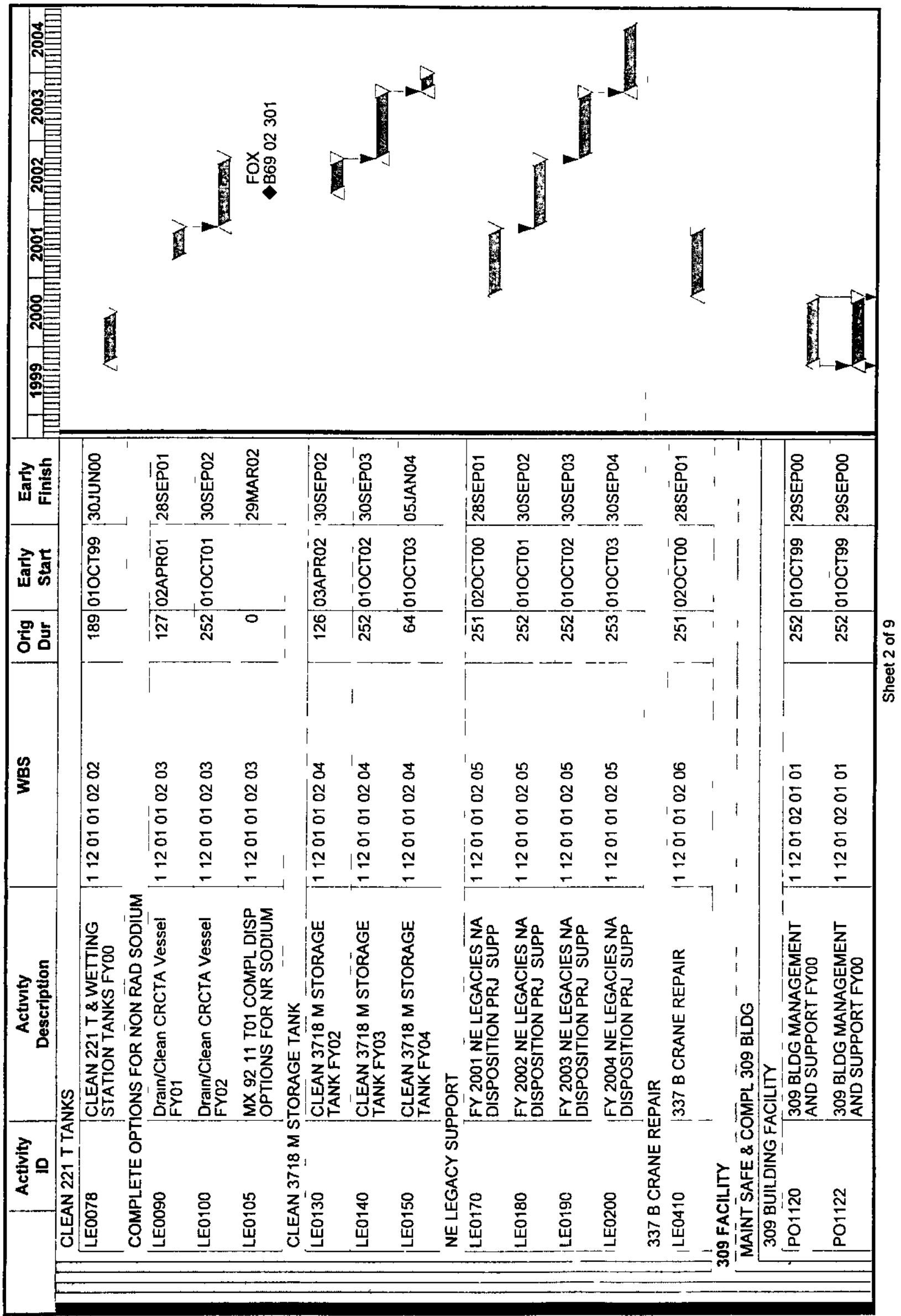




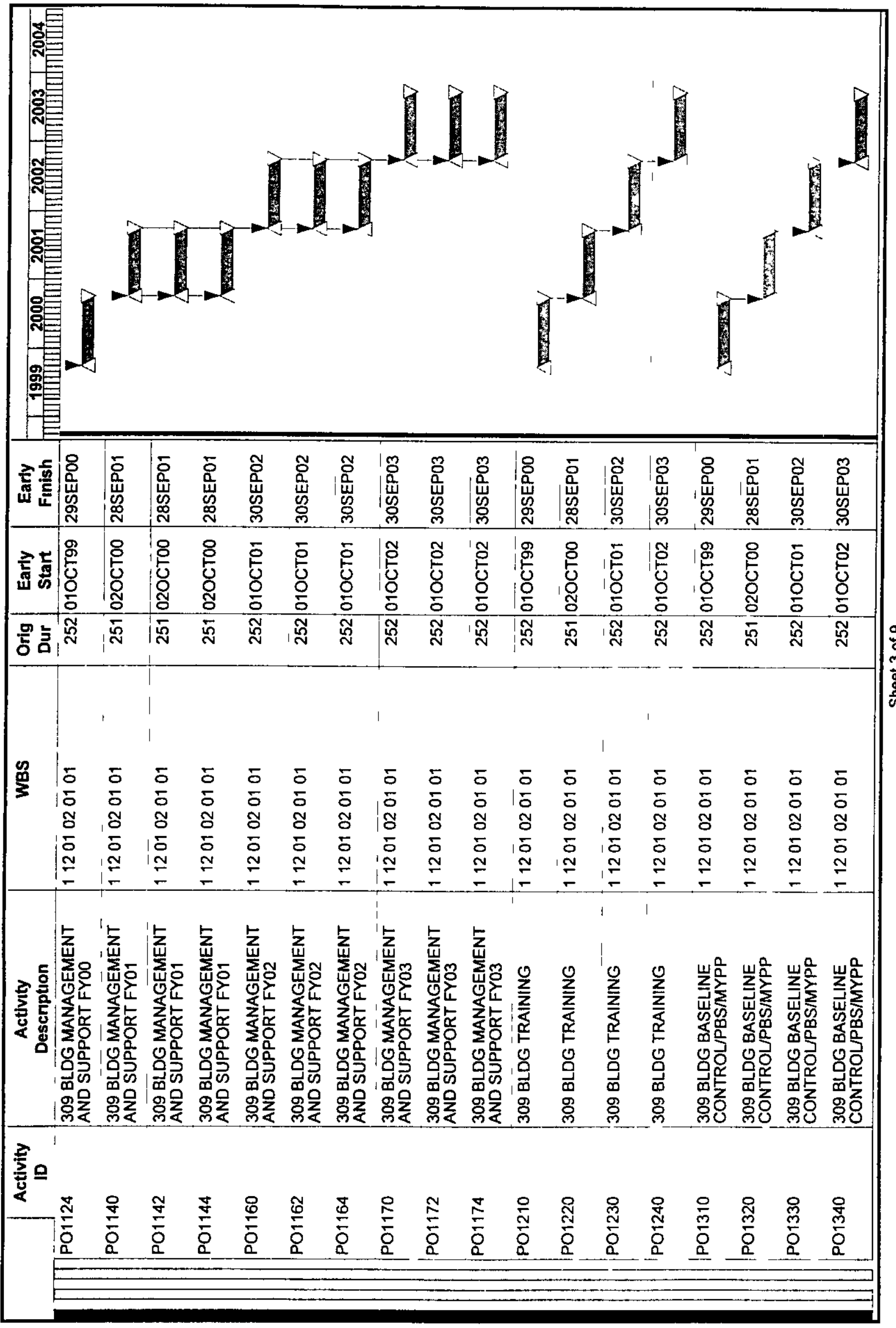




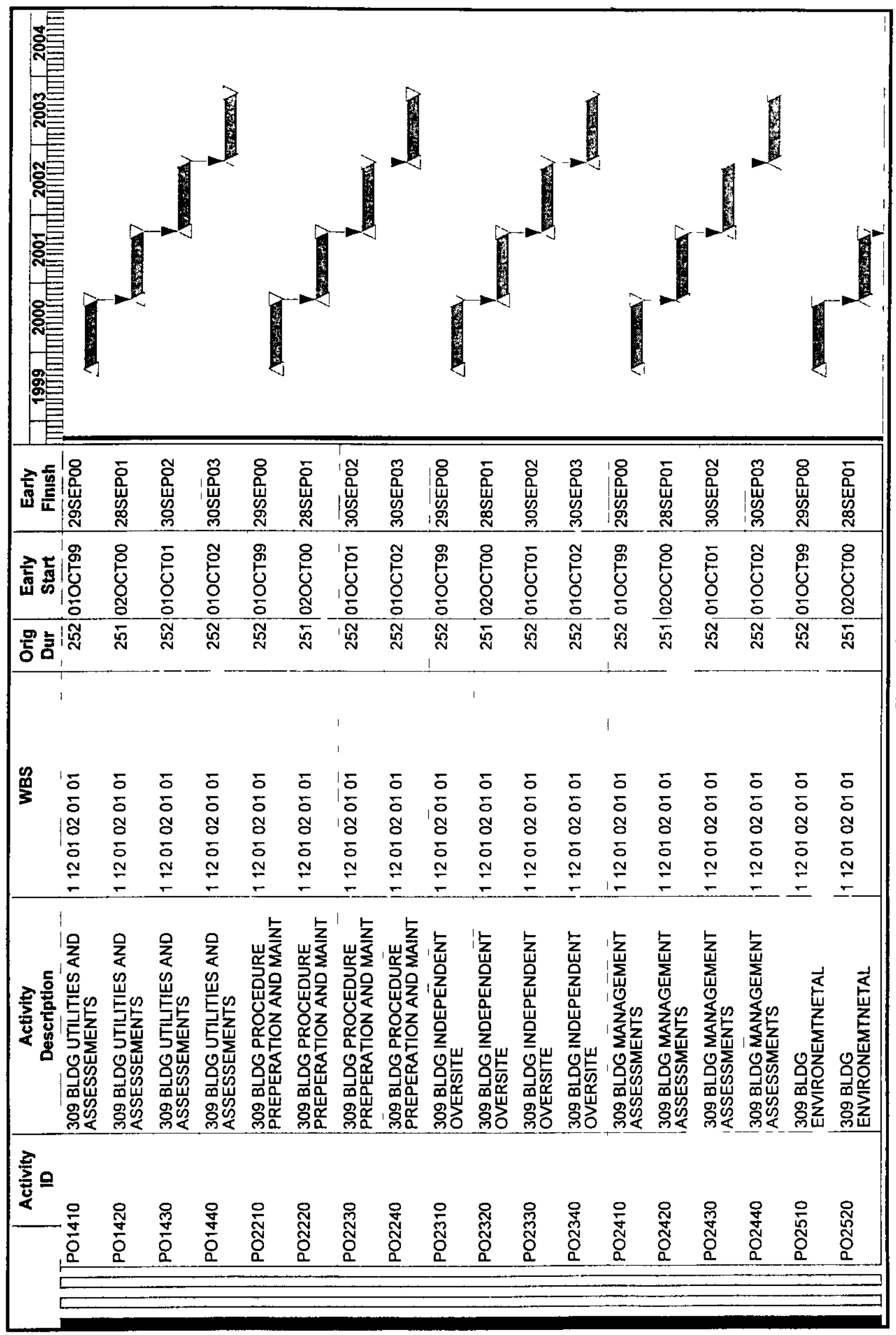




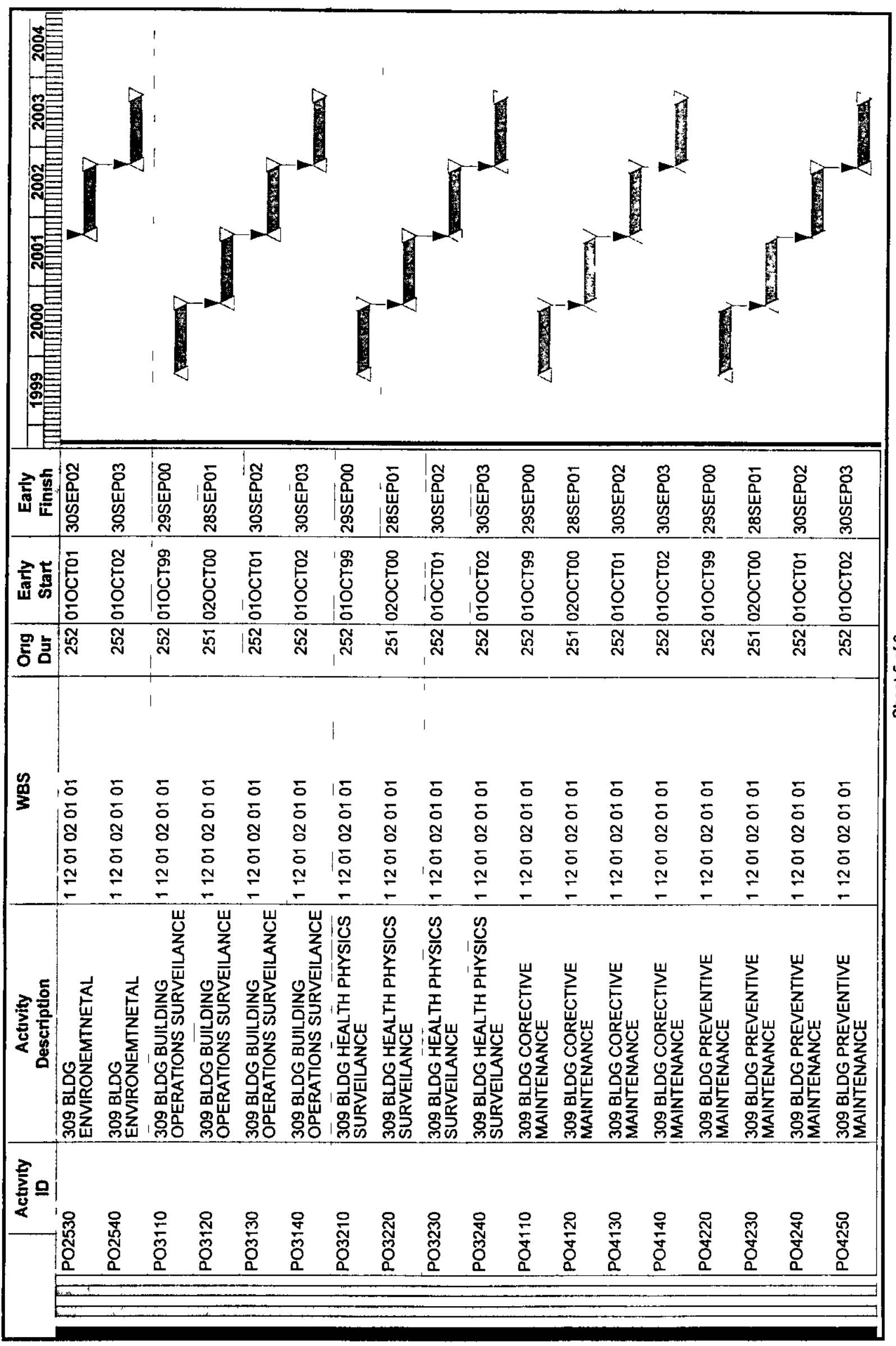




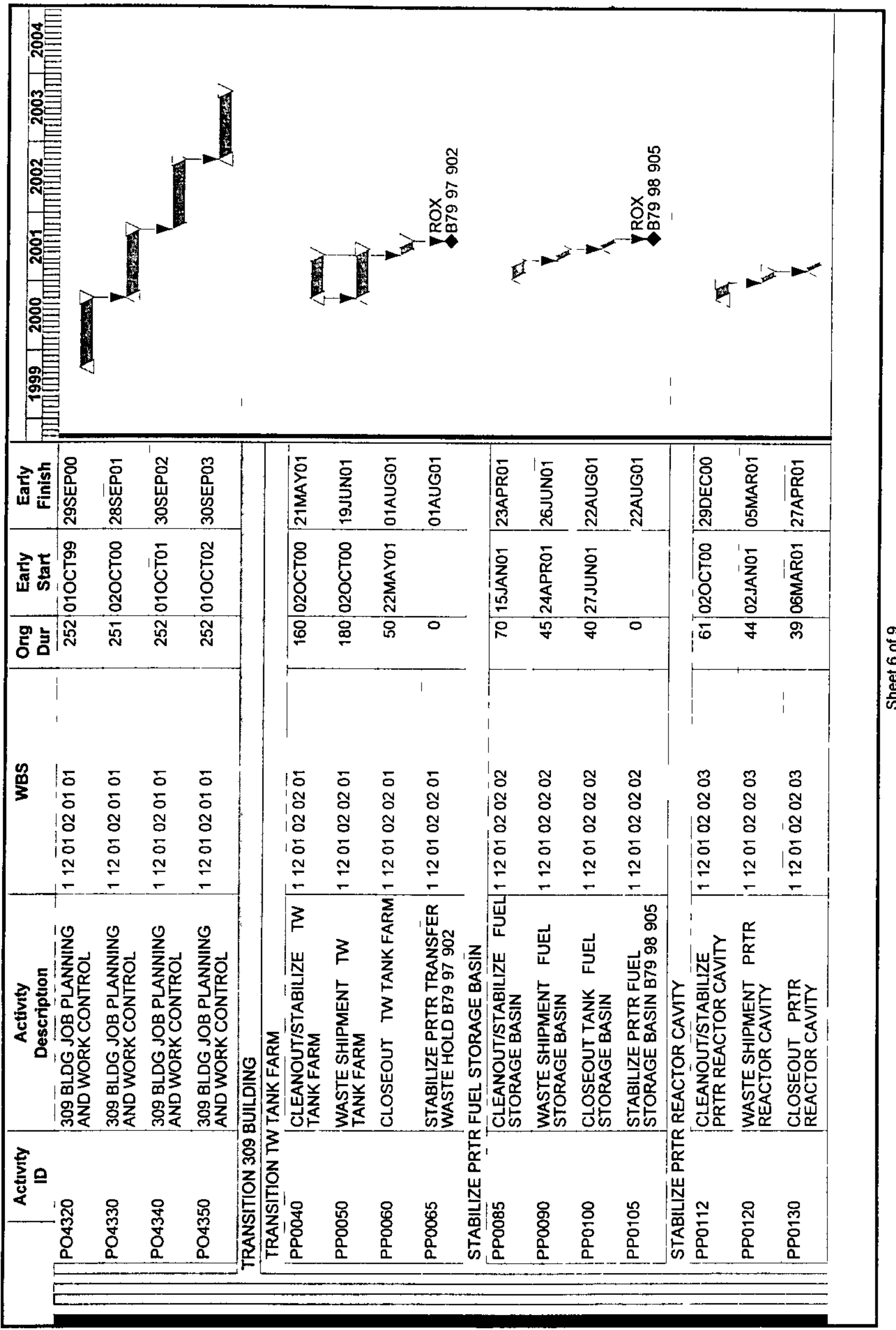




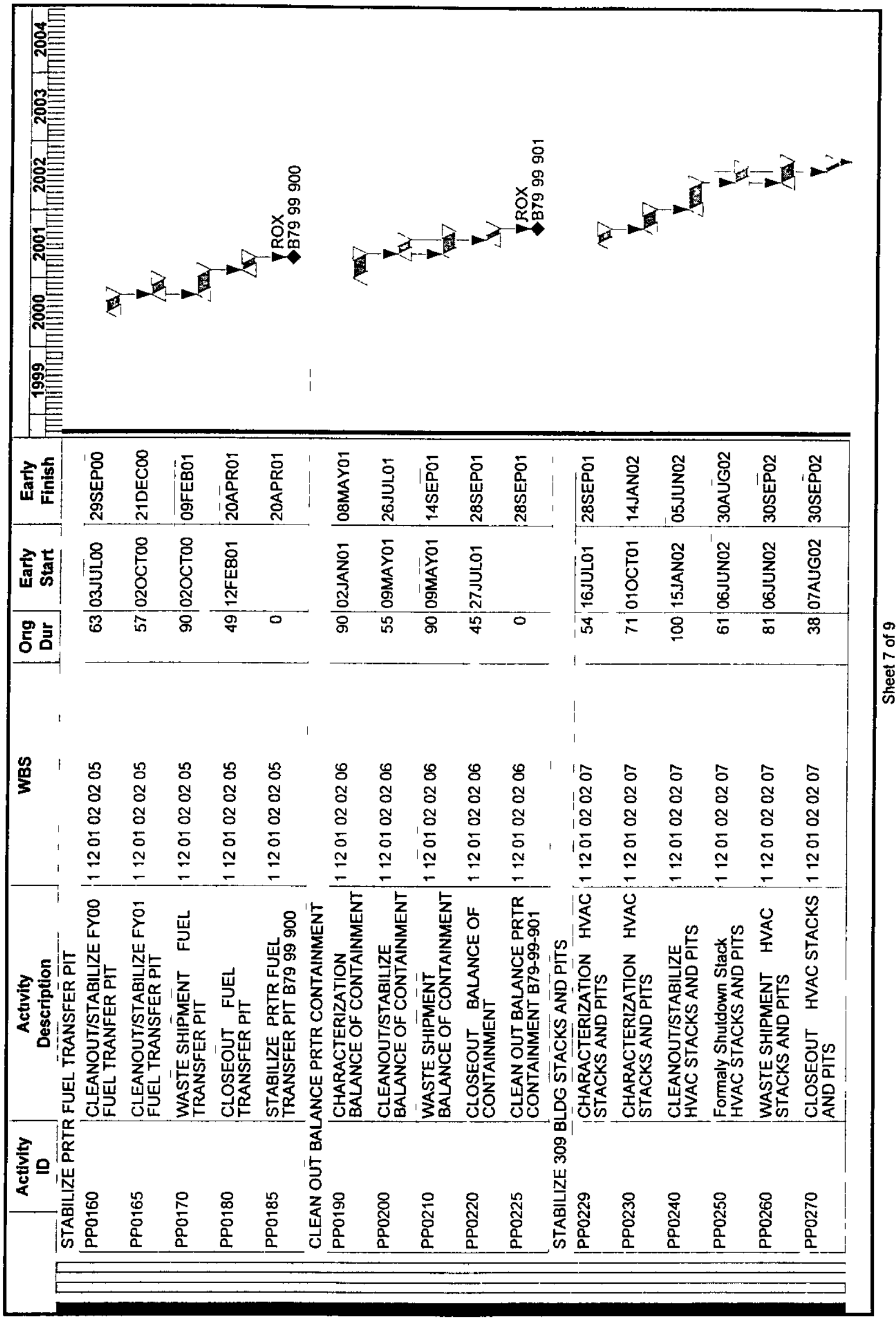




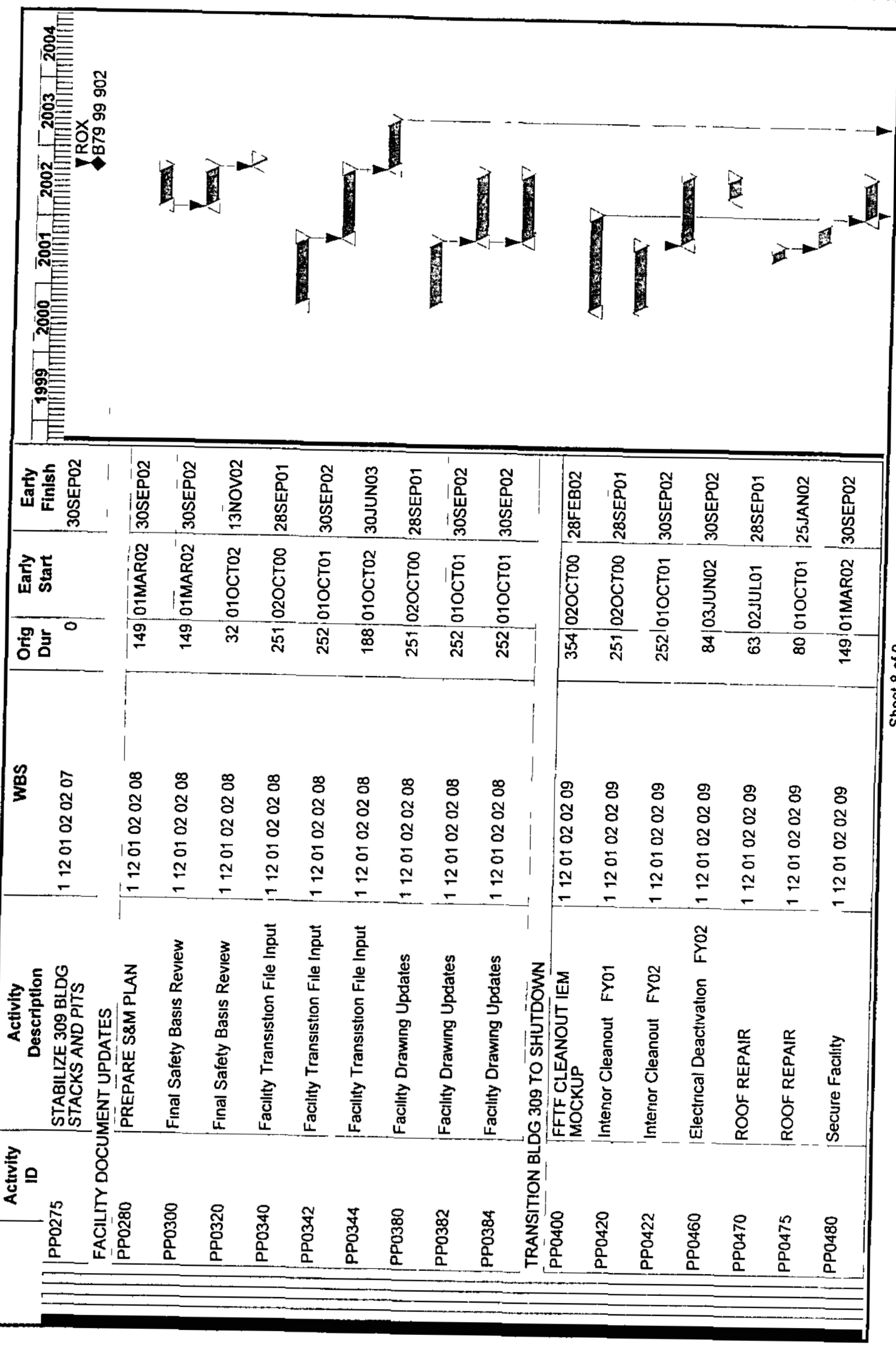




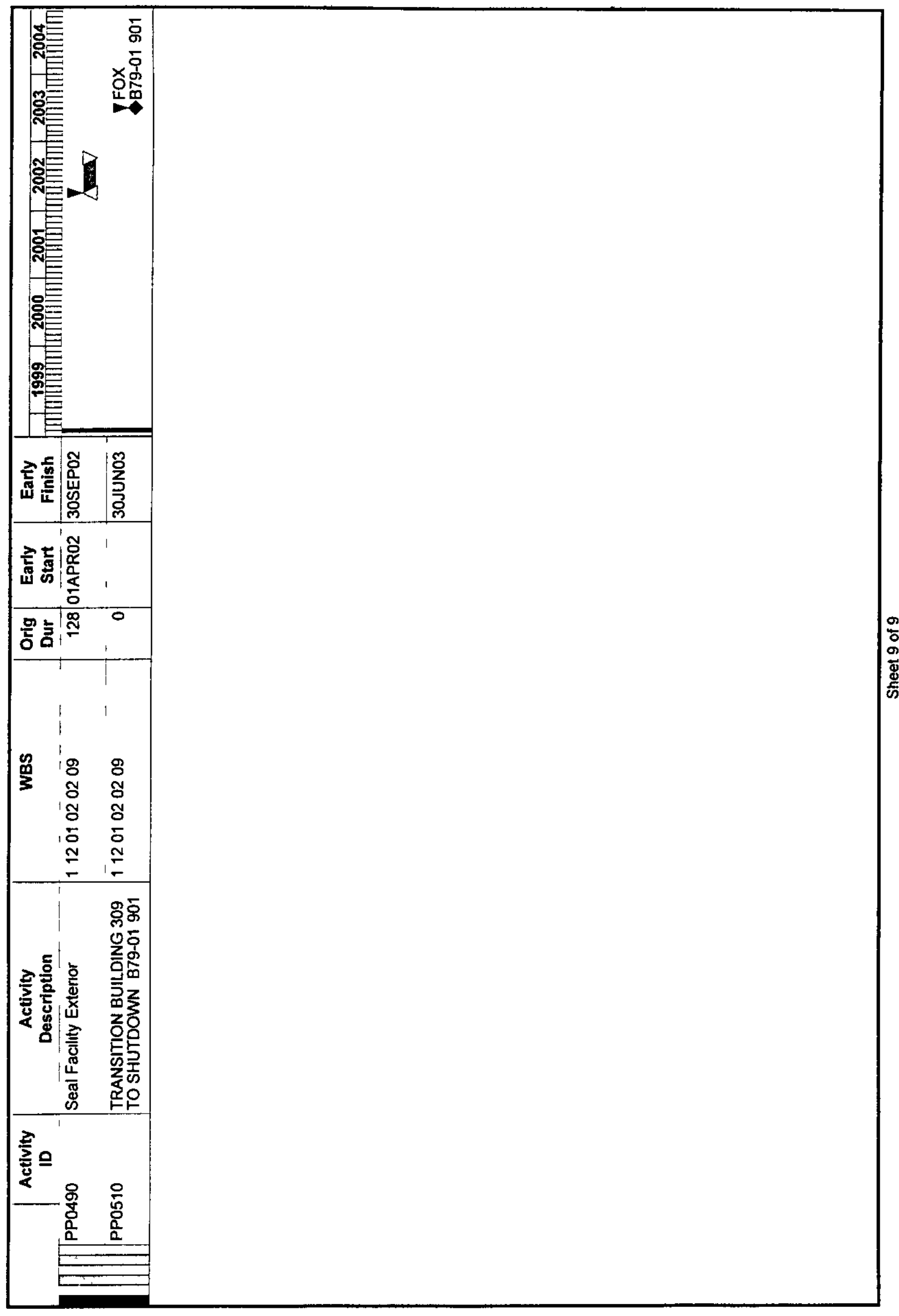


HNF-SD FF-SSP 050

Rev 8 Page 96

THIS CHANGE INTENTIONALLY BLANK 


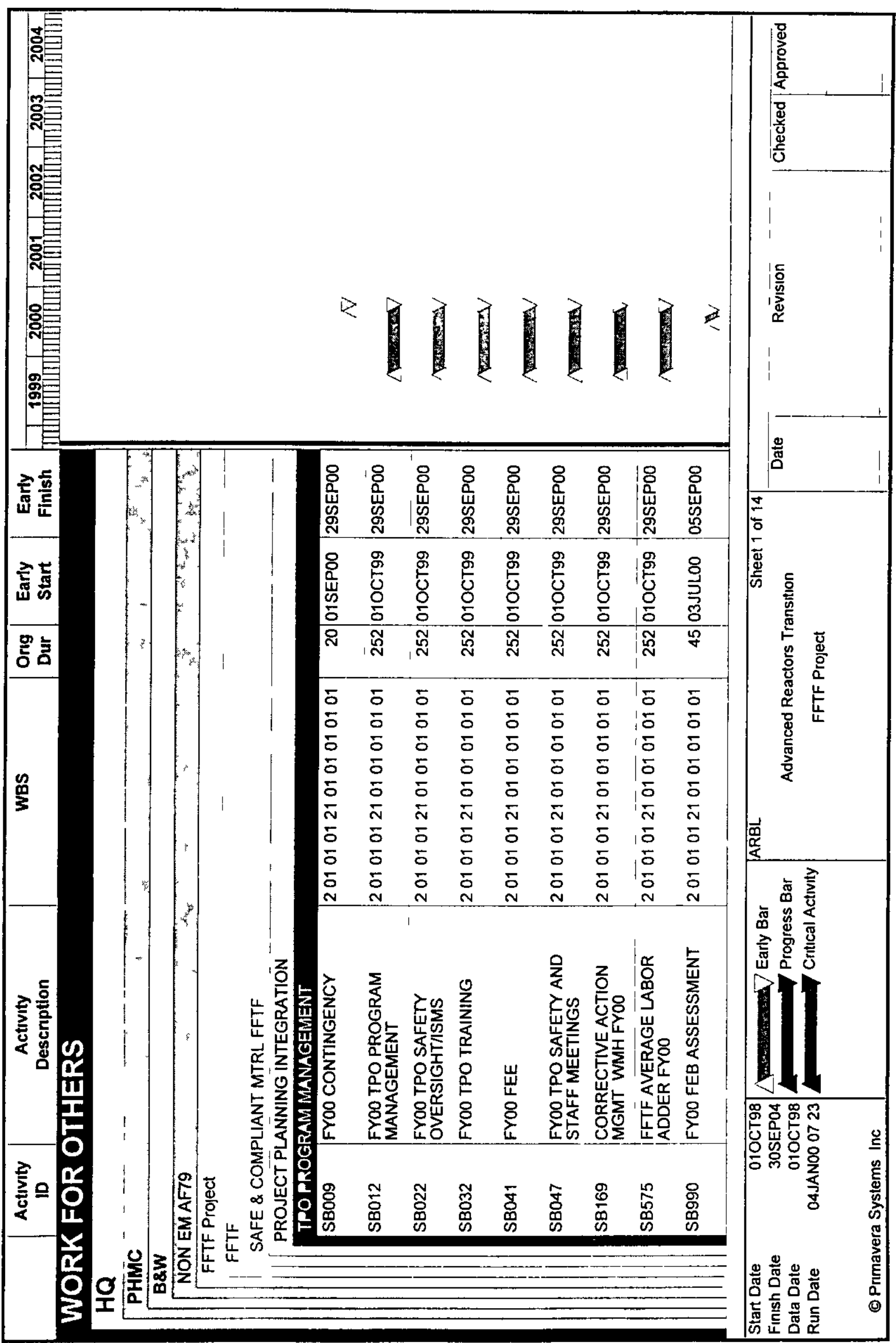




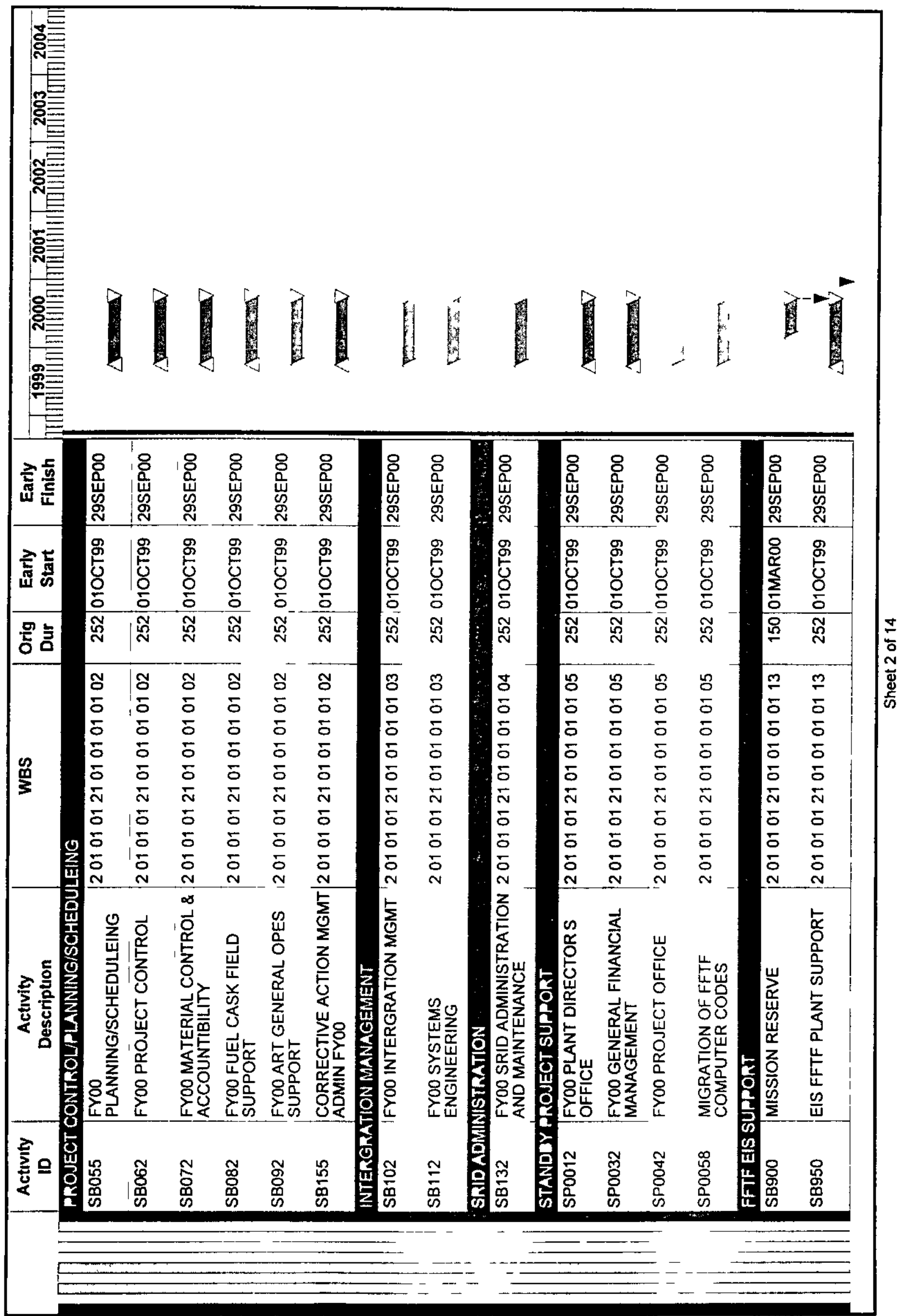




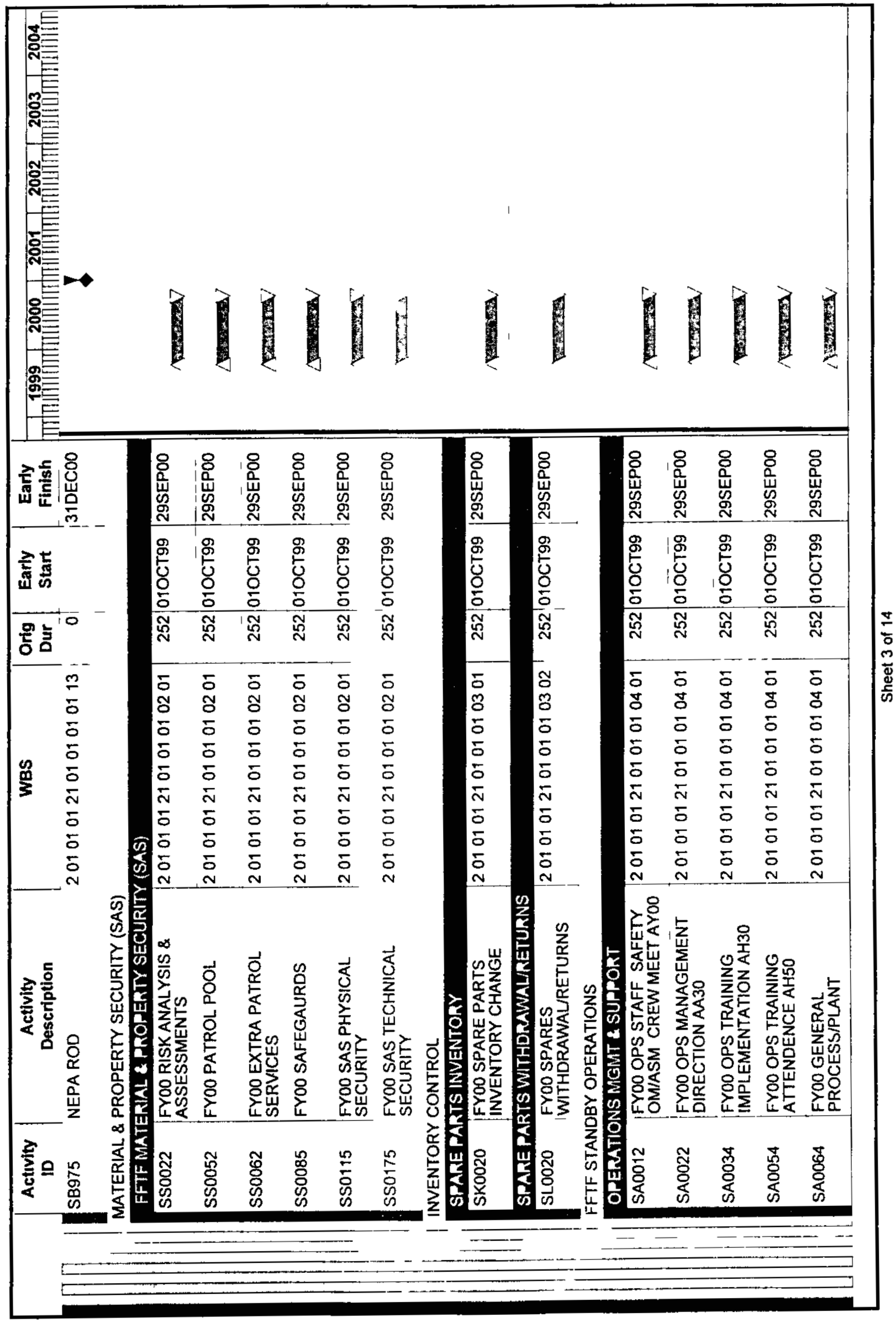




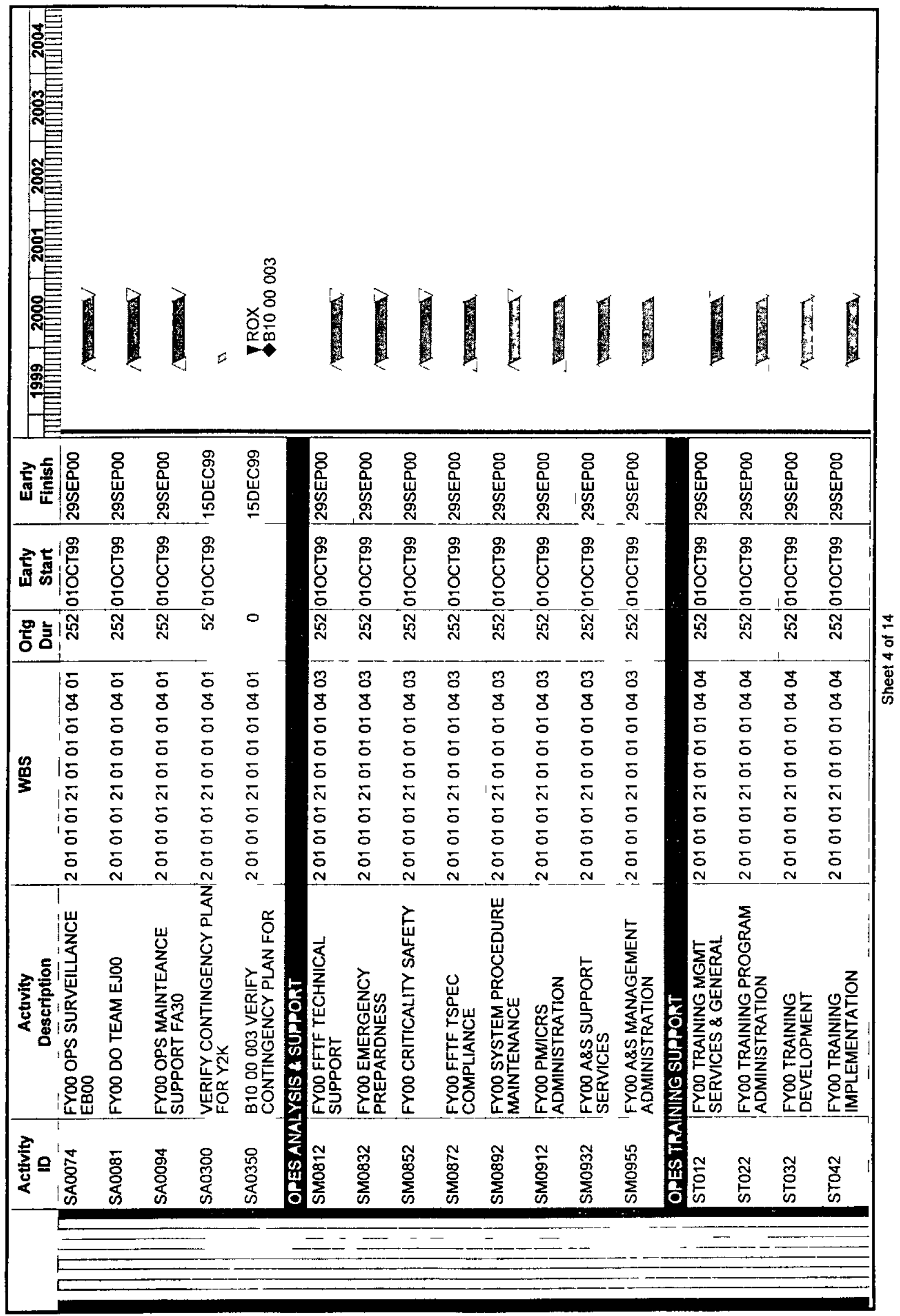




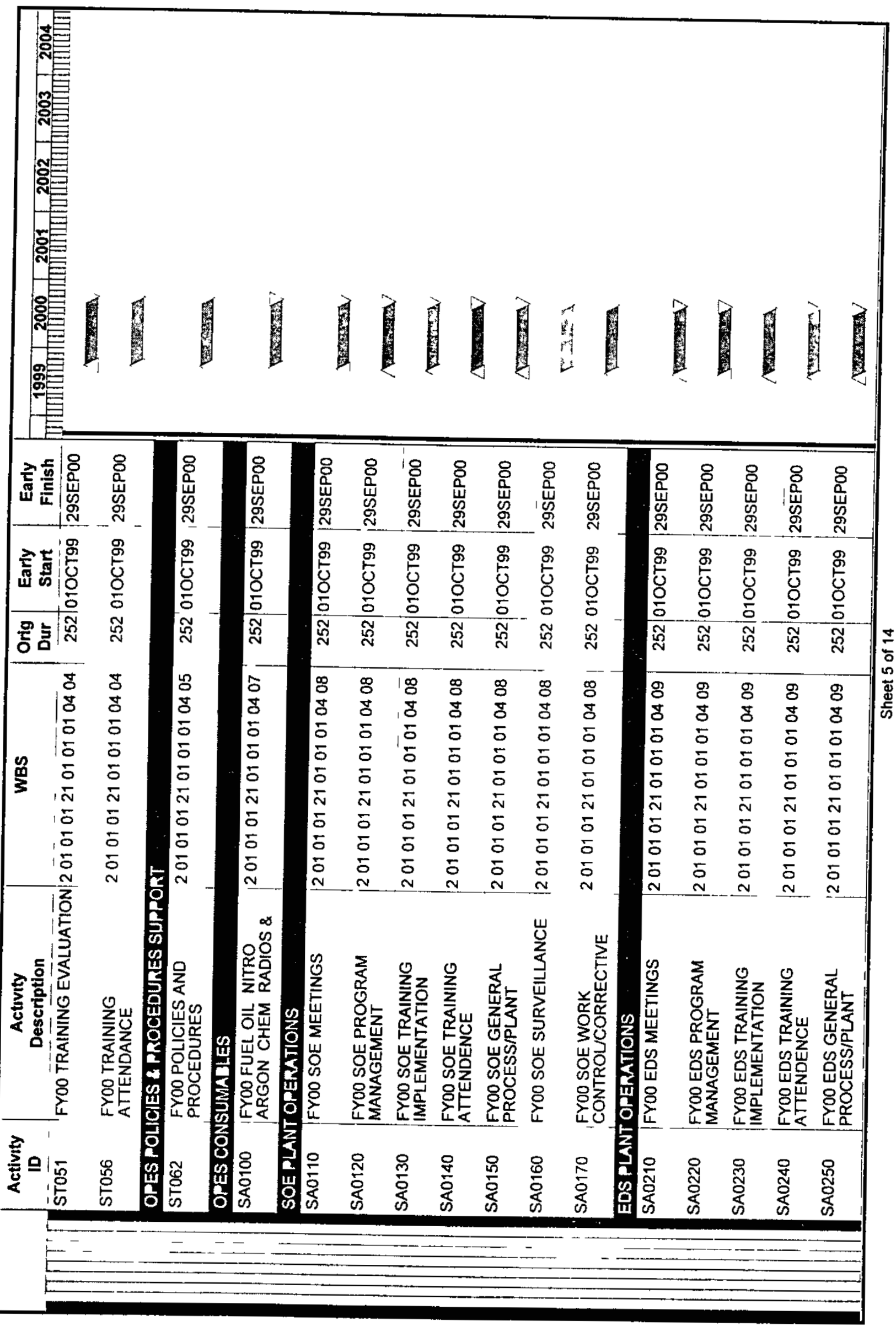




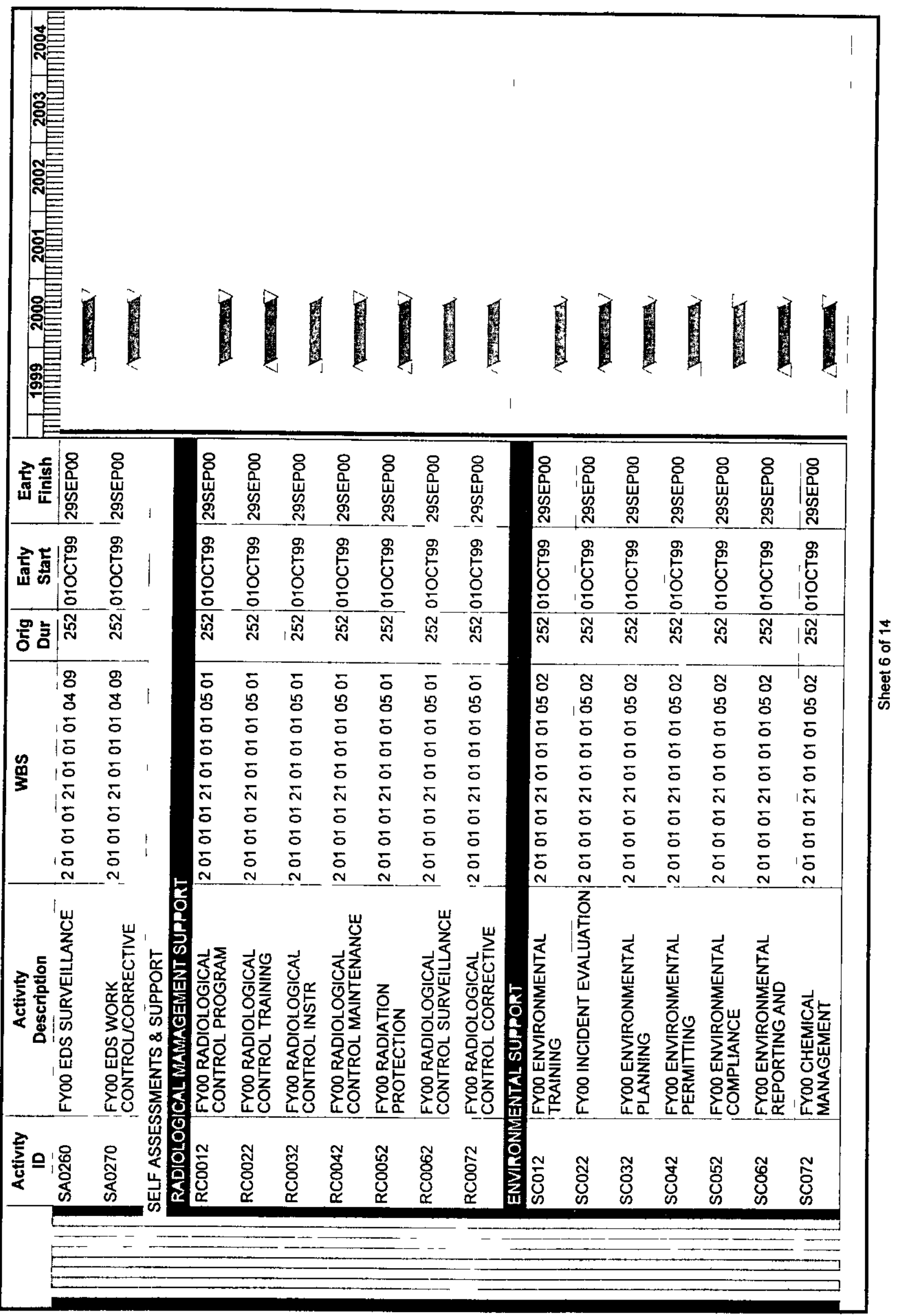




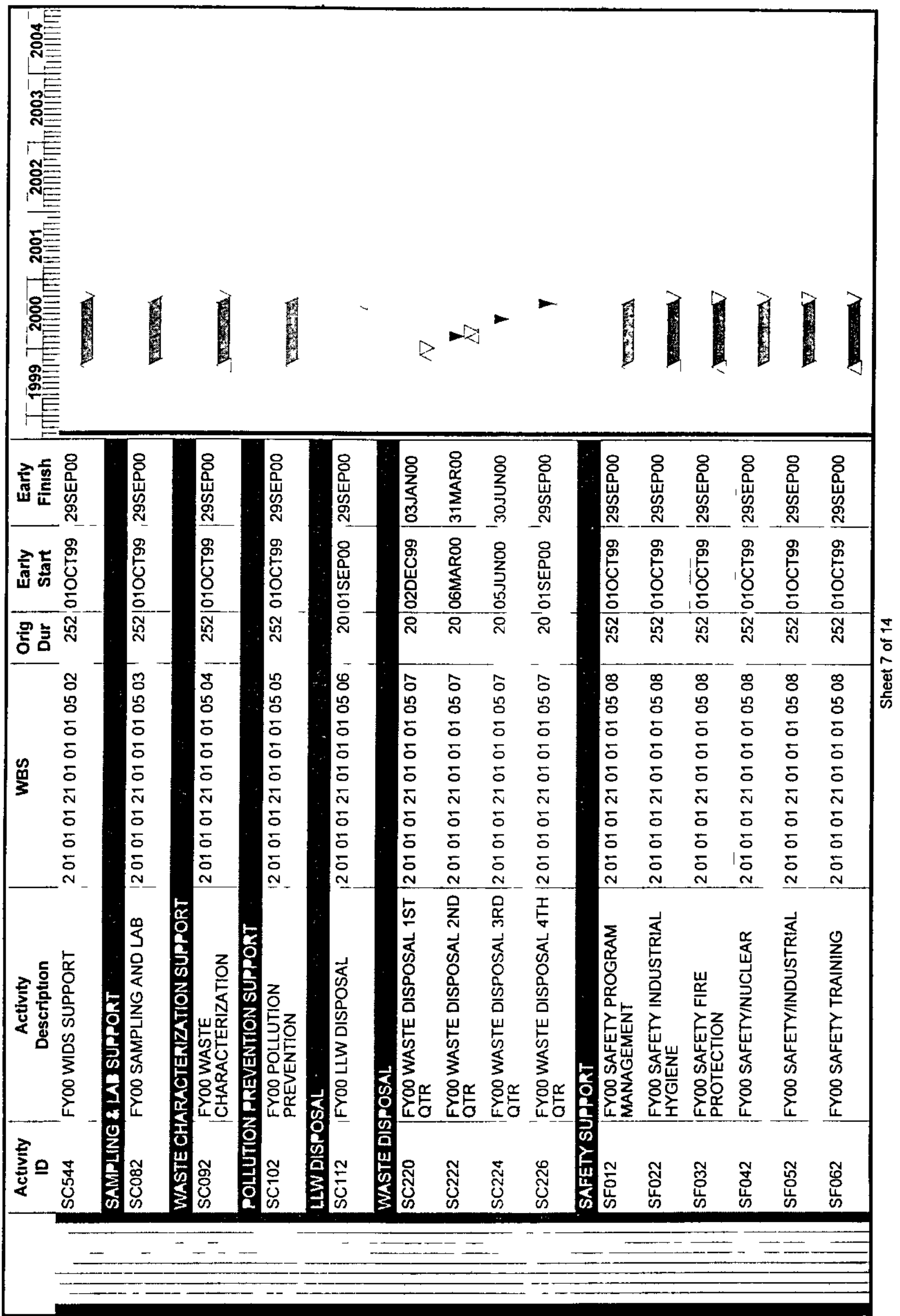




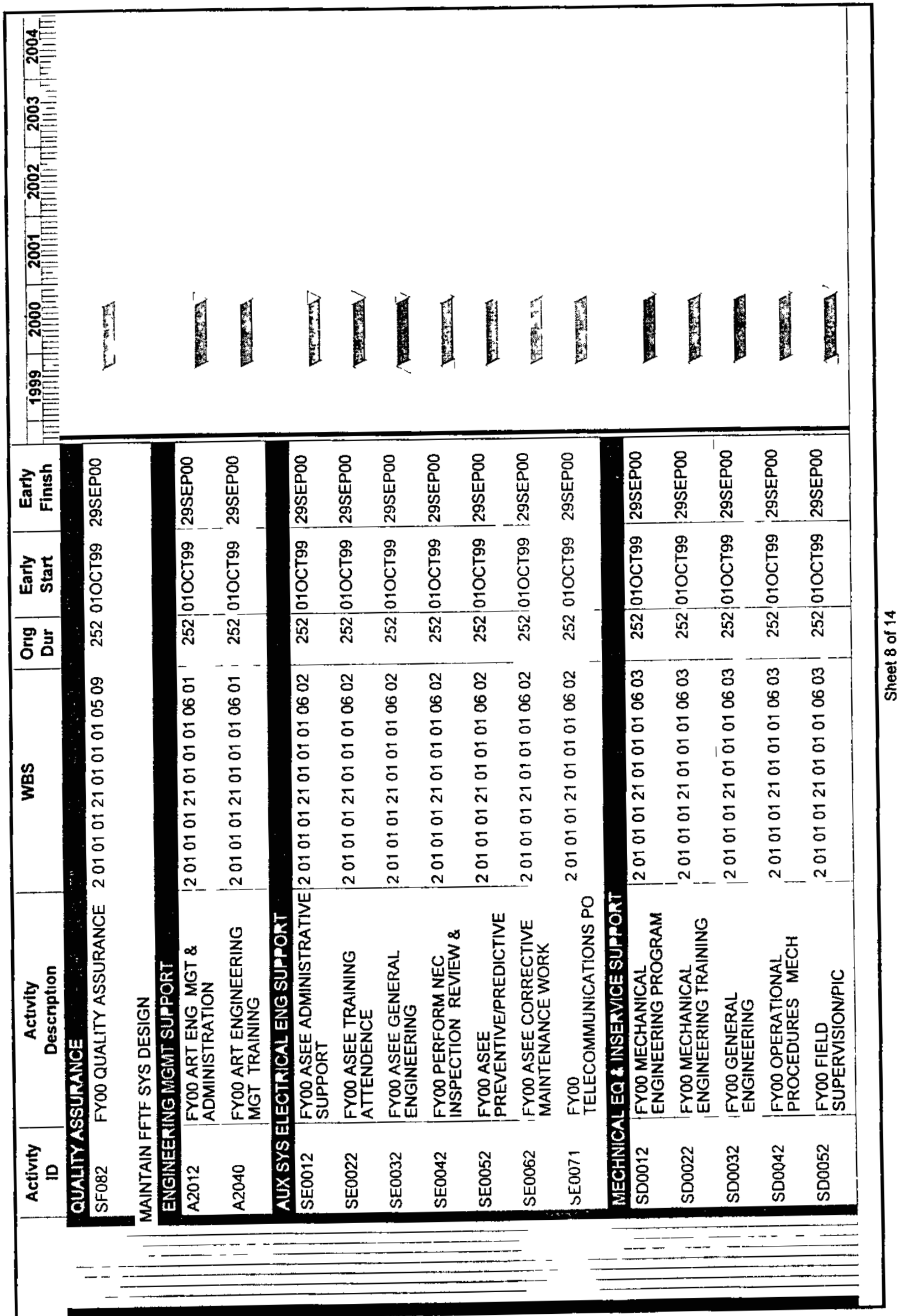




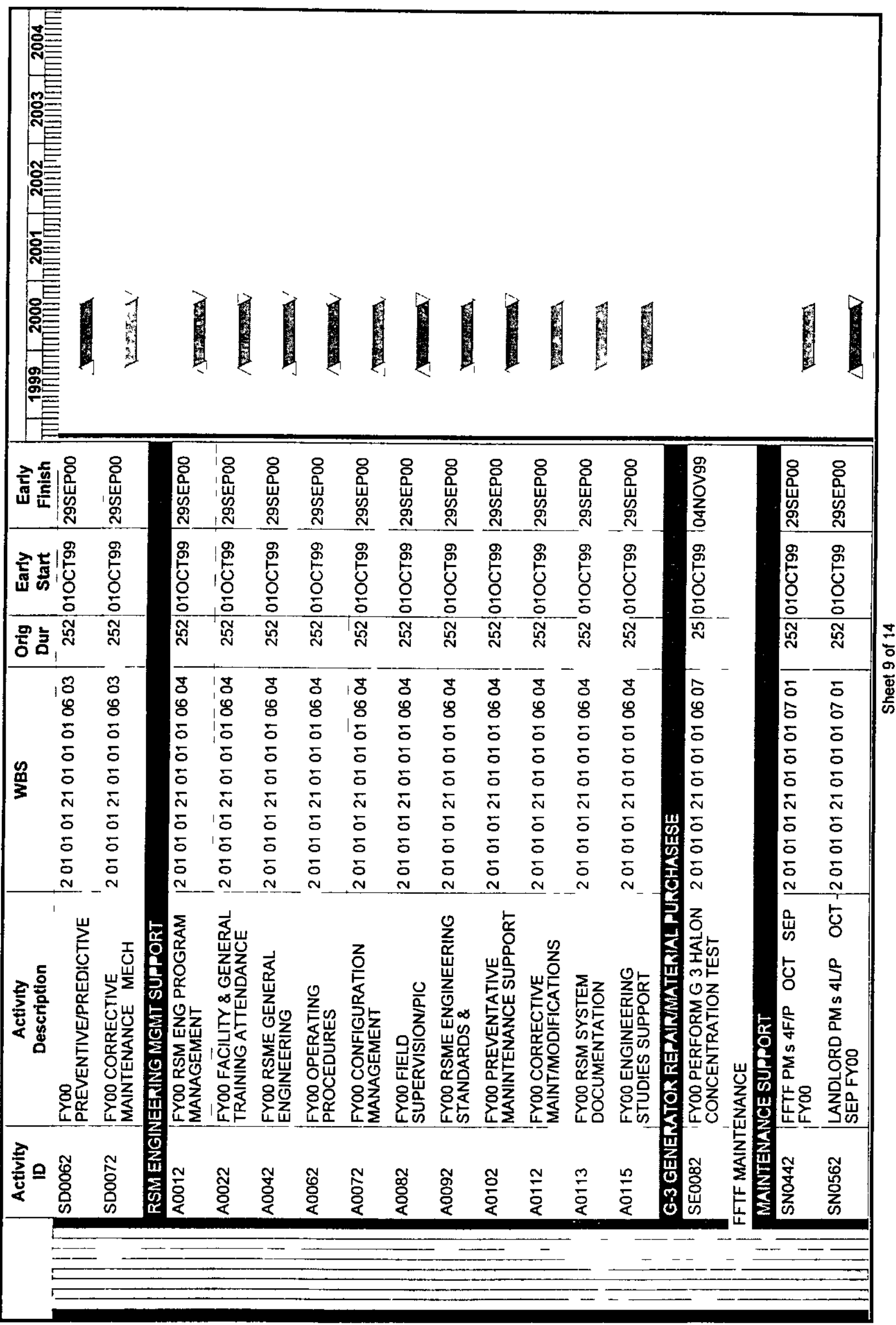




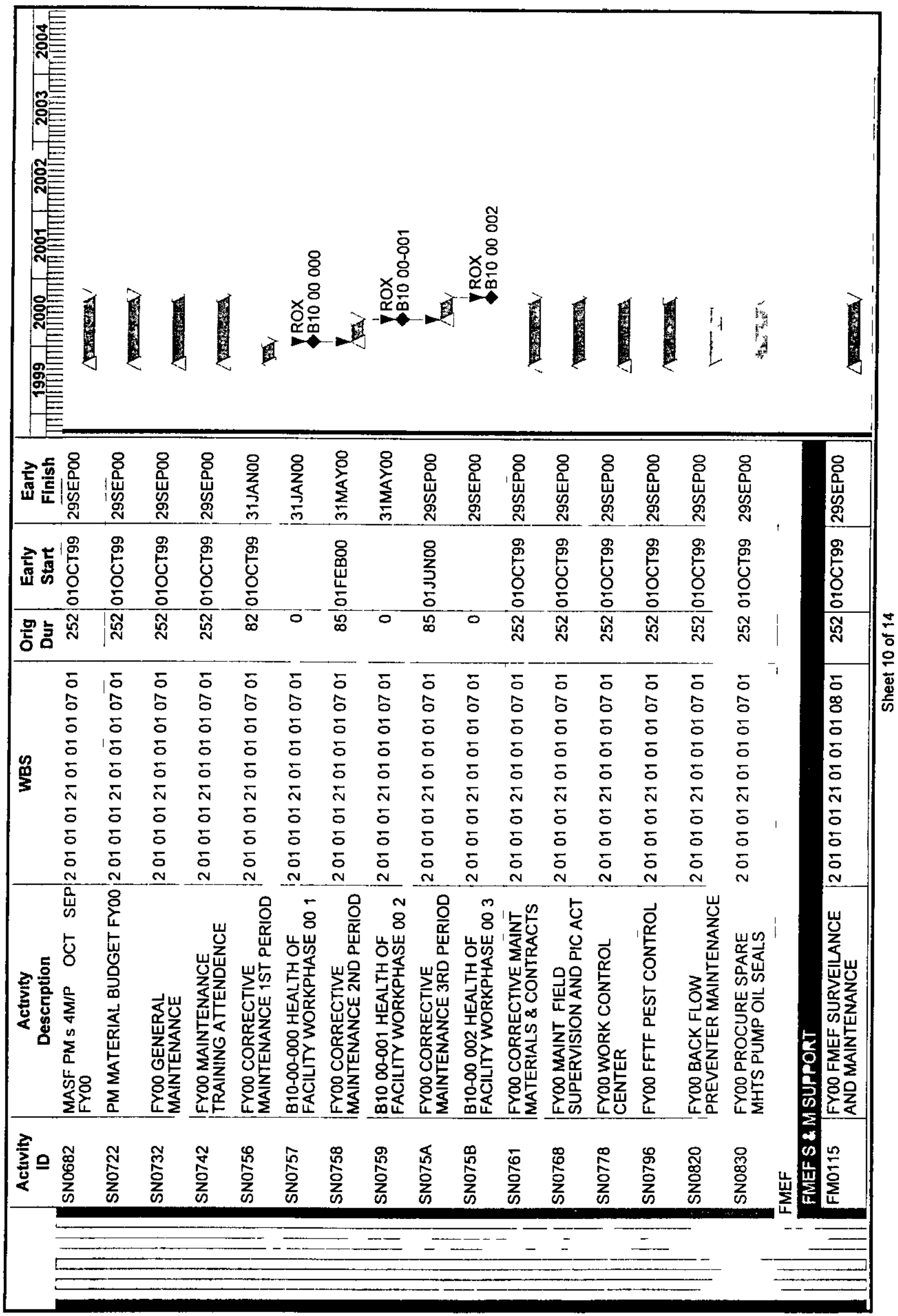




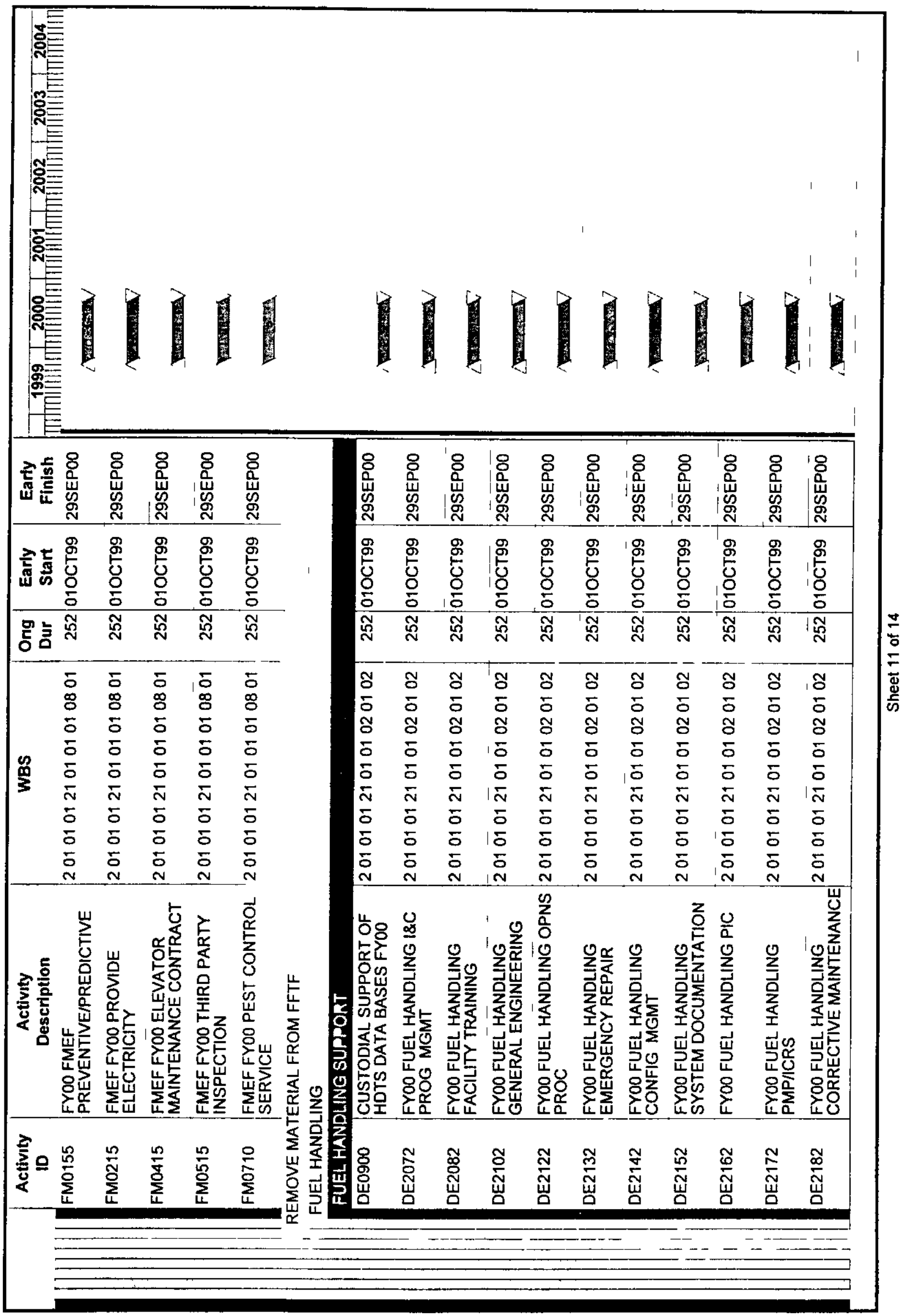




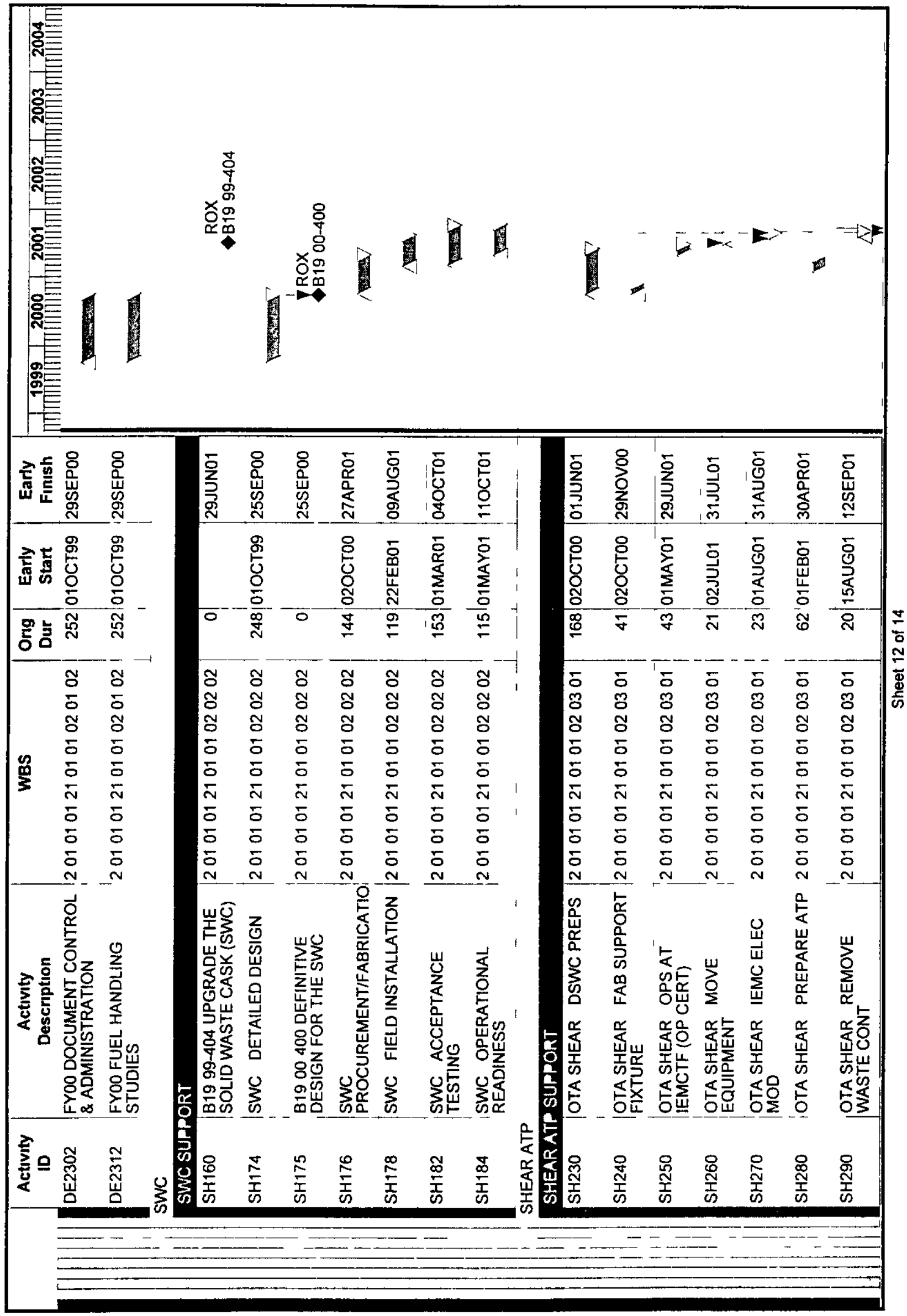




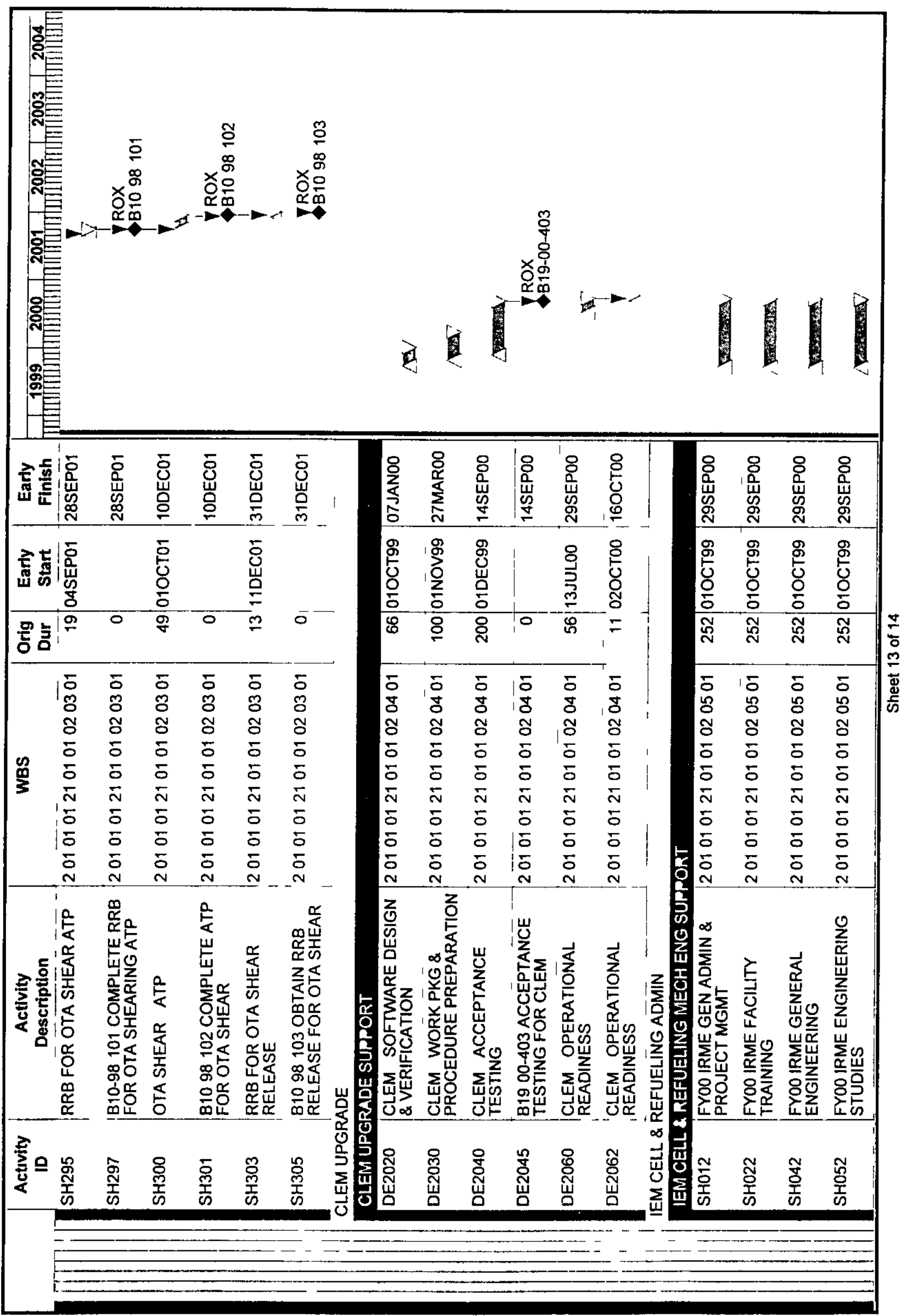




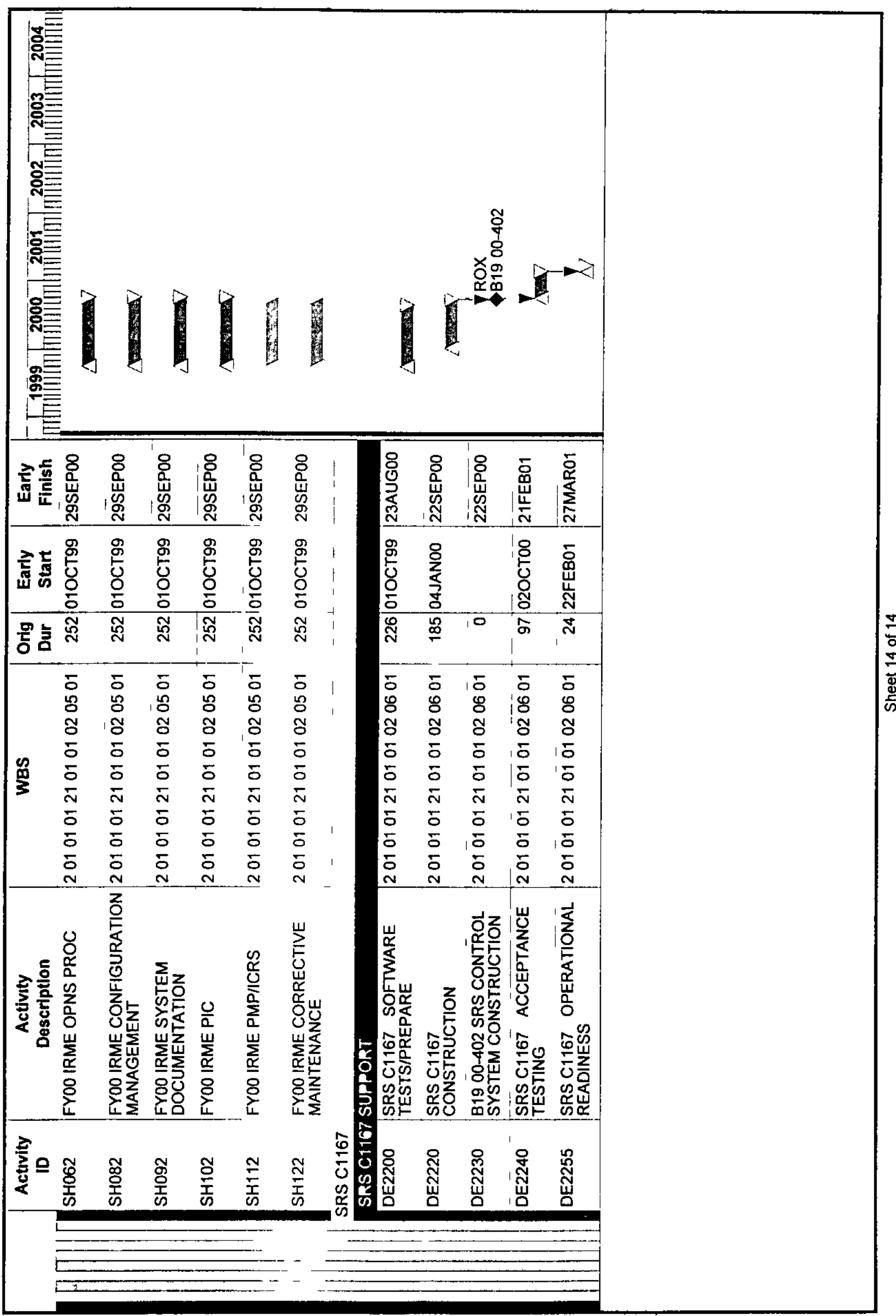




\section{APPENDIX B}

USAGE AND COSTS

Project

Page

Advanced Reactors Transition

FY 2000

NE Legacy Facilities

113

309 Building Facility

FY 2001

NE Legacy Facilities

119

309 Bullding Facility

123

FY 2002

NE Legacy Facilities

135

309 Building Facility

140

FY 2003

NE Legacy Facisties

309 Buildıng Facılity

149

FY 2004

NE Legacy Facilities

153

Fast Flux Test Facility

157 
THIS CHANGE INTENTIONALLY BLANK 


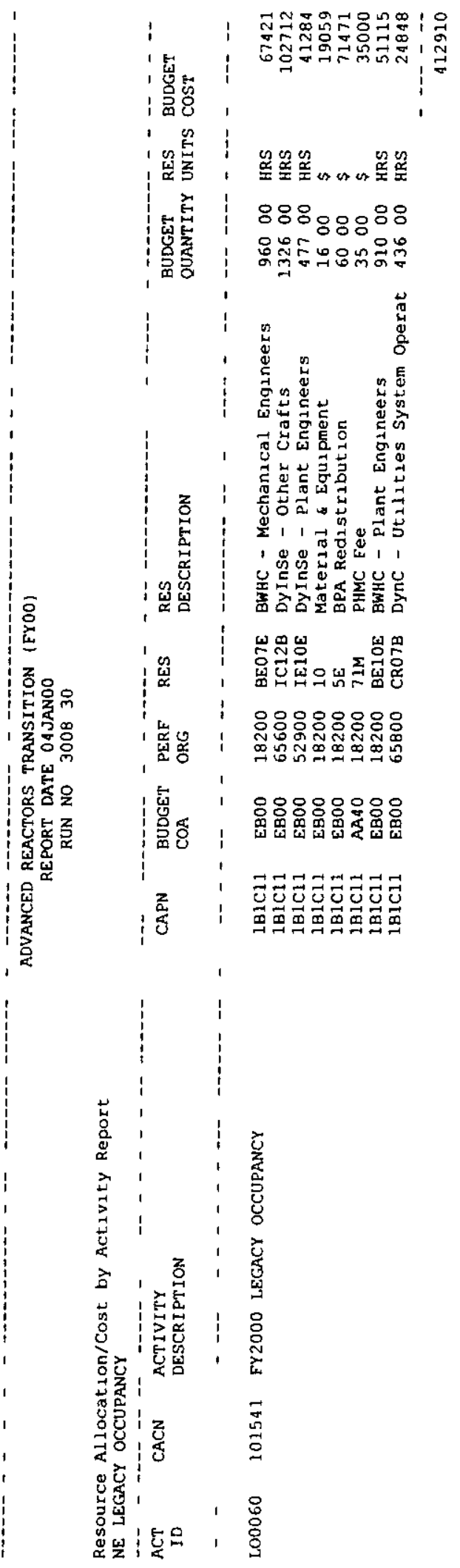




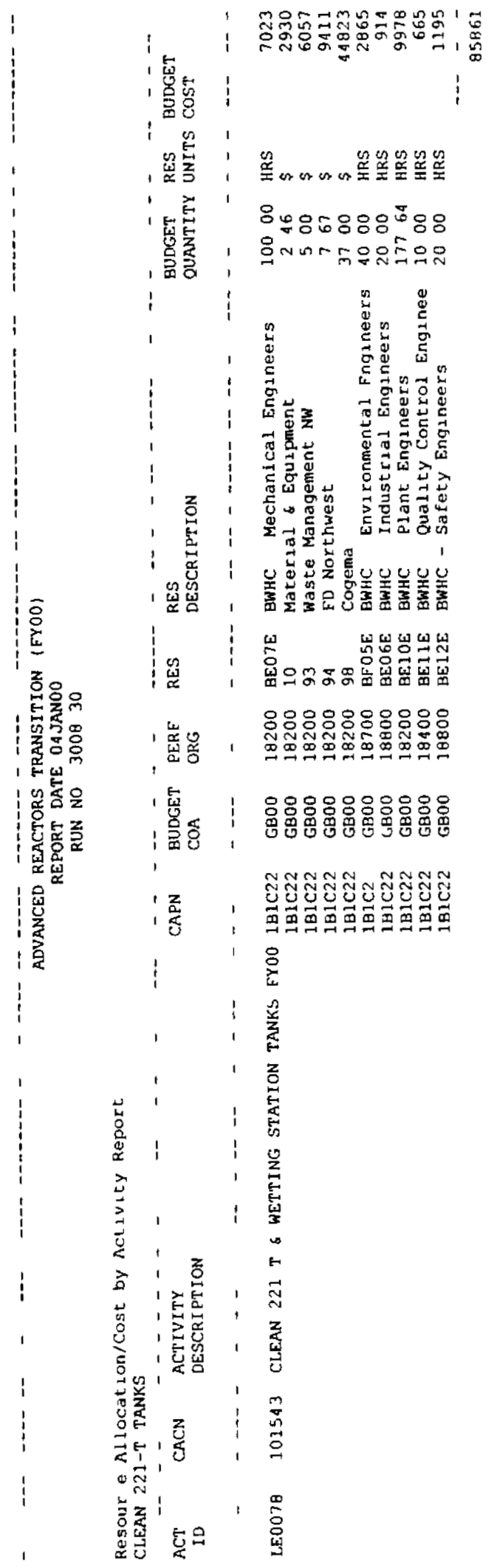


莺最

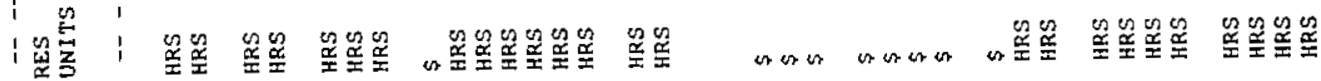
'在

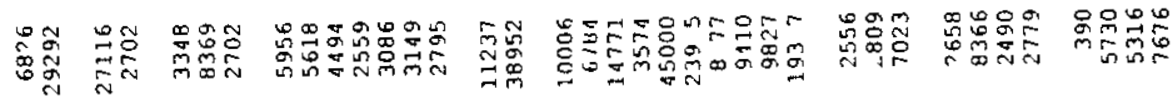

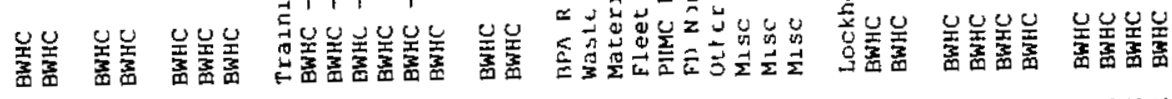
(

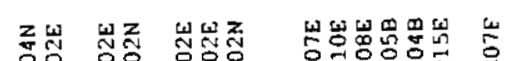

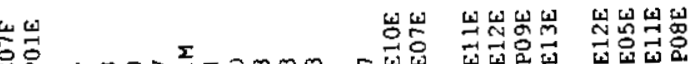

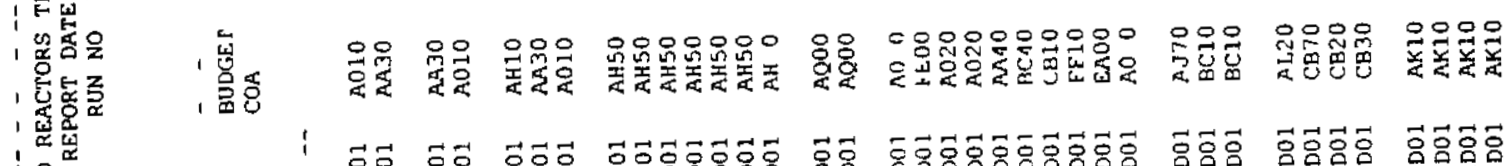

.

位

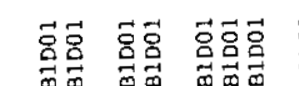

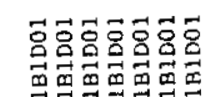

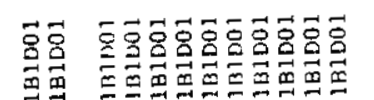

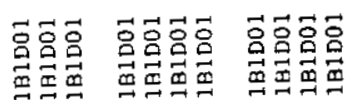

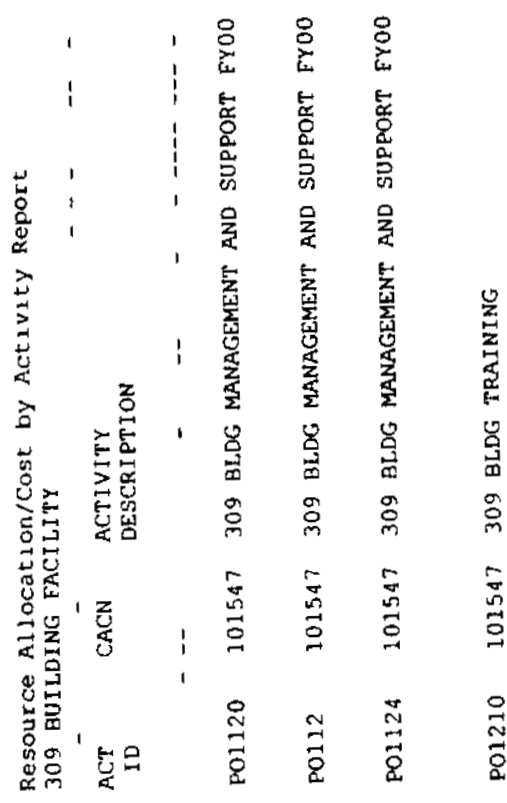

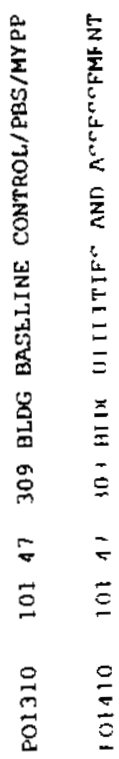

齿

1
$\vdots$
$\vdots$
1
$\vdots$
$\vdots$

$$
\text { i }
$$




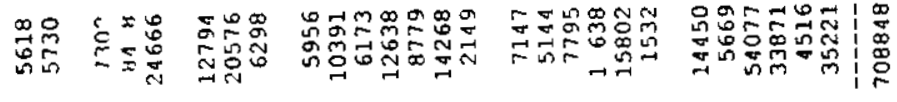

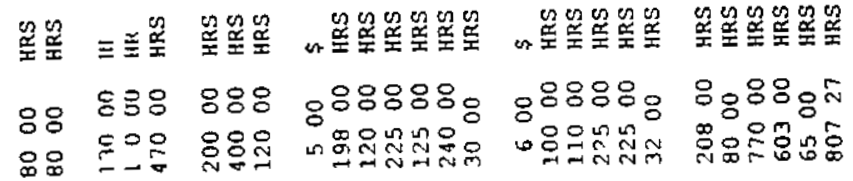

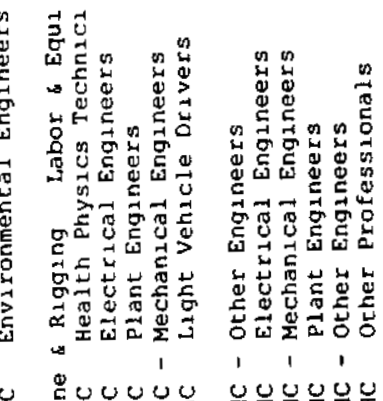

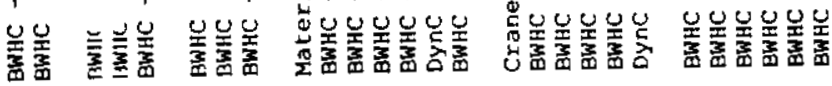

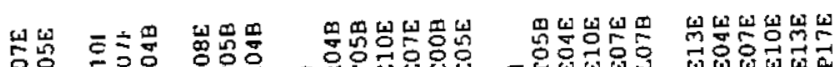

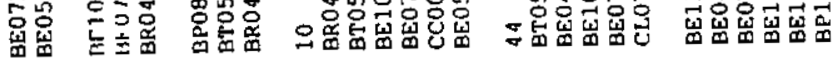

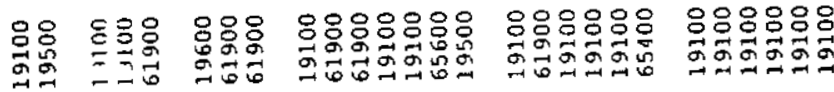

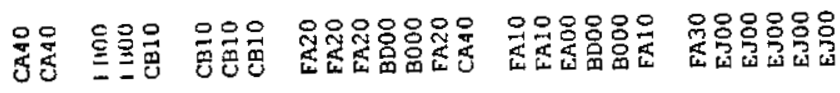

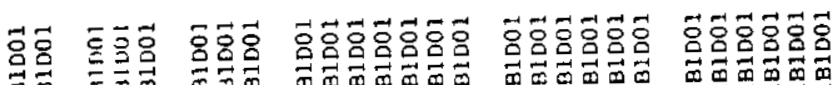

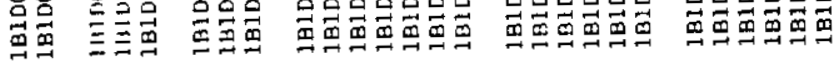

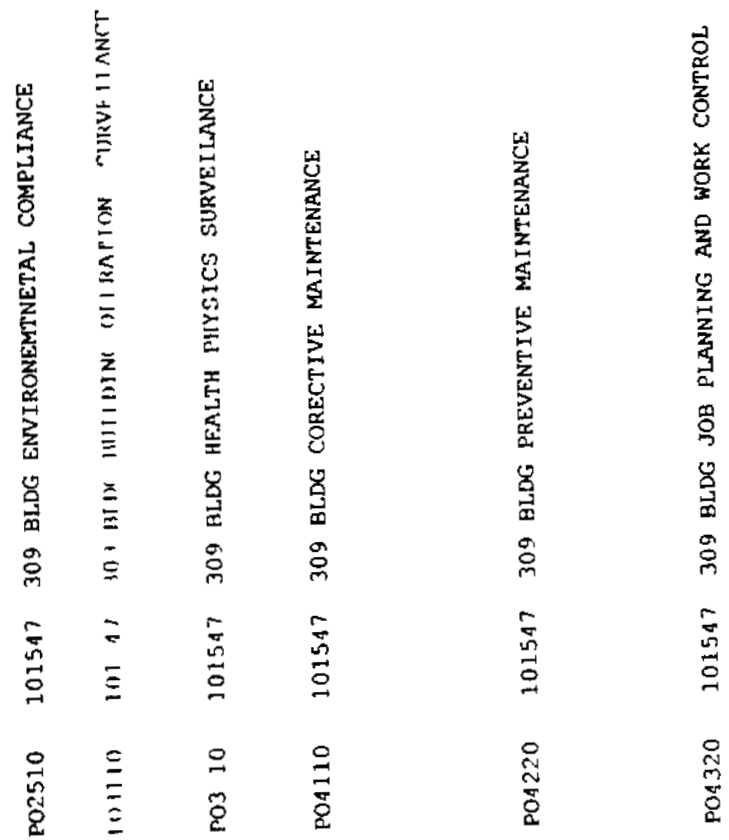




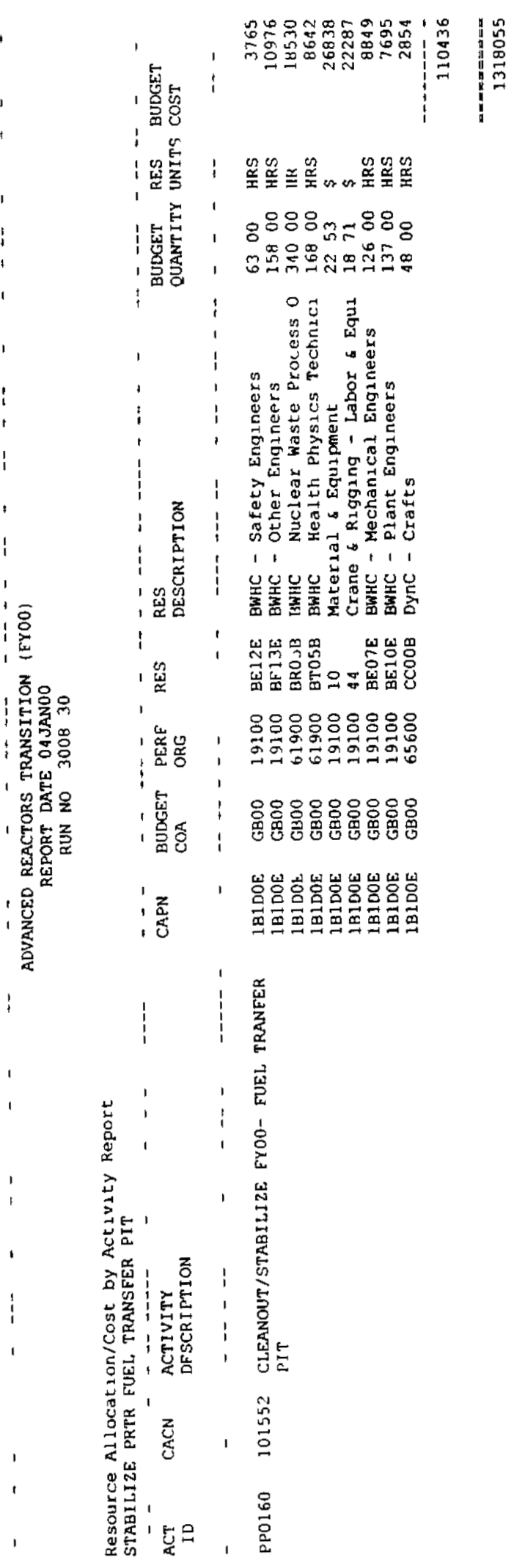


HNF-SD-FF SSP-050

Rev 8 Page 118

THIS CHANGE INTENTIONALLY BLANK 


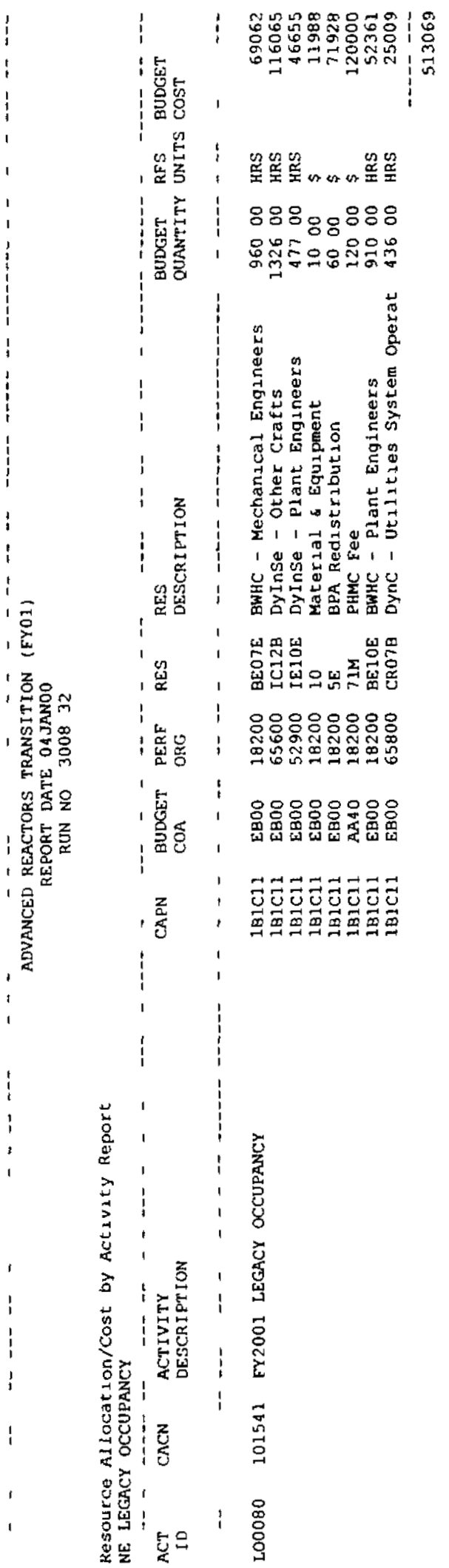




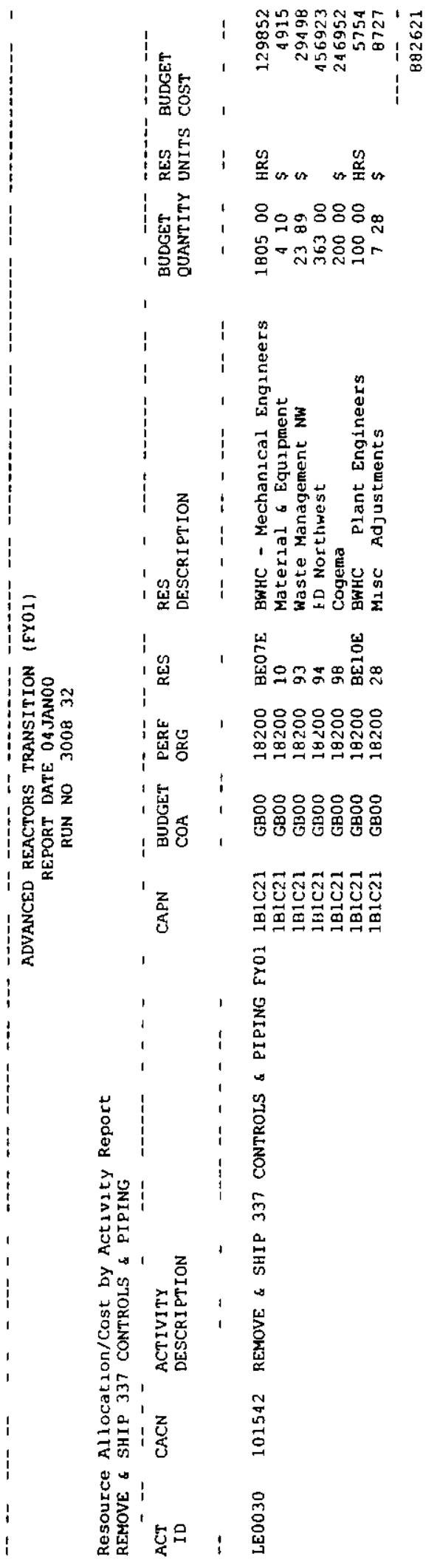


HNF-SD-FF-SSP 050

Rev 8 Page 121

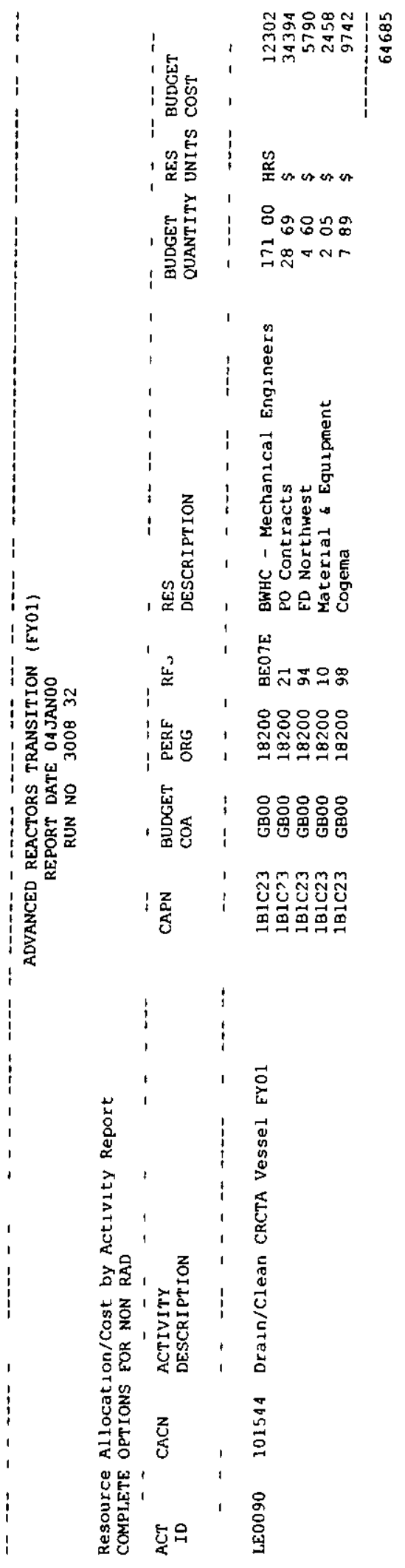


HNF-SD FF SSP 050

Rev 8 Page 122

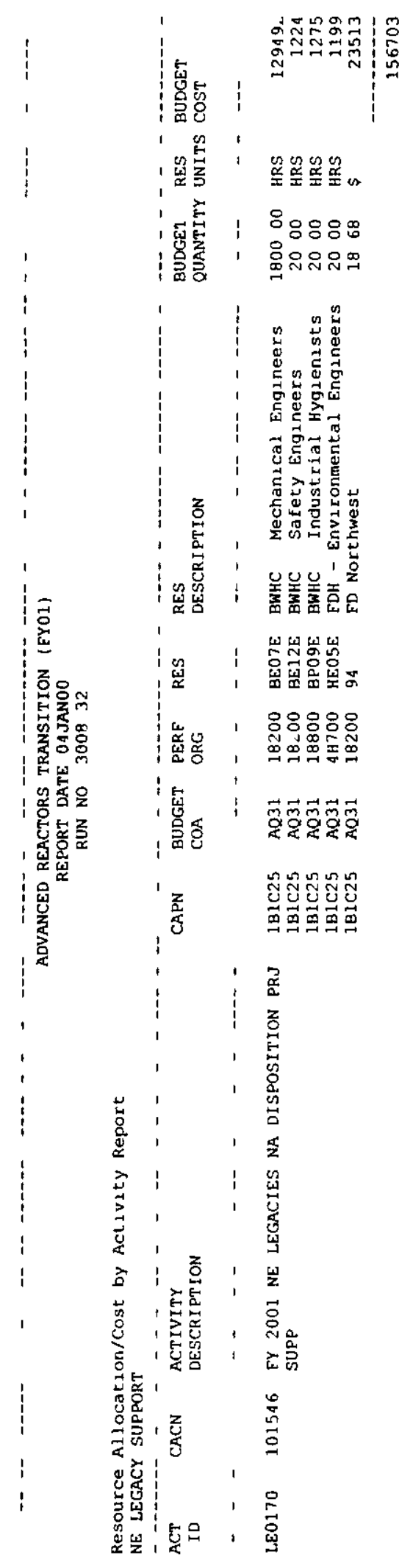




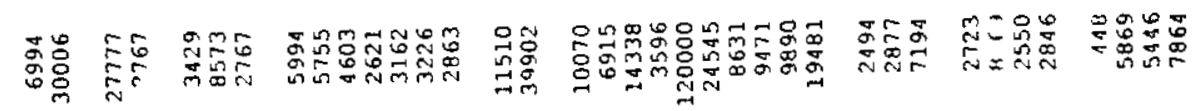

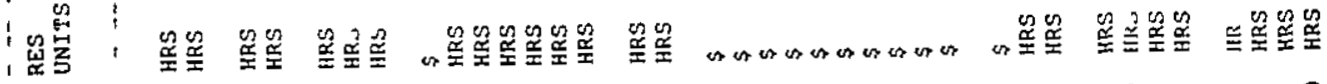

'

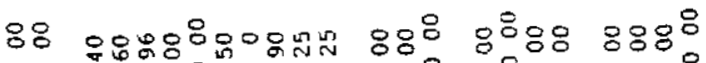

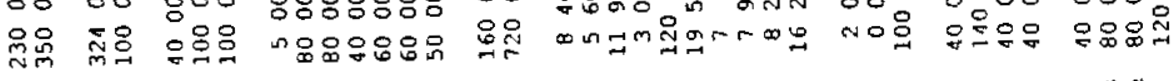

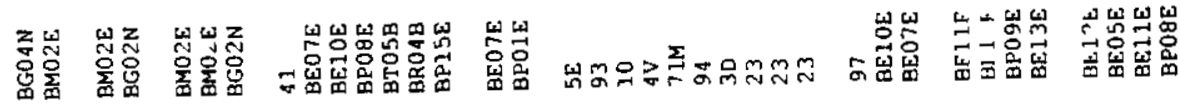

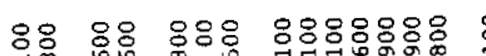

|

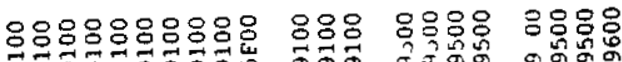




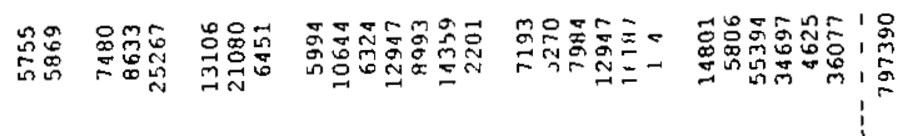

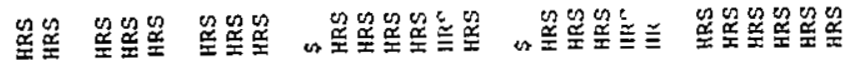

$88.888888888888 .888 \varepsilon_{3} 8.888 \pi$

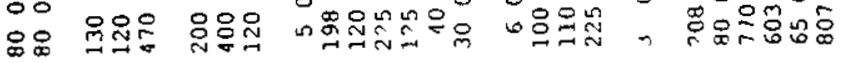

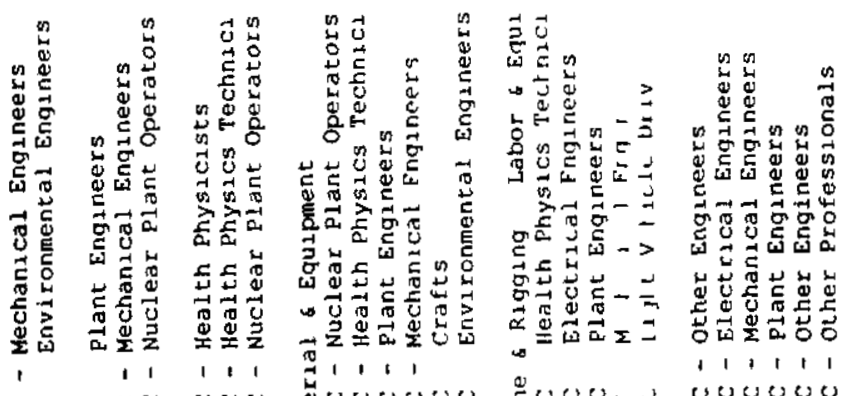

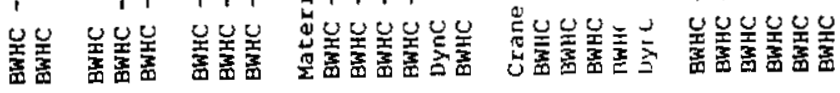

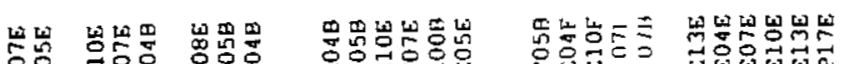

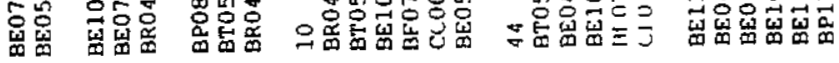

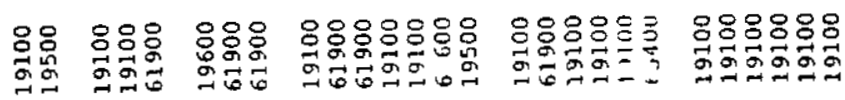

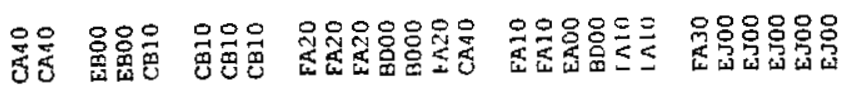

\section{胥范

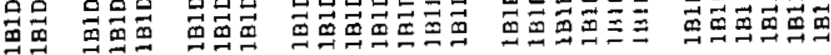

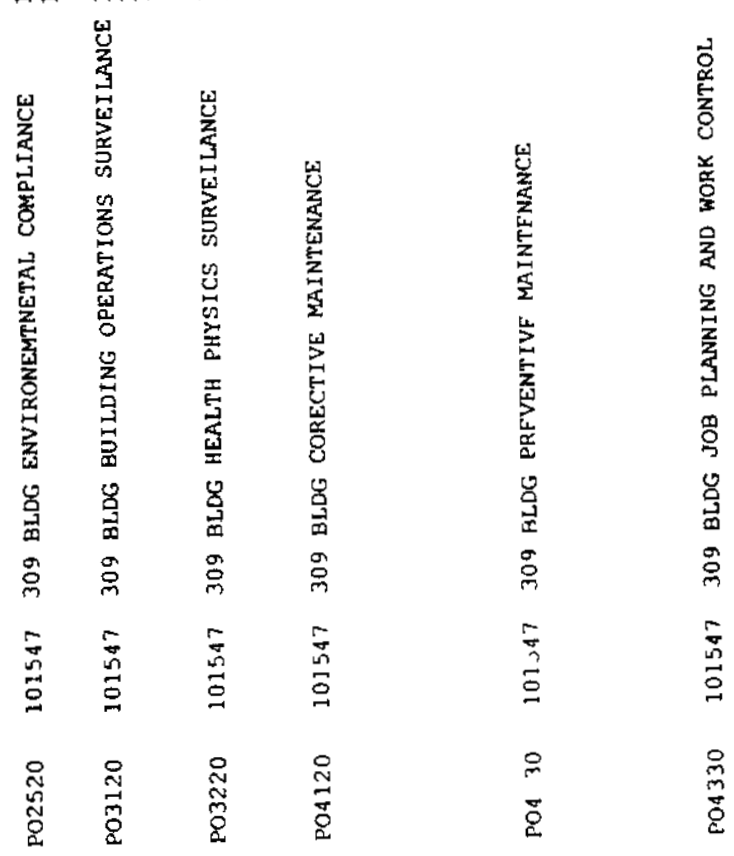




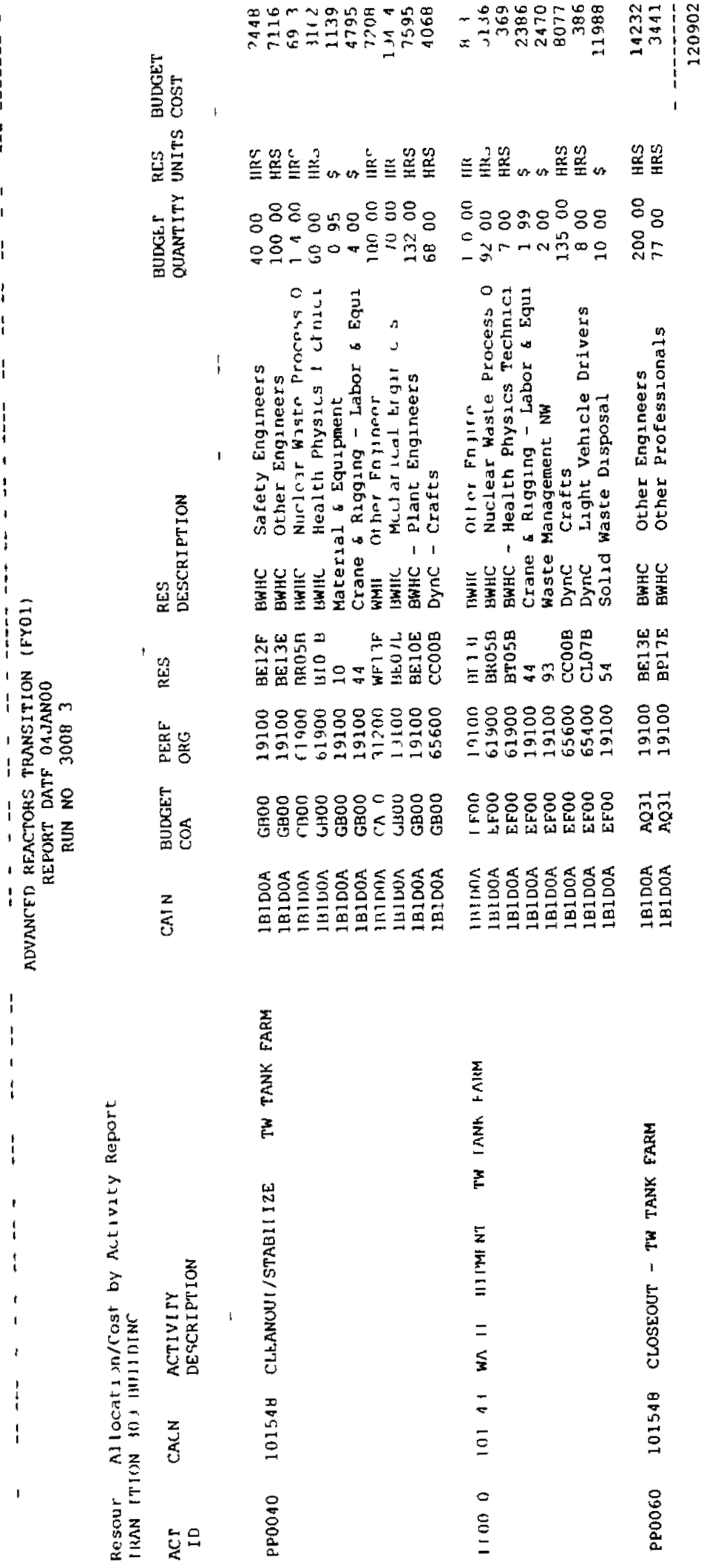




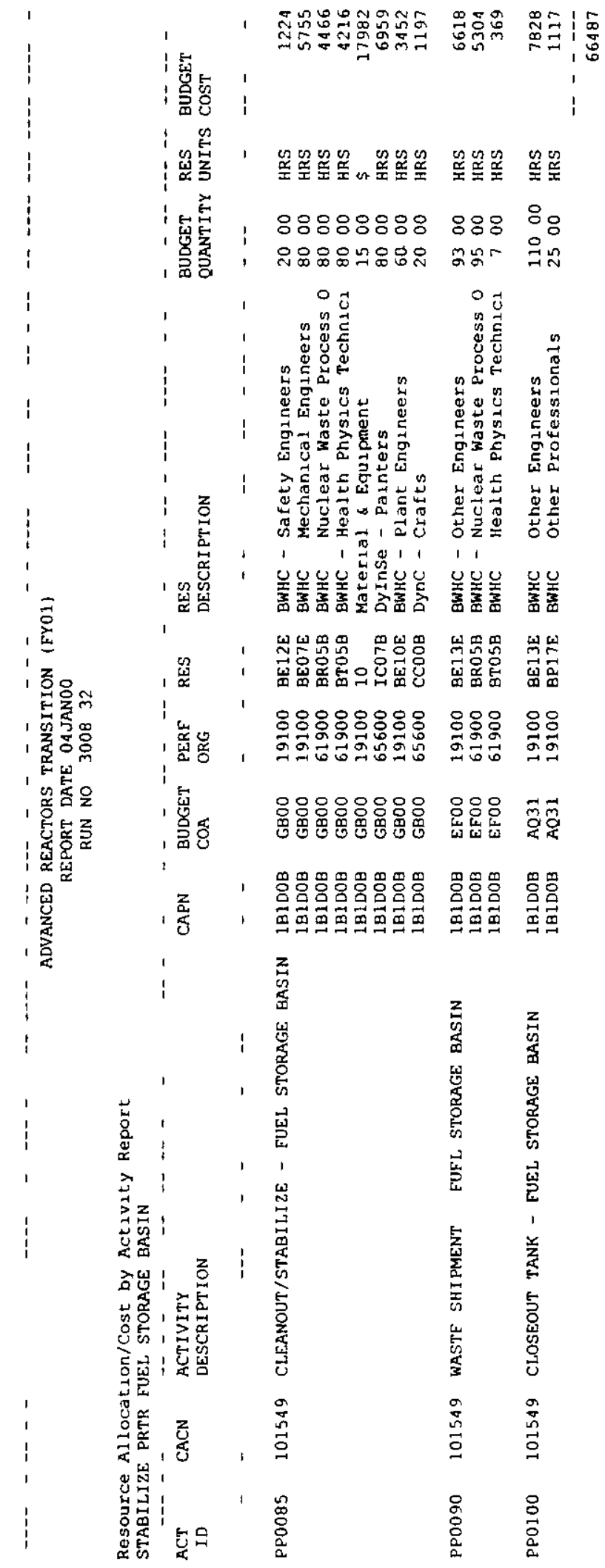




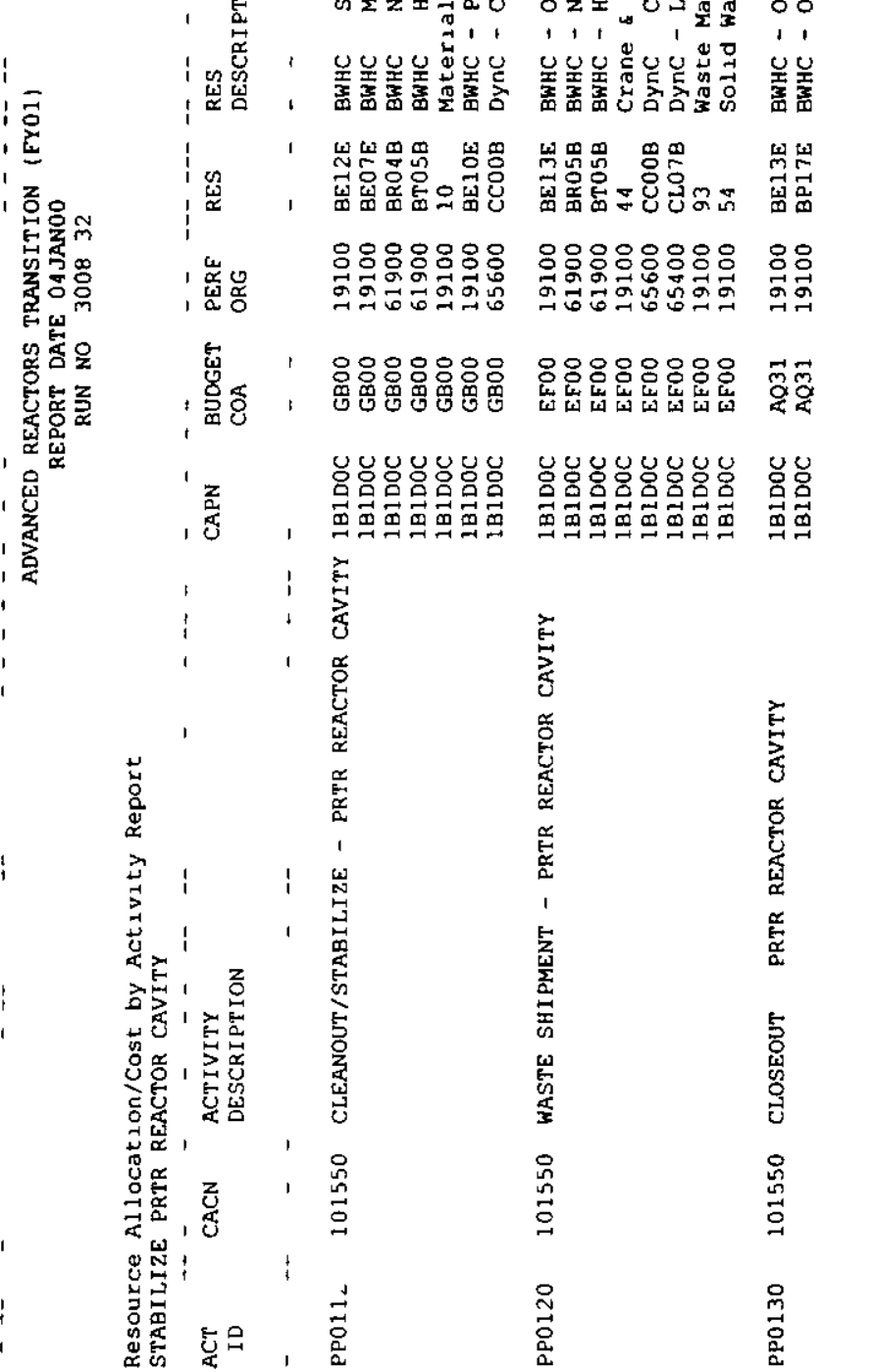




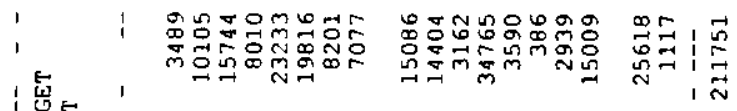

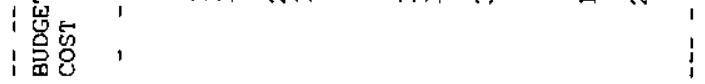

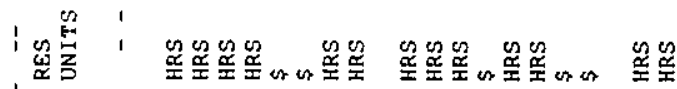
浐

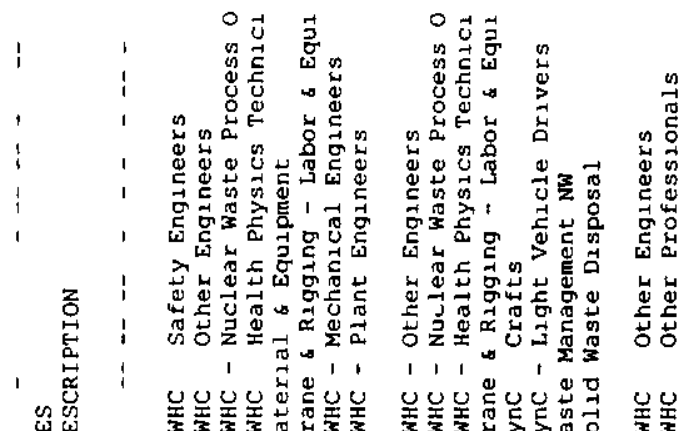

'

$\stackrel{\leftrightarrow}{x}$

i

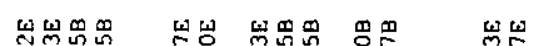

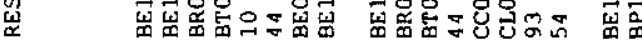

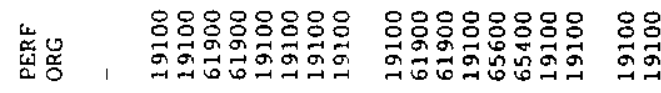

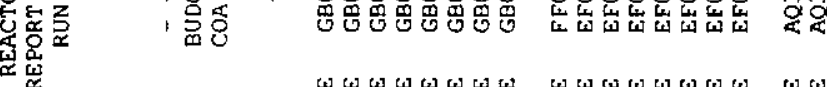

证

,

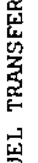

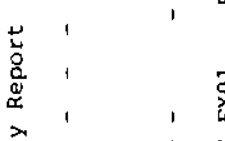

ì

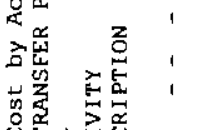

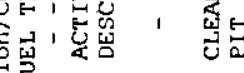

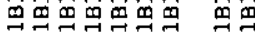

它

焉

(5)

ज्ञ

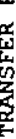

章

岂

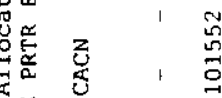

造 ,

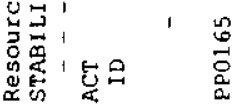

$\begin{array}{ll}0 & \stackrel{0}{0} \\ \stackrel{0}{0} & \stackrel{0}{0}\end{array}$ 


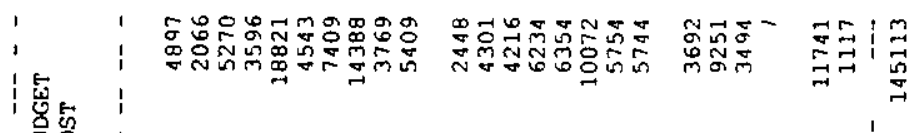

, 鬲宫

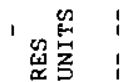

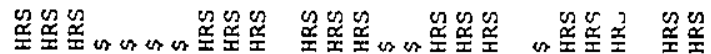

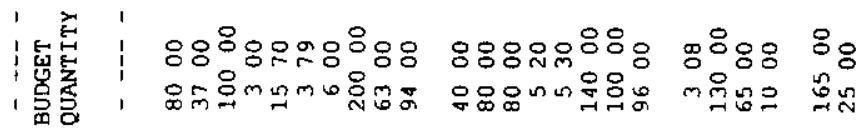

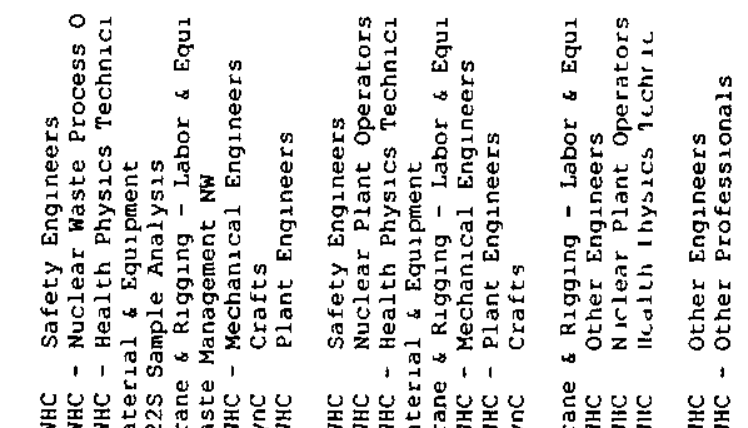

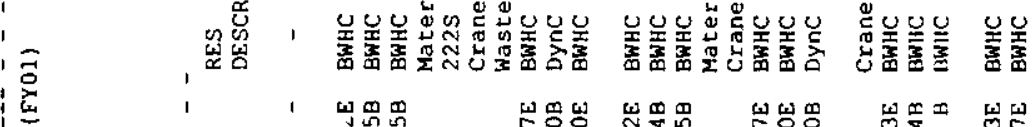

'

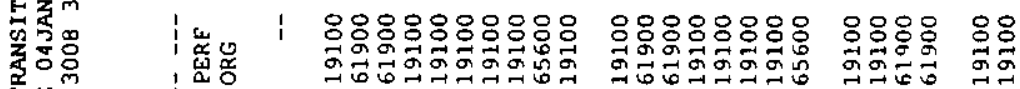

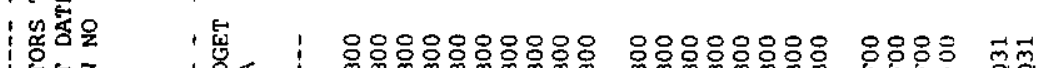

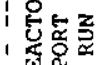

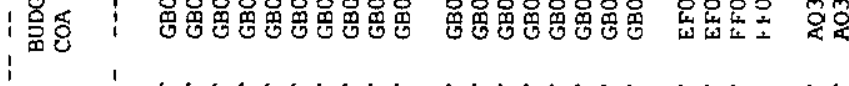

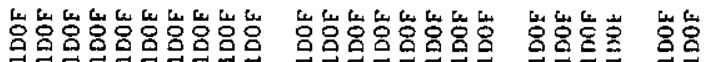

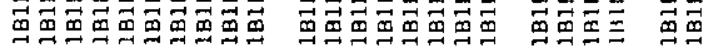

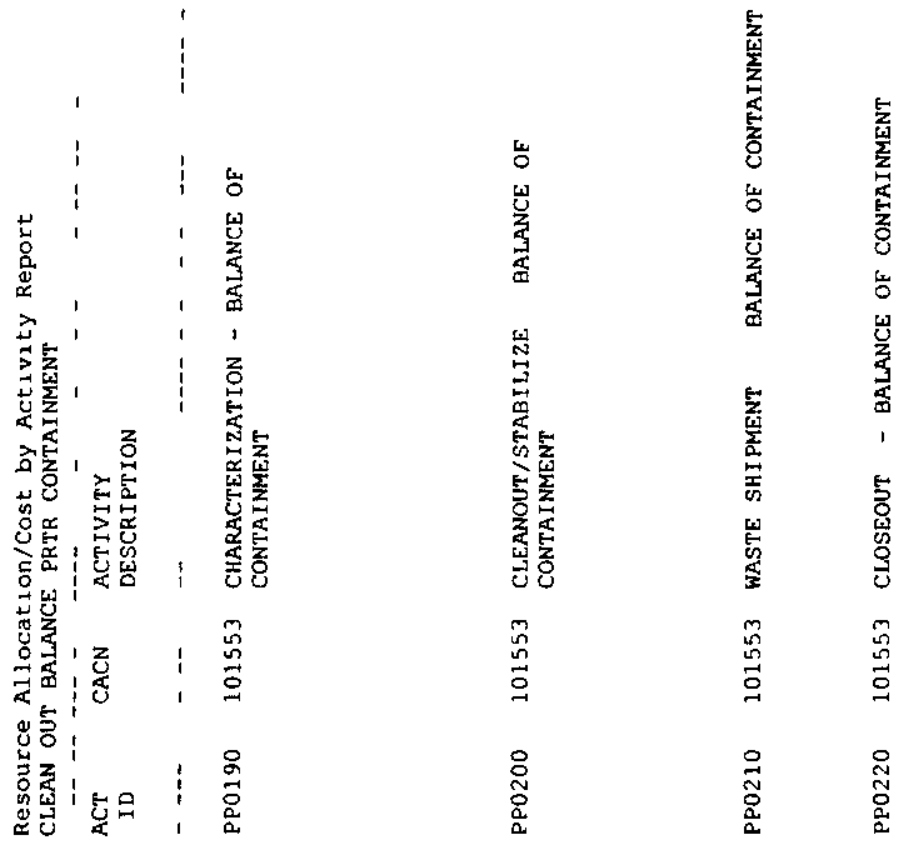


HNF SD-FF SSP-050

Rev 8 Page 130

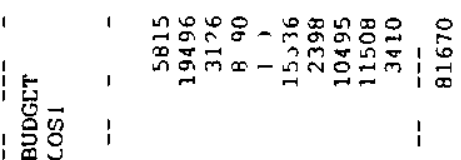

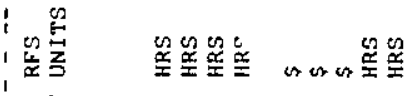

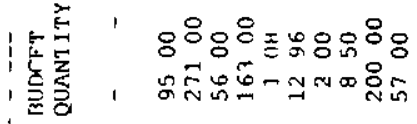

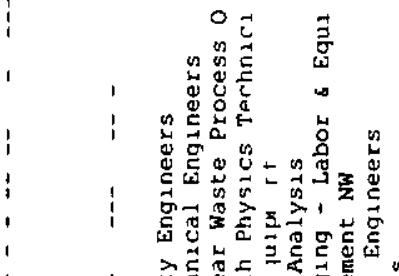

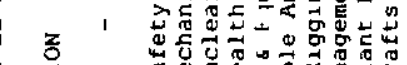

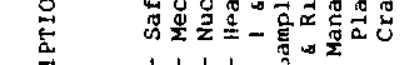

妾

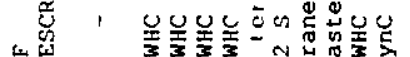

$\sum$ NU⿺廴

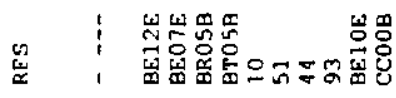

' ᄂ

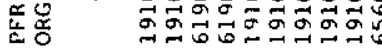

' 党

z

, 点

1

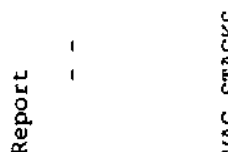

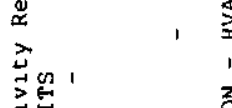

氙

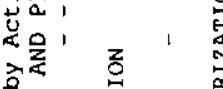

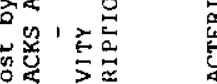

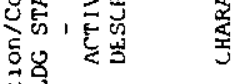

娄

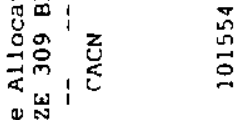

諝: 


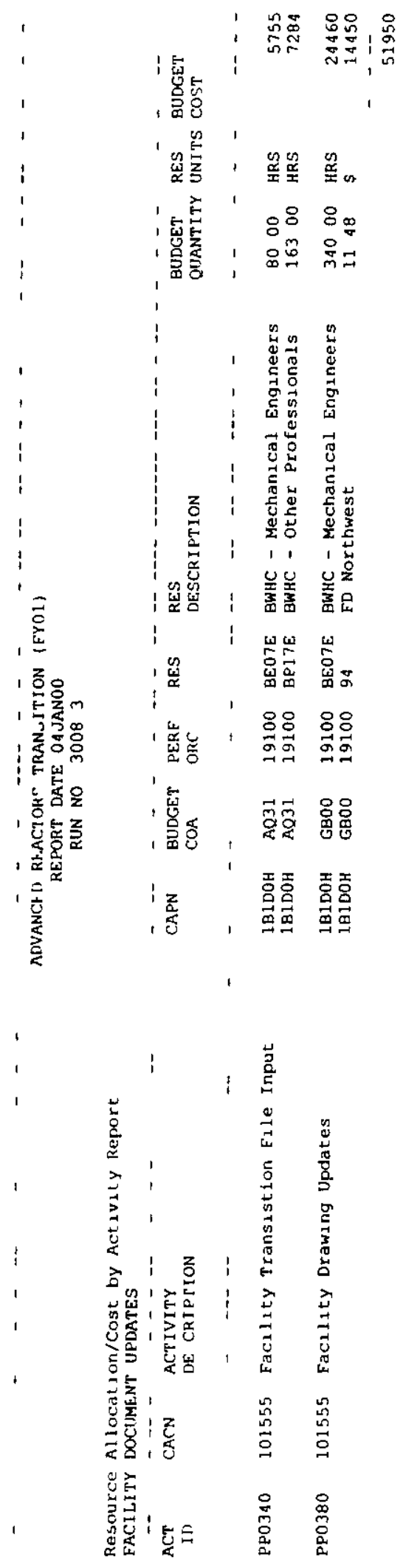




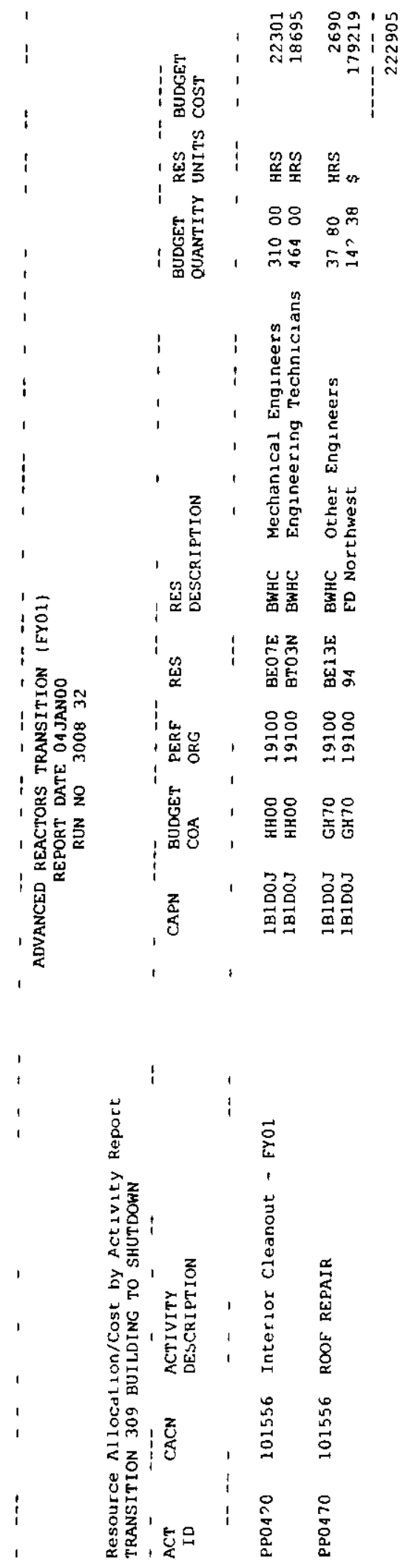


HNF SD-FF SSP-050

Rev 8 Page 133

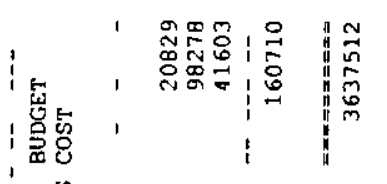

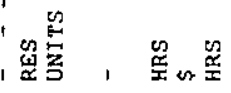

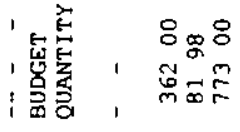

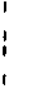

1

包

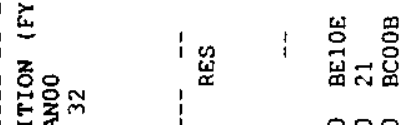

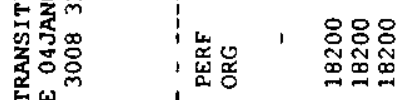

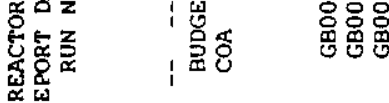

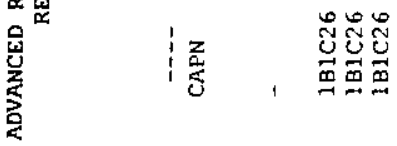

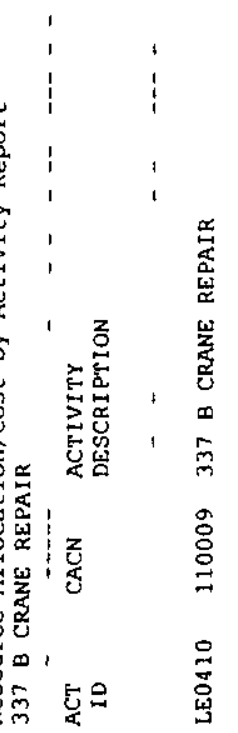


HNF-SD-FF-SSP-050

Rev 8 Page 134

THIS CHANGE INTENTIONALLY BLANK 


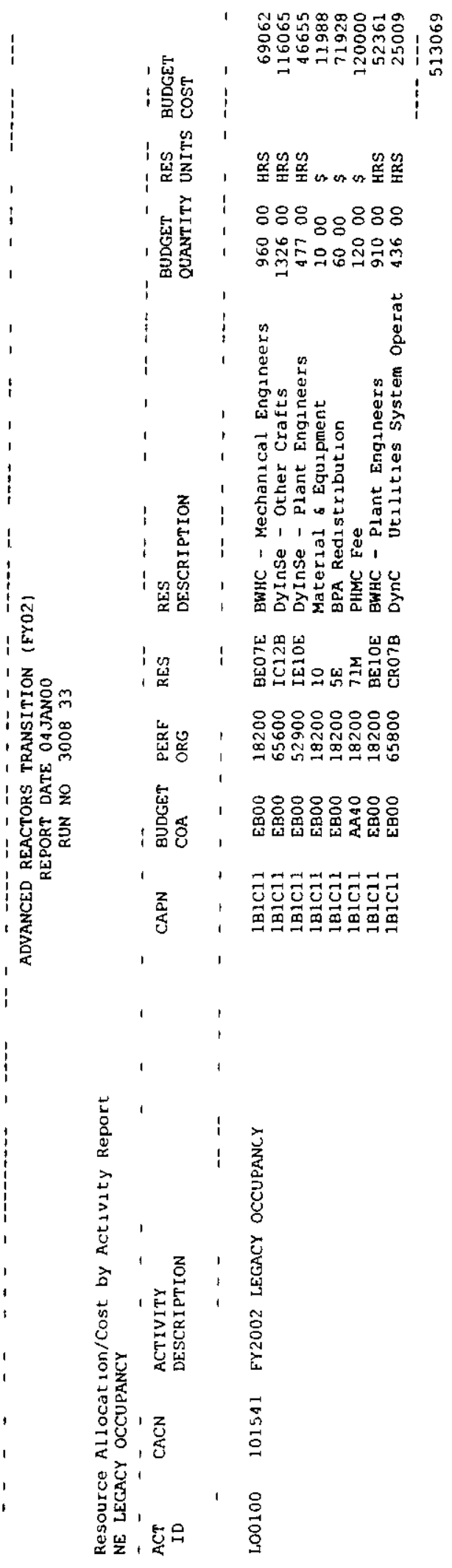


HNF-SD FF SSP 050

Rev 8 Page 136

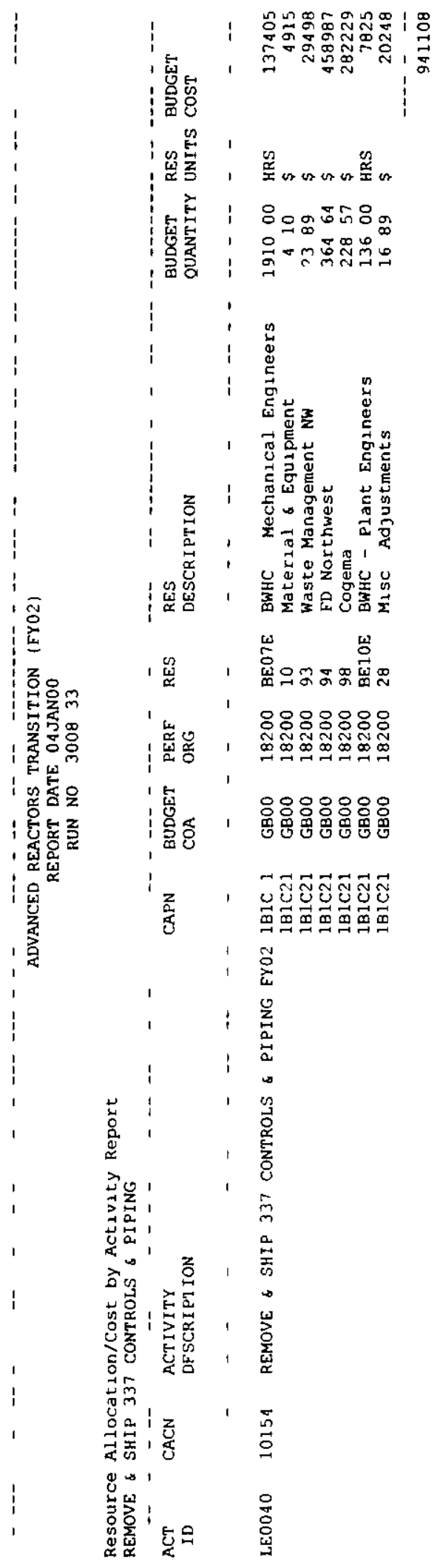




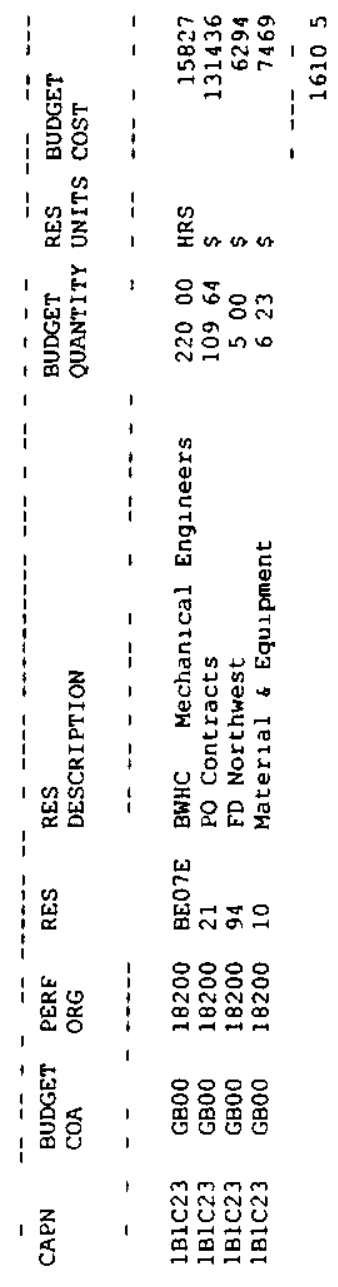




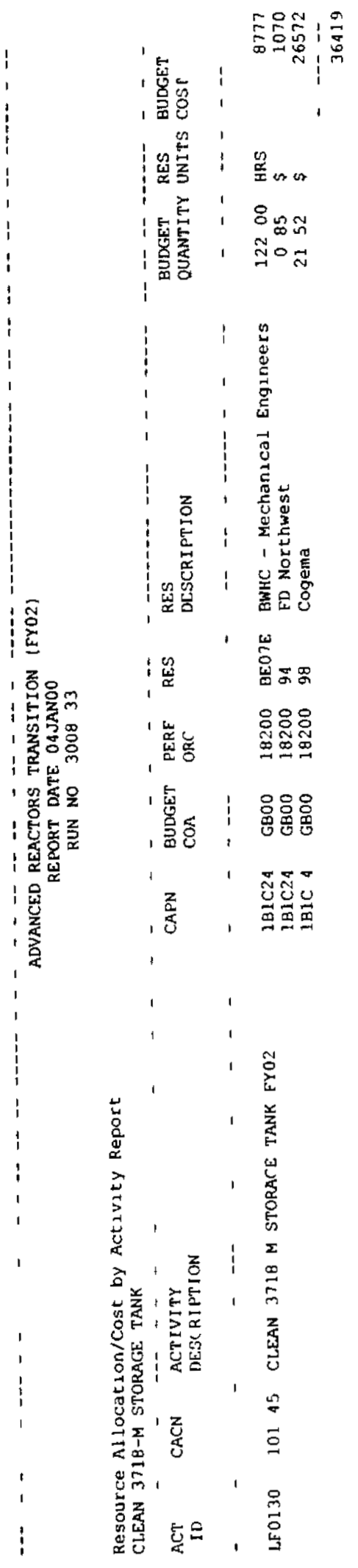




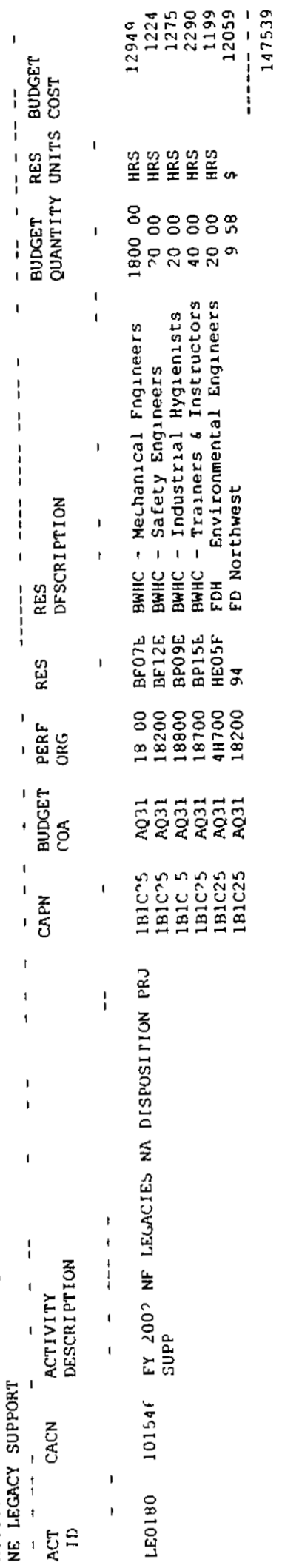




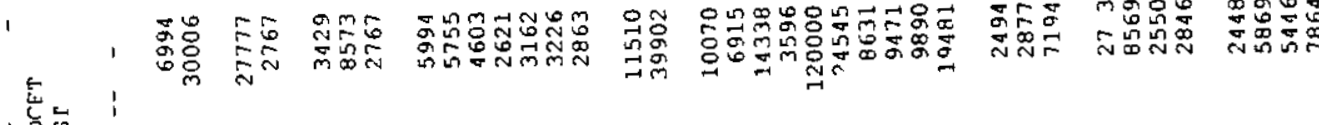
经参，

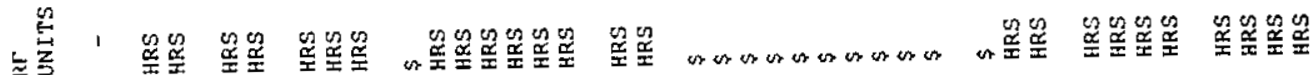

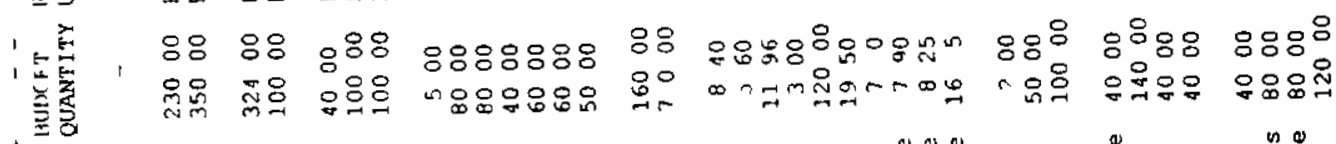

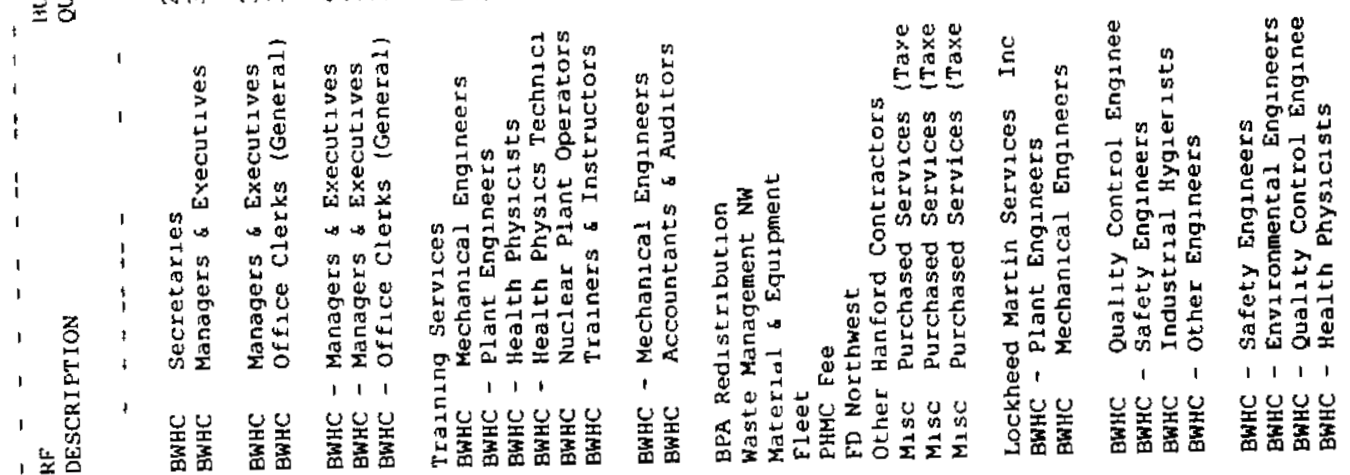

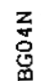

蓄

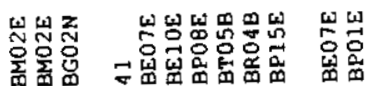

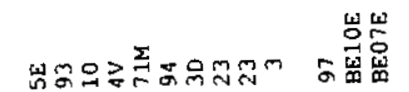

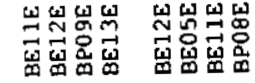

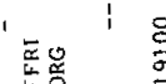

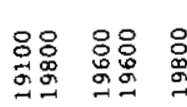

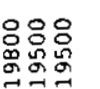

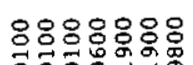

骂骨

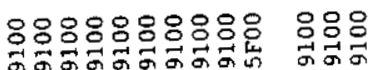

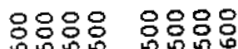

'

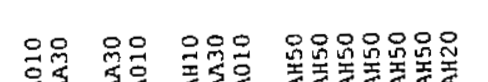

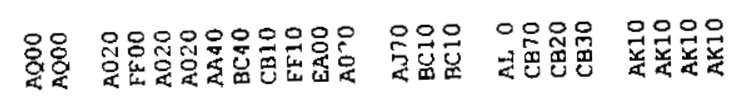

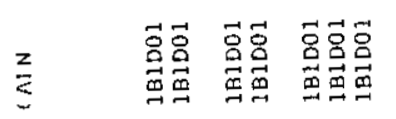

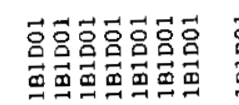

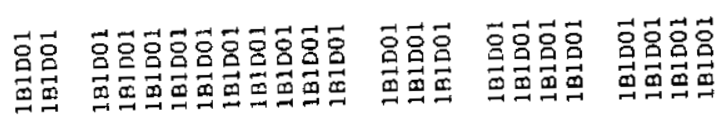

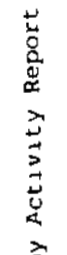

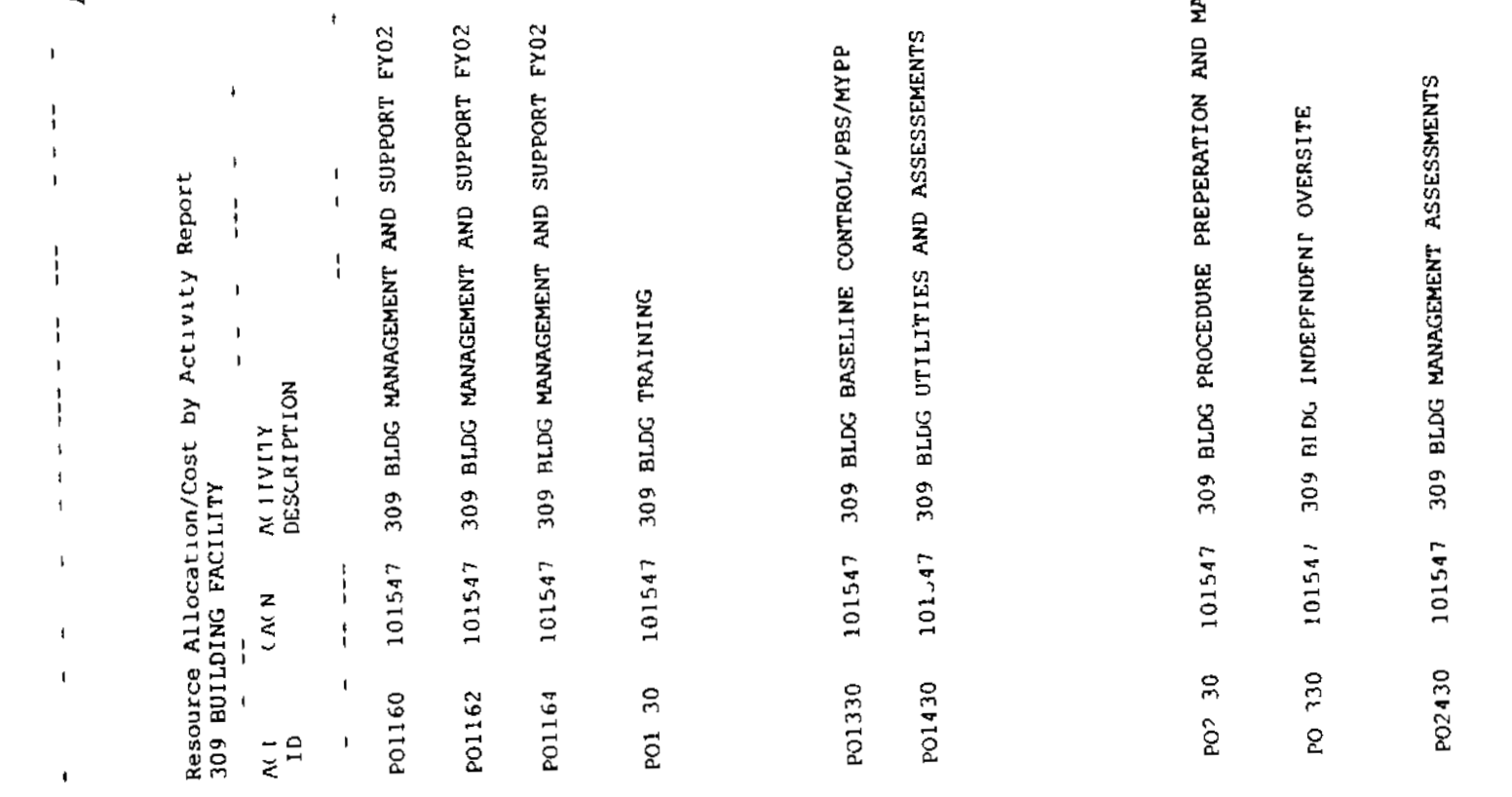

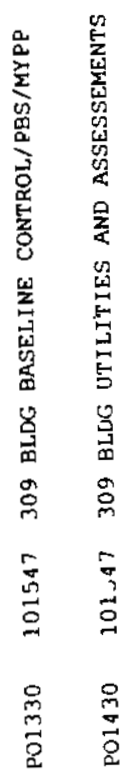

蓄 


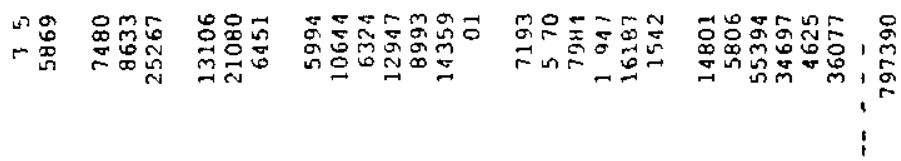

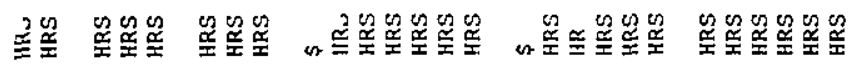

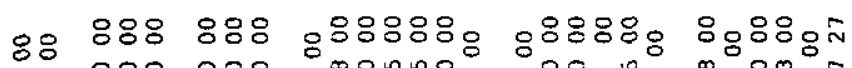

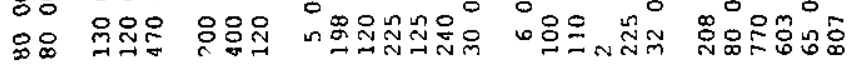

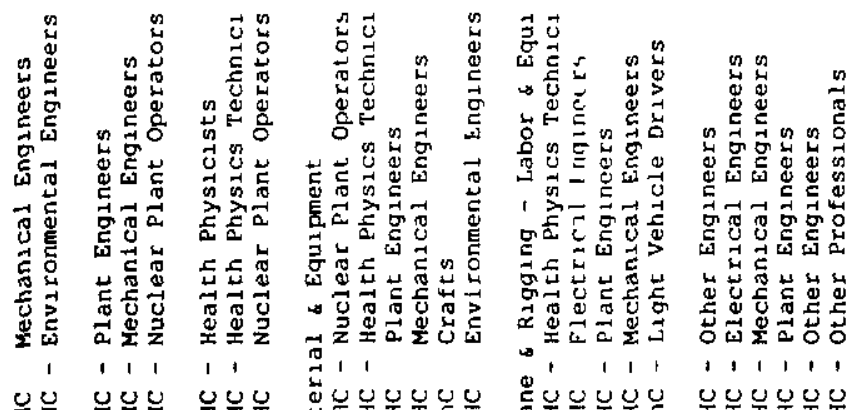

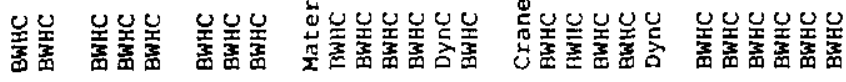

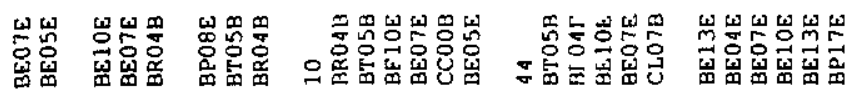

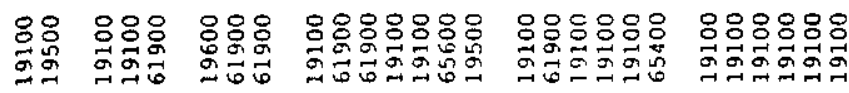

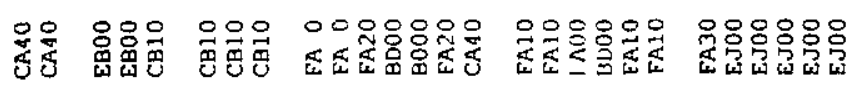

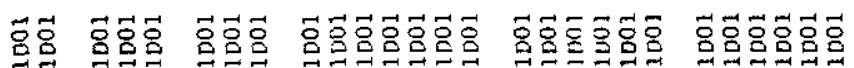

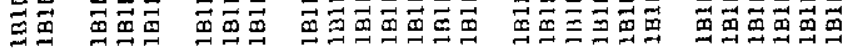

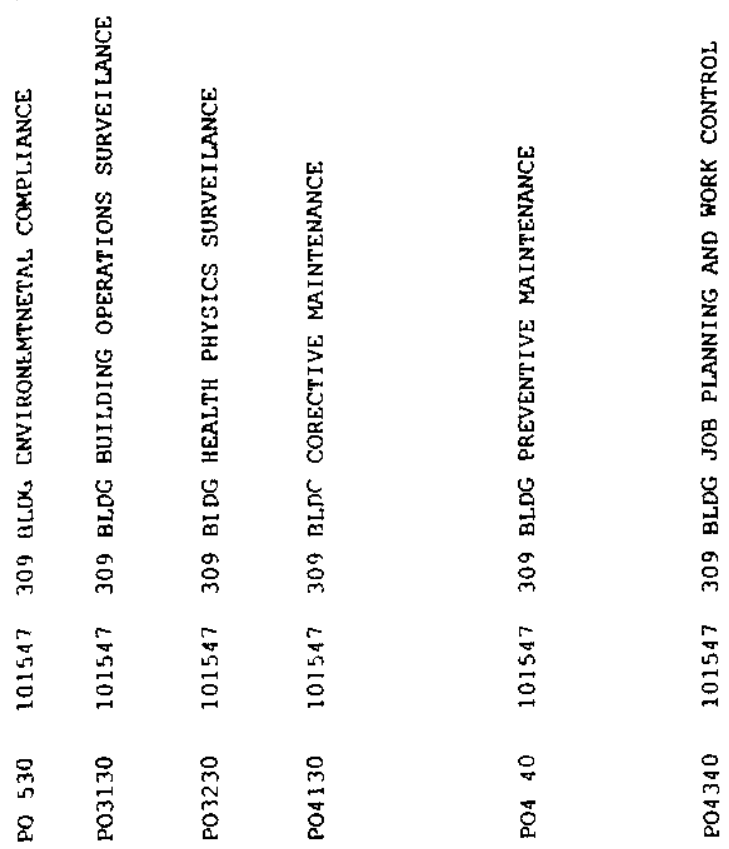




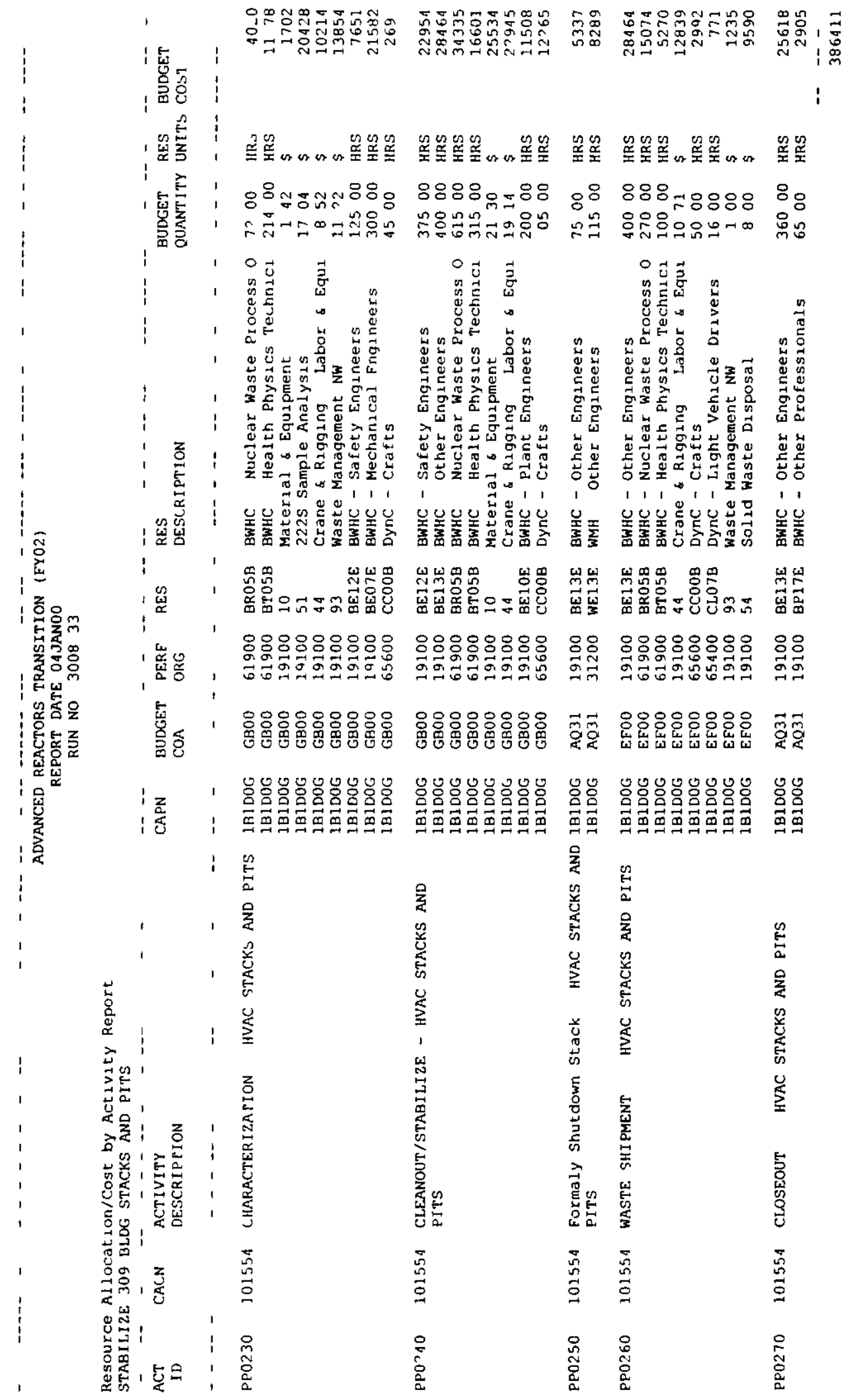




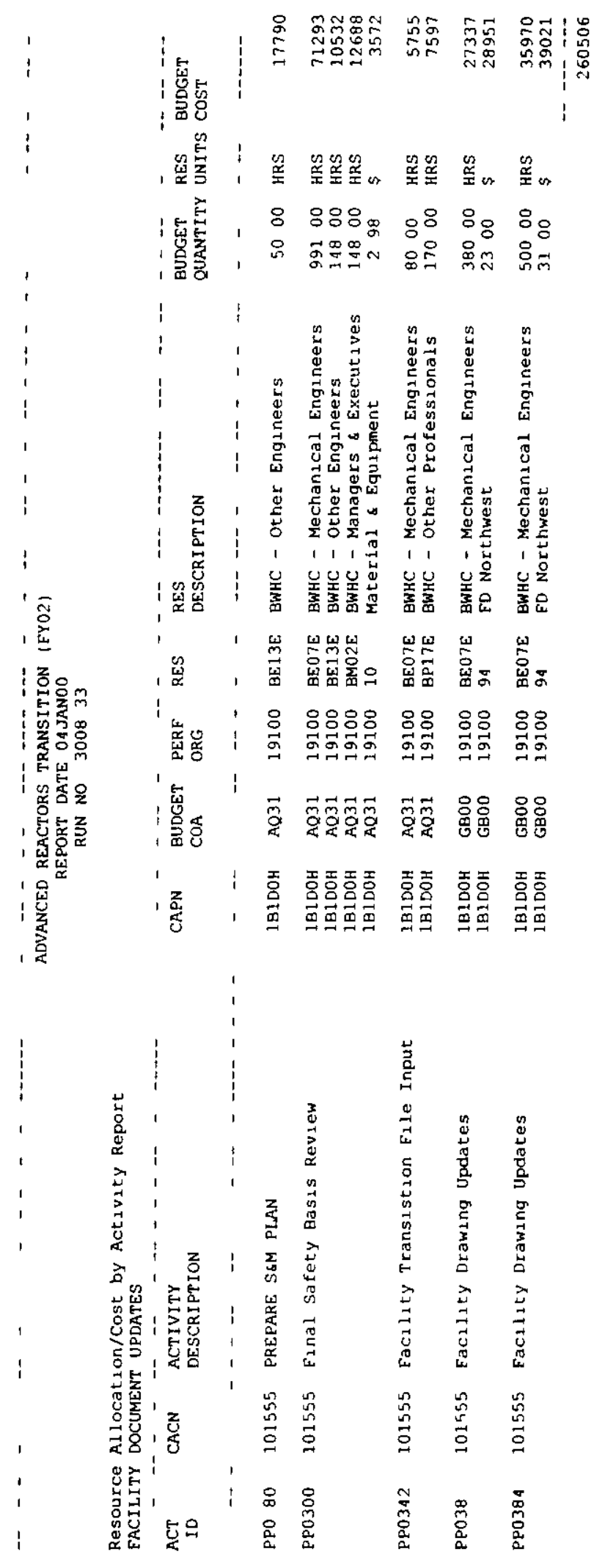



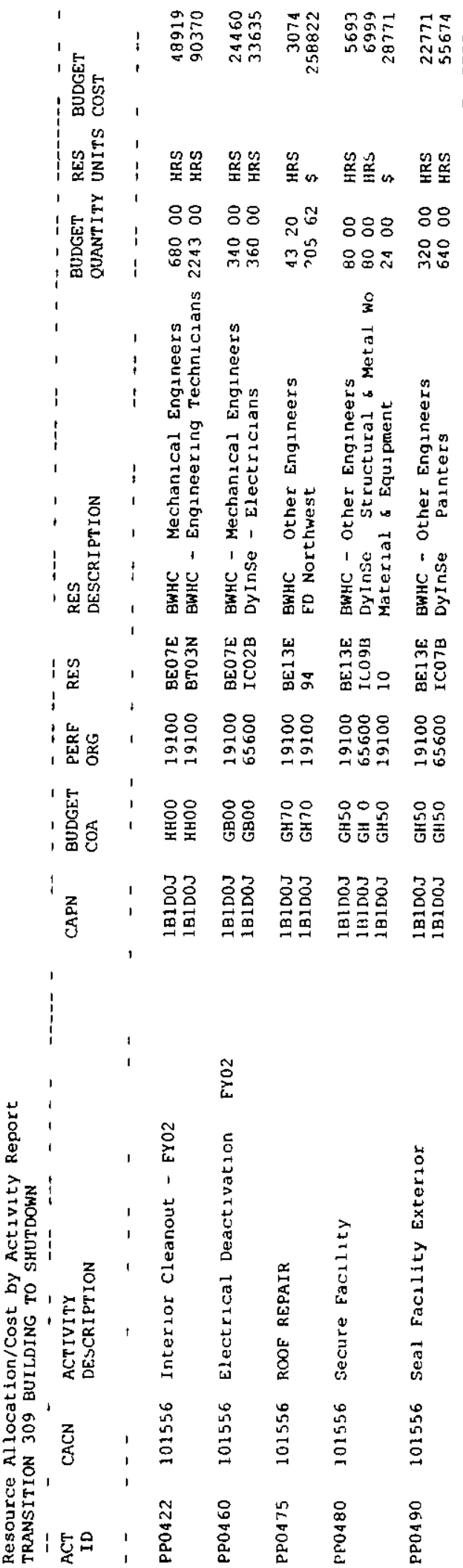


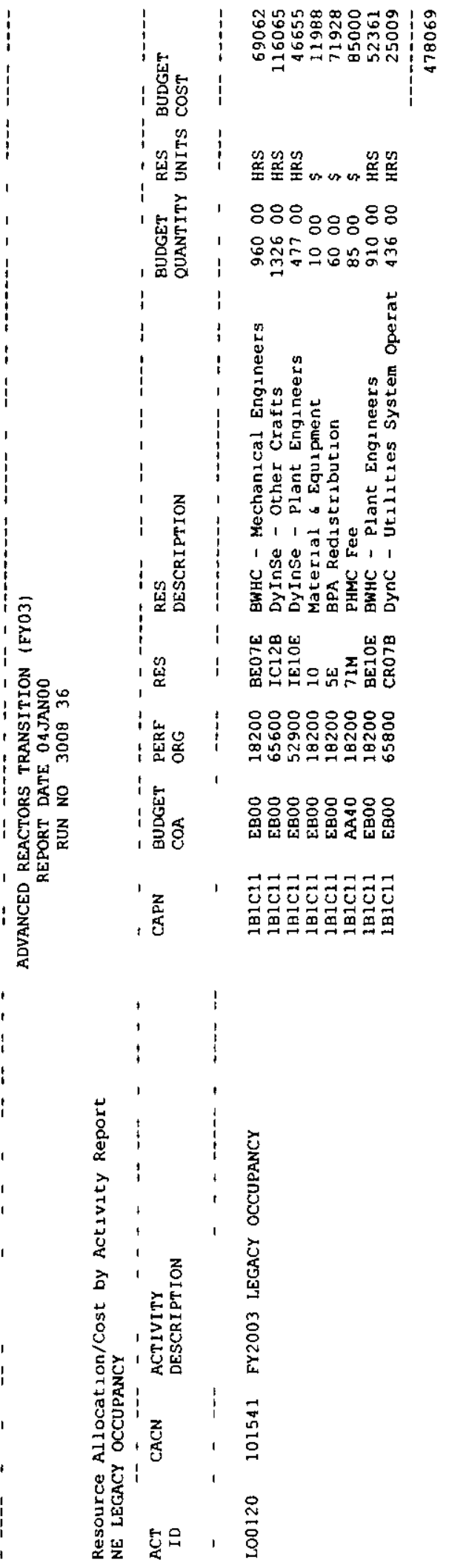




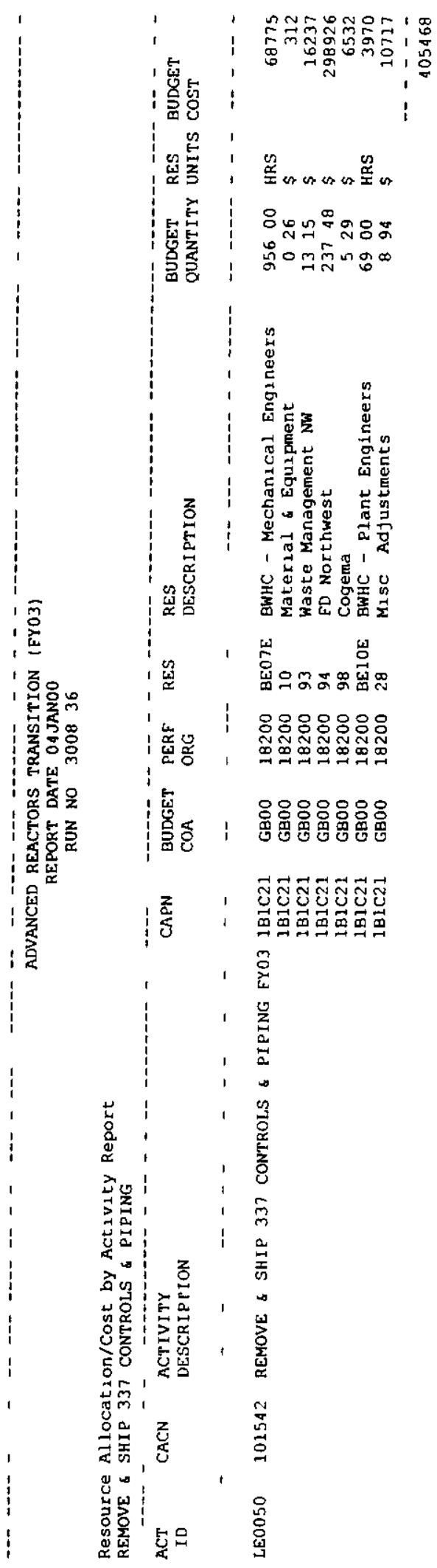




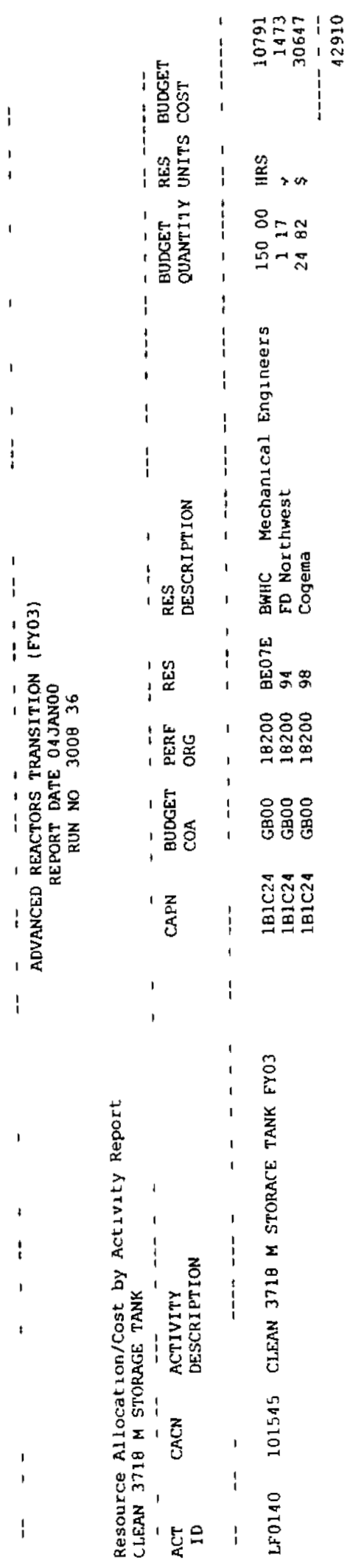


HNF-SD-FF SSP 050

Rev 8 Page 148

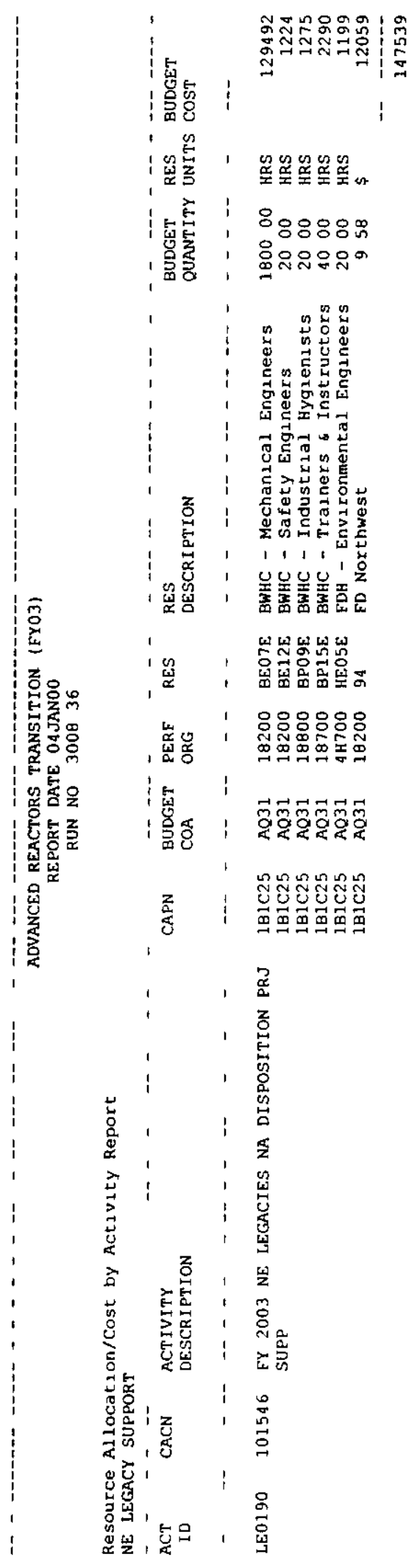




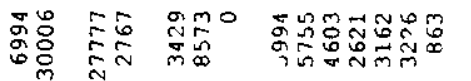

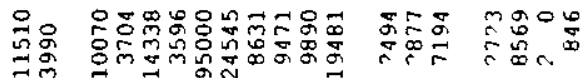

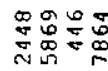

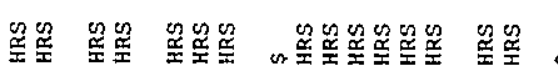

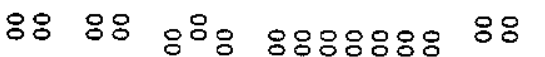

웅으

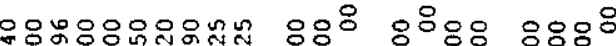

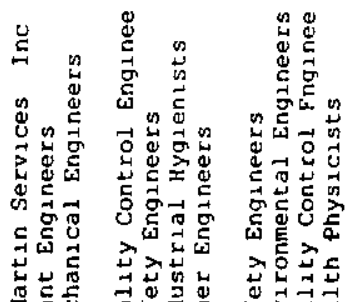

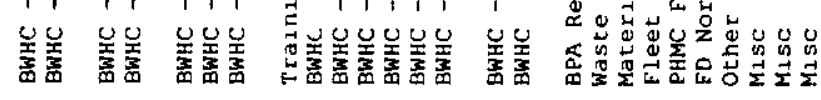

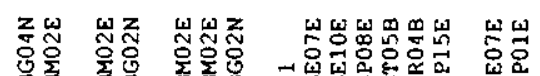

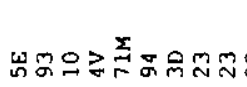

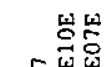

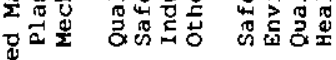

造

1,1

' ‘岕: :

: :

응

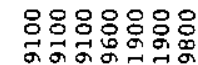

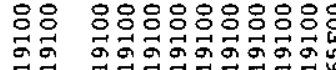

웅융

नَّ

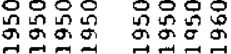

毫量

年

웅

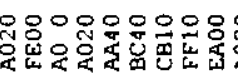

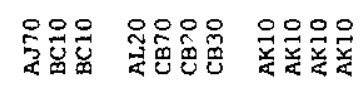

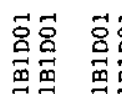

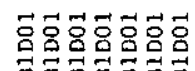

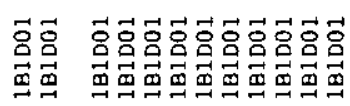

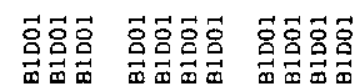

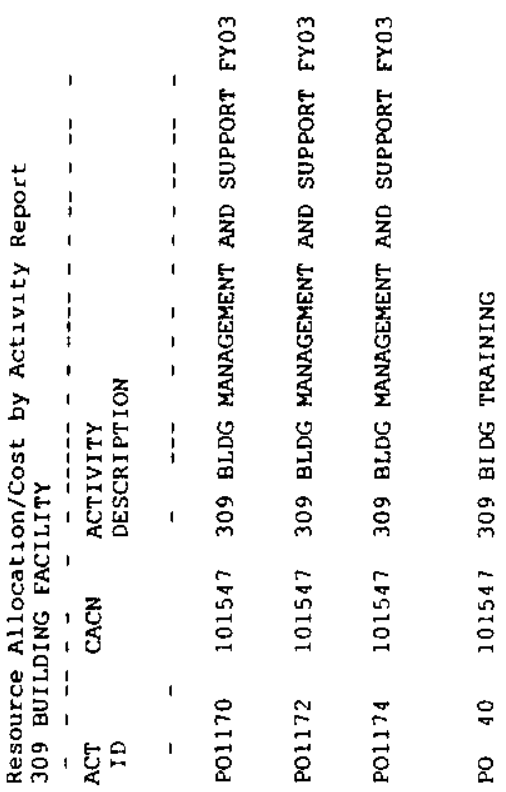

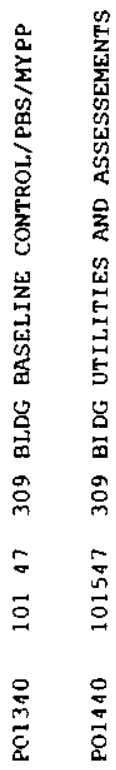

党

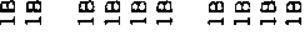




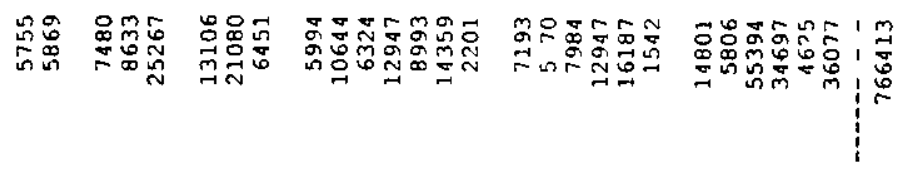

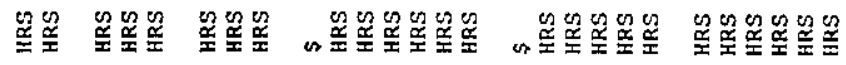

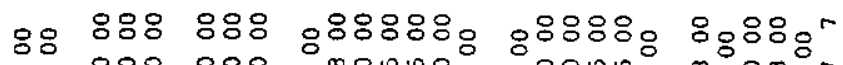

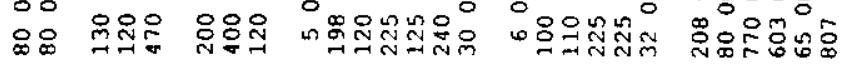
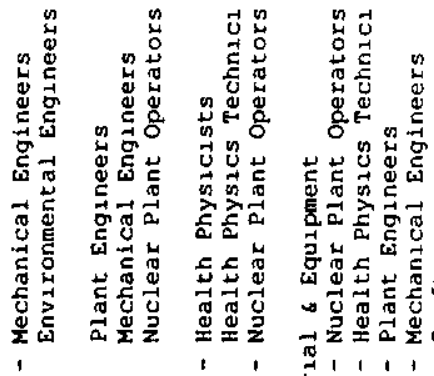

艺导密宦

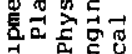

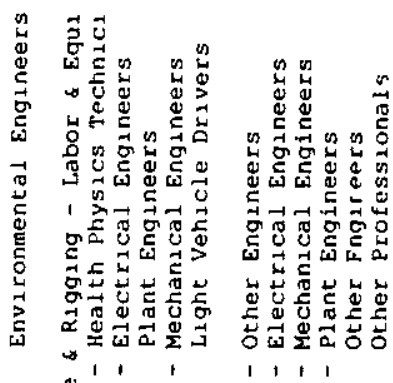

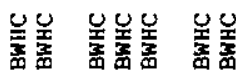

(1)

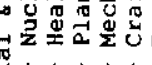

111

$\begin{array}{llll}1 & 1 & 1\end{array}$

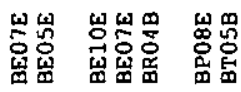

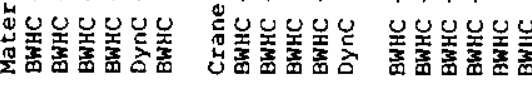

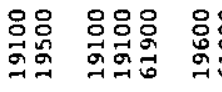

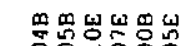

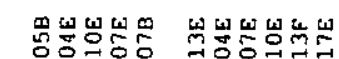

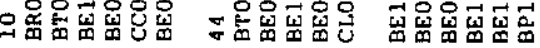

ป.

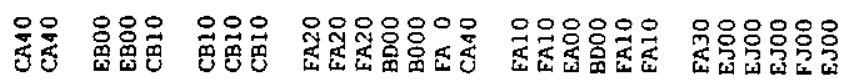

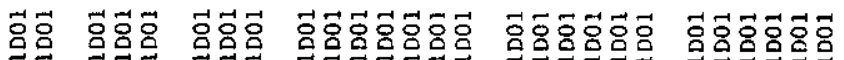

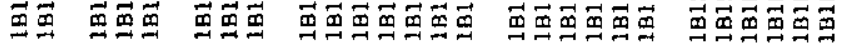

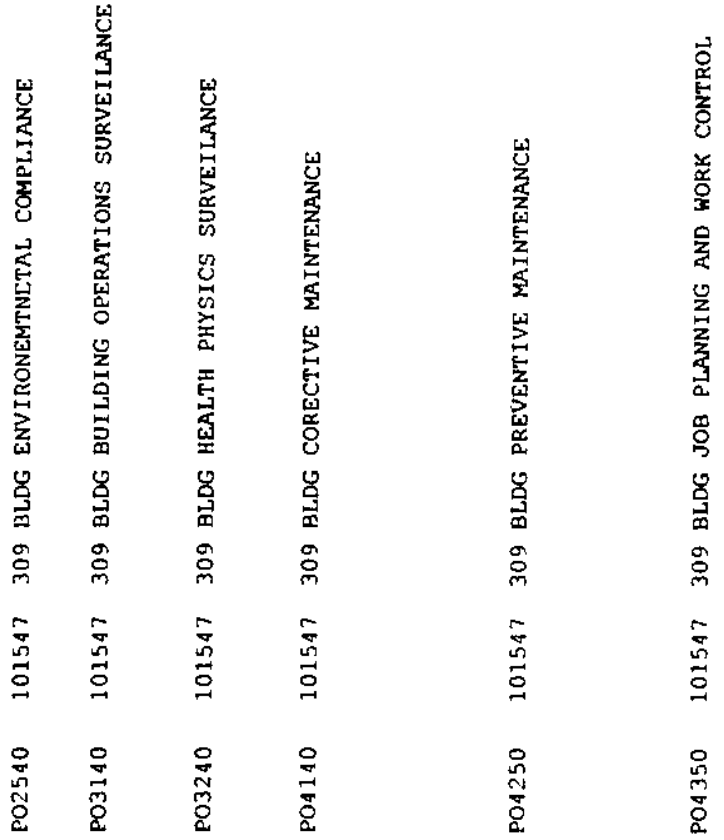




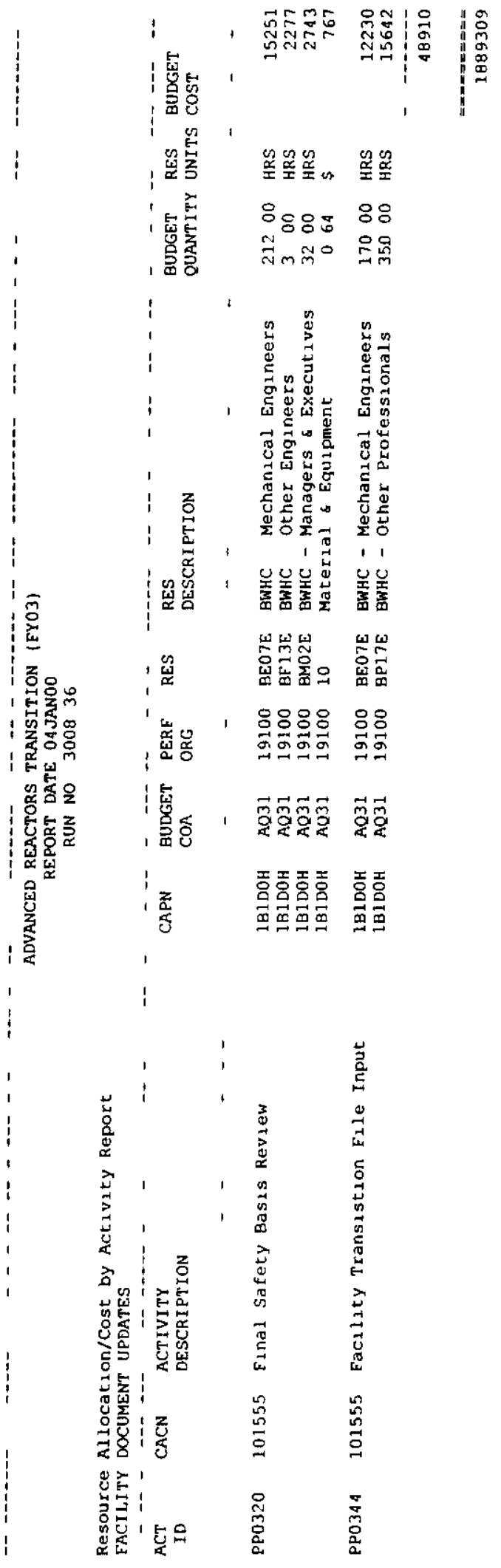


HNF SD FF-SSP 050

Rev 8 Page 152

THIS CHANGE INTENTIONALLY BLANK 
HNF SD-FF SSP-050

Rev 8 Page 153

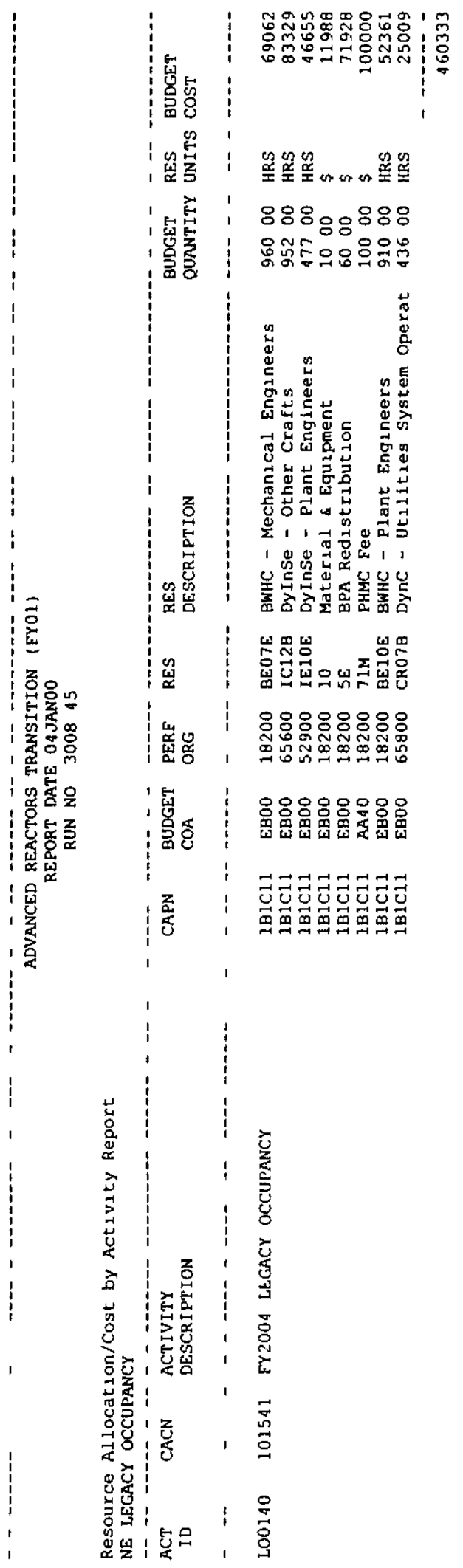




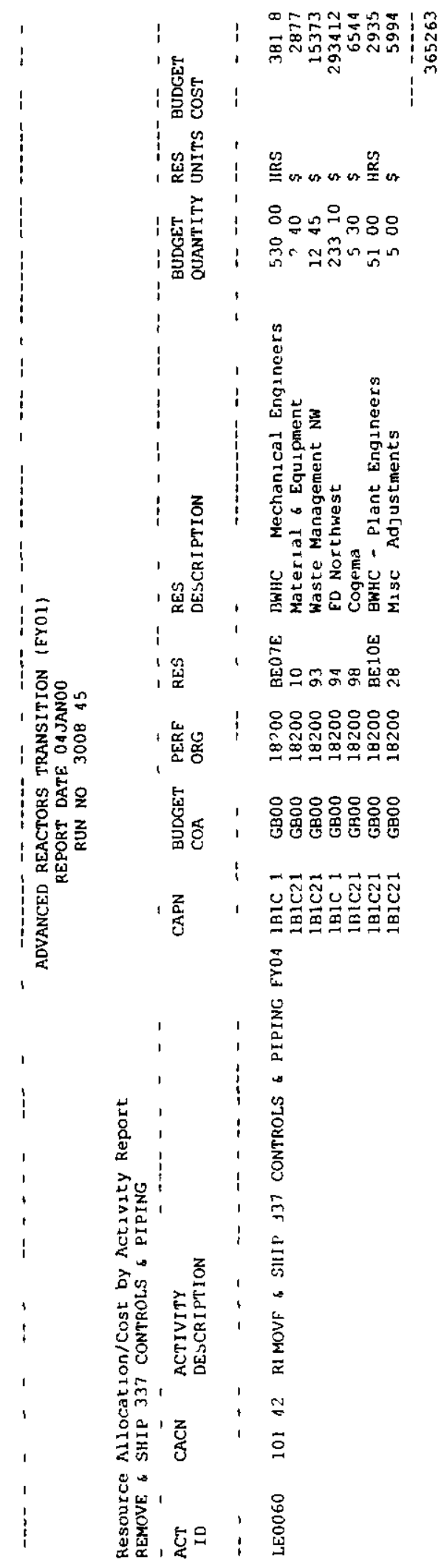




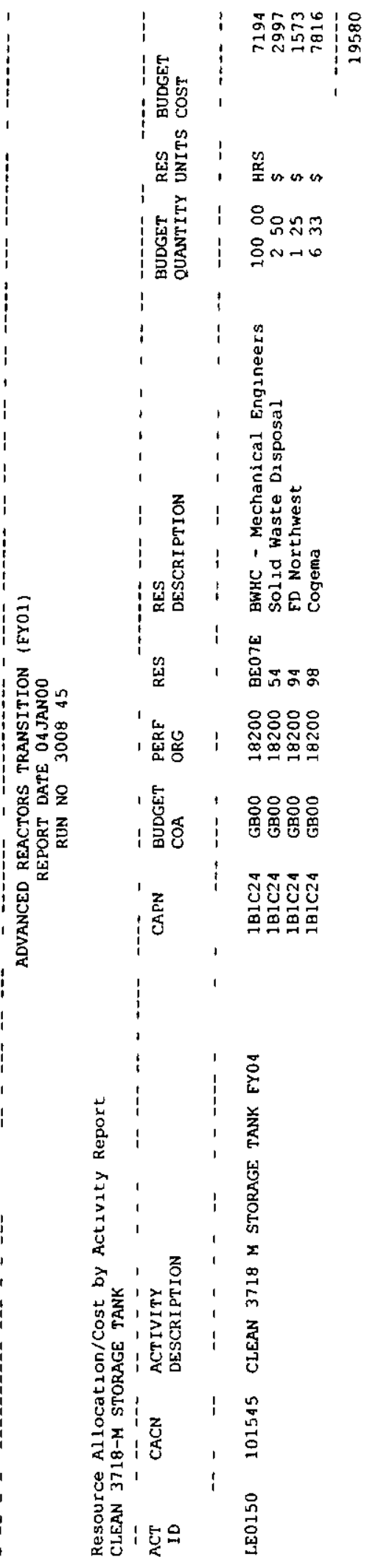


HNF-SD FF-SSP-050

Rev 8 Page 156

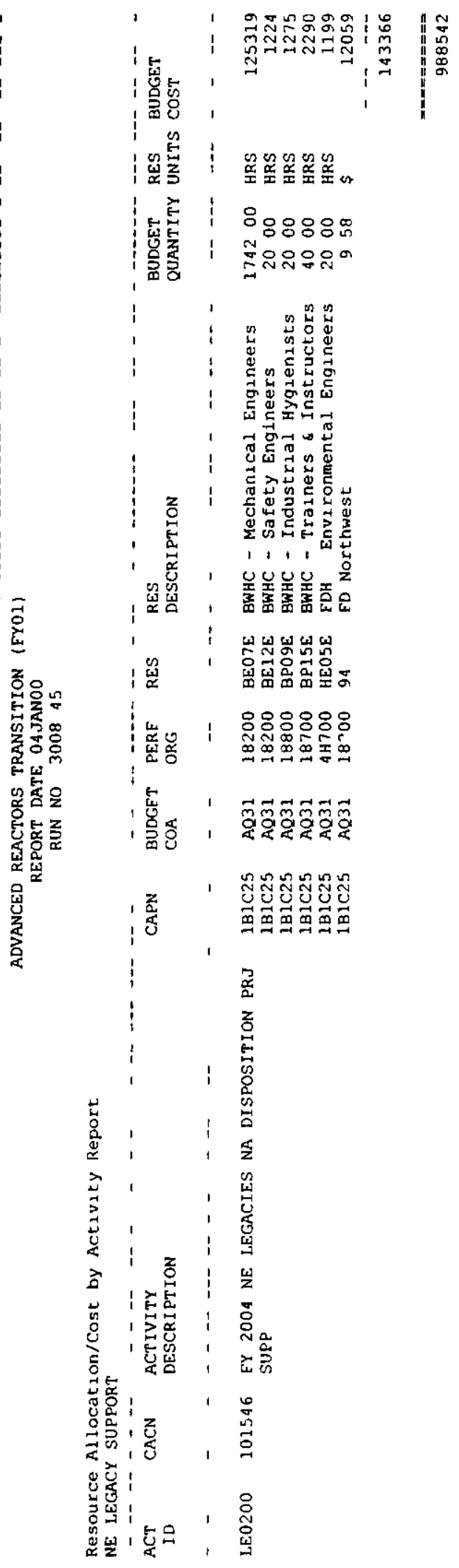




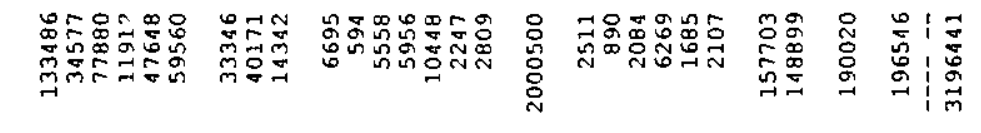

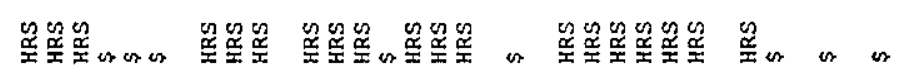

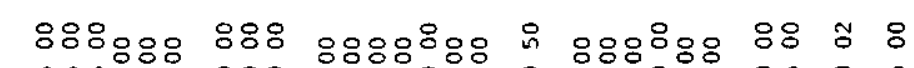

嵌

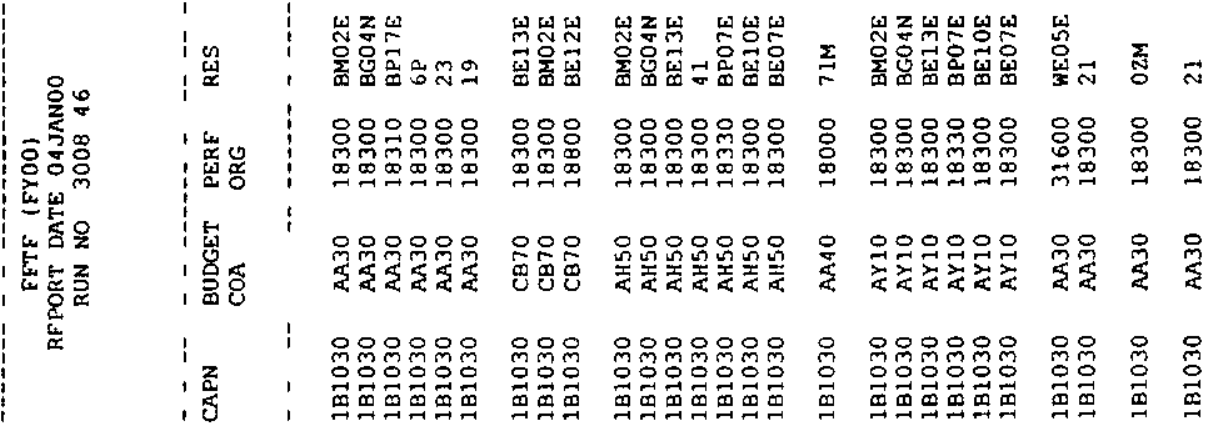

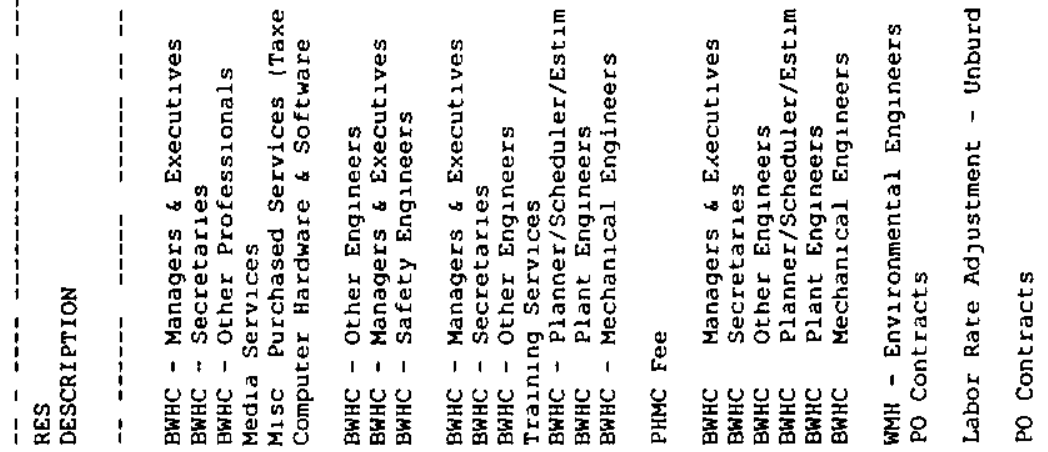

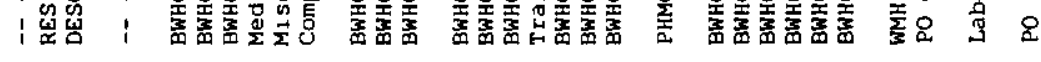

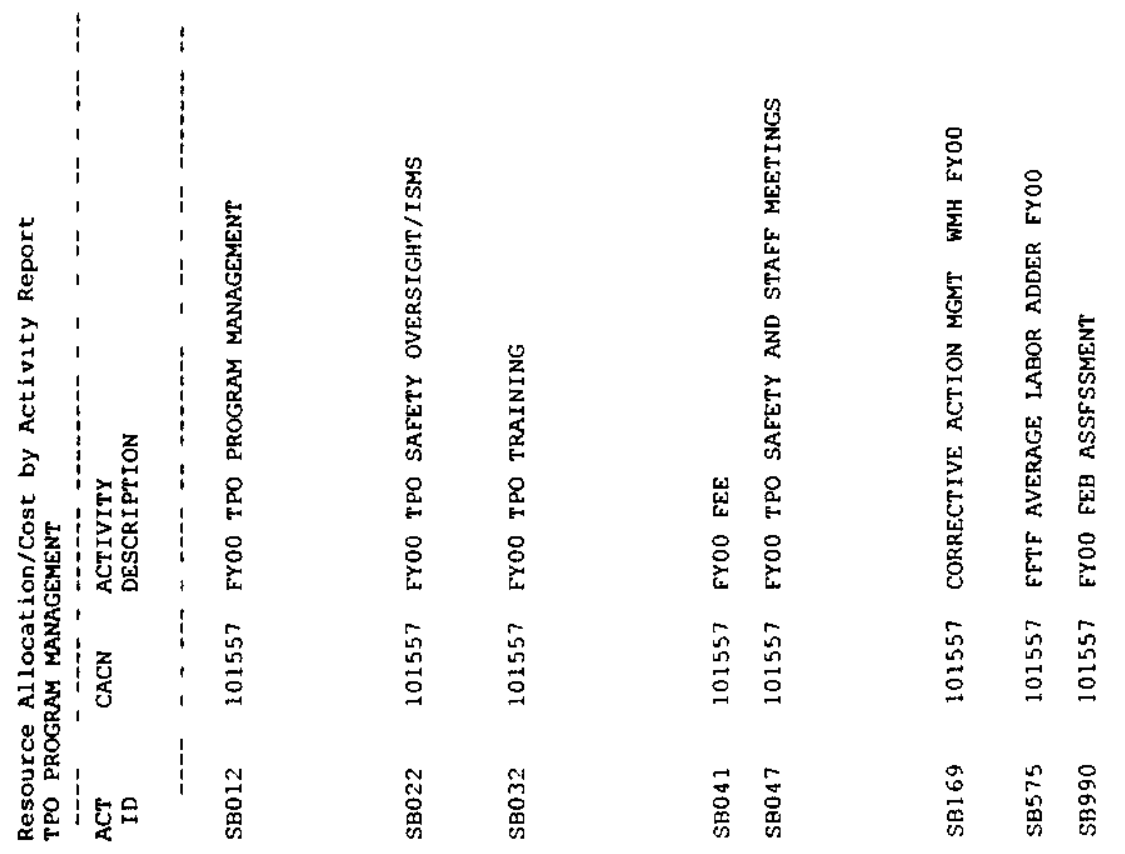




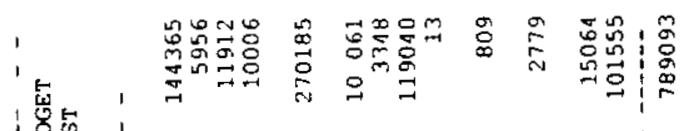

通点

:

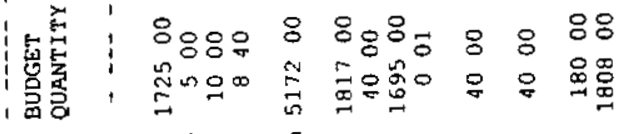

1 E

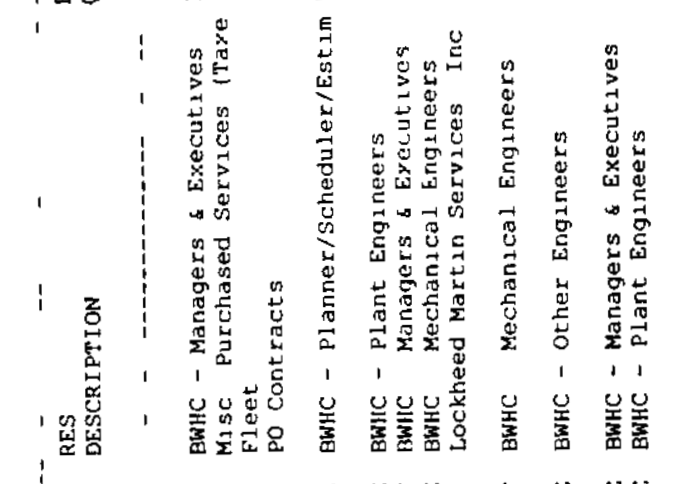

i 1

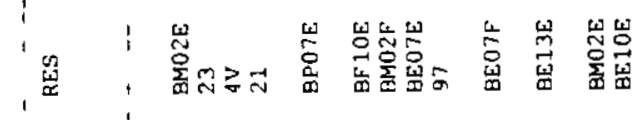

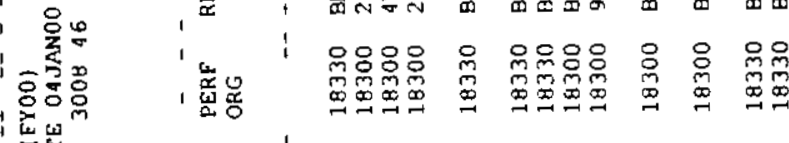

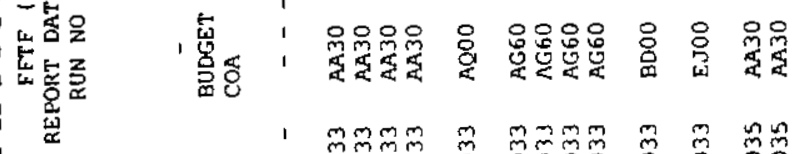

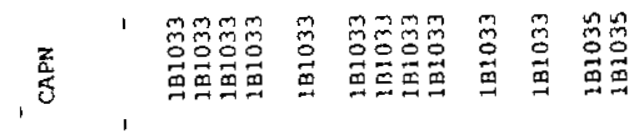

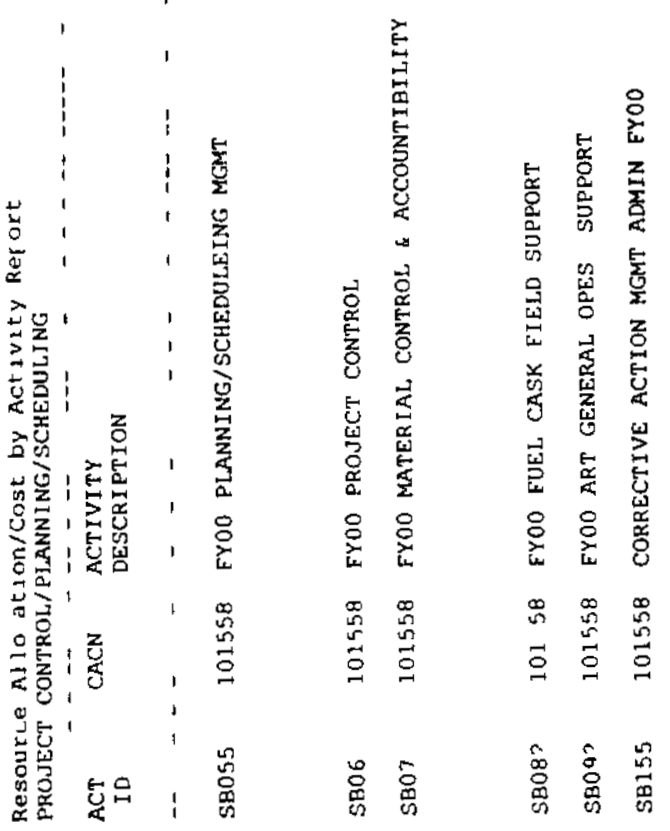




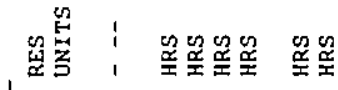

, 氙密 1888 :

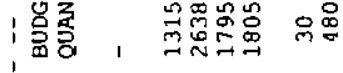

, $1 \frac{\pi}{\pi}$

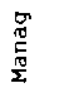

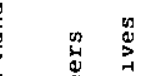

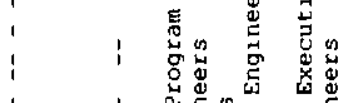

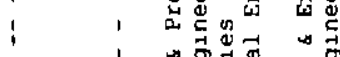

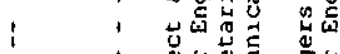

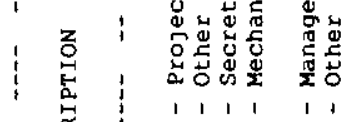

赑: yण0 11

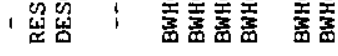

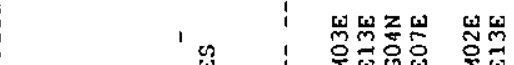

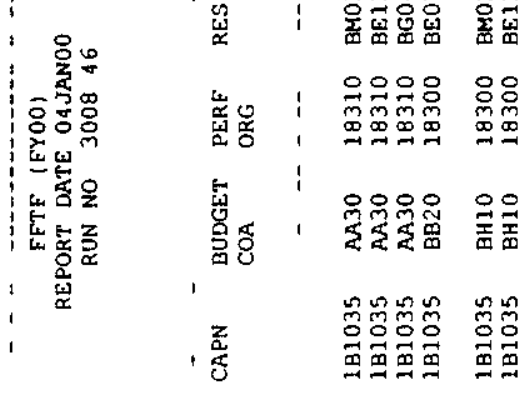

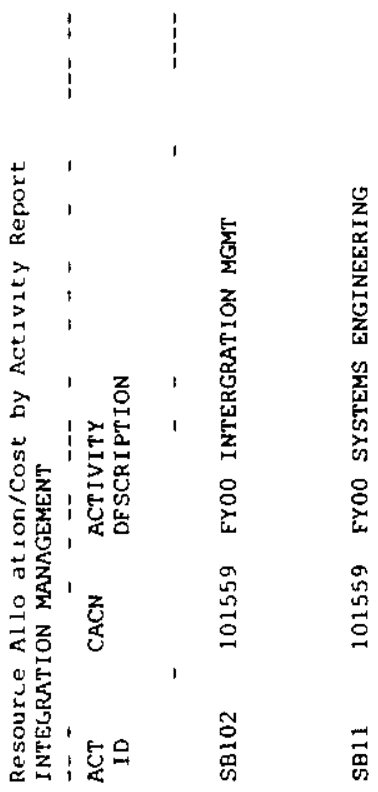




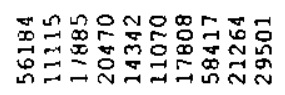

; 㫐若:

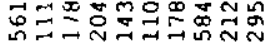

1

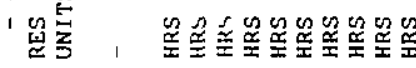

, 㫐

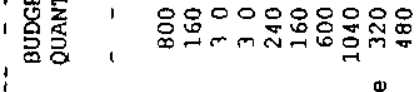

1 in

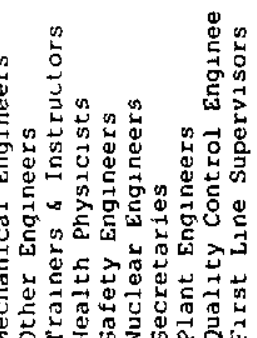

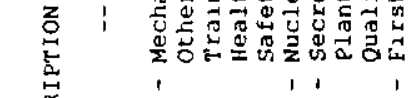

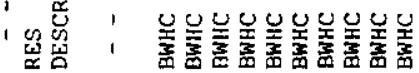

） ，

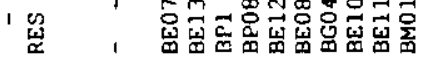

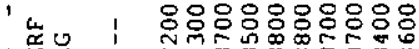

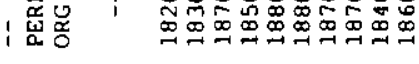

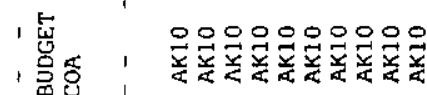

। $\quad x \infty \infty \infty \infty \infty \infty$

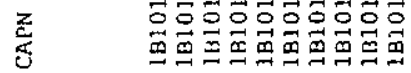

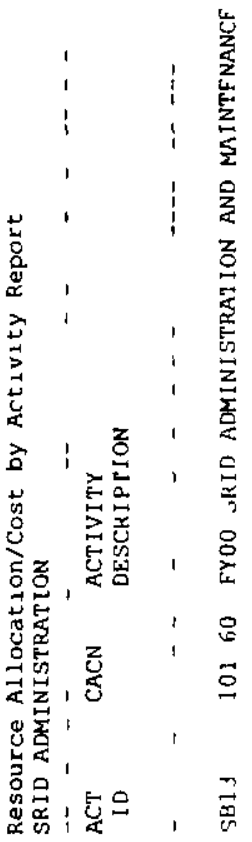




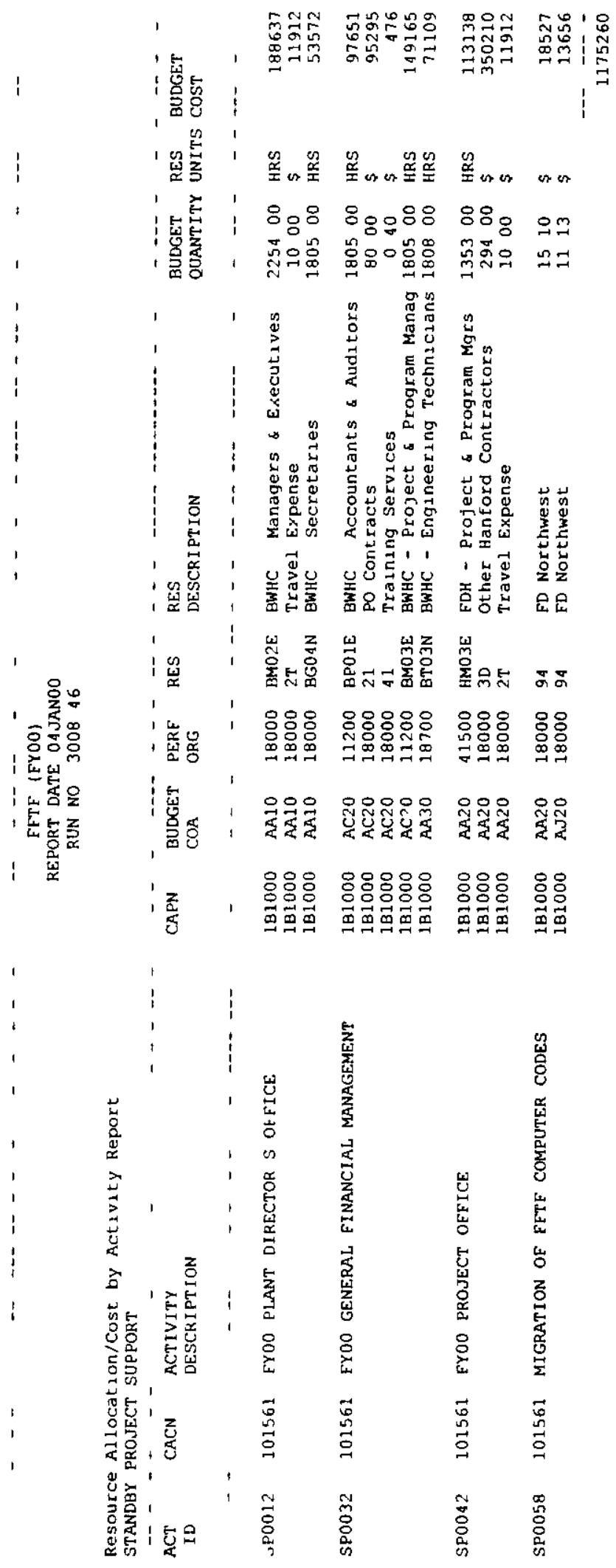




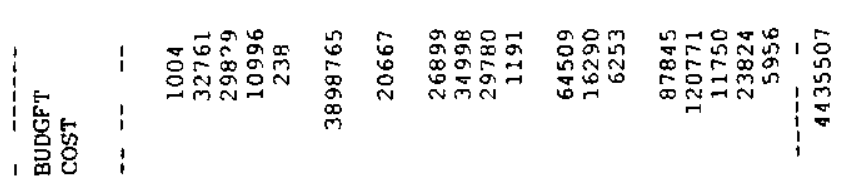

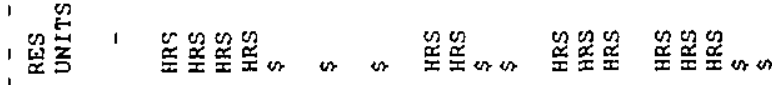

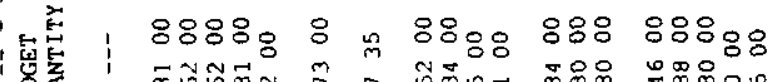

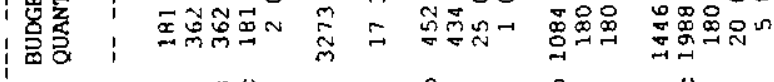

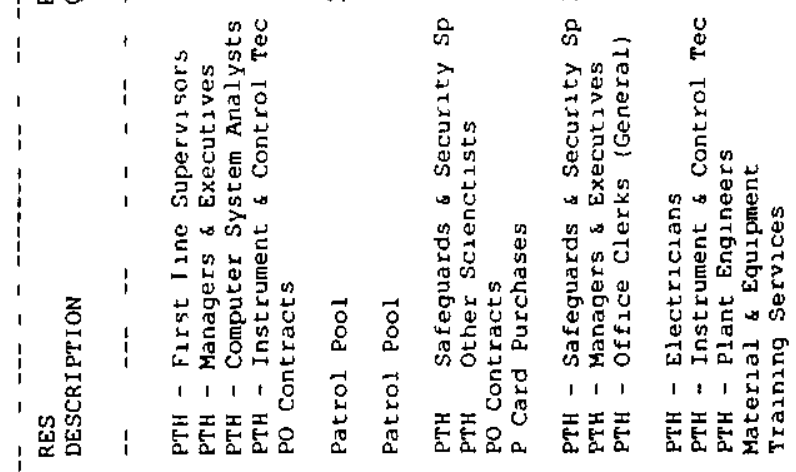

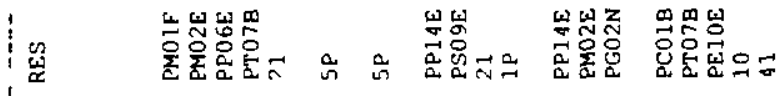

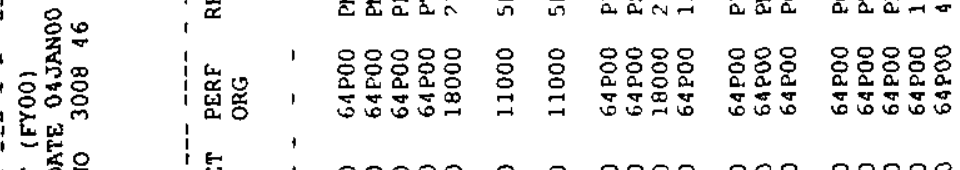

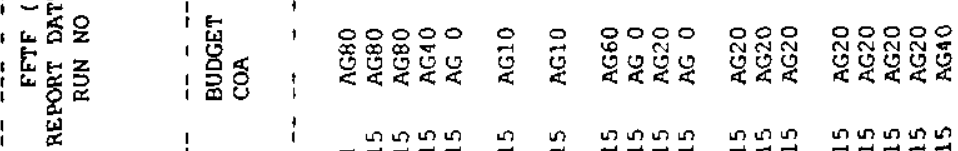

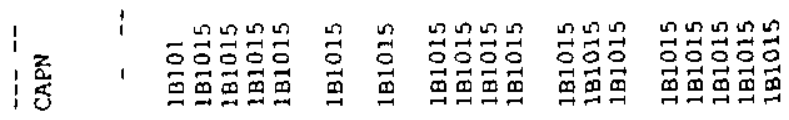

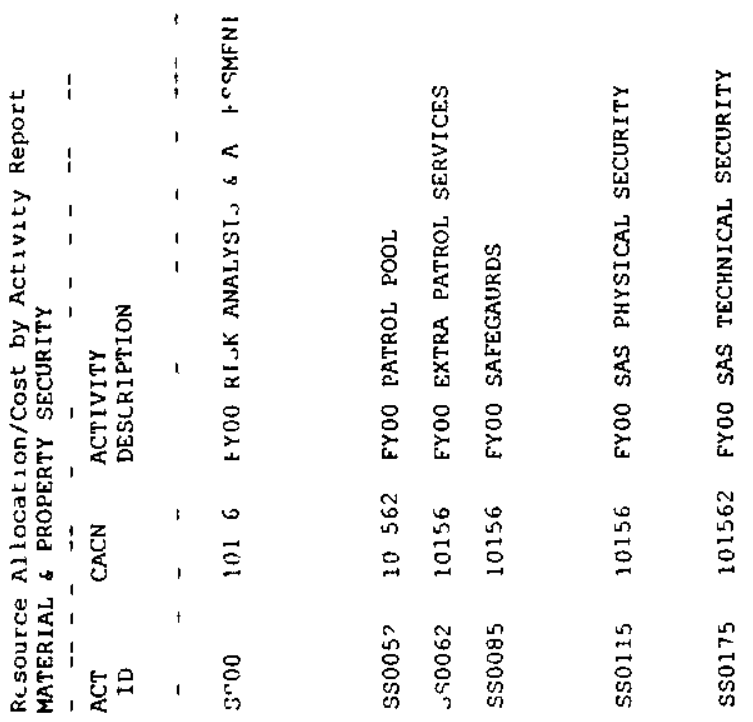


HNF SD FF SSP 050

Rev 8 Page 163

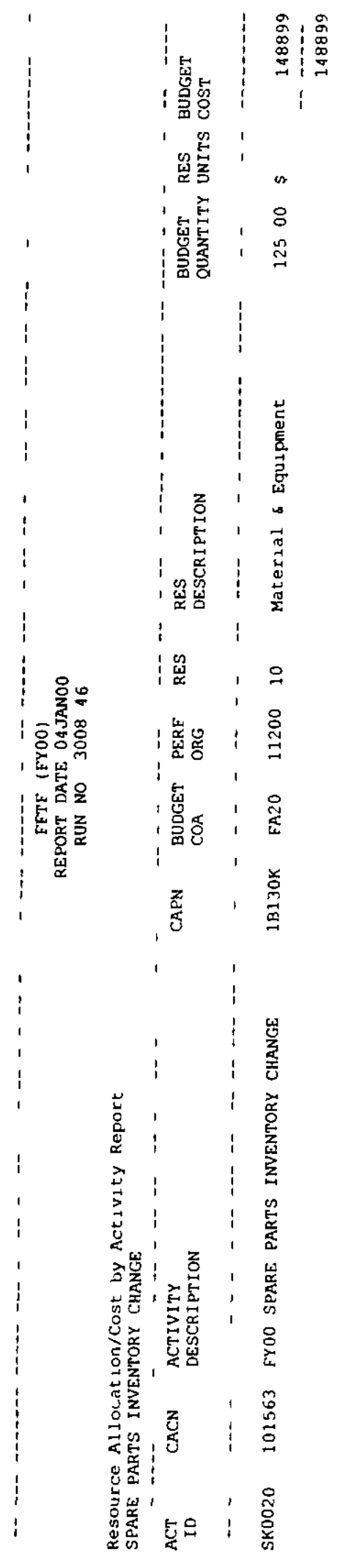


HNF SD FF-SSP-050

Rev 8 Page 164

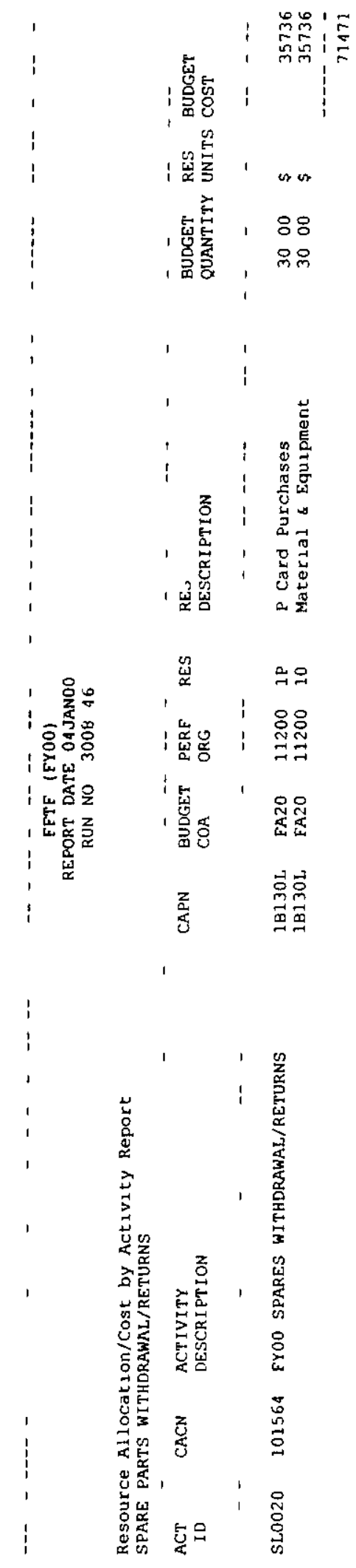


产㞓

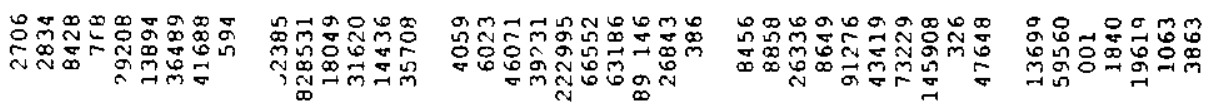

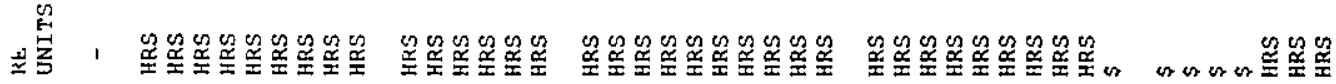

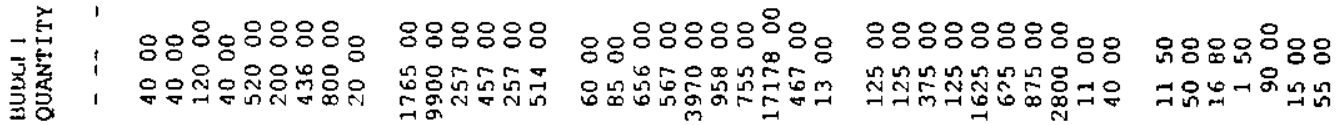

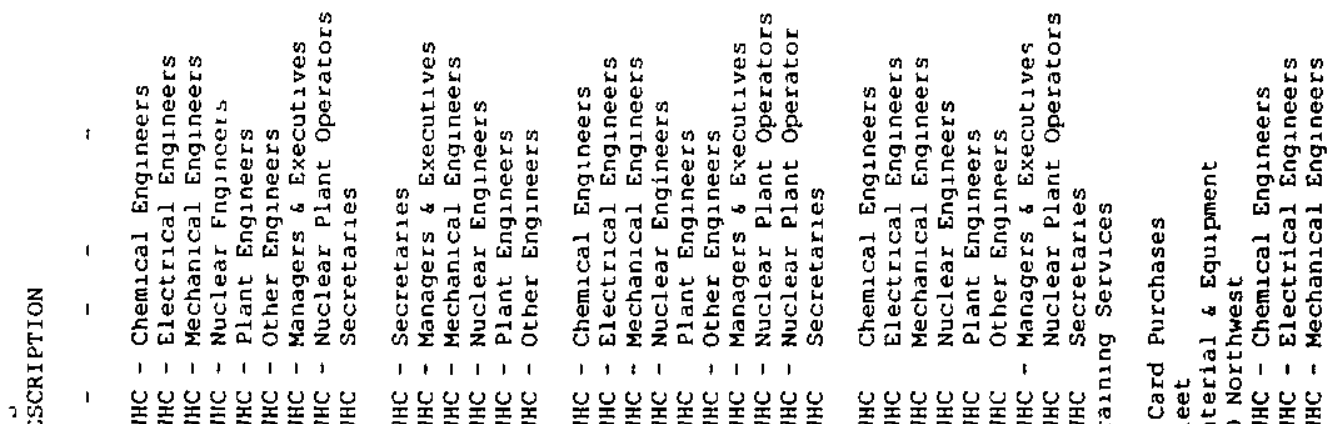

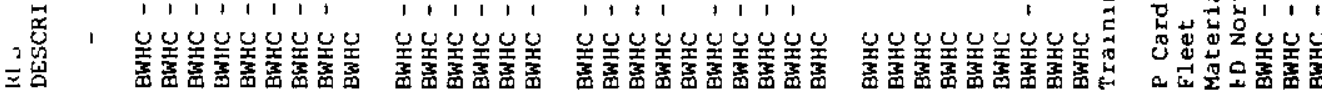

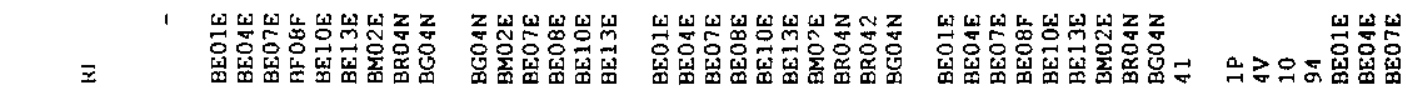

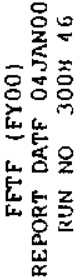

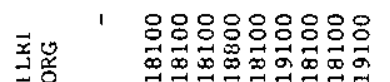

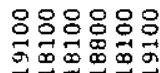

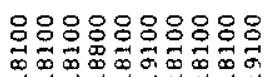

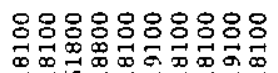

ㅇㅇㅇㅇㅇㅇㅇㅇㅇㅇㅛ

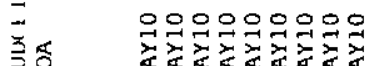

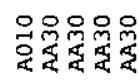

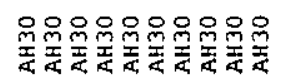

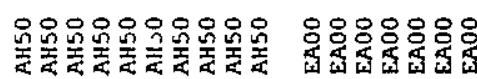

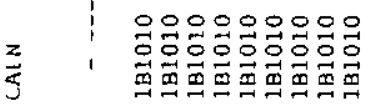

웅웅응응으음

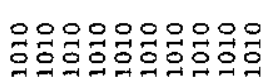

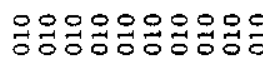

0000000

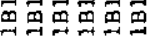

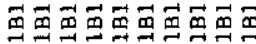

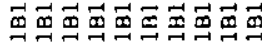

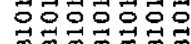

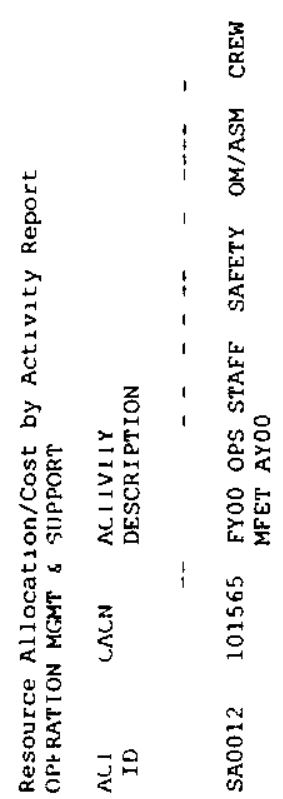

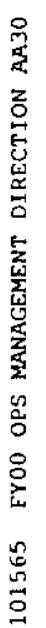

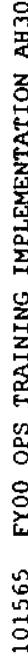

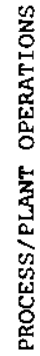

娄

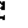

施

울

$\stackrel{ }{1}$

to

惢

自思思思思思

峦

운?

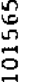

$\stackrel{\leftrightarrow}{\circ}$

$\vec{\Xi}$

足

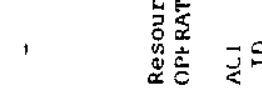

욿

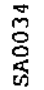

品

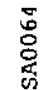




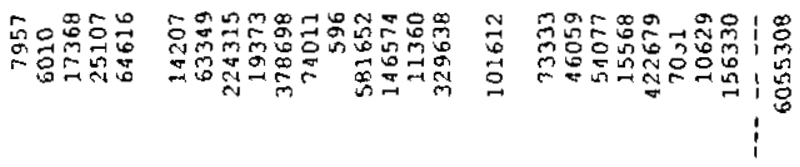

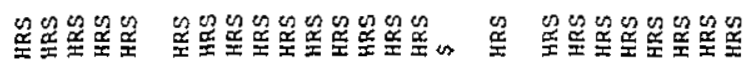

88888 8888888:88\% : 88888888

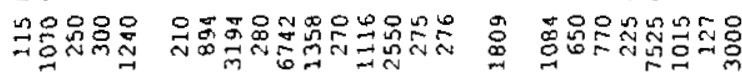

$\begin{array}{ll} & \\ & \\ n & \end{array}$

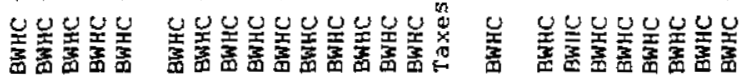

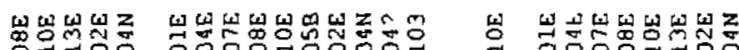

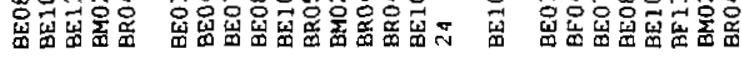

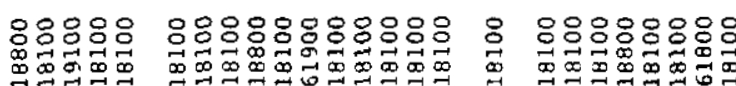

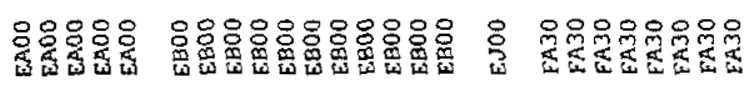

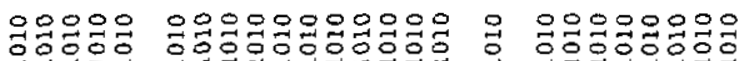

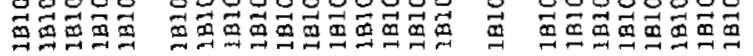

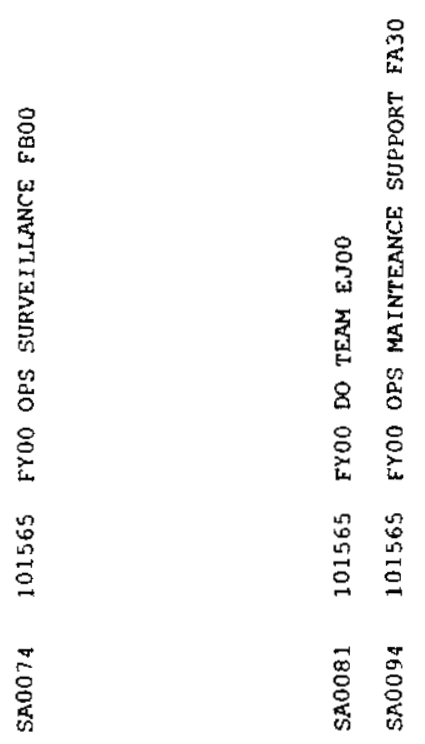




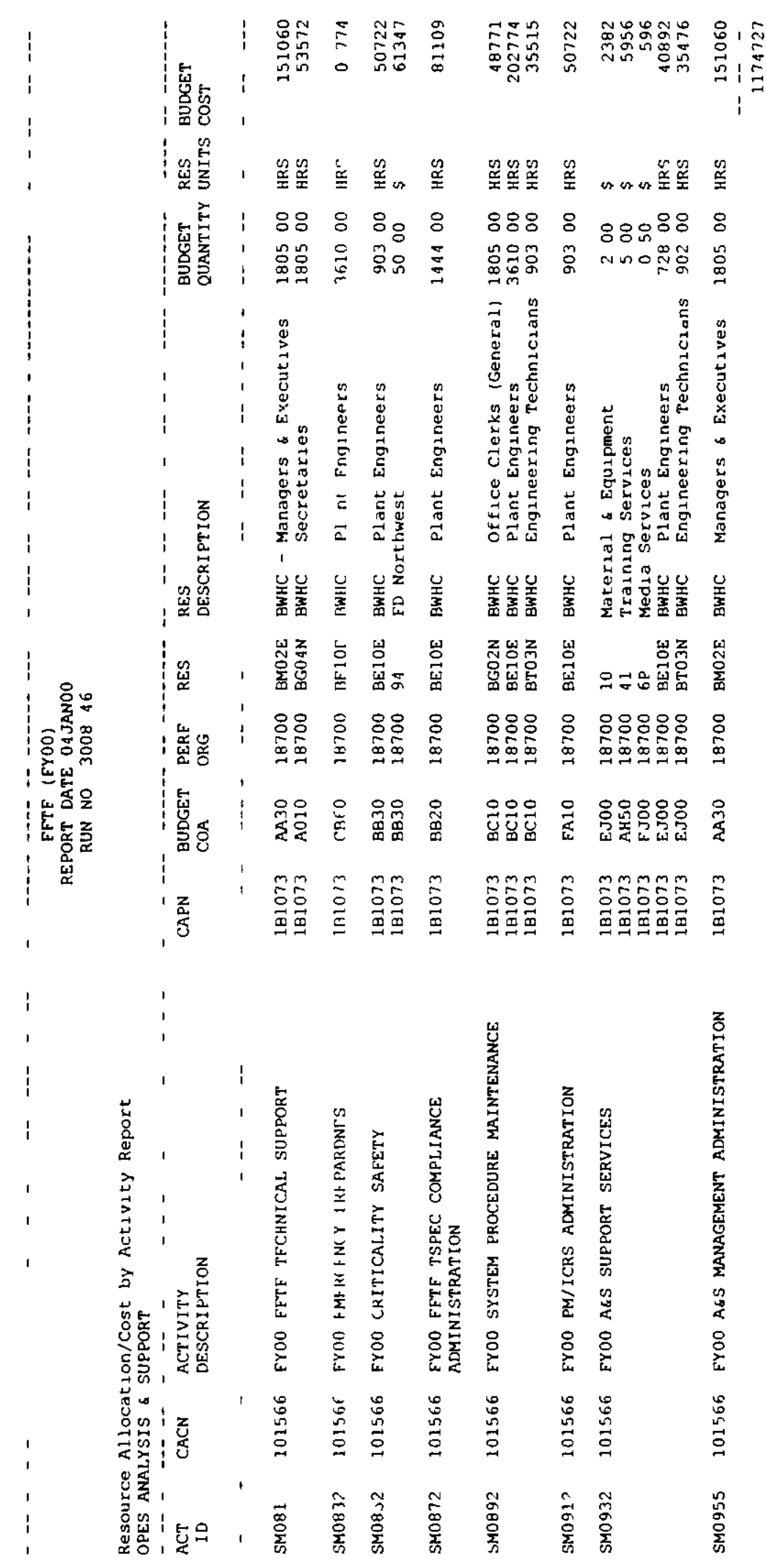




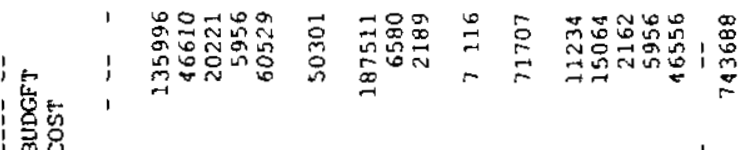

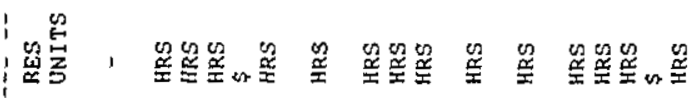

| 危

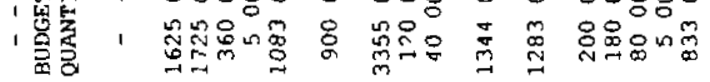

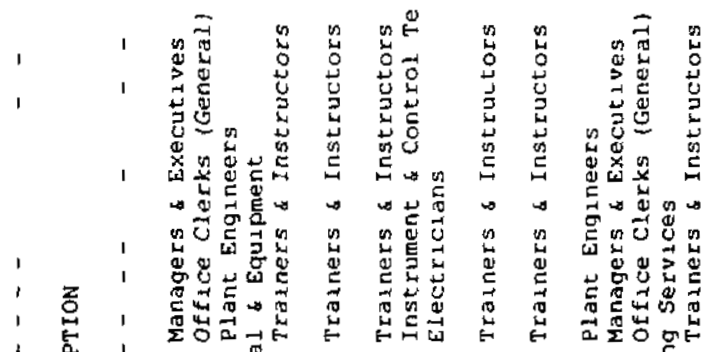

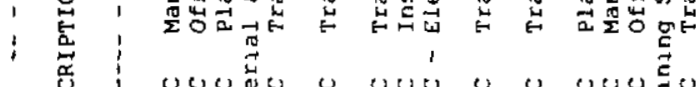

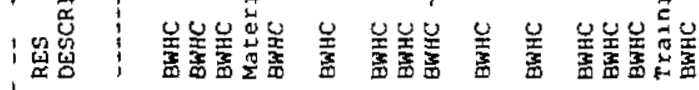

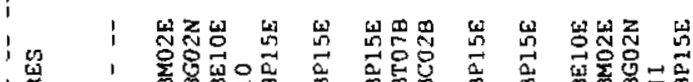

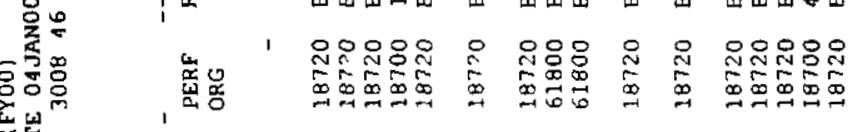

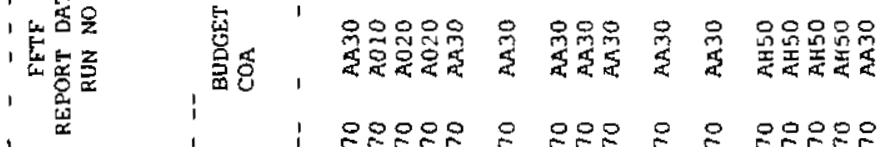

㴽

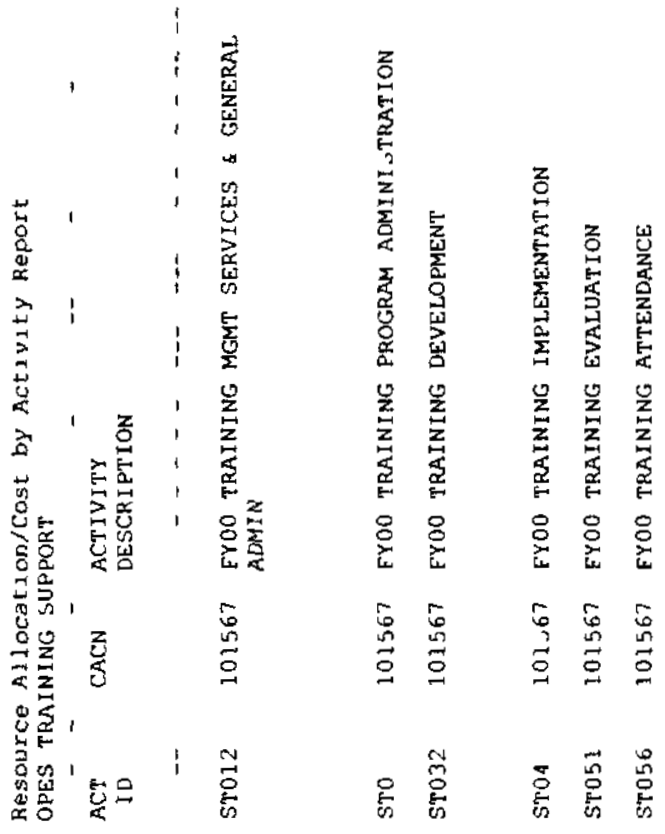




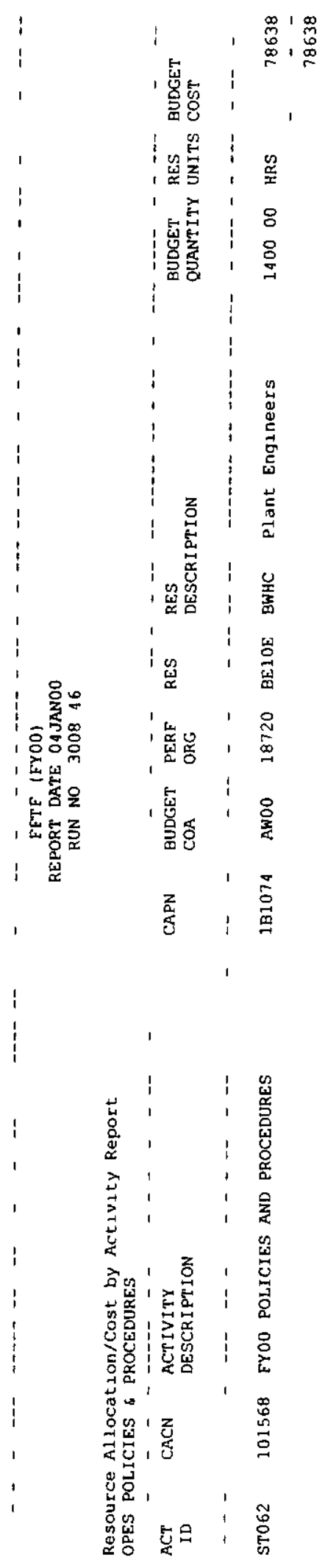




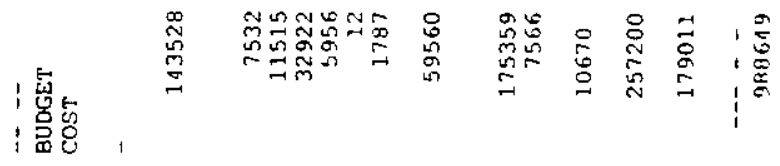

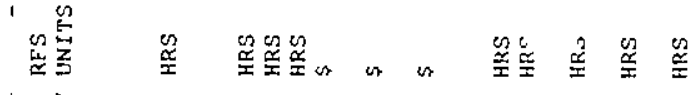

擖蓄

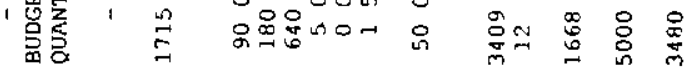

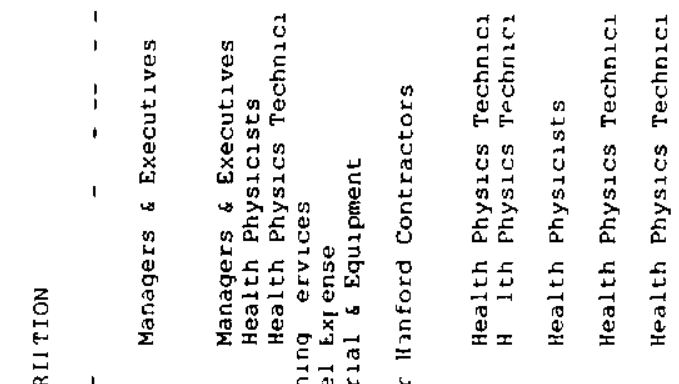

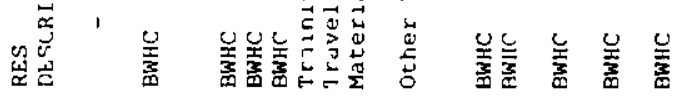

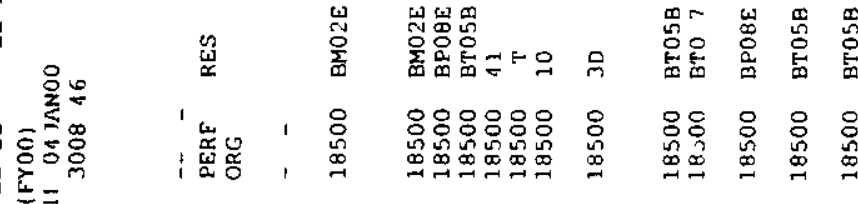

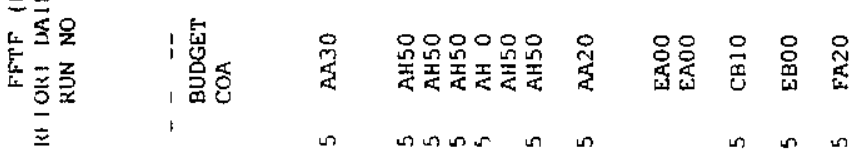

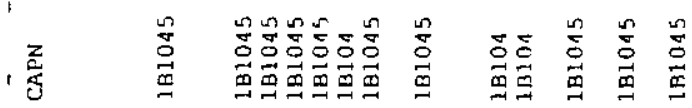

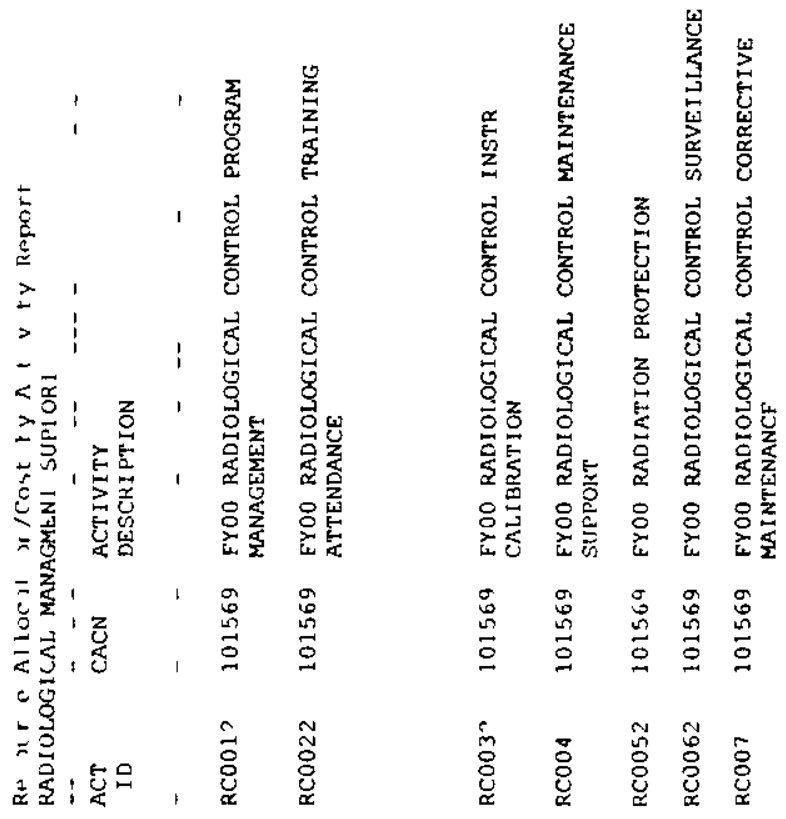


, 密崖

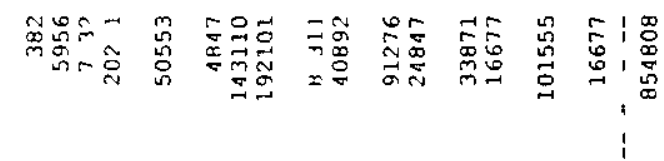

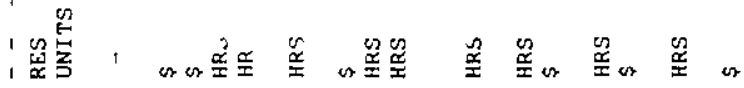

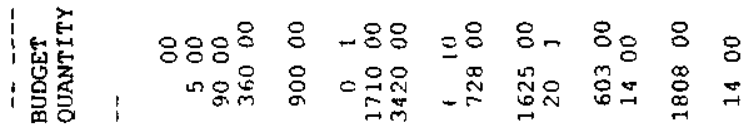

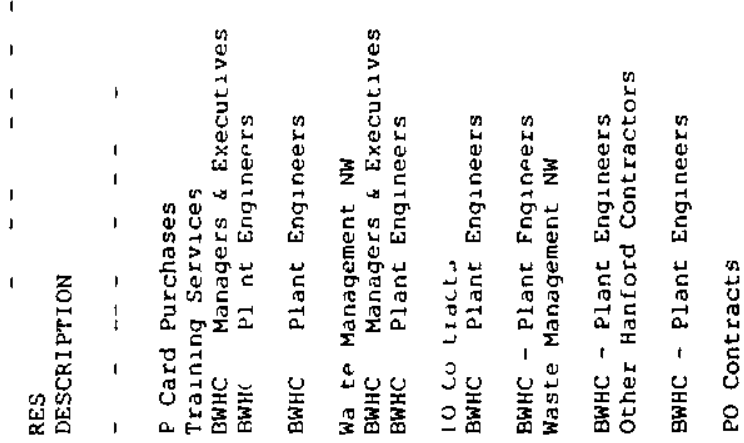

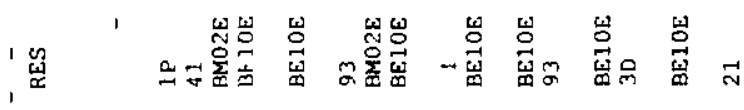

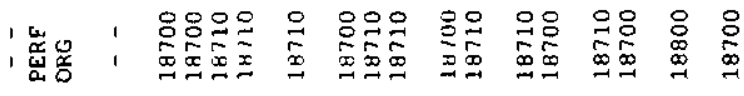

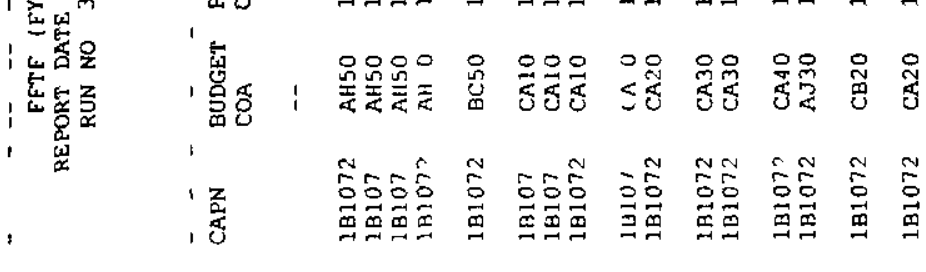

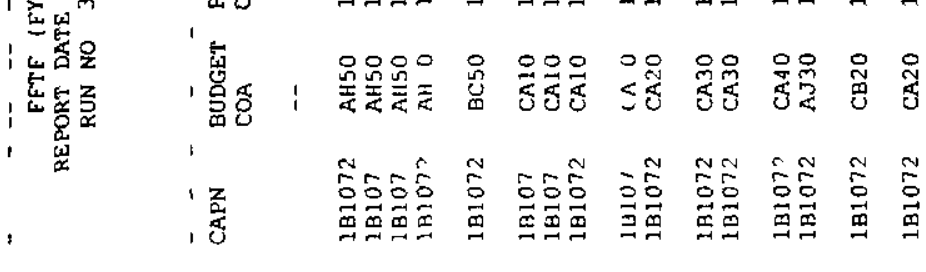

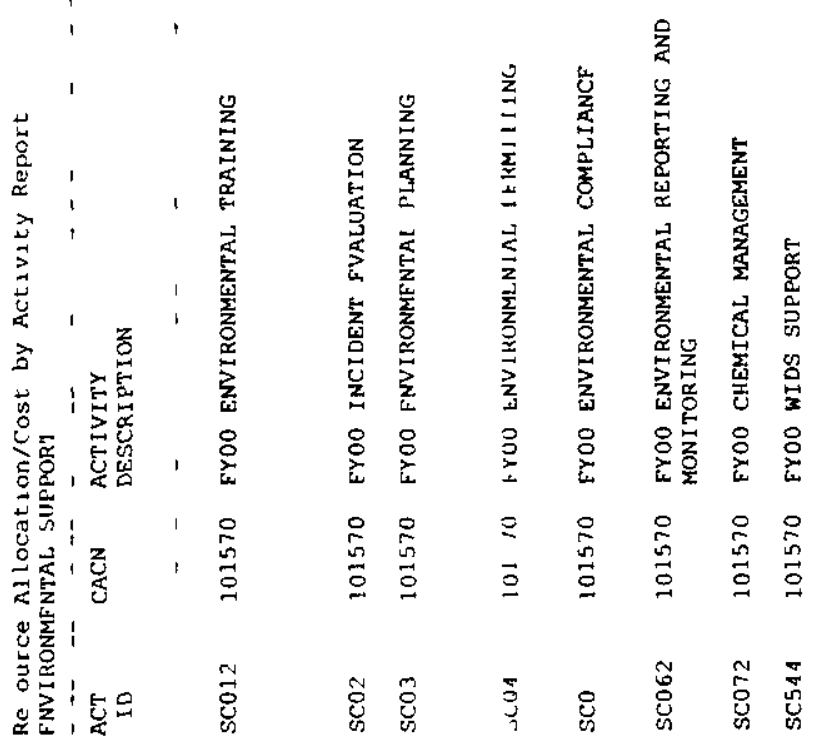




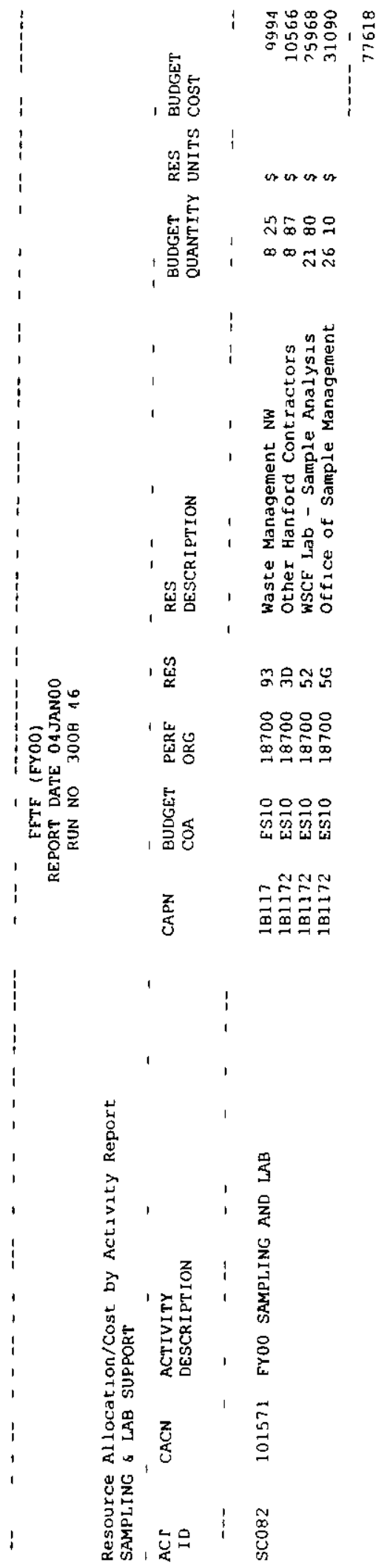




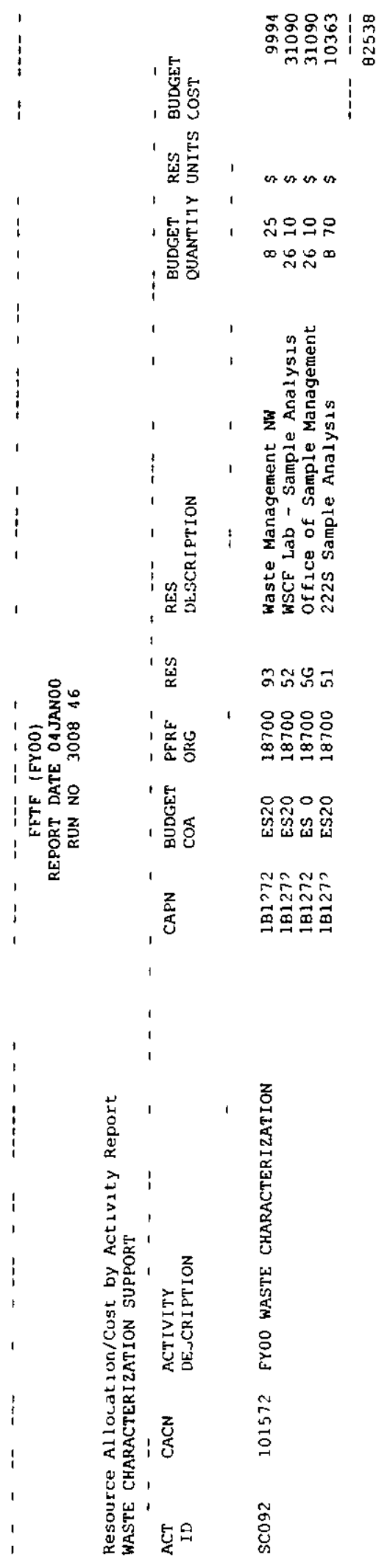


HNF-SD-FF SSP 050

Rev 8 Page 174

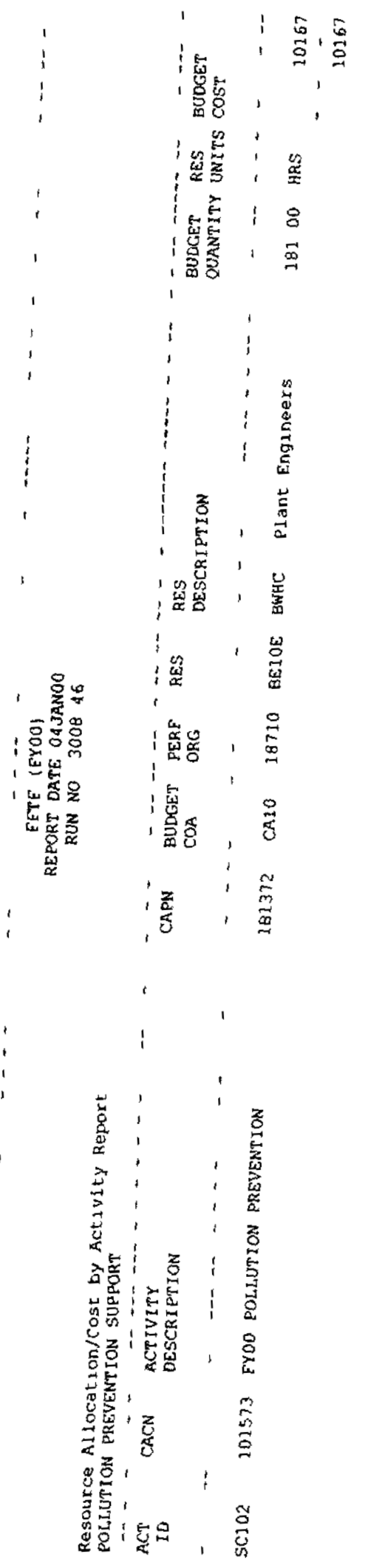


HNF SD-FF SSP-050

Rev 8 Page 175

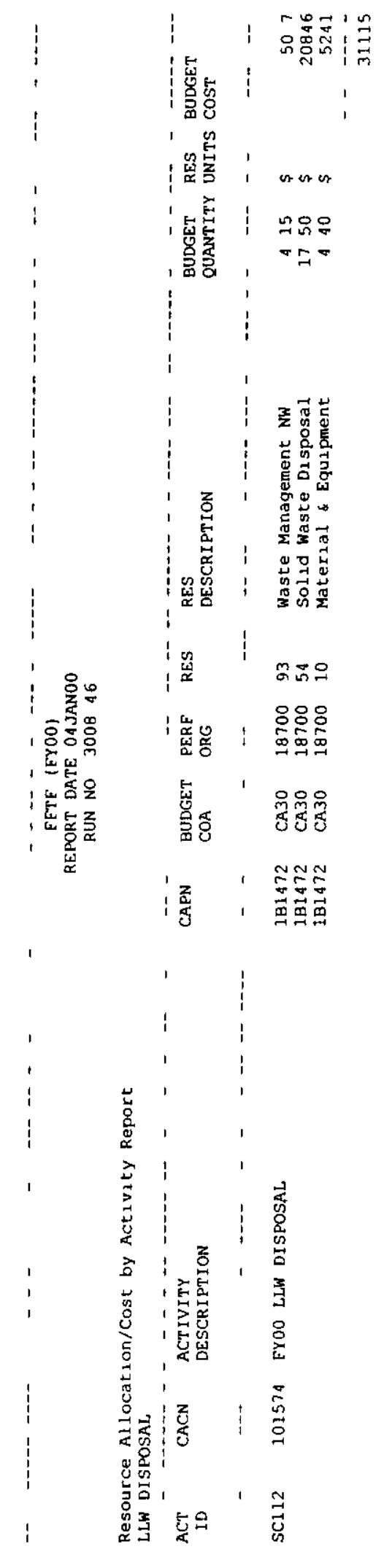



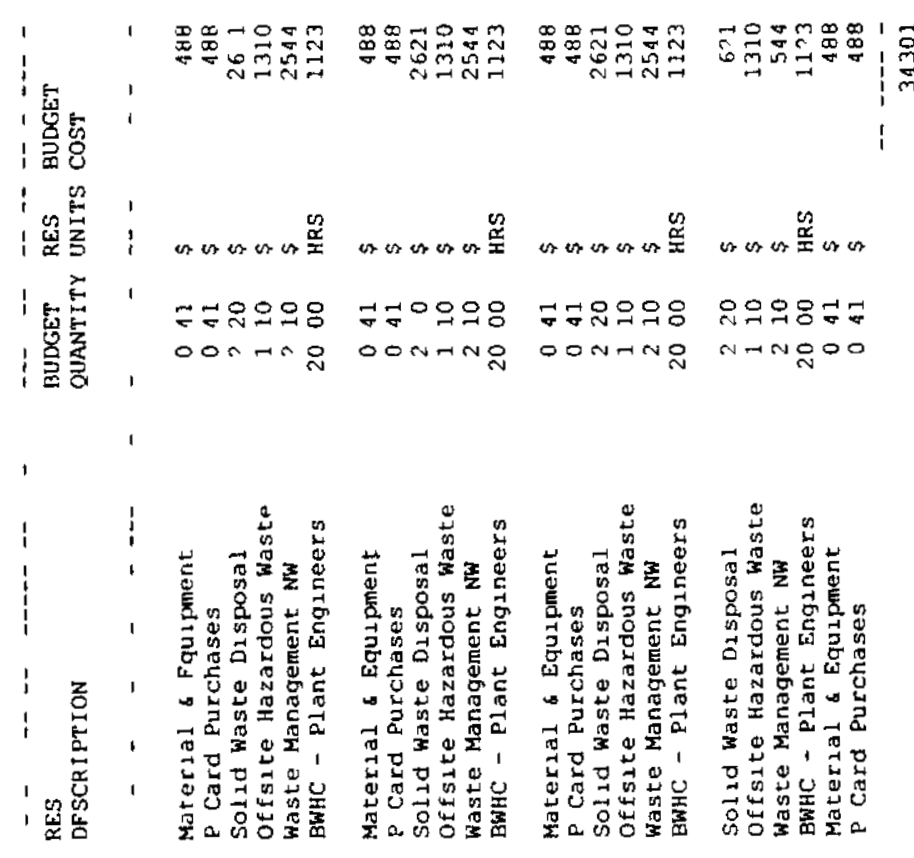

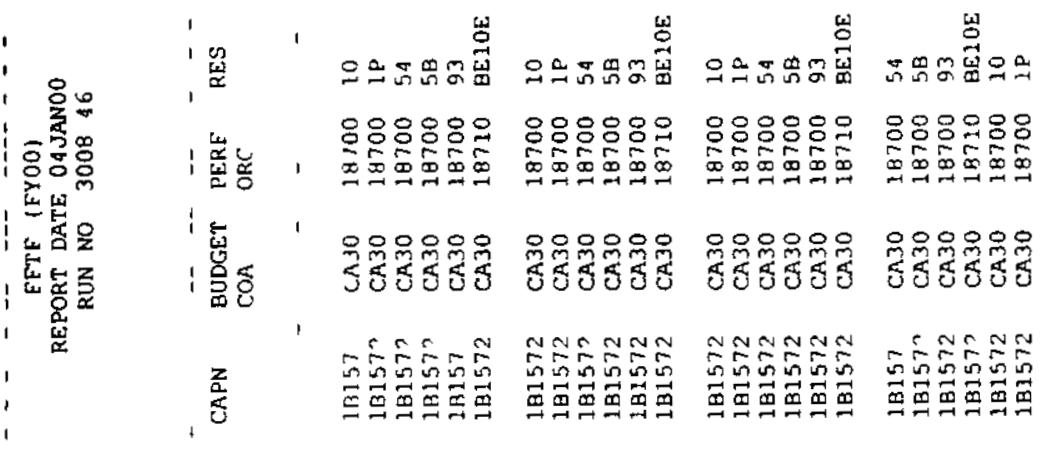

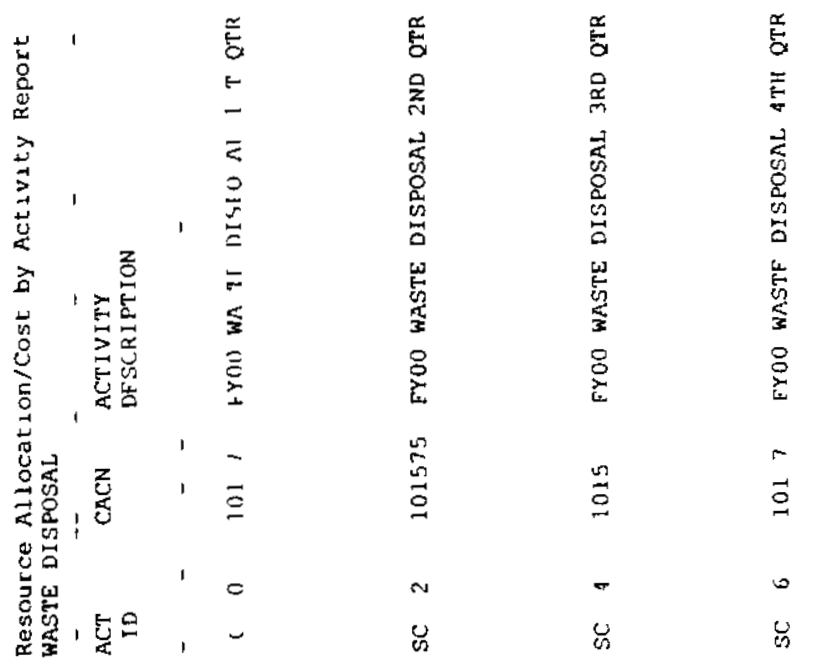




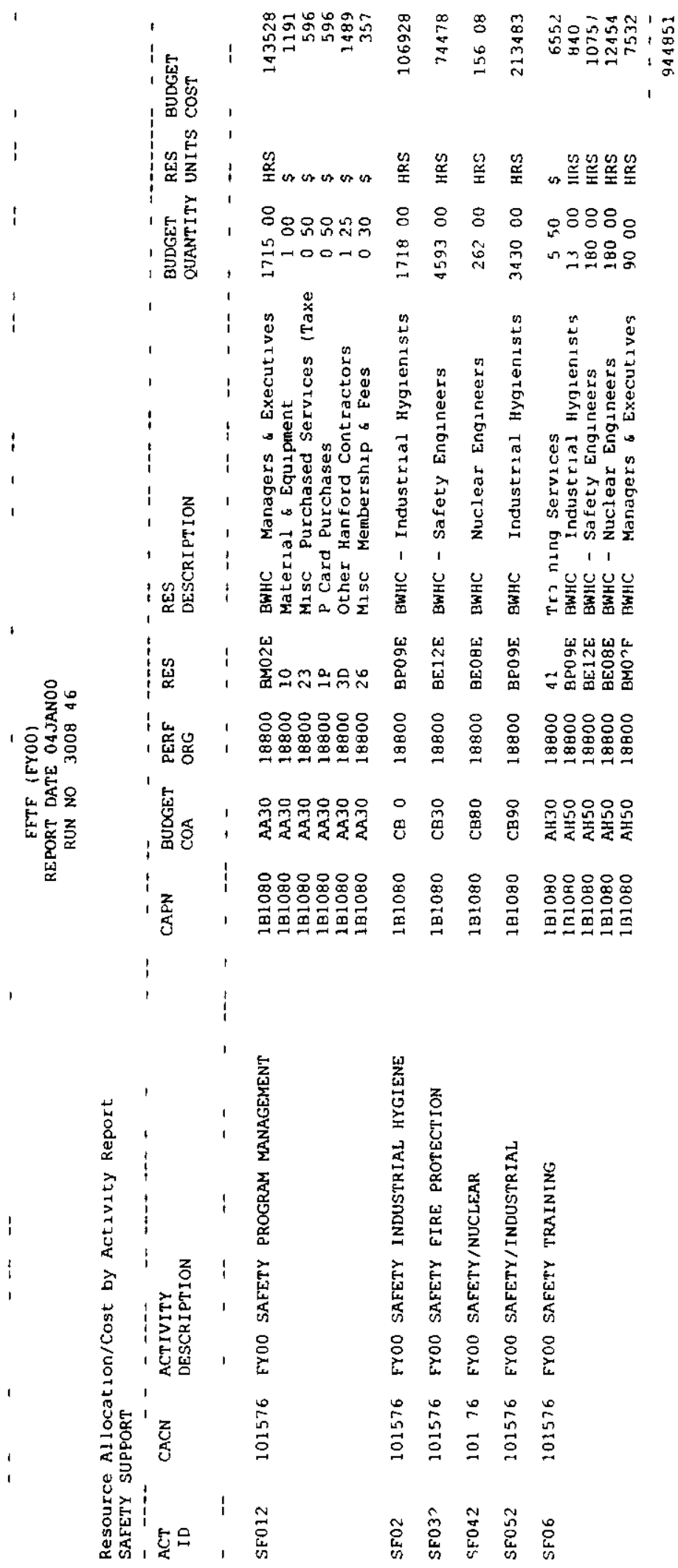



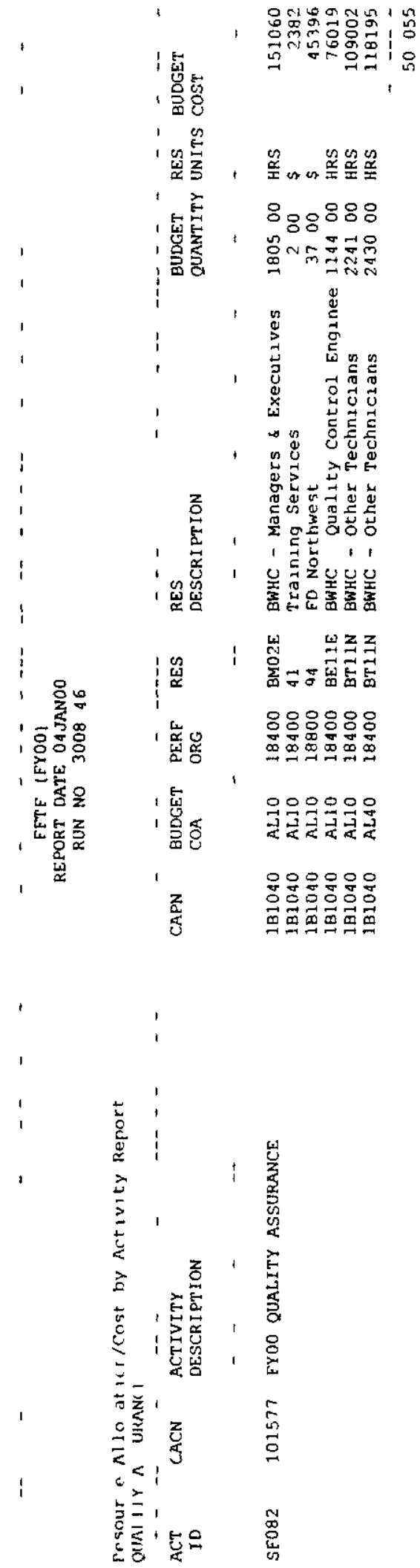

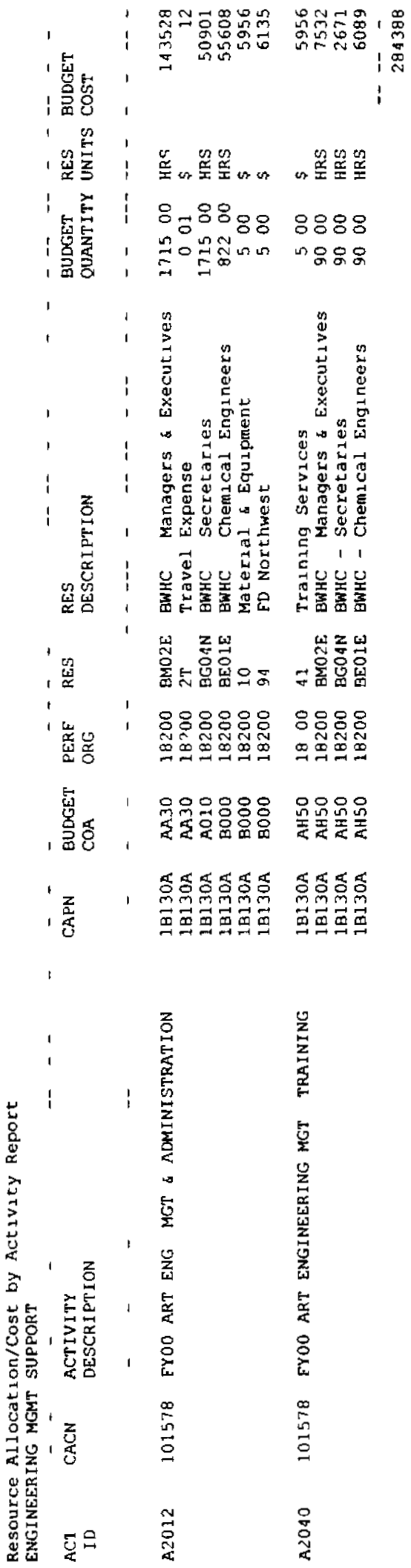


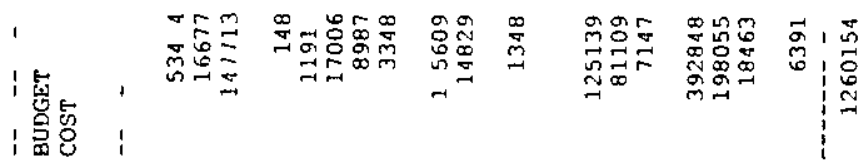

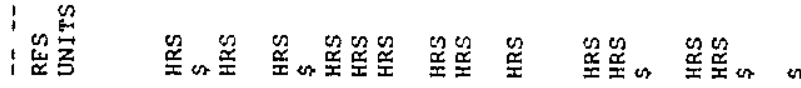

'苮

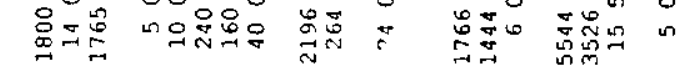

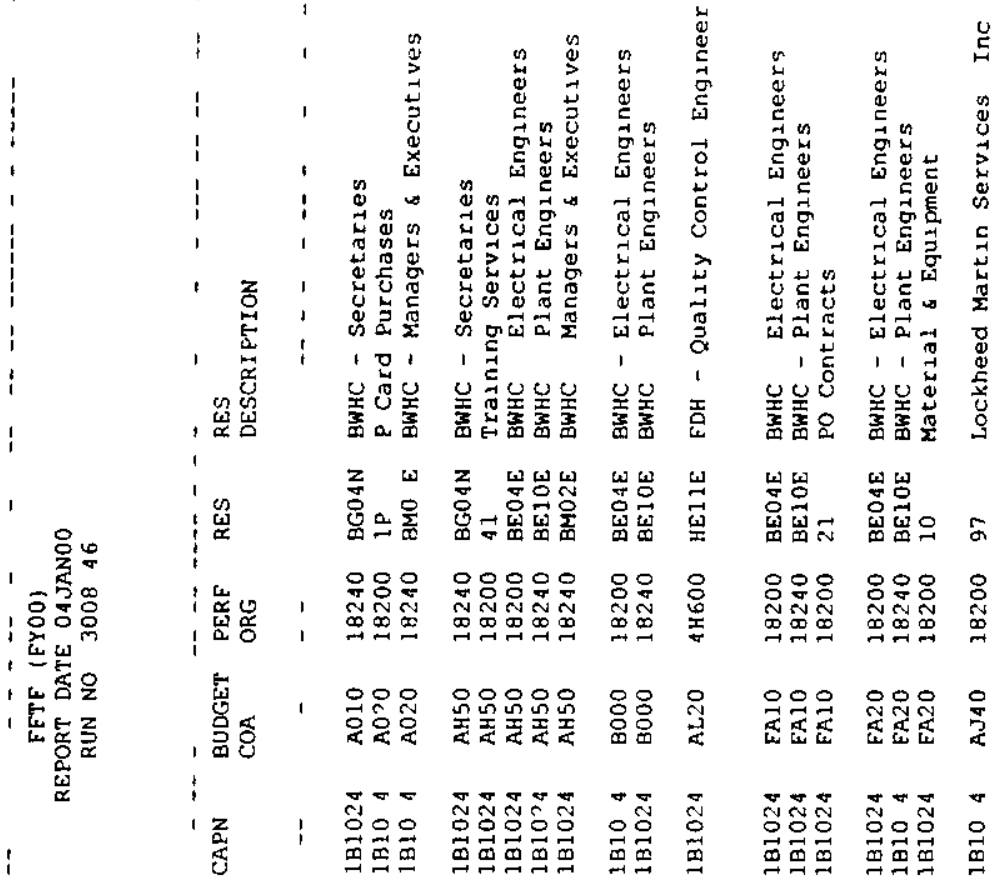

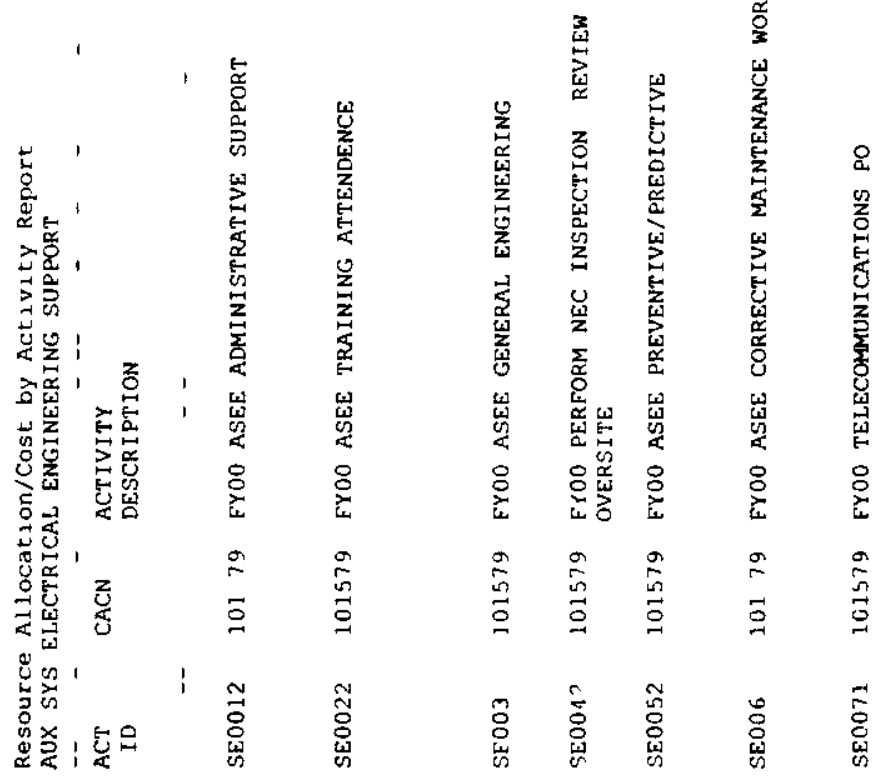



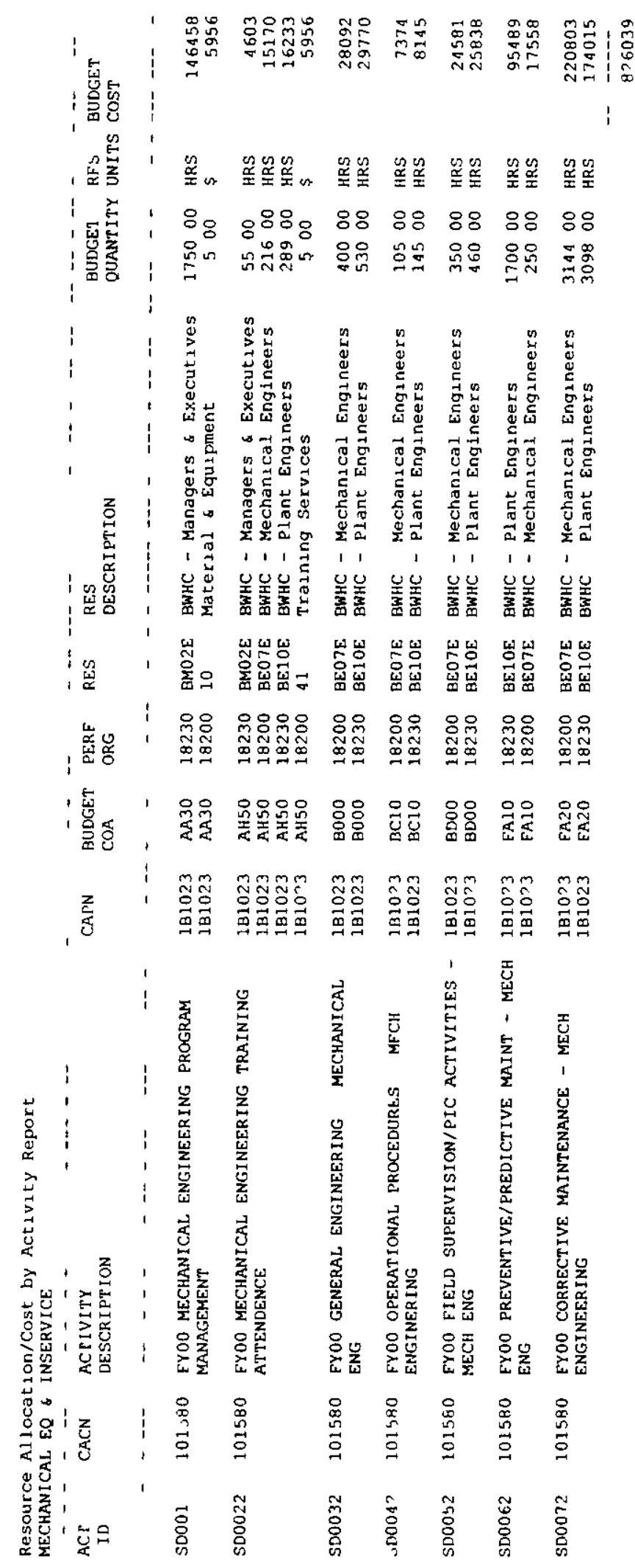


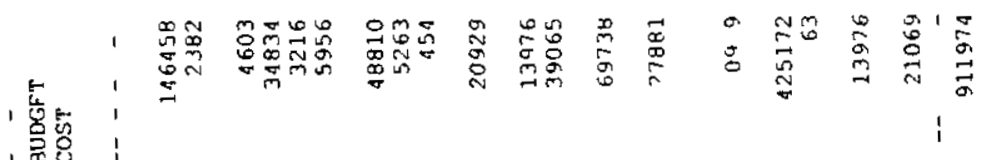

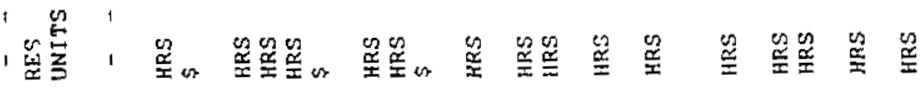

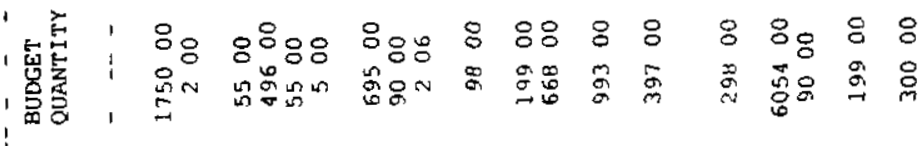

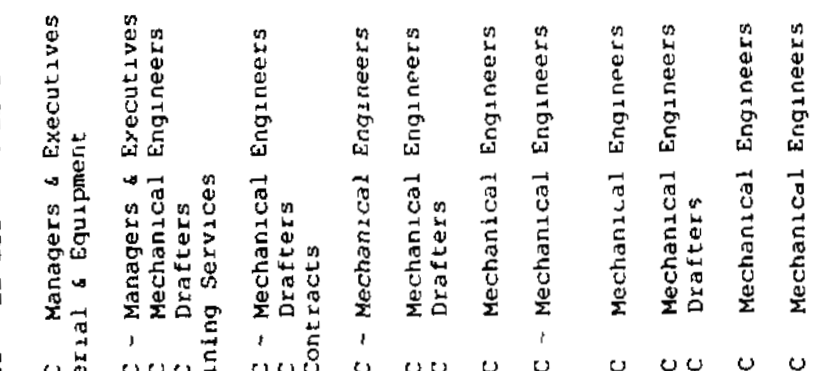

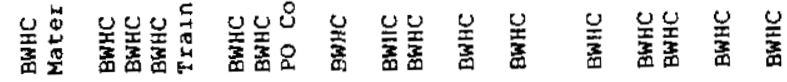

管

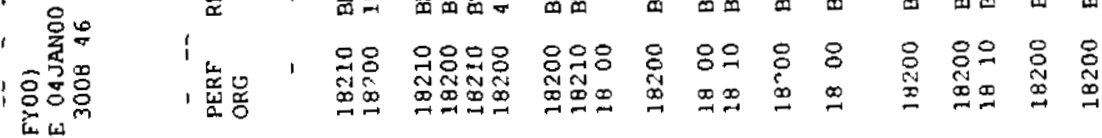

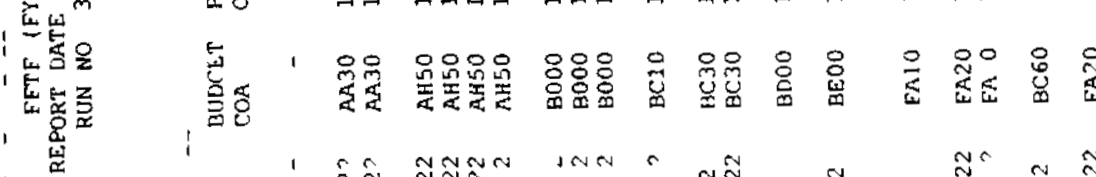

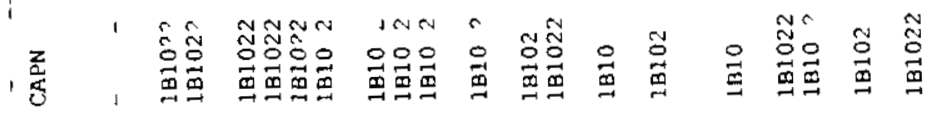

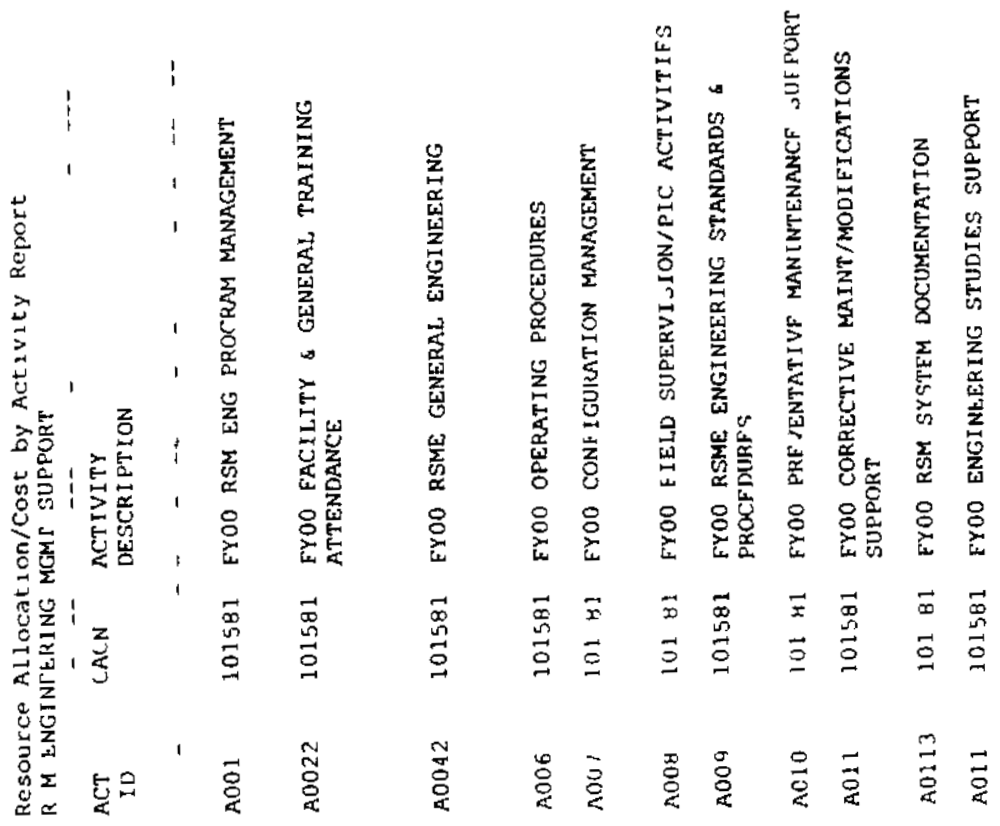




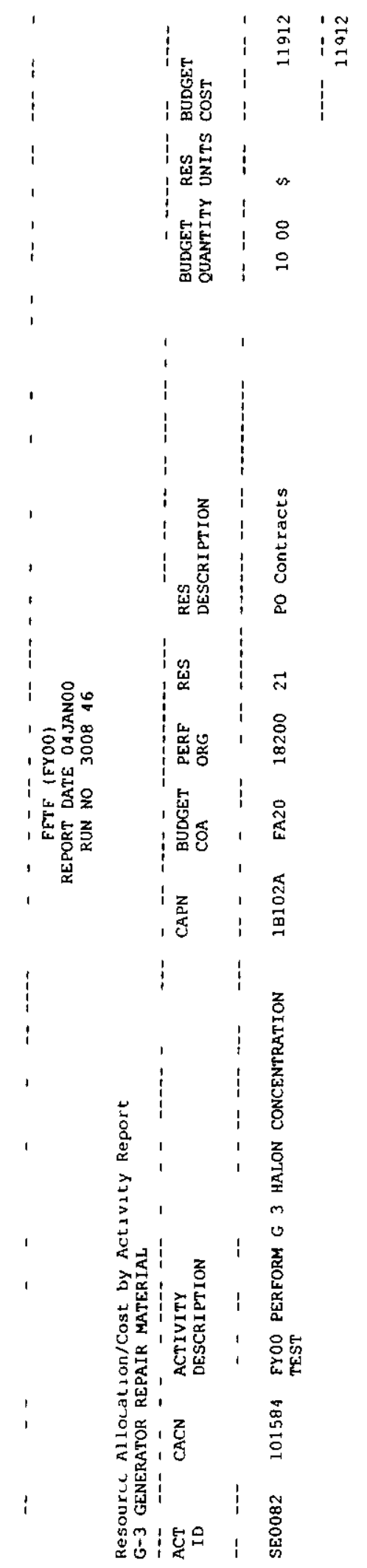


1

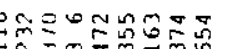

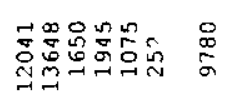

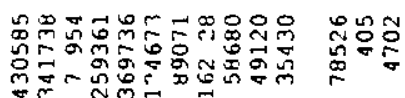

i

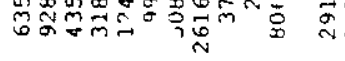

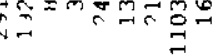

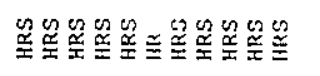

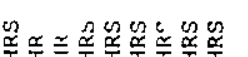

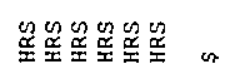

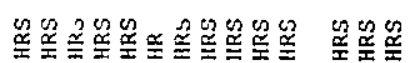

'泀 ' 8888888888

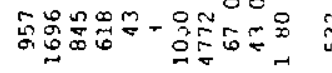

\section{8 $888888 \%$}

88:88:

88888888:8: 88:

i品言

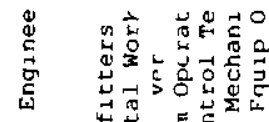

要

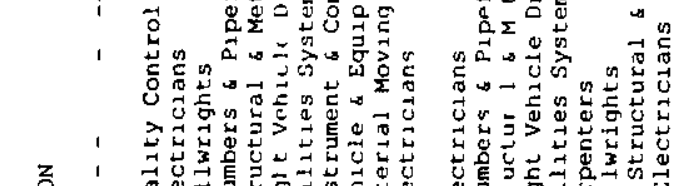

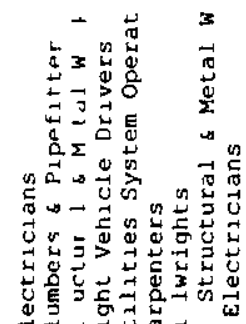

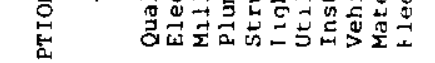

由)

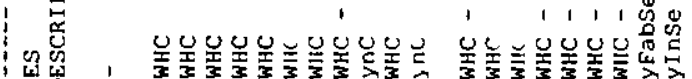

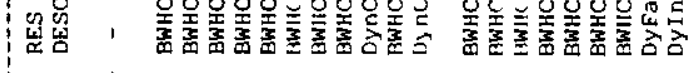

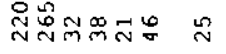

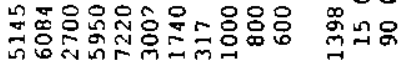




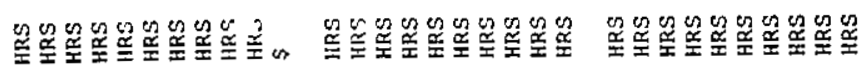
888888888888888888888 88888888:8

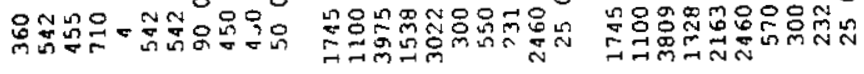

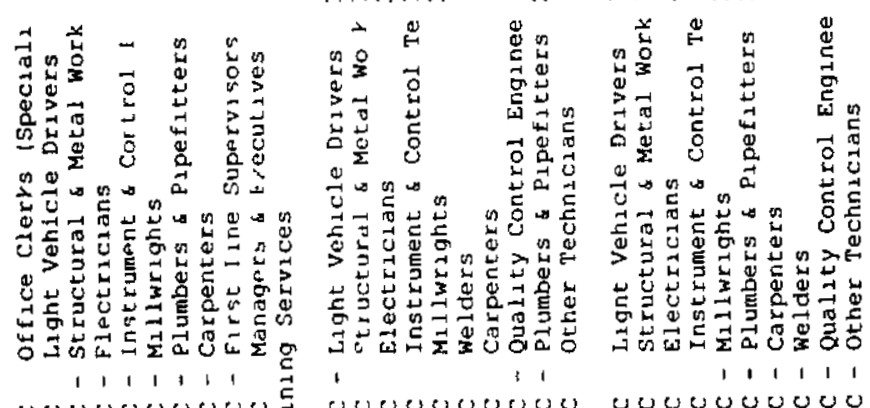

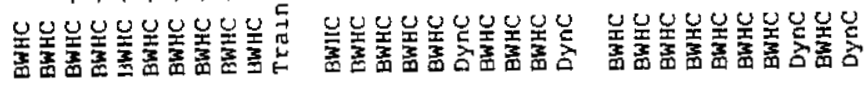

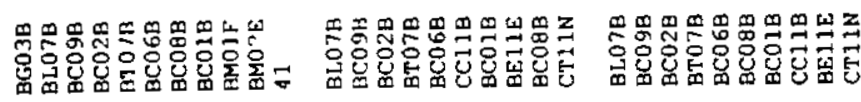

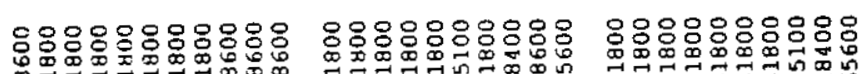

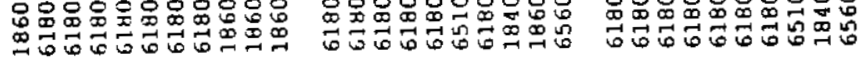

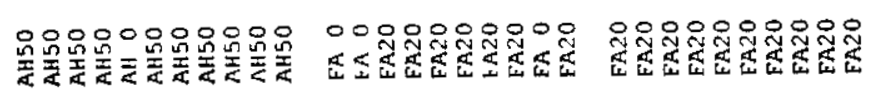

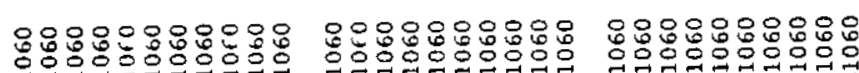

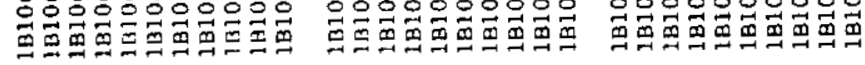

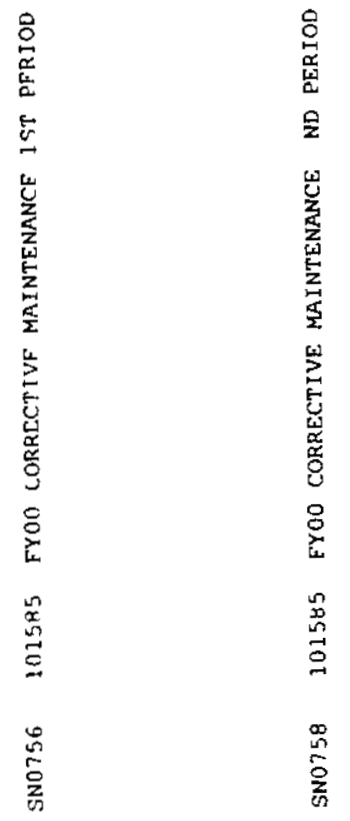



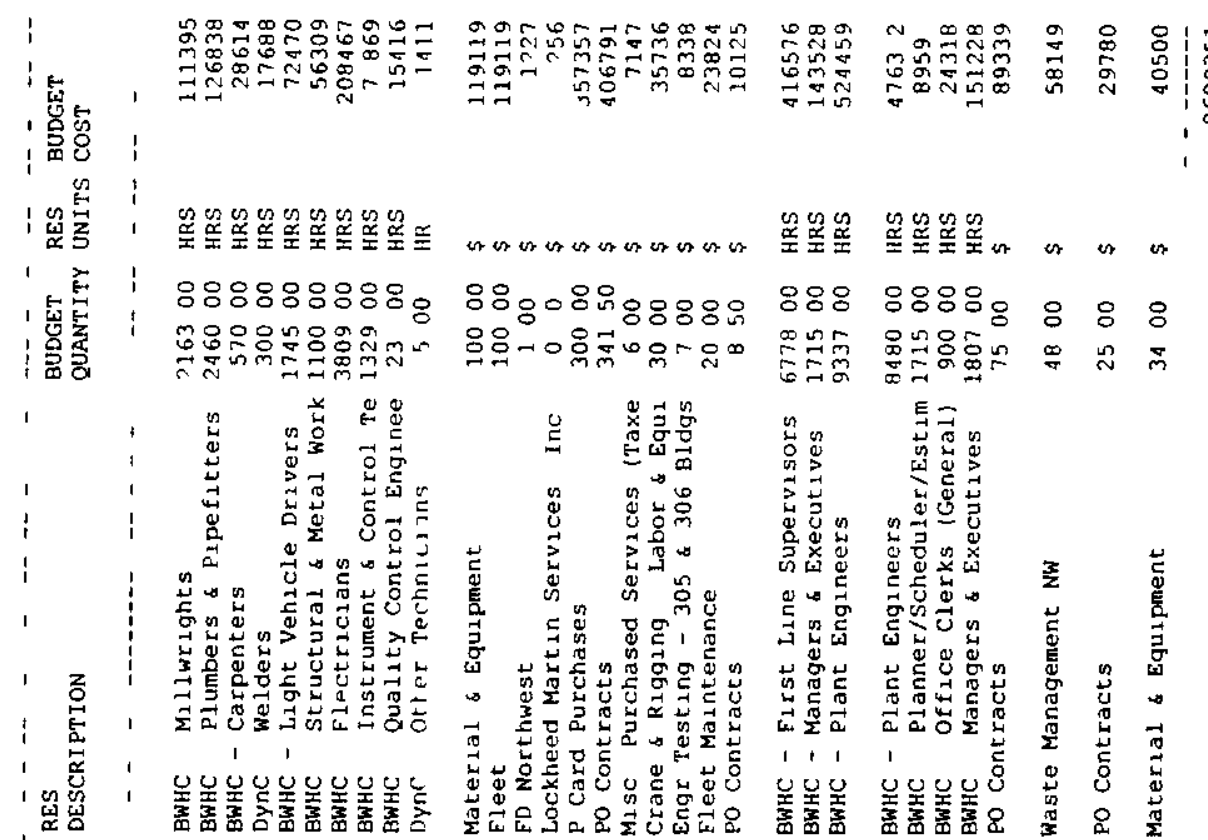

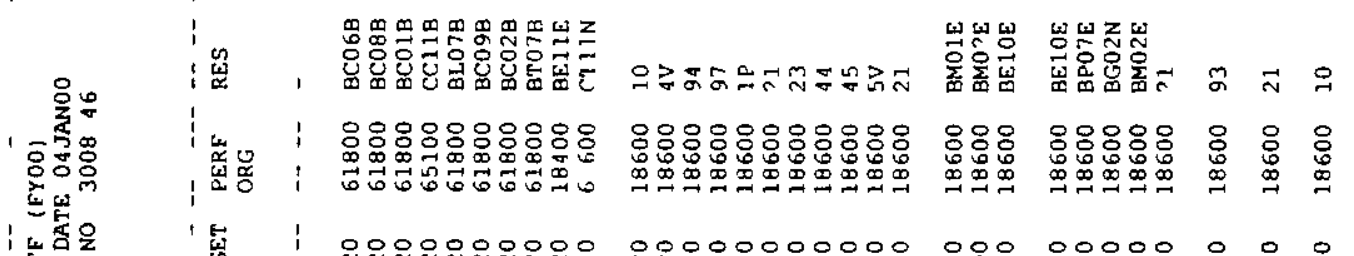

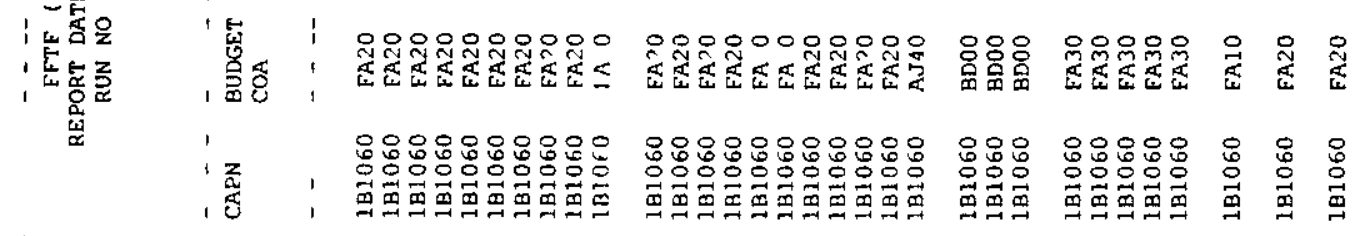

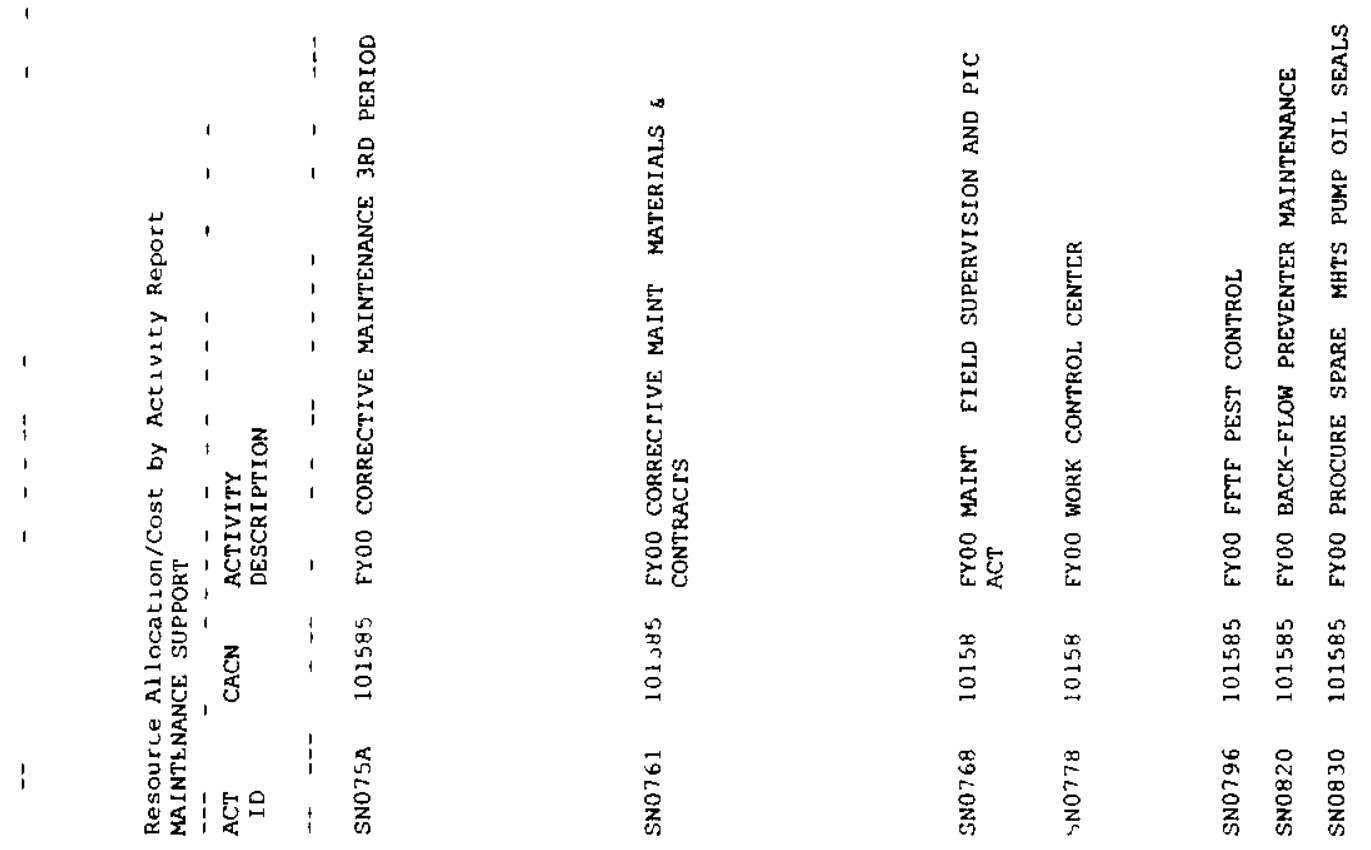




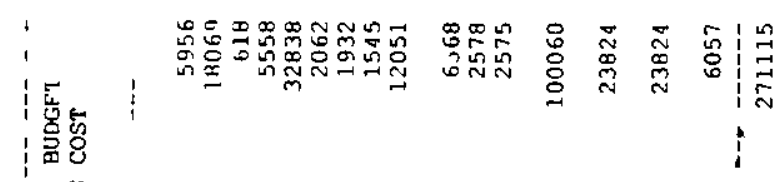

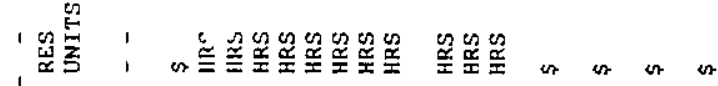

, 氙萜

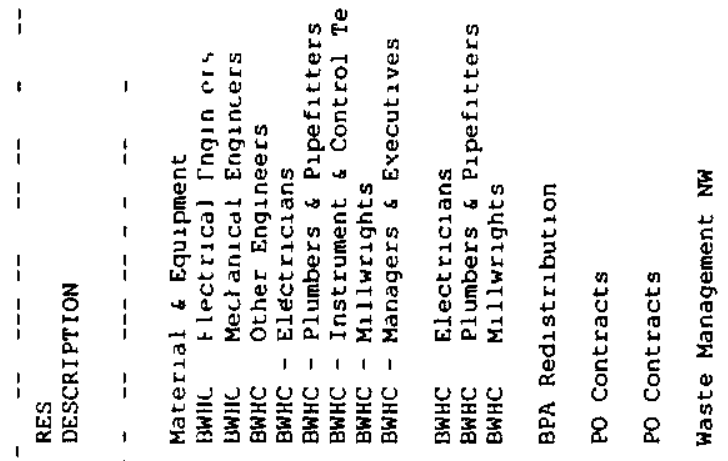

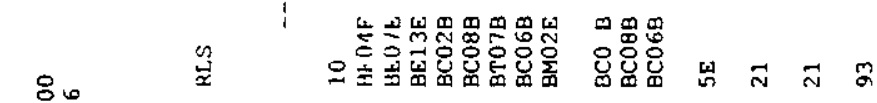

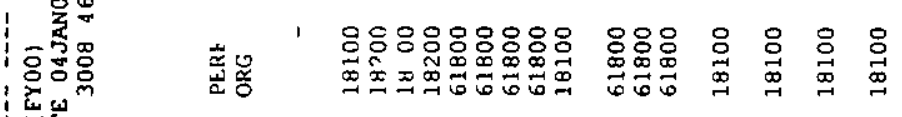

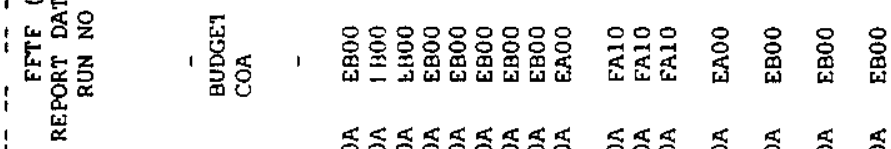

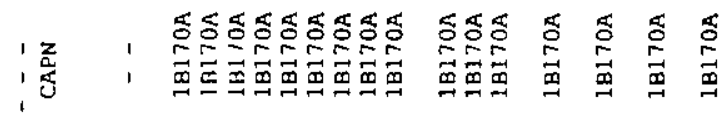

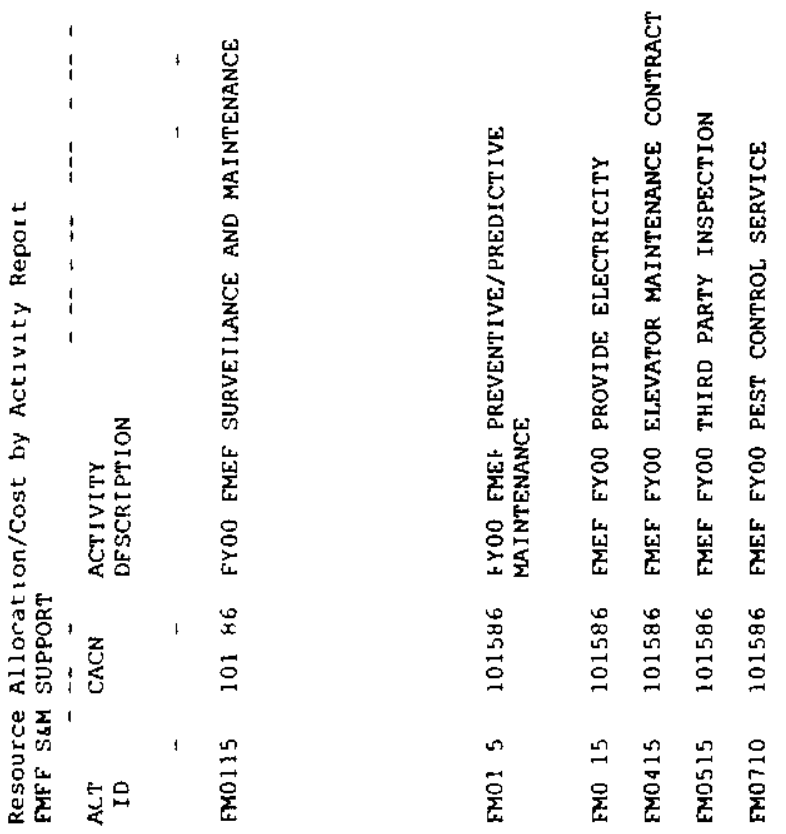




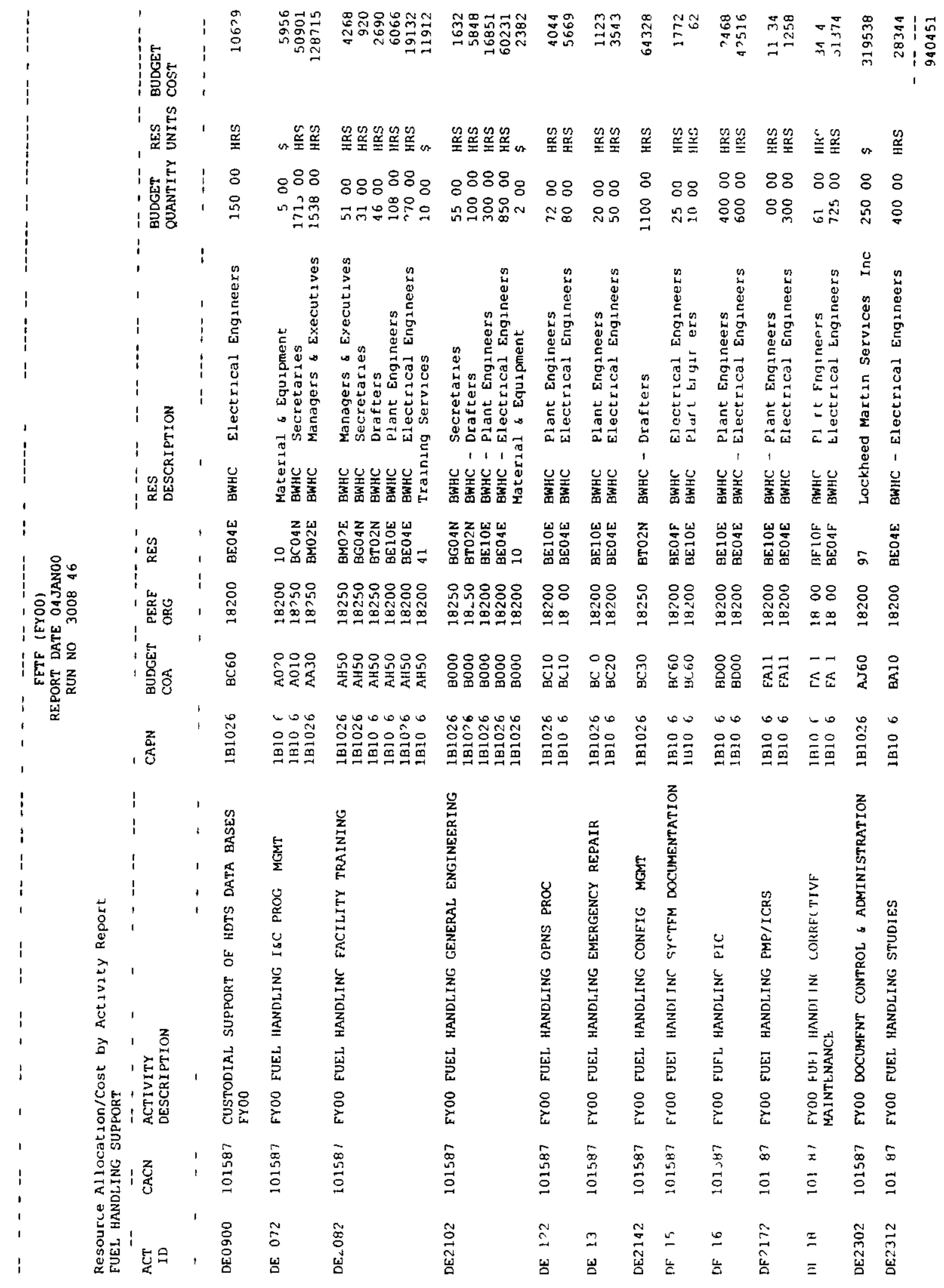




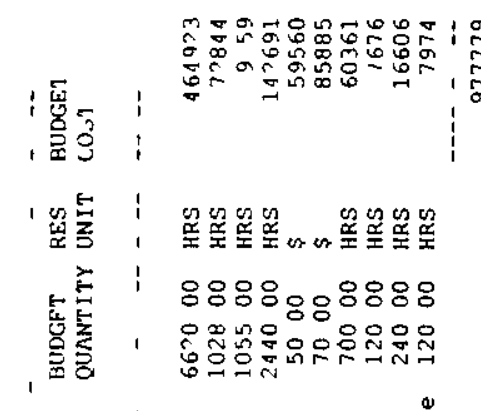

no

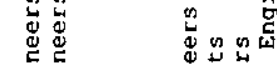

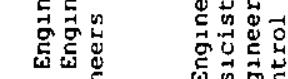

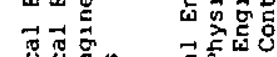

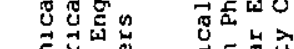

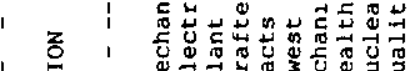

|

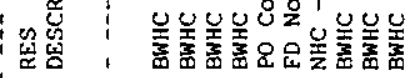

级

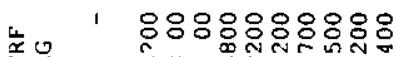

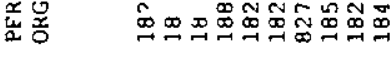

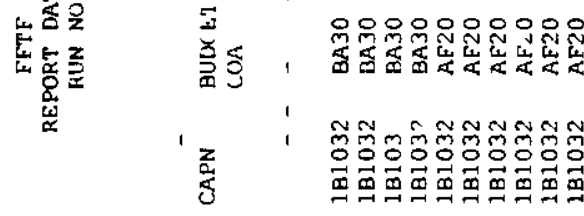

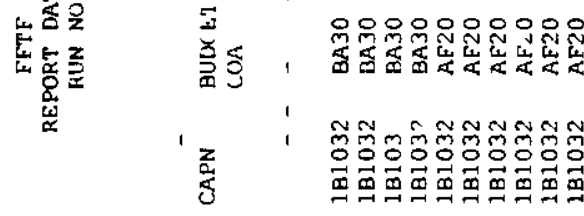

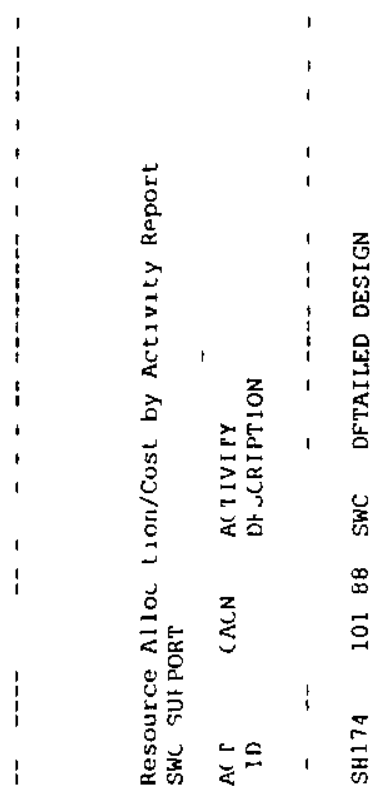




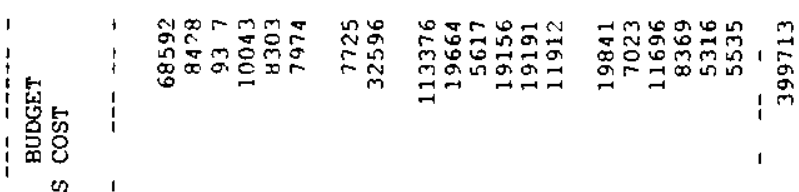

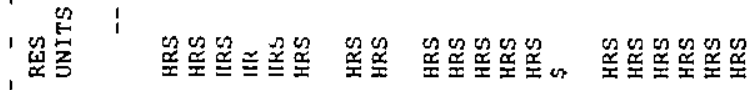

离 | 888898 88 88888. 888880

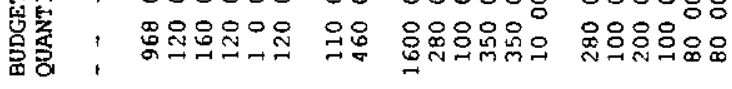

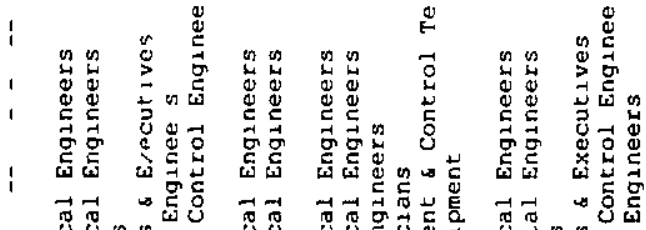

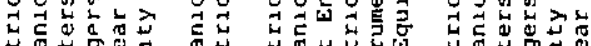

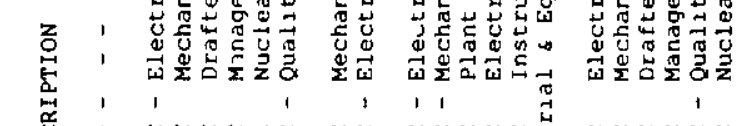

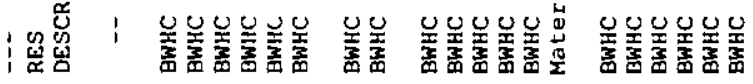

|

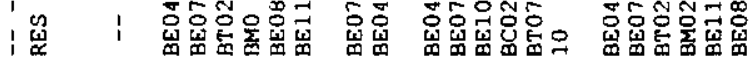

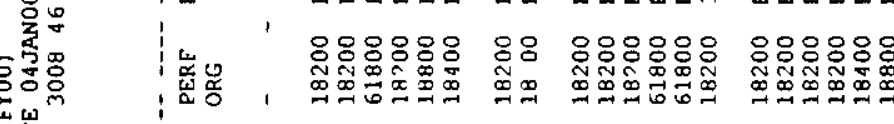

氙㞾

密它要

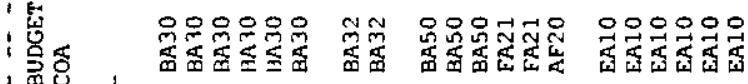

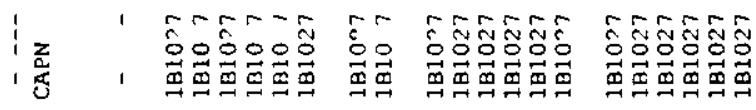

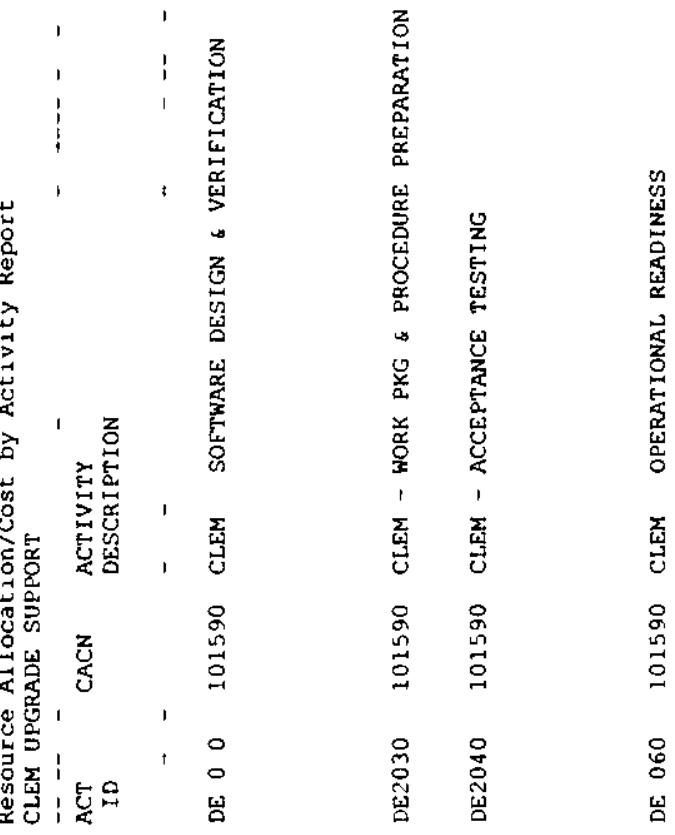




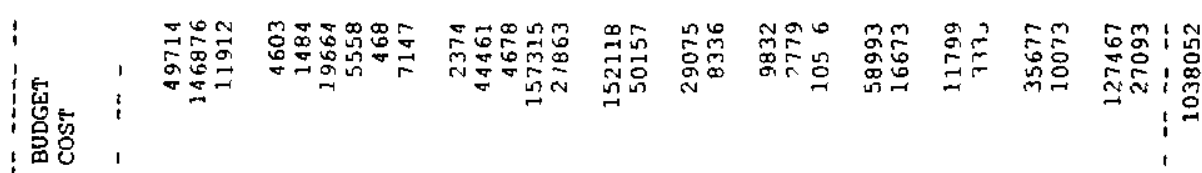

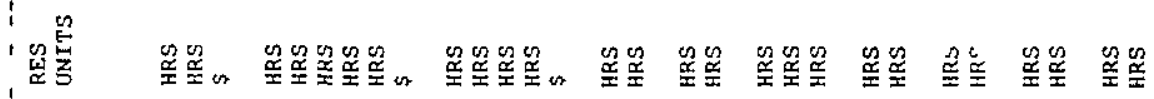

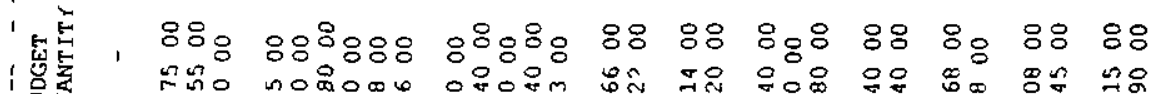

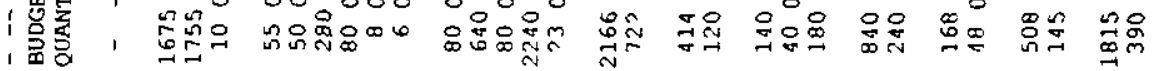

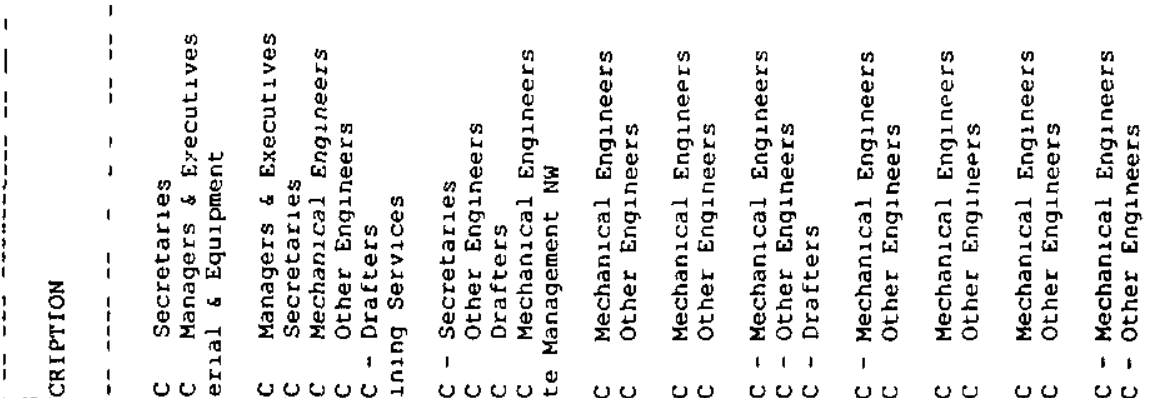

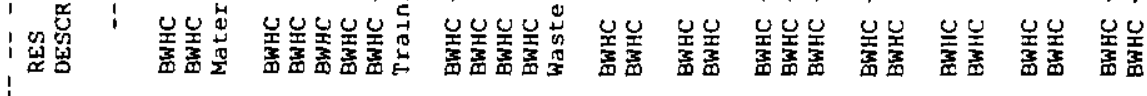

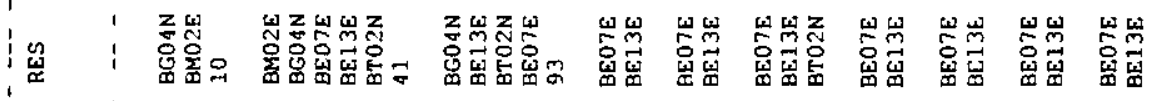

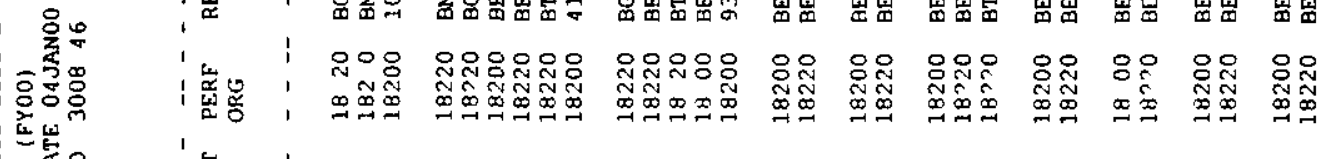

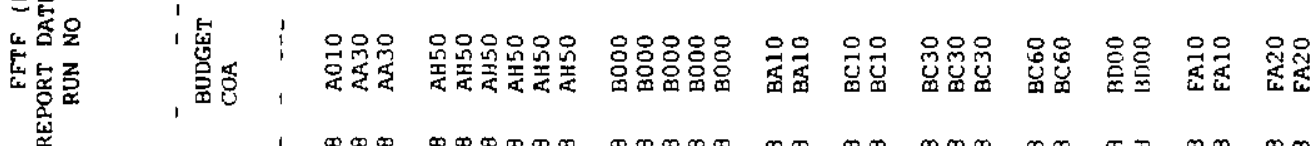

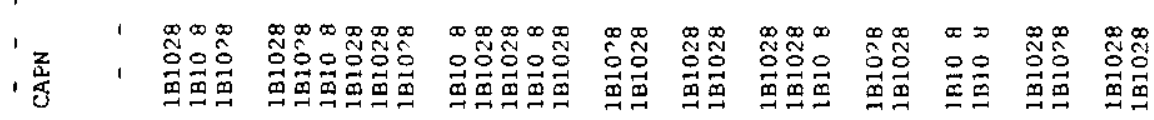

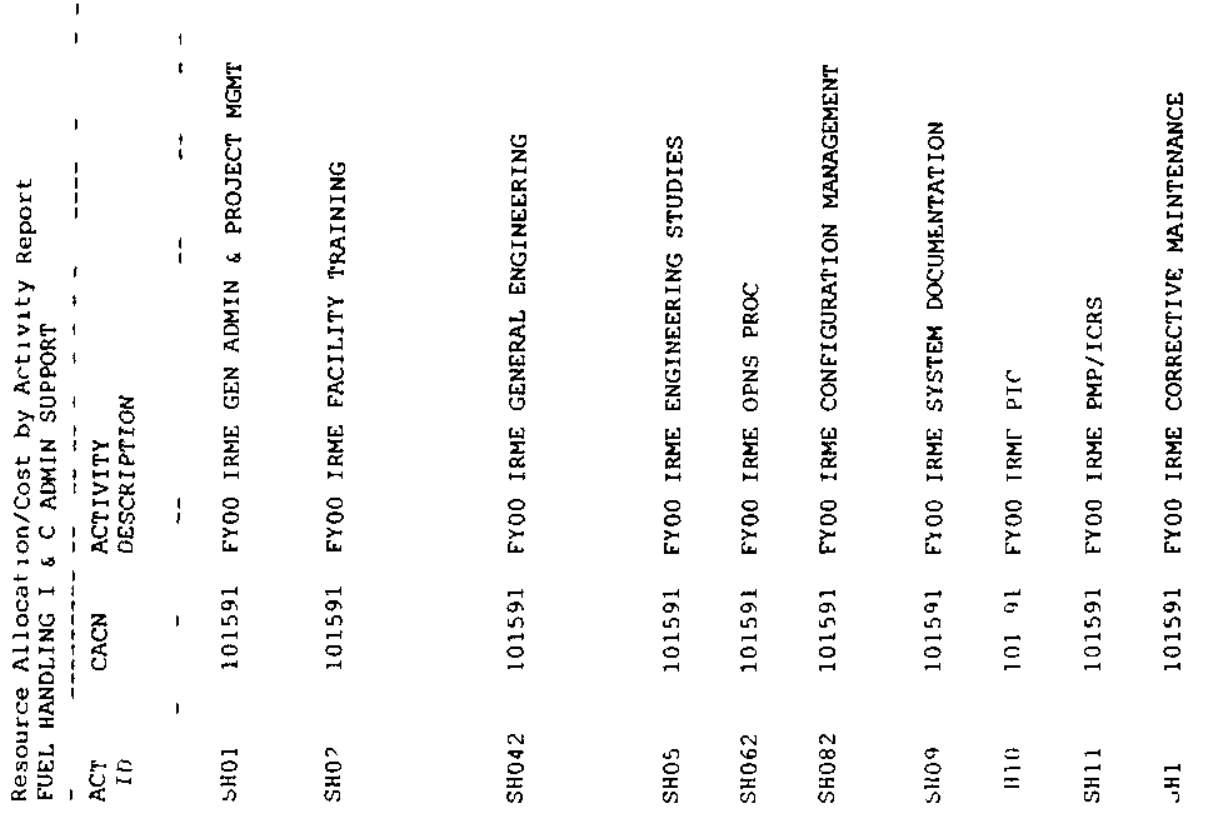




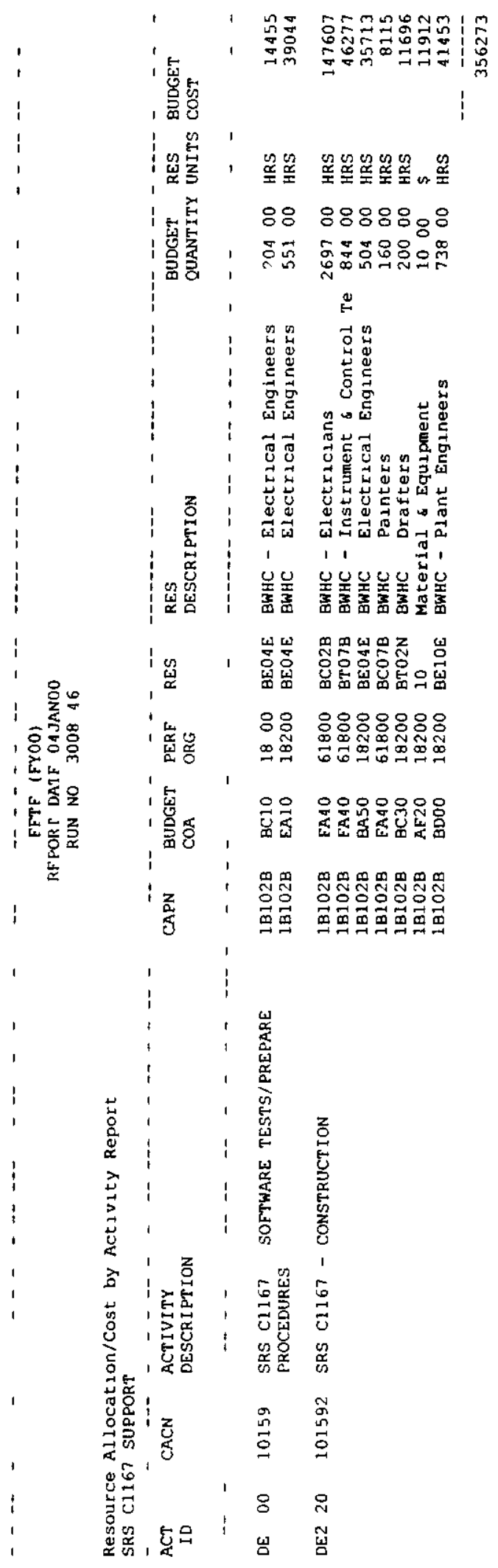


HNF SD FF SSP 050

Rev 8 Page 193
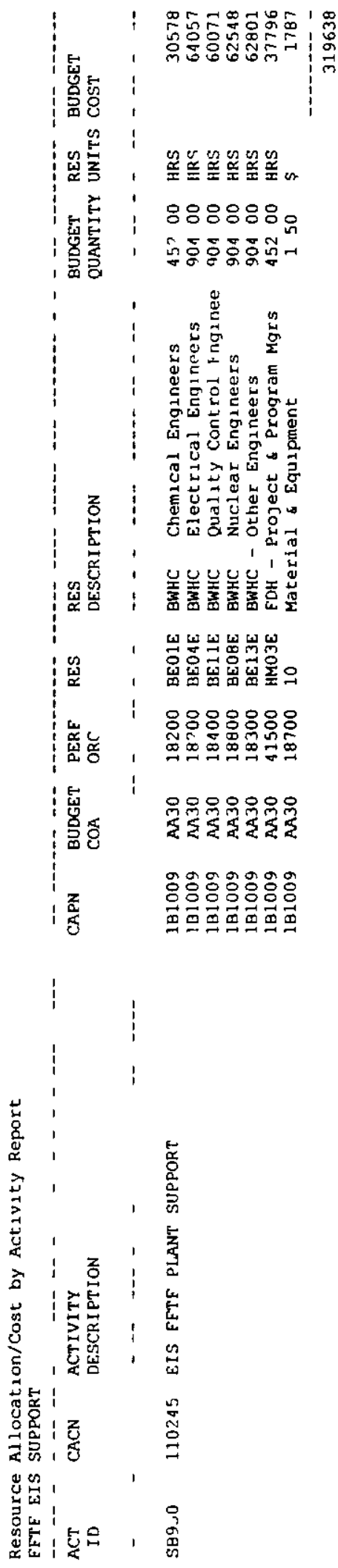


\section{HNF SD FF-SSP 050}

Rev 8 Page 194

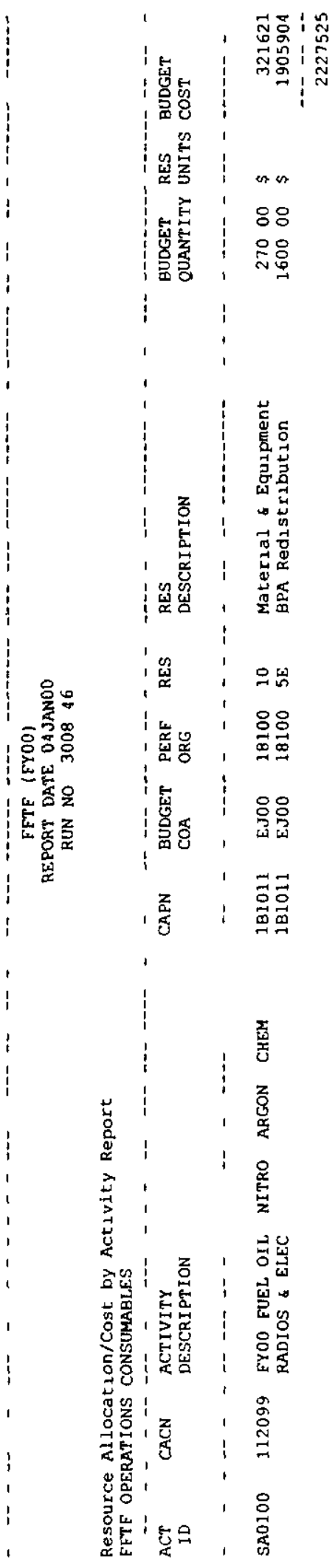




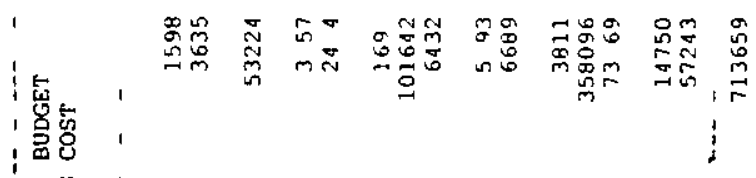

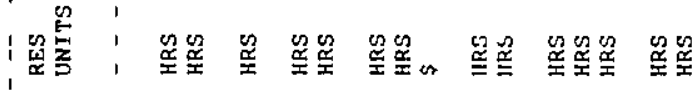

| 氙:

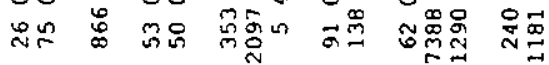

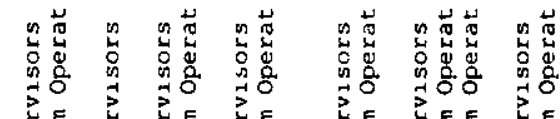

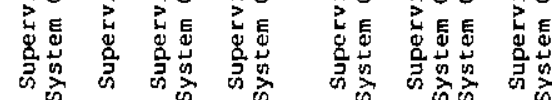

on

1

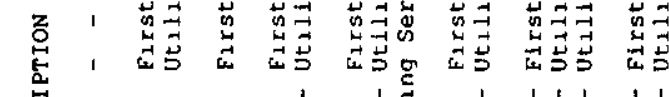

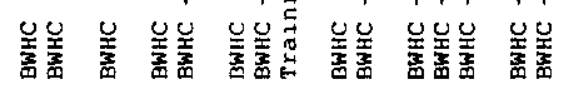

崩置

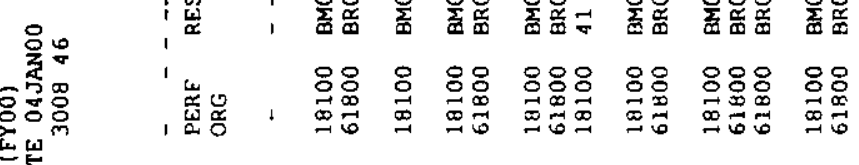

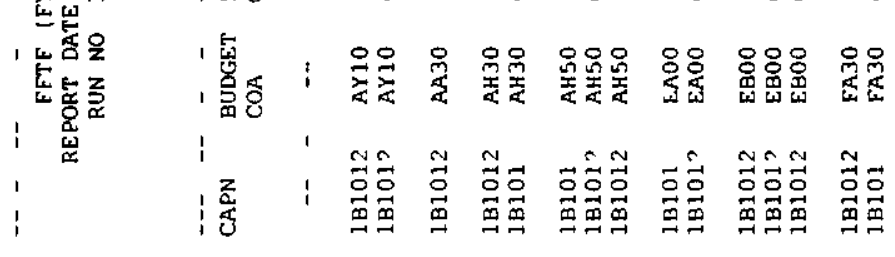

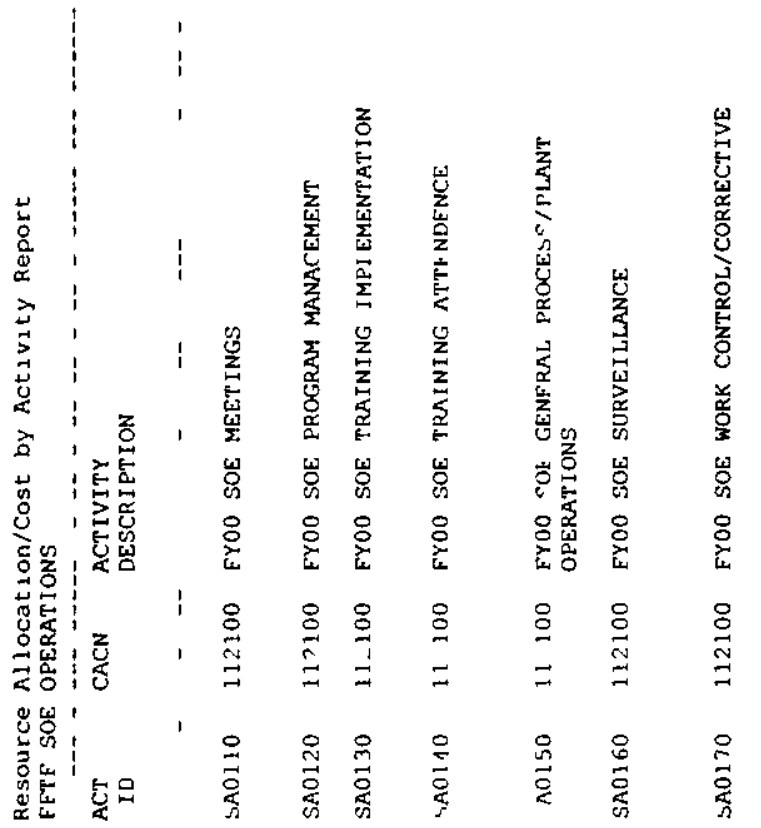




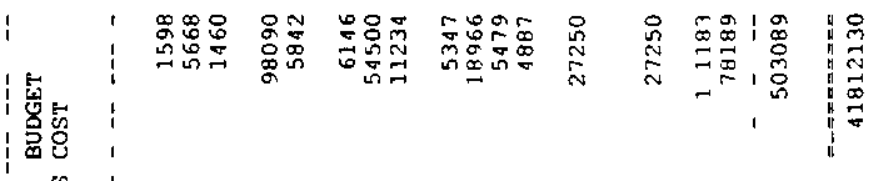

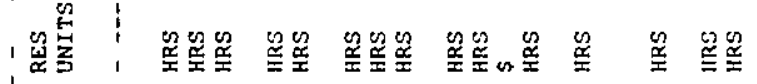

|

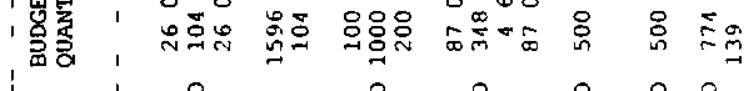

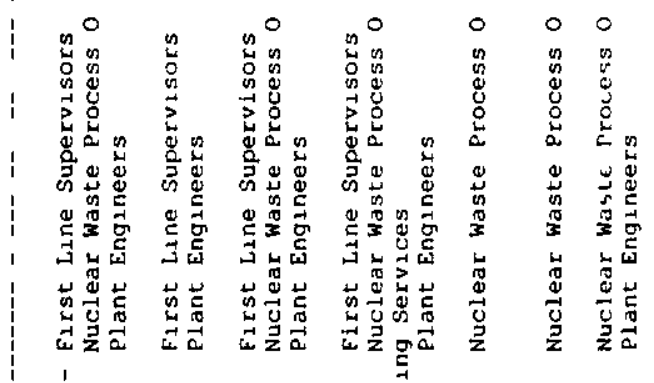

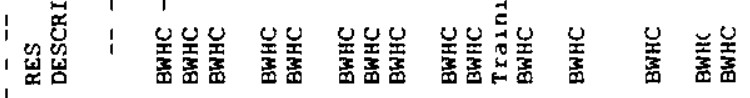

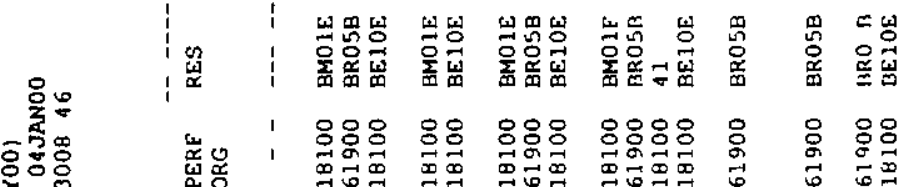

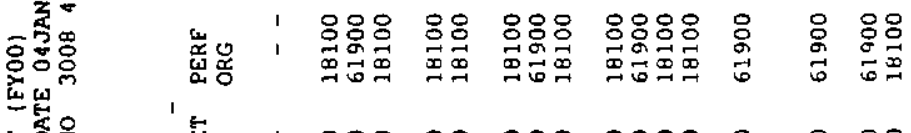

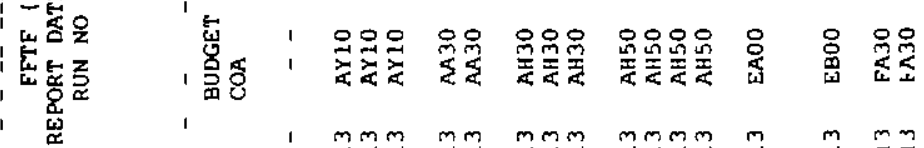

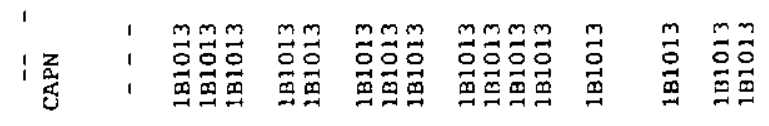

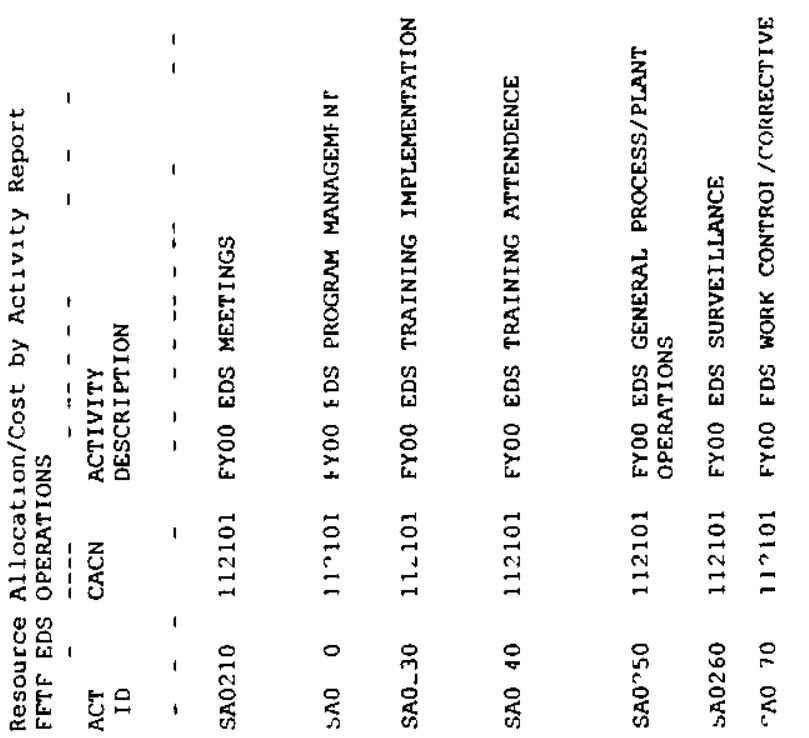

